Historic, Archive Document

Do not assume content reflects current scientific knowledge, policies, or practices. 

62,17

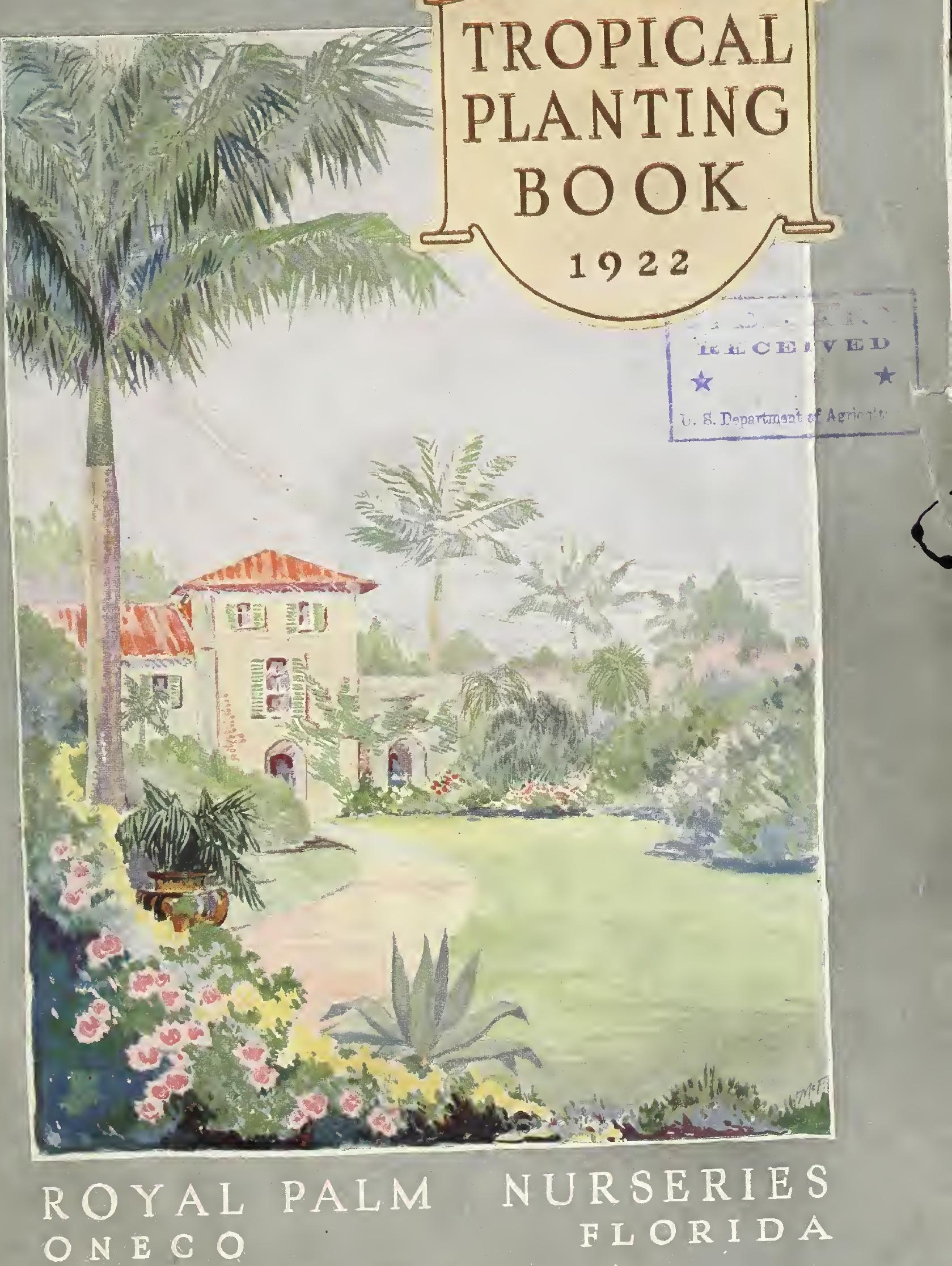




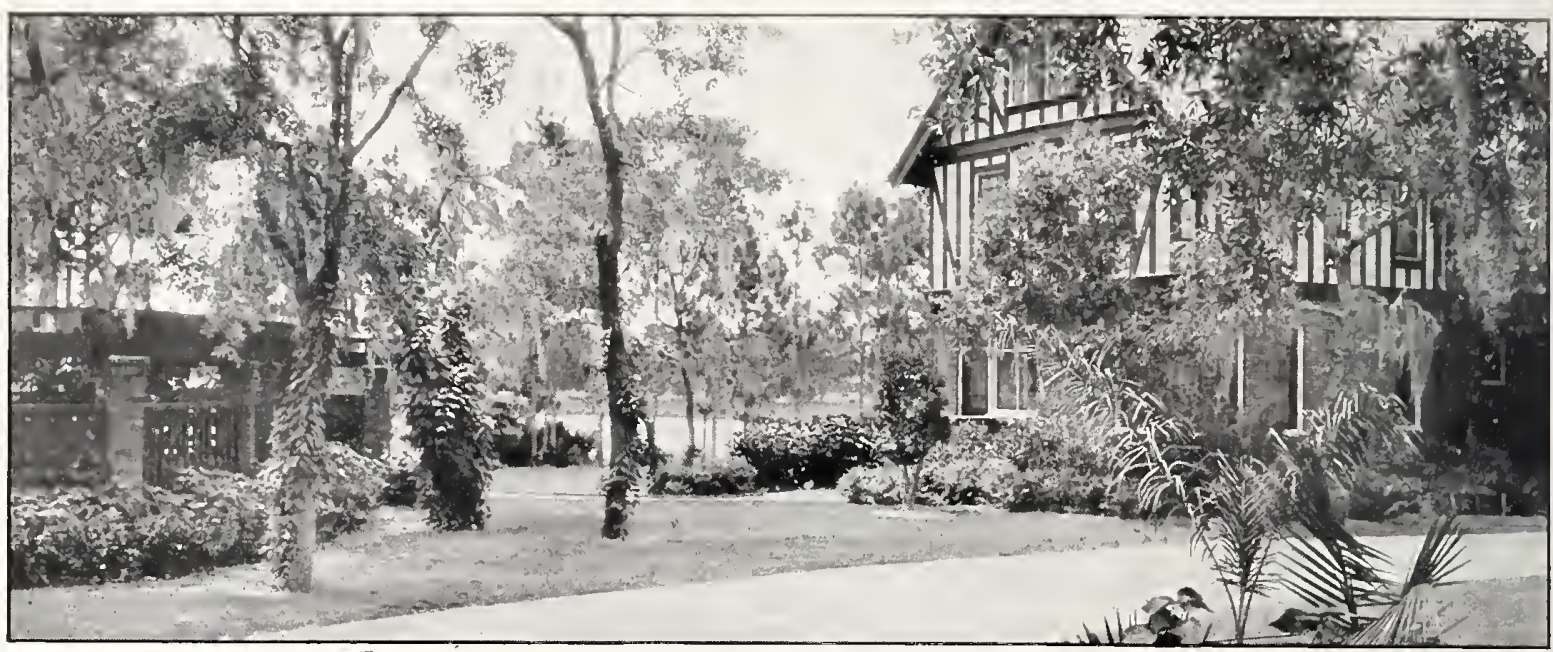

A service entrance attractively handled

\section{Business Rules}

All prices in this catalogue are NET delivered to railway agent, packing free, purchaser to pay cost of transportation. If there is no agent at point of destination, requiring prepayment of express charges, or when the relatively small size of the order makes parcel post service more practicable, or when shipping to foreign countries, the following charges for such prepayment are made:

For prepayment by mail or express in Florida, customers must add 10 per cent to the total value of the plants. Outside of Florida and east of the Mississippi River add 15 per cent. West of the Mississippi River add 20 per cent.

To all foreign countries, add 30 per cent.

We cannot fill orders amounting to less than $\$ 1$. Such orders are a positive loss to us. Should you want a special plant amounting to less than that, add 25 cents, plus observation of rules above.

TERMS. Cash with order. Remit in any safe way. Postoffice money order on Oneco, bank draft, express order or currency by registered mail. Foreigners may remit by International Postoffice Order on Bradentown, Fla., or by bank exchange.

In applying prices, 5 of a variety will be sold at the 10 rate, 40 at the 100 rate, and 400 at the 1,000 rate.

GUARANTEEING PLANTS. This is not done by any reputable nurseryman unless he charges prices sufficiently high to more than offset any possible loss. When good stock is received in good condition, no difficulty should be experienced in getting it to grow and do well unless the conditions are not favorable, and it is obviously not up to the nurseryman to assume responsibility for cultural failures.

And it would also hardly be fair to the customer who takes proper care of stock and who understands the requirements of different plants, to charge him a price higher than normal merely to protect the nurseryman from losses incurred by guaranteeing stock to careless, incompetent, or unscrupulous persons. The logic of this should appeal to any sound business judgment.
OUR RESPONSIBILITY. While we exercise the greatest care to have our plants true to label, and hold ourselves prepared, on proper proof, to replace any that may prove otherwise, we do not give a warranty, expressed or implied, and in case of error on our part, it is mutually agrecd between the purchaser and ourselves that we shall not at any time be held responsible for a greater amount than was paid for them.

While our responsibility for safety of plants ceases after delivery of the goods to carrier, in so far as liability for damage is concerned, still we feel a personal concern for the interests of our customers and are anxious that their rights should be protected. In the case of shipments by express or freight, from which forms of service collection of damage claims is possible, we will guarantee safe delivery of all nursery stock, or to collect any just claim provided consignee has the agent at destination endorse the extent of damage or loss on freight or express receipt. The same provision applies to overcharge; we keep accurate record of all shipments and have express tariff on file in office, and if anyone suspects an overcharge, we will investigate same when they send agent's receipt and secure refund if such has been the case.

FILLING ORDERS. AIl orders are filled promptly, the majority on the day of their receipt. We ship with absolute safety to all parts of the world by parcel post, express, and freight. We exercisc our best judgment when forwarding stock, whether by express or freight - in the former case using especially thin material-working for the best interest of each customer as to safety of delivery and least cost.

SUBSTITUTION. In ordering please state whether substitution will be permitted, as we fcel at liberty, when no instructions accompany the order, to replace with other sorts as nearly similar as possible.

THIS PRESENT CATALOGUE abrogates all previous terms, conditions and prices. Dealers desiring to buy in quantity will be given special prices. Annual catalogue, usually ready in October, covers prices from November 1 to October 31.

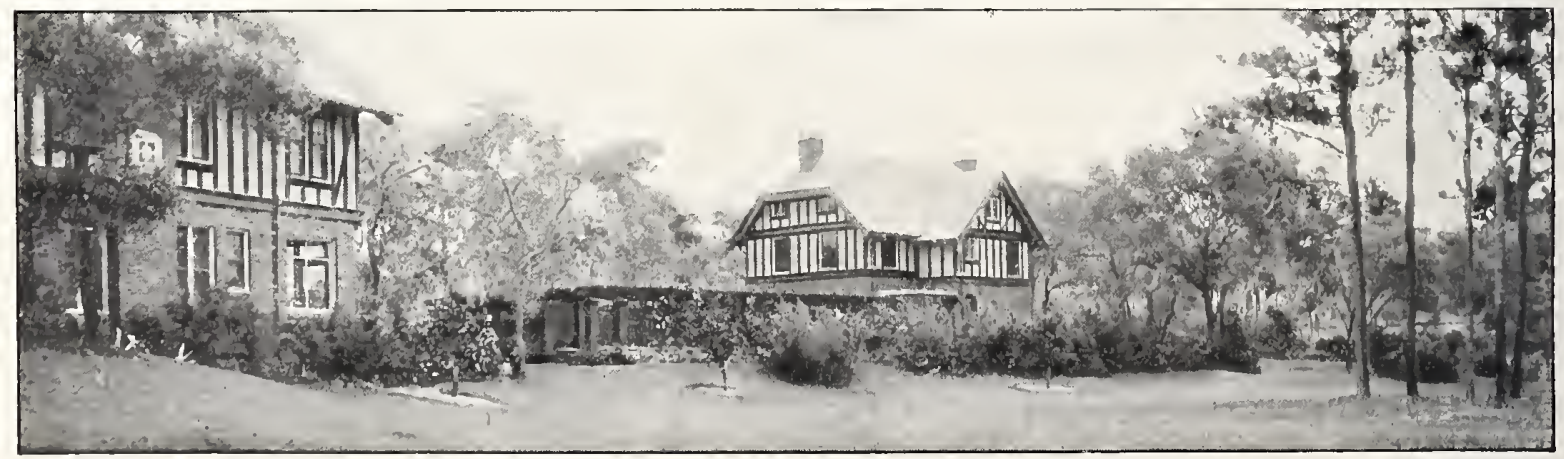

Screening the garage and lending an atmosphere of distance 


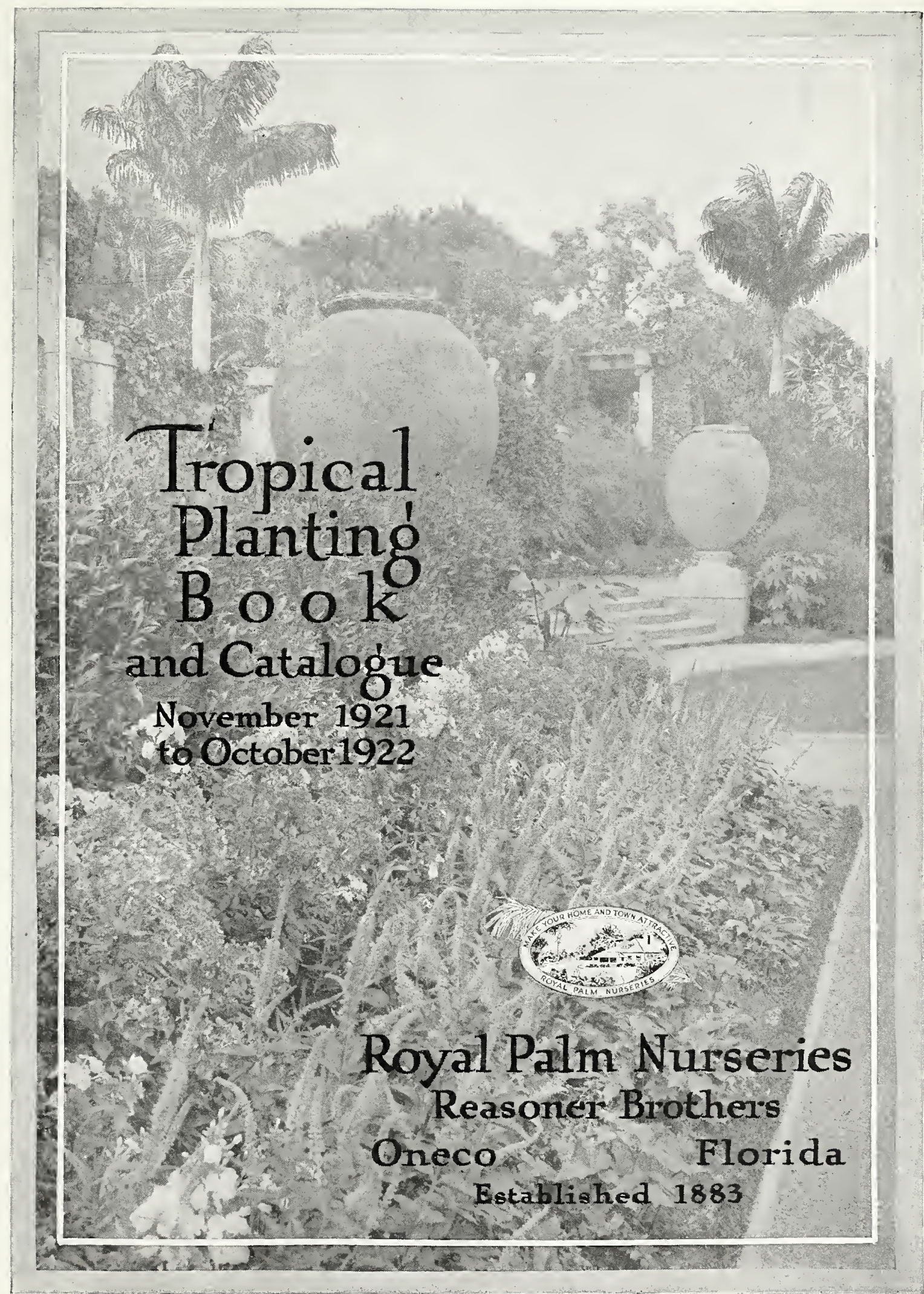




\section{The Reformation of Mr. Billings}

W

ELL within the circle of wclcome shade cast by a thrifty Laurel Oak that graced the parkway by the entrance gate to his roomy home-grounds stood Hiram Billings, promincnt in the commercial, social, and historical life of Pinctum, a flourishing little peninsular city. He had Iong time since laid aside his shell-rimmed spcctacles becausc of the impossibility of secing through their perspiration-clouded lenses, and he now leaned the weight of his ample bulk on the uncomplaining handle of a large hoe while he wiped away the seemingly endless streams that courscd down his dceply flushed face.

"Morning, Miss Emily," he nodded to the pleasant-faced little lady whose daily duty it was to minister to the intellectual welfare of the youth of the town, not to mention giving them mueh of the training they might well have received at homc.

"Good morning, Mr. Billings. At your usual avocation, I see," she added, not without a trace of mischief in her eyes. "Your garden must be a real satisfaction to you, the way you work over it."

“WeII, now, Miss Emily, it is, and it isn't. I used to fcel that I had as good-looking a yard as anyone could have; and it does look good now, too. Look at that grass; did you cver sce anything niccr?"

"Frankly, I never did-it is as good as any in Pinctum. Still"- and again there was that ghost of a smile that failed to make itself known- "your beds of flowers don't seem to be just what they might be."

The big man replied: "WcIl, that's what's worrying me. Sce that big round bed in

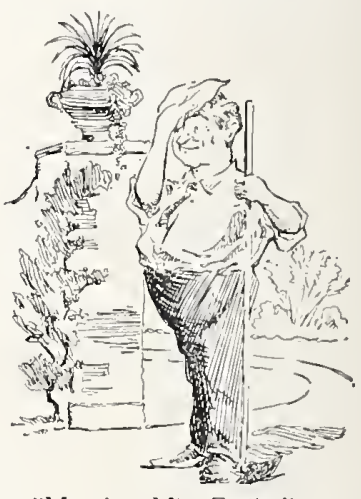

"Morning, Miss Emily." front of the porch? The Elephant's Ears and Cannas did mighty well, but the border of Violets and Pansies around the cdge don't look like much. I wish now I'd put something clsc therc."

Thus encouraged, the young woman ventured further: "Do you know, Mr. Billings, I have becn thinking about your yard a good deal bccause I pass it as I go to school evcry day, and it occurred to me a number of times that if you would get a landscape man to lay it out for you, you would get much better results. Look at what a splendid place Mr. Anderson has, on the other side of the lake."

This brought a vigorous come-back, as Mr. Billings said: "Landscape man! Fiddlesticks, Miss Emily! In the first place, I'm no millionaire, to have a place like his. Look at the money spent on that property. 'Most anyone could have a fine place spending that much. Now just take the Jones' place, over the other side of town. There's a specimen of what a landscape man will do for a small property. That was done by the same man from the same frrm that handled the Anderson place, and just look at it! I'm no judge of this high-brow landscape work, but those who pretend to know something about it say the Jones' property is a mess. I know I don't like it."

The smile that had becn trying to contain itsclf now brokc into a pleasant littlc laugh as Miss Bright nodded approval. "Yes, I quite agrec with you; but as the Grapenuts advertisements say, 'There's a reason.' I happen to know about that case because I had something to do with getting Mrs. Joncs to consider having the place laid out.

"If you will remember, that was planted in the fall while Mrs. Joncs was away, and when she came back and saw the grounds she was all upset because things did not look to suit her. Of course there had been no growing season; the plants were aIl small and had had no chance to show what they eould do. Without any opportunity for growth, it was impossible for the place to present the effect the landscape man had in mind.

"WcIl, what did she do? Did she say that, while disappointed, she would give the planting a fair show by waiting a year or two for the plants to attain some size and the plan to develop cxpression? No, she pitched right

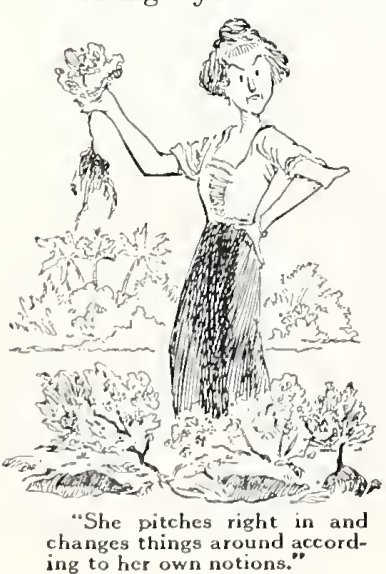
in to change things around according to her own notions, regardless of any definite plan. Hcdges were taken out herc, plants moved around therc, garden construction work was scparated from the supporting lines of shrubbery, and bcfore anyone could rcalizc it, the place was a hopeless muddle.

"Dcaling with pcople like that is cnough to discourage any landscape artist. To be sure, they arc not infallible, but if they don't know what to do, how is any untrained person to know?

"You admit that Mr. Anderson's place looks well. What about old Miss Livingston's home, and Dr. Allsobrook's, and most of the other successful home plantings-all the result of a good plan that has had time to devclop. The trouble is, Mr. Billings, we don't have enough patience; we all want plants to grow up like Eucalyptus trees, or like those mythical shrubs of the Oricnt that rise under the magician's wand!"

Mr. Billings understood plain English, and could put two and two together. His cyes werc bright as he ejaculatcd, "Jiminy crickets, Miss Emily, where did you get all that? You talk just like the Garden Magazine!"

Thus cncouraged, the school-teacher proeceded to follow up her advantage. 


\section{ROYAL PALM NURSERIES}

"Why, it's easy enough when once you get the real idea of planting. You may go along year after year just blind to the meaning of it all when suddenly something, or somebody, makes it all so clear to you that it is like reading an open book."

" 'Pears to me like it was some-body in this case," slyly hinted Mr. Billings.

With slightly heightened color the young woman replied: "Well, I'II tell you frankly that I woke up to what gardening meant when I heard a talk to the Women's Club over at Oak Terrace not Iong ago, given by this same Iandscape inan. One thought I remembered particularly, because it made me see the great meaning behind aIl landscape art,-for it is an art just as much as painting on canvas. This was-'In the planning of grounds the plants should be considered subjectively and not objectively.' As he explained this hard saying, he made it all clear to me. I can't repeat his exact words, but this was the idea.

"Ordinarily, when John Doe undertakes to improve his grounds, he reasons this way: 'I want to fix up my place a little, so I guess I will plant a couple of Phonix palms in those grass plots in front of the house. That will be a good place for them, because it is prominent. Everyone will see them, and I can enjoy them too.' Now you see John Doe has been reasoning from the objective standpoint. That is, he has just been considering what the plant would look like; he has been making it the object in his planning ideas.

"Instearl of that, he might better have looked at it this way: 'I want to have my grounds good to look at for the home folks, and to make an attractive picture so that all who pass may also enjoy looking at the place. To do this, I will first have to supplement the architecture of the house by making it a part of the picture, so I will plant some attractive small-leaved shrubs around it to best advantage. Then, instead of breaking

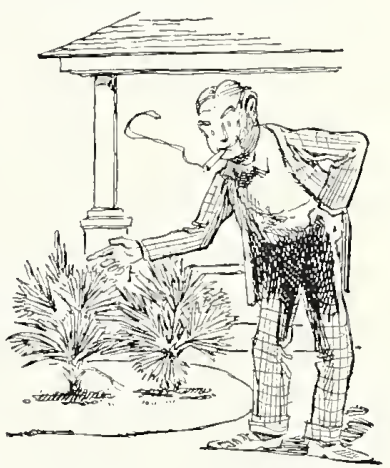

"John Doe has been reasoning from the objective standpoint." up the picture by planting paIms in front of the house, I'll put a big-growing Date Palm just off this corner on the north, and on the south a good shade tree to screen the porch from the afternoon sun. This will frame the house in tropical verdure and also provide an interesting sky-line.

“ 'Then I'Il screen out that unsightly view over there by providing a heavy mass planting around the property

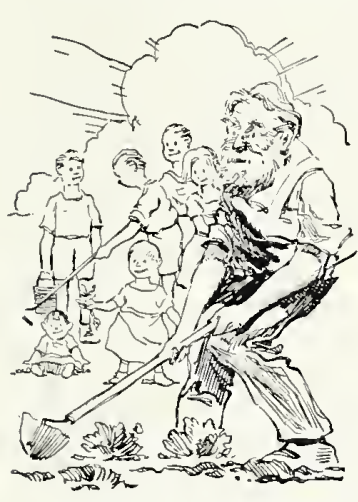

"Miss Emily, my grandfather, by gardening, made living and raised a family." lines to give reasonable privacy to this cozy picture-home.' And so he would have gone on, all the while keeping clearly in mind one central idea-the bome and the picture it would be as the object and always remembering that the plant materials he would use were to be merely the subjects that were to be used to accomplish that result. Don't you see?"

It must be confessed that Mr. Billings did not "see" just what she was driving at, but he caught something of her enthusiasm and enough of the general sense of her meaning to be half persuaded to follow her advice. But it was not his disposition to give in readily.

"Miss Emily, my grandfather came here from the old country, and by gardening made his living for a good many years and raised a family - he was about as good a gardener as the old country ever had, I guess. And I've been studying this business of flowers and the like myself while puttering around here in my own garden, and I'm just foolish enough to think that I can work out my little problems about as weIl as any landscape man."

The smiling face of the school-teacher became suddenly serious. "Oh, I almost forgot something, Mr. Billings. Excuse my changing the subject, but we are going to hold a fair, and $\mathrm{I}$ am asking everyone intcrested in the school, especially those whose children attend, to donate something for the sale. Now I was thinking that perhaps you would paint a picture for us that we could sell for a nice little sum. We need a new piano so much."

The genial merchant looked nonplussed. “But I can't paint pictures, Miss Emilynothing that would do to sell."

"Oh, I thought you could-didn't you tell me once that your mother used to make you color pictures? And I know you used to paint houses, and understand all about mixing. paints and that sort of thing."

"But great snakes, Miss Emily, I never had any training as-_"

Then Mr. Billings woke up-and Miss Bright discreetly hastened off down the street.

An hour later the portly form of Mr. Billings could be seen turning into the entrance-way of John Hitching's real estate office.

"Hello, John," he greeted the busy little man at the first desk. "Sorry to bother you, but you know all about the plant business here in Florida. I've been thinking some lately of getting heIp in laying out my grounds at the house, and I thought perhaps you could teIl me the address of Reasoner Brothers."

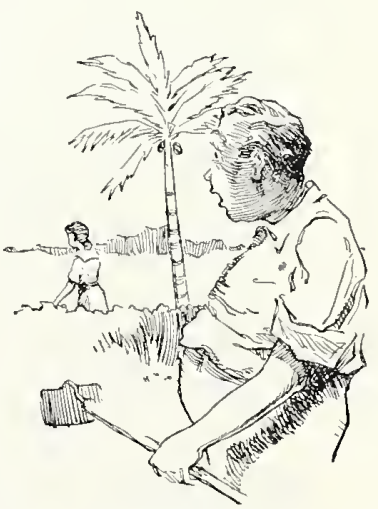

Then Mr. Billings woke up. and Miss Bright discreetly hastened off down the street. 
Hiram Billings lives and brcathes today in every city and town in the state; no doubt you have recognized him in scores of your acquaintances. But many Hiram Billings' have reformed, and have permitted us to help them solve their problems bccause they have learncd to appreciate the trcmendous value of our organization, the oldest and largest of its kind in the state. Not only can we improve the layout of public and private grounds both in appearance and usability, but we can save planters much that would otherwise be real loss" in the sclection of matcrials to meet the demands of individual soils and locations. Like most states of large size and long distances north and south, the striking differcnces in soil and climatic conditions are grcat, and it is especially important to have a thorough understanding of and experience with this and rclatcd mattcrs in determining what plants to use for sccuring the desired effect. For this reason our service is doubly valuable and important. We not only know how to plant pictures that live, but we know what plants will thrive as the elements of those pictures in every part of our sunny state. We know, too, and have provided, the unusual and uncommon plants and trees, to give distinction and individuality, and secure the lovely tropical effects that belong to the Florida radius. We have the plants, the knowledge, the experience; and, best of all, we love the land we are helping to develop into beauty and fruitfulness.-REASONER Brothers.

TERMS. It is impossible to furnish so-called "stock plans" for any given place, as the conditions of each place are different and require individual treatment. It is also difficult to give any adequate idea of the cost of planning any grounds without understanding the conditions involved, and our experience shows that the following method is most satisfactory:

Take a sheet of paper, any convenient size, and rule into squares an inch apart each way. Then sketch in your property to scale; if it is, say, 180 feet long and the paper 11 inches, make the scale 20 feet to the inch. Note on this shcet, house, garage, and any other outbuildings, fences, drives, walks, trees, or other permanent plantings already on grounds, directions from house of chief views, both the desirable and objectionable ones, if any. Mail this to us with letter of explanation and after carefully considering the problem we will write vou regarding it and quote you on the cost of planning etc. We urge that you do this, as it may mean the difference between the success or failure of your planting.

PLANTING SERVICE. If you wish it, we can take complete charge of the planting, as well as the planning, of your grounds. Competent planting foremen assure the greatest measure of success in this class of work. Where the planting is sufficiently extensive to justify it, this service is a real saving to the property owner and we arc glad to furnish the supervision when desired. If interested we will be glad to have you write us further regarding the matter.

CIVIC IMPROVEMENTS AND REAL ESTATE DEVELOPMENTS. In common with the increased interest in the ornamental improvements of private grounds has come a dceper realization of the necessity for street trees, street parking, city parks, and playgrounds, and this necessitates

expert advice and assistance. This service we are in position to furnish, and we invite town councils, boards of trade, women's clubs, real estate organizations, etc., to consult with us along these lines. It is very much to be regretted that the average Florida town does not present a better appearance to the visitor to the state and more comforts and conveniences in the matter of shady, well-planted streets, parks and playgrounds for the permanent resident. The only way to overcome the absence of these things is by taking vigorous and concerted action. Not only can results be accomplished that will rival the best that has been done in the North and in Europe, but also the mere fact of the splendid opportunities we have for obtaining tropical effects because of our favored geographical location offers wonderful possibilities for results unique and altogether different from anything else in the country. Property owners of the state will be very remiss in their obligations to themselves, and to the people at Iarge, if they neglect to avail themselves of these advantages.

HOME BUILDING SUGGESTIONS. Many long years of residence in Florida have brought to our attention and demonstrated to us the value of many important features regarding types of architecture and details of planning the home building itself, and we will be glad to coöperate with you in this connection, to the end that you may have greater comfort, more convenience, and better appearance in your home.

FREE SERVICE FEATURE. There are so many minor problems arising from time to time in respect to planting and the care of grounds that we urge our customers to write us regarding them at any time and we will gladly help in solving them. The success of your planting is a matter of genuine concern to us. Address Service Department.

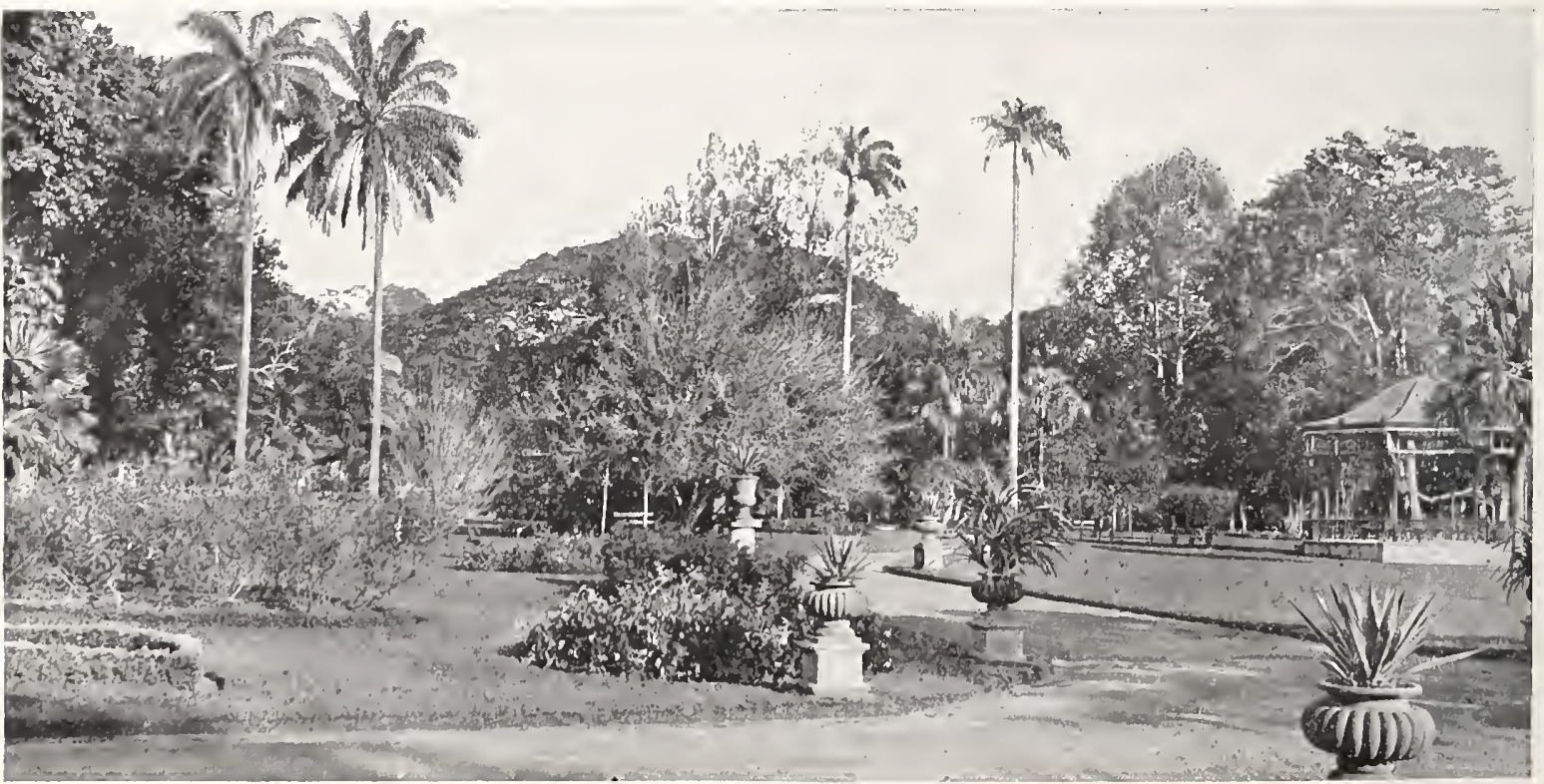

West Indian Tropical Garden 


\section{Planting and Potting Suggestions}

$\mathrm{P}$ REPARATION FOR PLANTING.--Newly cleared land, especially in Florida, is "sour" (acid) to a grcater or less degree. This may be corrected, if not too sour, by cultivation, opening up the soil and allowing it to become thoroughly ac̈ratcd before planting. Otherwise, lime should be applied in quantity, depending upon the degree of acidity. No specific amounts can be prescribed because of wide range of variation in soils. In cases where the planter is in doubt, the matter should be taken up with the state chemist.

In making holes in which to sct the individual plants, remember that the larger the bctter, two to threc feet across being small enough for ordinary pot plants, though, of course, smaller holes will do if the plants are properly set out and otherwisc carcd for. For larger specimens, make the holes proportionately larger. When planting, fill the hoIc with top-soil in which is incorporated from several shovelfuls to a wheelbarrow load of well-rotted manurc, past the burning stage, depending upon plant, soil conditions, etc.

Florida soils are naturally deficient in humus (decomposed organic matter) and for that reason manure or some other form of humus is prefcrable where it can be obtained. Experience shows that manure and water will producc splcndid results on the poorest soils. In the deep sandy soils of South Ccntral Florida, on the so-called "sand hills," this has been demonstrated by remarkably successful plantings. In addition to humus as fertilizer, blood-and-bone, tankage and other fertilizers are valuable organic forms that are readily available.

ARRIVAL OF PLANTS. Plants should be removed from the package or box as soon as possible after reaching destination. Frequently, however, it is impossible to plant them out at once, in which case see that roots are wet, then stand the rolls of plants around in cool, shady places; seeing that they do not suffer for want of water. They can remain this way several days without injury. Large trees and shrubs from open ground may be simply "heeled-in" (planted in trenches) on the shady side of a building, the roots well watered, and, if not set permanently for a week afterward, they will be all the better for it. Should any of the plants appear wilted, they should be placed in luke-warm water, with the packing moss about their roots, and in half an hour they will be ready to pot. This treatment will renew their vigor whether actually wilted or not.

SETTING. Assuming that the soil has been put in proper condition, the plants and trees can be set in their places at once. If the plants are from pots, set them considerably deeper than they were in the pot, the distance depending on size of plant, etc. Set without disturbing the roots-never try to straighten out the roots of pot-grown plants. Field plants, when dug, lose the larger proportion of their feeding roots and have to be cut back proportionately, and, in some cases, planted several inches deeper than they stood in the nursery rows. (Exception is here taken especially to citrus stock.) The roots should be trimmed with a sharp knife, and, when planted, allowed plenty of room to assume a natural position. Pack the soil well around the roots with hands and feet - this is very important. Use plenty of water. Always mulch the ground around with grass, straw, or similar materials. Some more tender plants require shade for some time and all plants are better for shade for the first few days. BUT THIS ABOVE ALL: See that they never lack for water until established.

POTTING. While plants are small, use pots one size larger than they were removed from. As they fill up the pots with roots they should be potted on into sizes next larger. When small, it is necessary only to place a piece of broken pot over the hole in the bottom, but when the pots run up to 5- and 6-inch sizes and larger, they should have several pieces of charcoal or other coarse drainage material. To prevent soil from entirely filling this up, place a piece of well-rotted sod over the drainage material. Lack of proper drainage prevents free movement of water through the soil, which soon becomes sour; the roots die back and the plant suffers. Fill the pot to about half an inch or more of top with ball of roots and potting soil, the latter composed of good loam, sand, clay, if obtainable, and well-rotted manure, past the "burning" stage, with a small amount of chemical fertilizer such as comes prepared for the purpose. Place the plants in a sheltered position where they will not be exposed to wind and sun until they show signs of recuperation.
WATERING. This is one of the most important things in the successful cultivation of all plants. During the growing season they should have enough water to keep the soil moist to the bottom of the pot, but never in a soggy state. Excessive watering is worse than not quite enough; judgment must be exercised in this matter, but never just wet the soil on top. It is a good idea to place the pots in a tub of water until all air is driven out of the soil, then allow the excess water to drain off completely before replacing in jardiniere. Do this once every ten days or so, in addition to the regular watering. But NEVER water plants while they are standing in jardinieres-this allows water to accumulate as the surplus drains out of the pot, keeping the soil soggy and sour and has the same result, only to greater degree, as poor drainage.

FROST PROTECTION. All parts of Florida are subject to frost to a greater or less degree - there is no such thing as "frost-line." In freezing weather, however, there are a number of ways in which tender plants may be more or less effectively protected. One of these is by means of raising the temperature a few degrees, as with smudge fires, "blanketing," etc. The old "light-wood," pitch, and other methods of creating a blanket of smoke and warm air are giving way to the cleaner, more convenient method of oil-pots. Sheds are used, sometimes merely overhead slats, like those used for pineapples, and at other times solid wall enclosures. Considerable expense is attached to all these methods and they are only advisable when plants are extremely susceptible to injury from cold. As a matter of fact, in frosts and light freezes it is not so much the reduced temperature that does the injury as it is the effect of the early morning sun's rays striking the plant after a freezing night's temperature. If the plants can warm up gradually they will not suffer. To effect this, various means are uscd. One of the commonest among truckers, where water is available, is to spray water over the plants for some time after sunrise. Tender trees on the west side of a building or other protection never suffer like those exposed to the early sun, though the west side is actually the coldest. The same effect may be secured with plants in the open by standing boughs of trees, cane, or corn stalks, etc., in a tent-like formation all around the trees. Pine boughs are especially valuable for this as their needles remain on throughout the winter. While trees are very small a light framework of stakes, etc., covered with cloth, paper, or burlap, will afford ample protection, and in cases of very severe cold nights a lamp can be placed underneath. Do not forget to provide ventilation. In the case of budded or grafted trees, banking above the union is advisable, as in the event of the top being frozen down, enough of the finer variety is left to give a new top the following year. In any event do not cut back trees or plants immediately after a freeze; wait several days to see just how much they are injured.

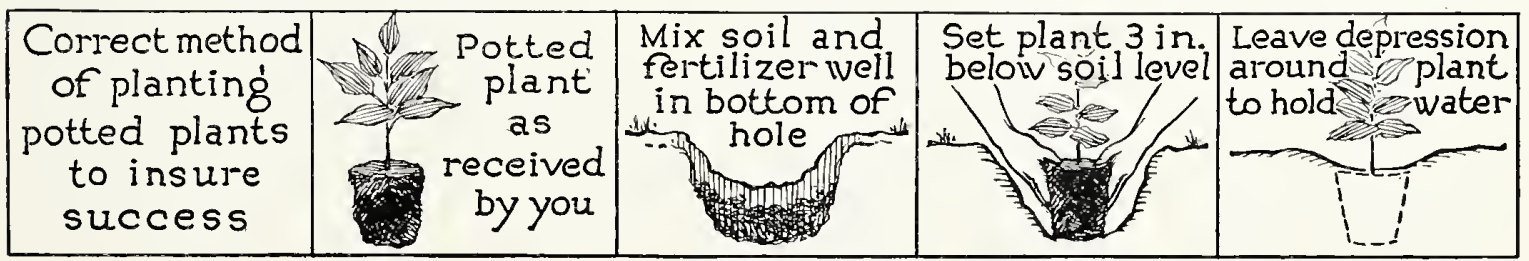



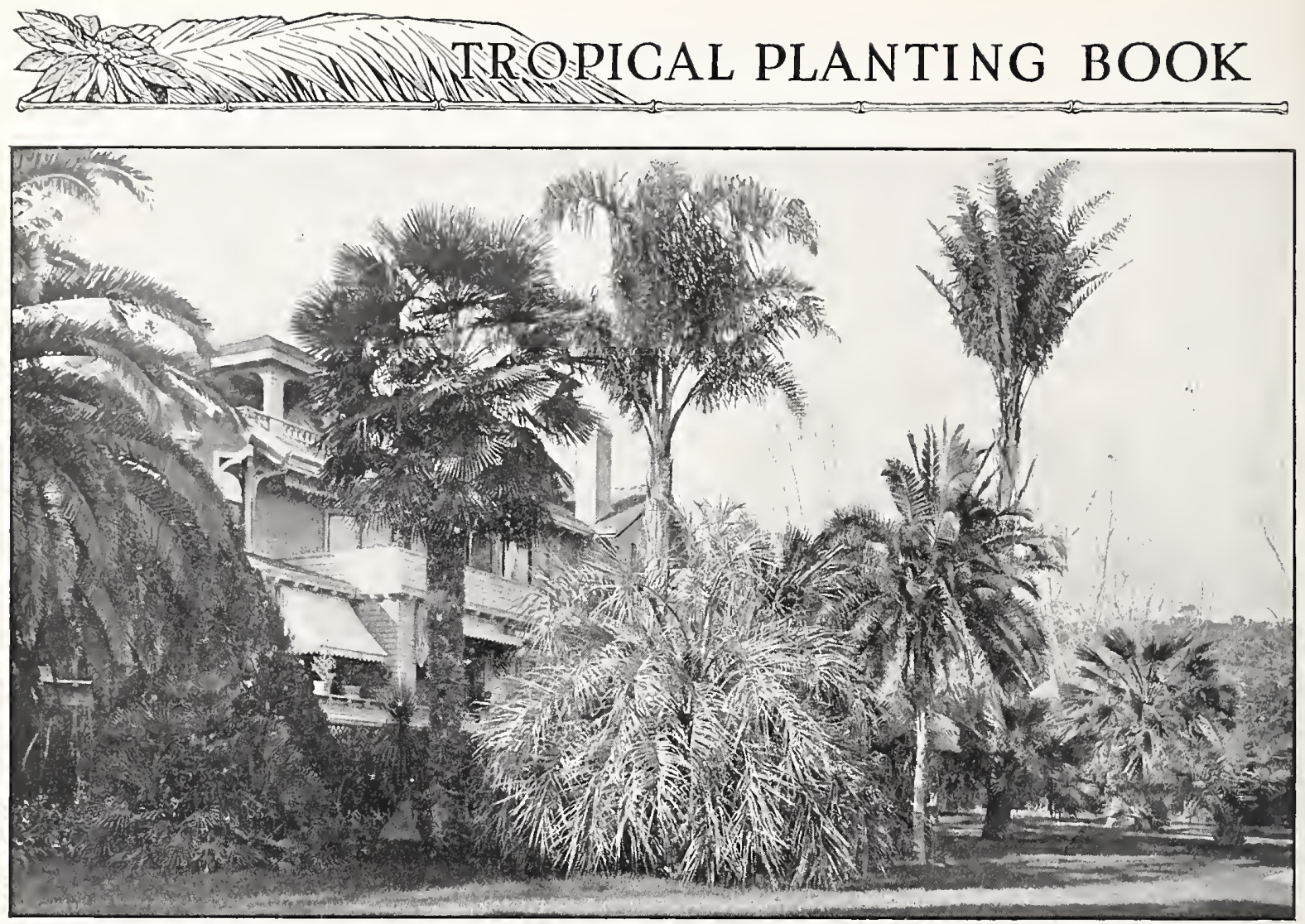

A massed group-planting of Palms

\section{Palms and Cycads}

I $\mathrm{N}$ ALL the wide realm of the Tropics, where Nature is most lavish in the display of her charms, no subject equals the PaIm in lending character and distinction to the scene. And nowhere in this country is it possible to cultivate successfully so extensive a group of varieties as here in Florida. While the hardier types can be grown throughout the southern section of the country, especially along the Gulf Coast and in the great Southwest, it is in Florida that the Palm reaches its perfection. But because of its striking personality it is exceptionally difficult to avoid mistakes in handling it in landscape work-a misplaced shrub or even tree will often be overlooked, but badly misplaced Palms stand out so strikingly that the error is doubly unpardonable. The commonest of these faults is seeking the open plaees in which to plant them-nine out of ten people will break up the so valuable foreground with a meaningless scattering of Palms, whereas a study of tropical landscape repeatedly demonstrates that the most attractive pictures are secured where Palms rise in stately fashion out of masses of verdant foliage, or perhaps even stand out a little from such a background, yet more or less closely identified with it. Even when planted in large massed groups, they are most striking when the "up-ended feather duster" effect is relieved by contrasting foliage as ground-cover or broken groups of shrubbery.

Another too frequent error is planting a Palm or two in the middle of lawn spaces in front of the house on town lots - this not only serves to shorten an already too limited foreground, but when the Palnis develop they will break up the view of the house into a series of panels instead of framing in the picture of the house as they should. On larger properties where there is more foreground and where there is a striking central entrance or core to the building, two stately Palms ean be used to advantage, set near the entrance and framing it in, if the remainder of the planting supports this scheme. But in the first instance mentioned, such procedure is ruinous-rather plant them at the corner of the building or toward the rear where they may not be so

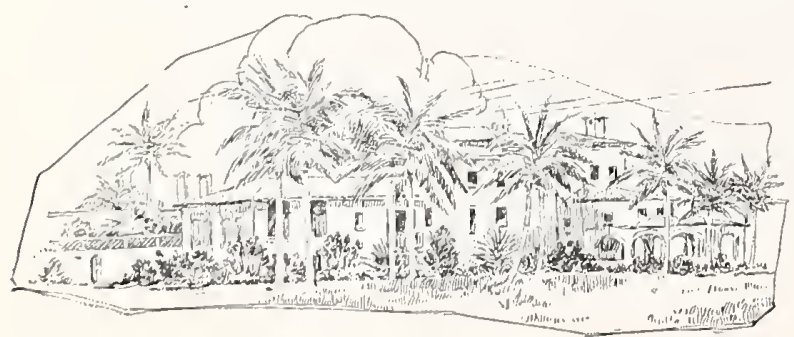
conspicuous in early years but later will lend real charm and character to a usually flat and uninteresting sky-line. When planted in groups only, the same or similar kinds should be used together. Otherwise the effect will be confusing and lacking in dignity and singleness of purpose, as necessary in the landscape picture as with the painter's canvas.

Never Plant Curving Drives to Formal Rows of Palmis. Such situations should be planted to grouped 


\section{ROYAL PALM NURSERIES}

Palms or trees and massed shrubs - formal plantings of Palms in rows are most effective in short, straight vistas.

Special Notice. Our Paims are all pot- or tub-grown, exccpt where noted otherwise, and may be shipped at any time of the year. For Florida planting the warmer months of the year are best-either in spring, if water is no consideration, or during the summer rainy season.

The Palm Is One of Our Specialties and we grow many thousands of plants annually. As we use no heat, except for a few days in winter, they are healthy and stocky and in condition to ship at any time of the year. Make the ground very rich, and when once established they can not be fertilized too heavily. Where dry, watering and mulching should be attended to carefully until plants arc established. In the faIl, suspend cultivation and fertilizing to give them opportunity to harden up for the winter. During spring and summer the fertilizer can be heavily nitrogenous, but an application rich in potash can be applied to advantage in early fall to help them harden up well. In pots, soil should be rich and drainage perfect. See potting suggestions on page 5; these are important.

Palms in the house need some sunshine, and will do best with the morning and afternoon sunlight every day, only avoiding the heat of noon. They will exist and live for years with but little light, but are not healthy, nor will they grow fast. An even, rather high temperature suits them best, without drafts of air. The hardier sorts will be able to stand a temperature of 60 degrees Fahr. and do very weIl, but below this they will not make much growth. Even an occasional drop to 45 degrees Fahr. will not kill them, but they would prefer 70 degrees Fahr. most of the time. In summer, Palms will appreciate plunging in the ground to the tops of the pots, in a half-shady, moist situation. Sponge the leaves occasionally to keep them clean and free from insects.

Explanation of Symbols. - * Those hardy enough to grow outdoors along the Gulf Coast or southern California, etc., or in a temperature not lower than 15 degrees Fahr. ** Those less hardy, being able to stand ordinarily a temperature of 26 degrees Fahr. *** Tropical species not being able to stand anything beyond a faint frost. D. Especially recommended for cultivation in greenhouses or for house decoration, although all sorts named may be thus grown if given suitable tempcrature.

All measurements are taken in natural position, above the pots

\section{Group I. For Street Planting and Parkways, Instead of Shade Trees}

The only use of PaIms on streets is for their decorative value-as shade trees they will not answer. Because of a popular desire to get tropical effects in our towns, streets are frequently planted to Palms instead of shade trees and, while this is open to serious objection, when it is done it is most essential that it should be done properly. Never plant more than one species in a row to a street-anything else shows absence of vision and artistic conception of the value of Palms for this purpose. Town councils or other civic organizations would do well to consult with authorities before making indiscriminate plantings and following the advice of "every Tom, Dick, and Harry." We always welcome inquiry by letter, but would much prefer a personal interview or, better yet, a personal inspection of the problem under consideration. Too much thought and study cannot be given this matter.

Following are subjects we especially recommend: COCOS PLumosa. Plumy Coconut. ** D. Brazil. a rival for street work as well as for lawns. Unfortunately, this area in Florida is very limited so that it is necessary to use the nearest substitute for the Royal over most of peninsular Florida. This is the Plumy Coconut so widely used in California as well as in this state. The trunk, erect and columnlike, reaches a height of 40 feet or more and is crowned by a plumy crest of long, feathery, swaying dark green leaves, making a formal and very striking picture. While a quickgrowing subject under good culture, we do not advise planting it where it is going to be neglected the first few years of its growth, as has so often been the case. Some Palms will stand a surprising amount of neglect when small, but the Plumy Coconut is not of that class. Each $10 \quad 100$

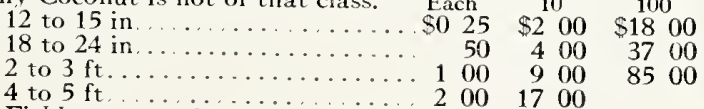

4 to $5 \mathrm{ft}$

$200 \quad 1700$

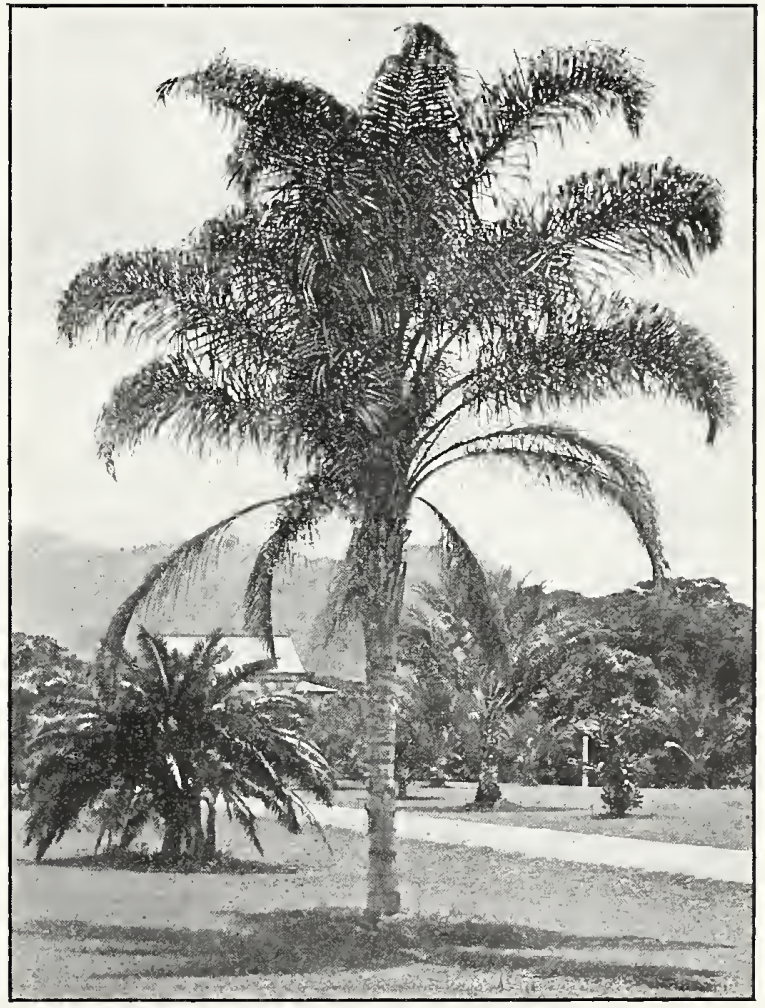

Cocos plumosa. Plumy Coconut 

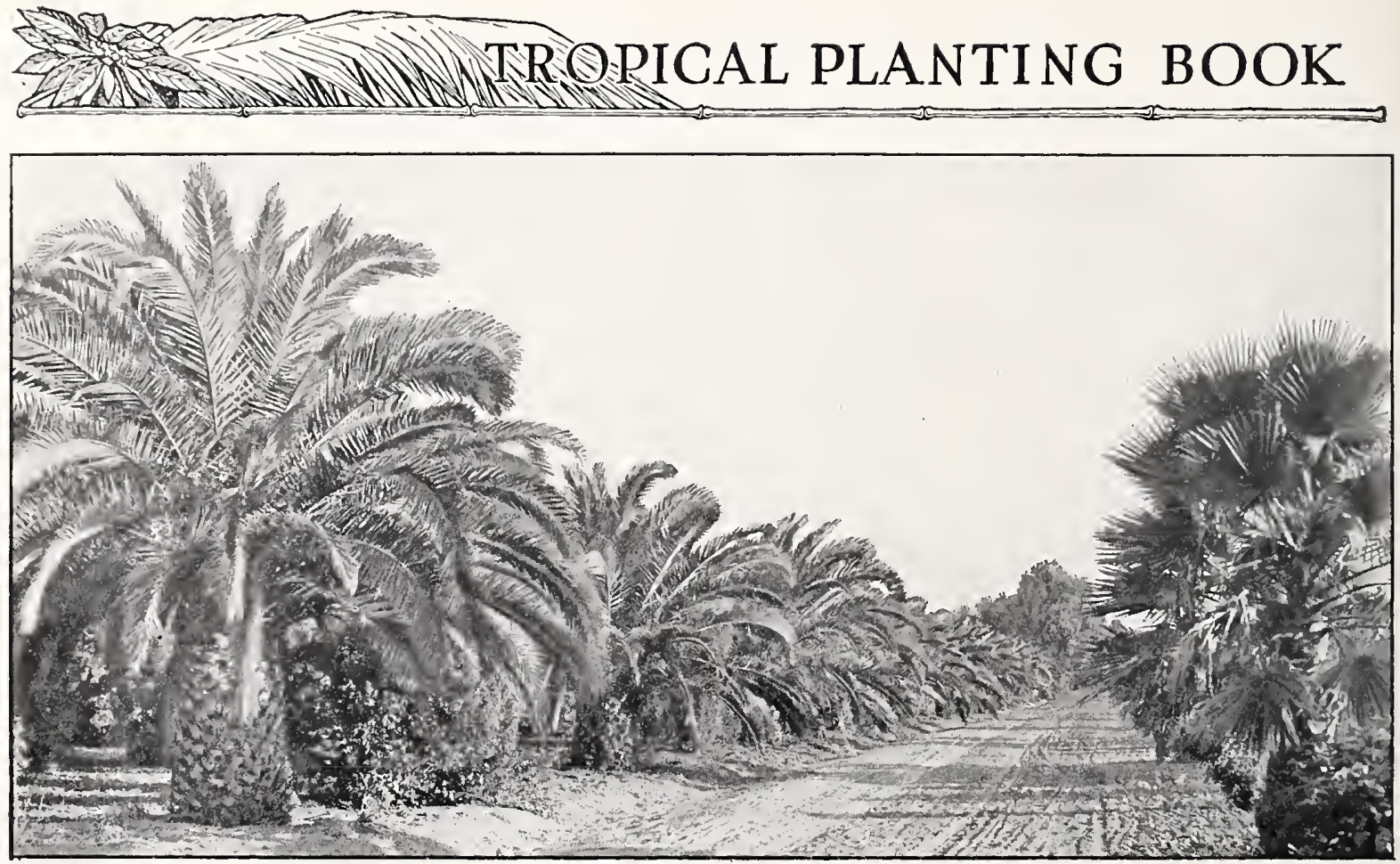

Avenue planted to Phœnix canariensis

PALMS FOR STREET PLANTING AND PARKWAYS, continued

OREODOXA $\begin{aligned} & \text { REgIA. Royal Palm. *** Cuba. } \\ & \text { Without exception this is the most }\end{aligned}$ regal $\mathrm{Palm}$ of the tropical garden and wherever hardy in the state should receive special attention, both for street and park and private grounds planting. Of excecdingly rapid growth, it reaches a height of $125 \mathrm{feet}$, with a straight, columnar trunk, gray in color and swollen at the base. The foliage crown consists of giant leaves 10 to 15 feet long, dark, glossy green. Young plants, $35 \mathrm{cts}$. each, $\$ 3$ for 10.

PHOENIX CANARIENSIS. Canary Island Date. * this splendid genus, with an erect, massive single stem and dense crown of large, heavy, elegant, slightly curving leaves of pleasing green color often 15 feet or more in length. It is a good grower on rich, heavy soils but relatively slow on poor, high sandy soils. This is one of the most conspicuous features of the Florida landscape, making splendid lawn specimens, especially where hardiness is a valuable feature, as in middle and north Florida and the upper GuIf Coast where the more tropical sorts are too tender. Because of its Iarge, dense crown and massive build it is one of the most valuable of Palms for strcet work where parking spaces are sufficiently wide to justify its use. Pot-grown plants, 35 cts. each, $\$ 3$ for 10 ; freld-grown and balled, about 2 ft., $\$ 2.50$ each; boxed specimens, very heavy, $\$ 5$ and $\$ 8$ each.

P. SYLVESTRIS. Wild Date or Sugar Palm.* India. This is one of the most valuable species of the genus, cspecially for lawn decoration. While not so massive as the preceding, it is of much faster growth, even on poorer soils and a developed specimen is of considerably more attractive appearance. Tall-growing, reaching 50 feet or more in height, it has a straight substantial trunk 12 to 14 inches in diameter, which remains clothed with the persistent petiole-bases ("boots") of the leaves. In this network grow many ferns which, with the advent of the summer rains, burst into a fascinatingly interesting drapery of green fronds well up into the crown of the palm. This last is large and compact and of perfect, well-rounded symmetry, consisting of smontl, grayish green leaves 10 to 15 feet long. The fruit, which hangs in immense clusters, is a conspicuous orange-yellow color, and sometimes ripens fairly well into edible dates. 50 cts. each, $\$ 4.50$ for 10 ; freld-grown, balled, about $2 \mathrm{ft}$., $\$ 2.50$ each; heavier, \$4 each.

P. TENUIS. * D. A hardy species somewhat like $P$. canariensis, but with glaucous foliage. $\$ 1$ and $\$ 2$.

SABAL BLACKBURNiaNa. Giant Palmetto. * West Indies. This is undoubtedly one of the most valuable acquisitions to the PaIm group in Florida because of its striking superiority over the native species. Both in trunk and leaves it is far more massive, the latter being simply huge. The trunk reaches a foot or more in diameter and a height of 35 feet or more and is of exceedingly rapid development for a Palmetto. We recommend it most highly. Young plants, 35 cts. and 50 cts.

S. HAVANENSIS. Cuban Palmetto. * This species differs from our native southern Palmetto chiefly in its leaves which are somewhat larger. Young plants, $35 \mathrm{cts}$. each, $\$ 3$ for 10 .

S. PALMETTO. Cabbage Palmetto. * Southeastern U. S. A. A very hardy species with erect trunk 20 to 40 feet high, with large head of fan leaves. Very suitable for street planting on Gulf and Atlantic coasts generally where more tender Palms cannot be used. Plants showing character, 35 cts. each, $\$ 3$ for 10 ; larger, 50 cts. and $\$ 1$ each; field-grown, 2 to $3 \mathrm{ft} ., \$ 1.50$ each.

WASHINGTONIA ROBUSTA. California Fan zona. A fast-growing Fan Palm especially adapted to planting in Florida and the GuIf Coast region generally, and which should be represented in every Florida garden. More picturesque than the Palmettos, both in form and character of foliage, it makes a massive trunk crowned by a compact head of tough "fans" which are copiously furnished with white threads, which have given it another common name of "Thread Palm." Strong plants with character, \$1 and \$2 each; field-grown, balled, 2 to $3 \mathrm{ft}$., $\$ 2.50$ each; 3 to $4 \mathrm{ft}$., $\$ 4$ each. Larger specimens priced on application.

\section{Group II. Palms Adapted to Center Parking Strips in Streets}

This elass is partieularly suited to locations where spceial eonsiderations require plants of smaller erown or more dwarf habit. These should be used only at eonsiderable intervals and for their picturesque and ornamental value only. For this we recommend the following: 


\section{ROYAL PALM NURSERIES

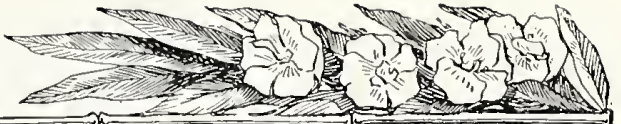

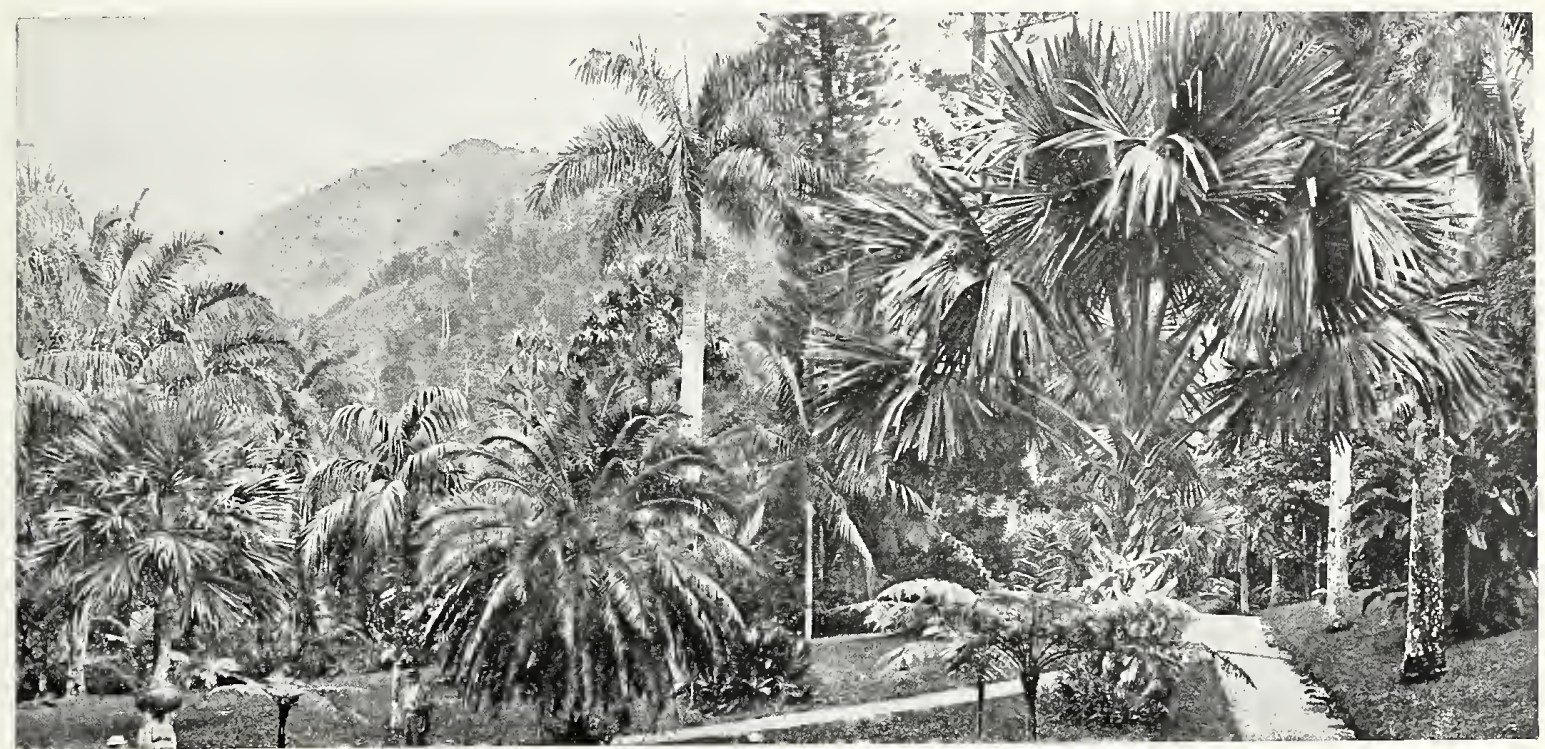

Poorly selected yet impressive planting of mixed Palms

COCOS ALPHONSEI. * This belongs to the so-called australis or hardy type of the genus and is invaluable in a variety of situations. All of this type are distinctly different from others of the genus and a re characterized by being dwarf and bushy in habit, with gray-green foliage, compact and arching, and hardy over all the state, They are also adapted to a very wide range of soils and conditions, thriving well on the poorest sandy soils if given half a chance to get established, as well as on fills made from freshpumped sand along the coast. For decorative work in parkways, they are unexcelled, and we recommend their use generally to all civic organizations interested in the beautifying of their towns. Strong plants, 75 cts. and \$1.50; extraheavy, field-grown, balled, $\$ 3$.

C. AUSTRalis. Pindo Palm. * Paraguay. Nothing appeals to the tourist more than well-planted streets, and while the Cocos of this type are not adapted to street-tree use, they are invaluable on those wider boulevards "which permit the introduction of the central parking strip. This species attains 30 feet in height, and is hardy, with foliage more slender than some of the group. Young plants, $50 \mathrm{cts}$.

C. DATIL. * These more dwarf Cocos of the hardy type are especially well adapted to ornamental use, not only in parkways, but on the smaller lawns where large specimen PaIms are often too big. On larger grounds they are often grouped close together, more like shrubs, and when interplanted with cycas, comptie, and other ground-cover plants of that class, they are most effective. The fruit of this species, like most of the type, is edible - that is, the outer fruity pulp surrounding the inner nut-and is characterized by a pasty consistency. Strong, field-grown plants, balled, $\$ 3, \$ 5$, and $\$ 8$.

C. ERIOSPATHA. * This is one of the Iarger-growing Palms of the australis type, and makes very beautiful specimens for decorative work. Being so hardy, all this group are especially valuable for their pinnate, or feathcr-like character of leaf-so many of the hardier Palms are of the fan-leaved type. Pot-grown, $50 \mathrm{cts}$., field-grown, $\$ 3$.

HYOPHORBE AMARICAULIS. *** This and aiike, but, unfortunately, have been so frequently planted without discriminating taste that, as a rule, they do not appear to advantage, though in reality they are strikingly beautiful subjects. In some instances they have been used to interplant between Washingtonias and other tall-growing fan Palms lining street or walk and in this position they appear to great disadvantage. We urge that they be used wherever they are hardy, but grouped to better advantage. We can furnish strong plants at $\$ 2$ each.

H. VERSCHAFFELTII. *** D. Mauritius, This makes a stout Palm with trunk 25 to 30 feet high, and 6 to 8 inches in diameter, though of relatively slow development. The pinnate leaves are 4 to 6 feet long and tinted orange-yellow, making it a very distinct horticultural subject of beauty and interest. $\$ 1$ and $\$ 5$.

LATANIA borbonica. Chinese Fan Palm. See Livistona chinensis.

LIVISTONA CHINENSIS (Latania borbonica). Chinese Fan Palm. * D. China. A hardy, rather slow-growing species with a stout trunk and many leaves, 4 to 6 feet in diameter. This is a highly ornamental subject, formerly more widely used as a house Palm than any other kind. Makes a fine decorative plant for either indoors or open air in the extreme South. Strong plants, \$1, $\$ 2, \$ 4$, and $\$ 6$.

L. HOOGENDORPII. *** Java. A tall Palm with rich dark green leaves much plaited and deeply divided, forming a complete circle. Petioles stout and armed with sharp spines at the edges. \$1.

PHOENIX ROEBELENII. *** D. A very dwarf in plants at $\$ 1$.

RHAPIDOPHYLLUM Palmetto. $_{\text {Pyst }}^{\text {Porcupine }}$ D. Central Florida. This is a comparatively slow-growing dwarf Fan Palm with very distinctive and characteristic long dark brown spines from the bases of the petioles, whence its common name. Of beautiful effect, especially in the colder sections of the state where, because the variety of suitable Palms is limited by cold, it should be more generally grown. $\$ 1.50$ and $\$ 3$. THRINAX MICROCARPA. Silver Thatch Palm.

NAX* D. Happy, indeed, and fortunate, are those who can grow one or more of these lovely Palms in their gardens. A dwarf PaIm of perfect grace and symmetry with lovely fan-shaped leaves, silvery on the lower side, it is a dream of sheer beauty and can be introduced into the shrubbery borders of enclosed gardens or around mirror-pools with telling effect. Like all of this genus, it makes a most effective pot-subject for conservatory or living-room. Nice young plants with character, 50 cts.

T. SPECIES UNKNOWN, *** D. One of the newer dwarf Fan Palms with dark green, exceptionally deeply cleft leaves. This is especially valuable for table decoration, window-boxes, etc. Beautiful plants, $50 \mathrm{cts}$. and $\$ 1$.

T. WENDLANDIANA. Thatch Palm. *** D. A Florida and West Indies PaIm of rare beauty, with deeply cleft, fanshaped leaves, and reaching a height of some 10 or 12 feet. This should be in every tropical garden in south peninsular Florida. $\$ 1.50$ and $\$ 3$. 

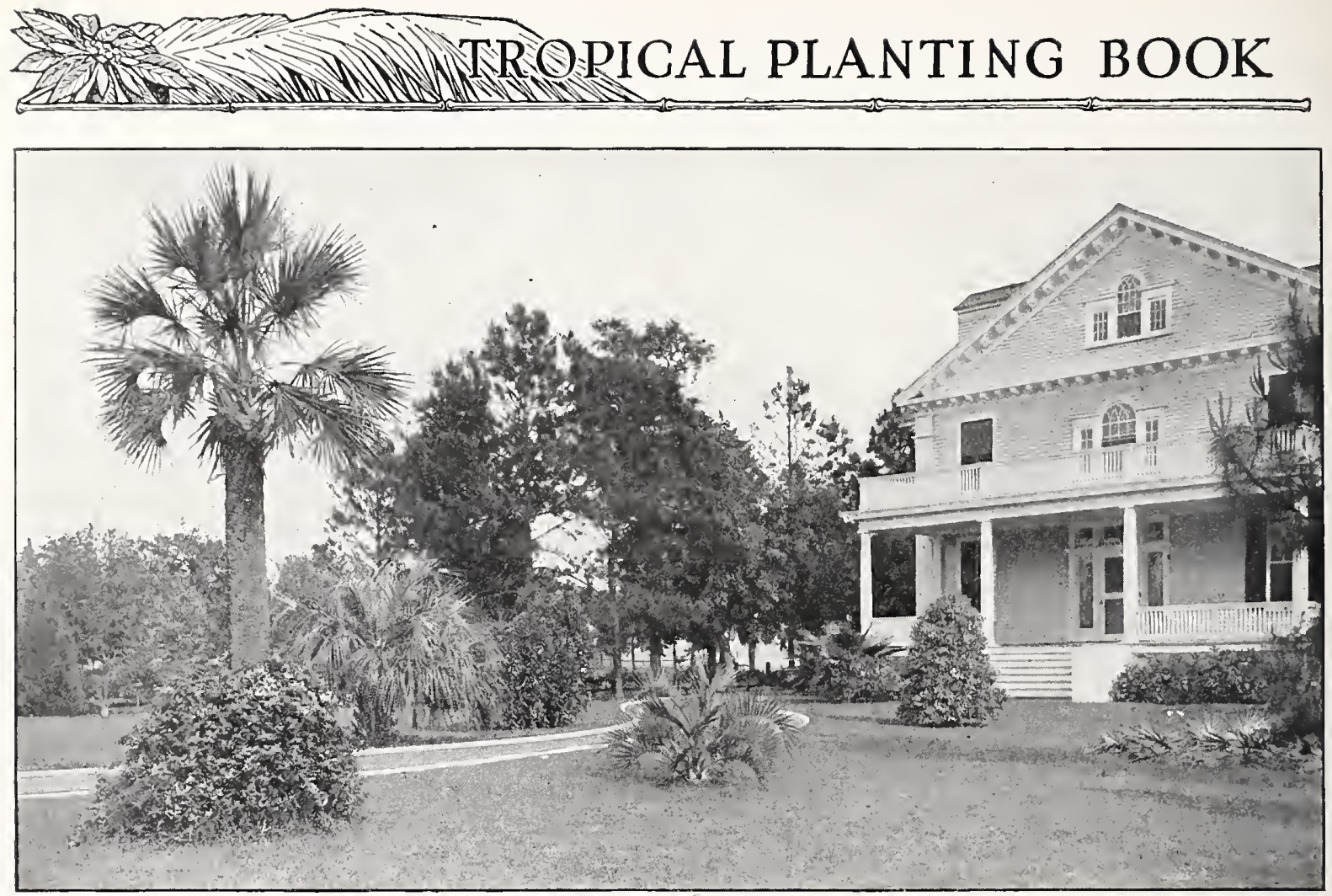

Palms as lawn specimens

\section{Group III. Palms for General Lawn Planting, Parks, Etc.}

Remember, when you locate each plant that it is to serve a purpose and that it should have some signifieance in your plan of the garden, bearing a distinet relation to the planting and your home. Don't make an exotie pet of it! We reeommend all the foregoing, and also the following:

ACROCOMIA TOTAI. ** South America. Were we would classify it not for the thorns of this Palm, we would classify it with the street trees, for it is a subject of exceptional beauty, with its erect, columnar trunk of 10 to 15 inches, reaching 40 to 60 feet in height and crowned by a magnificent tuft of graceful, feathery leaves. Both trunk and petroles of leaves are covered by long, stout spines which render it fit only for lawn planting away from possible contact by the general public. Planted in masses of shrubbery, it loses its objectionable feature, bcing out of the way, vet its splendid form and texture make it valuable indeed in landscape work. \$1 each, $\$ 9$ for 10 .

ARENGA SACCHARIFERA. Sugar Palm. *** Java. Malaya. Without question this is one of the very handsomest of tropical Palms and, while restricted to extreme South Florida in this country, it should there receive more attention than it does. Without any disposition to minimize the beauty or value of the Royal Palm, therc are frequently situations where this subject could be used to just as good, if not better, advantage in securing landscape effects in extensive gardens, especially in the shrubbery border, where its cnormous, shining, dark green pinnate leaves, arching gracefully overhead, makc a never-to-beforgotten picture. In Java it has an economic value, being used for the production of sugar from its sap. $\$ 2$.

CARYOTA URENS. Fishtail or There are handsome specimens of this Palm at numbers of points in the state, and with a name such as it has, it should become a common sight wherever it is hardy. Its first cognomen is derived from its bipinnate leaves which bear an odd but very striking resemblance to the tail-fins of a fish. With a trunk of 10 to 15 inches in thickness, it is of rapid growth and makes an exceedingly ornamental subject, either out of doors or for potculture indoors. $50 \mathrm{cts}$.

\section{CHRYSALIDOCARPUS LUTESCENS. (Ar-}

D. Madagascar. One of the most favored Palms for potculture, both because of its great beauty and easy growth. It makes a bushy specimen, suckering freely even when very young and develops golden ycllow stems and elegant arched pinnate leaves. Because of its very bushy habit, it is rather better adapted to lawn planting or in massed groups. $50 \mathrm{cts}$., $\$ 1$ and $\$ 1.50$.

COCOS NUCIFERA. Commercial Coconut. *** This cause of the picturesque habit of leaning growth of the trunk, its much swollen base, and arched crown of heavy pinnate leaves. While often used in street work, it is most emphatically not adapted to this purpose and its use should be discouraged. For waterfront walks, lawns, specimens, and massed groups in informal treatment it is without an equal, and for those purposes we recommend it highly. Strong potgrown plants, $\$ 1$ and $\$ 2$.

CYCAS REvoluta. Sago Palm. * D. A magnificent CYAS dwarf subject closely resembling a Palm for which it is often mistaken. It has a dense symmetrical crown of handsome dark green leaves. Quite hardy over Florida and the Gulf Coast, it succeeds with slight attention and on a great variety of soils. It is especially valuable in landscapc work as a "touch plant" in getting that eflect of architectural symmetry and finish so much desired in patios, formal gardens, and like situations, for which purpose it is unexcelled. In house culture, be sure to give it a light, sunny exposure, especially during spring and early summer while it is making its most rapid growth. Beautiful plants $50 \mathrm{cts}$., $\$ 2$ to $\$ 6$. 


\section{ROYAL PALM NURSERIES}

DICTYOSPERMA RuBRA, *** D. Tropica I quisite grace and elegance, has frequently been planted near large buildings, in great open places, etc., where it is dwarfed into relative insignificance. It should rather be used in low shrubbery borders or in the formal garden or patio with other smaller growing subjects where it will appear to better advantage. In its young state, the pinnate leaves are prominently marked with red, but as it matures it more closely resembles the Seaforthia than any other subject outside its genus. $\$ 1$ to $\$ 5$.

D. SPECIES. *** This slender-trunked Palm with dark green leaves closely resembles the foregoing and is adapted to the same uses. $35 \mathrm{cts}$, to $\$ 1.50$.

ELAEIS GUINEENSIS. Oil Palm. *** D. West Africa. An ornamental PaIm, with stout stems yield a valuable oil used in the manufacture of soap and candles. $\$ 2$.

LATANIA COM MERSoNII.*** D. Mauritius. there are several fine specimens in the extreme southern part of the state. The leaf-stems are large and smooth, and the gray-green leaves have the ribs of the segments colored bright crimson. The trunk is rather slender and makes a tree 10 feet or more high. Strong plants, \$3.50.

LICUALA SPIN OsA. *** Java. A desirable ICUALA greenhouse and exhibition Palm, having slender trunk with leaves 3 feet or more across. $50 \mathrm{cts}$.

PAUROTIS WRIGHTII. ** This native of extreme AUROIS southern Florida resembles Chrysalidocarpus in its suckering habit and should be used in much the same way. Its fan-shaped leaves are silvery on the under surfaces and the suckers reach a height of 30 feet. Very small plants only at $25 \mathrm{cts}$. each, $\$ 2$ for 10 .

PHOENIX OUSElEyana ( $P$. bumilis). ** D. North HOENIX India. A dwarf Palm with short, tufted stems, and leaves somewhat glaucous green. $\$ 1$.

P. PUMILA. ** D. A quick-growing Palm, attaining 20 feet or more, with slender trunk 6 inches in diameter. Leaves drooping, 10 to 15 feet long, and of a glossy dark green color. 35 cts., $50 \mathrm{cts}$, and $\$ 1$; field-grown, balled, $\$ 3.50$ to $\$ 8$

P. RECLINATA. ** D. Africa. Too much cannot be said in praise of this very lovely subject, valuable for either out-of-doors landscape work or for pot-culture. Normally this plant makes a great bushy clump of many suckers from the main stem, but it can be trained to a single slender stem by removing the suckers each year for several years, when they will finally cease to sprout out. However, we do not recommend this, as the tall, slender trunk, of more or less uncertain steadiness of appearance, oftentimes really crooked, is a pitiable sight - far better to let it take its natural course and develop along the lines for which it is best suited and really most at tractive. The leaves are dark green, arching, recurved and very numerous, making one of the most attractive species of the group. For landscape work it should have plenty of room if intended to develop as an individual specimen-too frequently it is crowded into a small patch of Iawn where it is soon out of all proportion. Nice plants from 4 -inch pots, $35 \mathrm{cts}$. each, $\$ 3$ for 10 ; larger, with character, 50 cts., $\$ 1$ and $\$ 2$. Field-grown, 2 to $3 \mathrm{ft}$., \$2.50. Large specimens priced on application.

P. SENEGALENSIS. ** D. A variety resembling $P$. reclinata, only of coarser texture. Strong plants, $\$ 2$ and $\$ 3$.

PTYCHOSPERMA ELEGANS. Seaforthia.

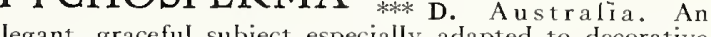
especially adapted to decorative purposes, which in garden culture attains a height of 60 feet. In landscape work, it should receive the same attention as Dictvosperma rubra, which see. The smooth, slender trunk is crowned by numerous dark green pinnate leaves up to 10 feet long. This is one of the best Palms for the South generally indoors, where it stands chilly rooms admirably. Each

Plants showing character.................\$0 50

2 to $21 / 2$ feet........................... 150

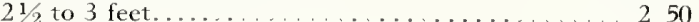

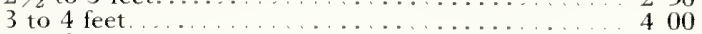

In tubs.

Specimens at higher prices.

P. MACARTHURI. *** D. A dwarf species with slender ringed trunk and suckering freely at the base, making attractive, bushy specimens. Of special value in patio and formal garden work in extreme South. \$1 to \$3.

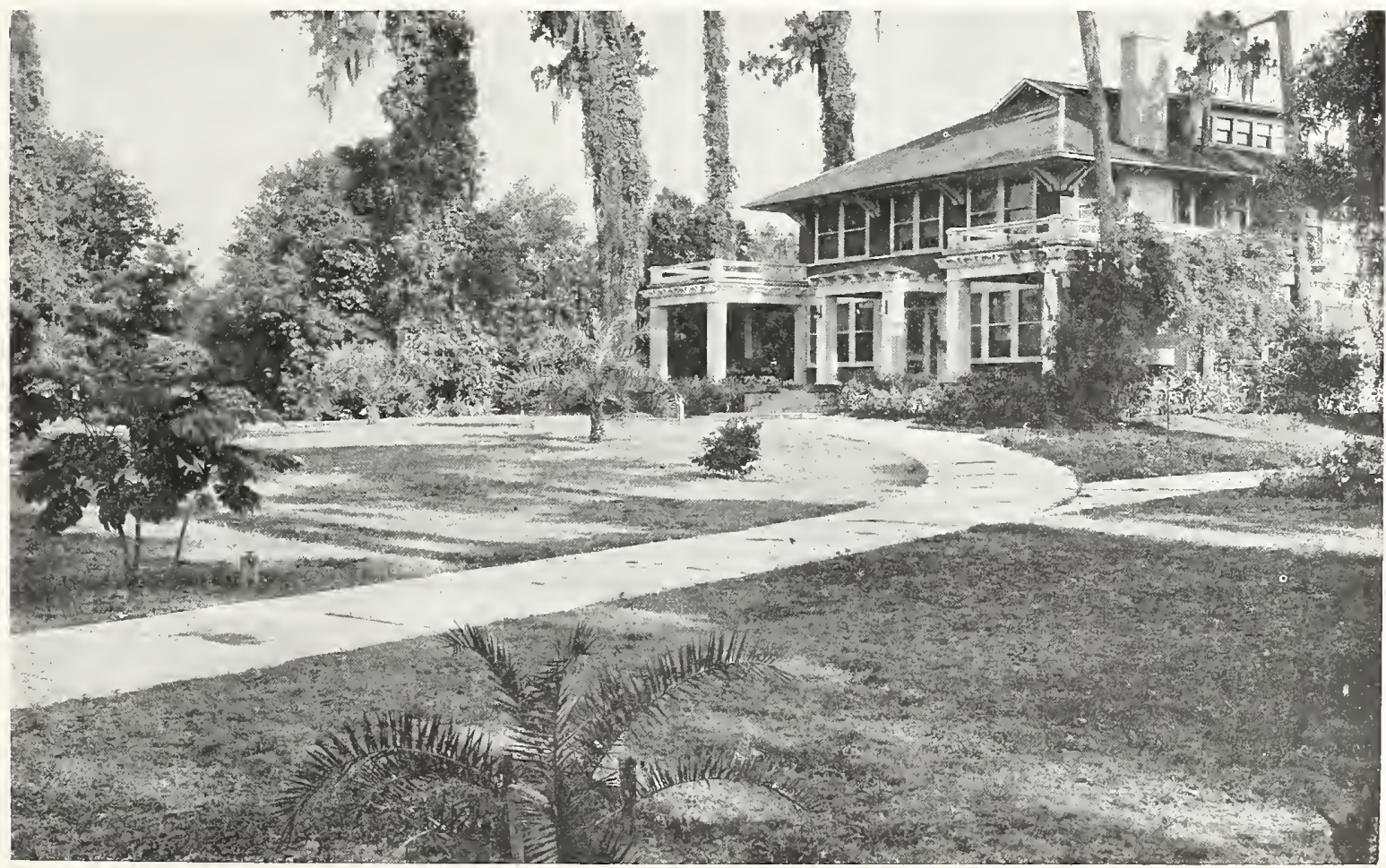

Natural Florida planting enhanced with exotics 

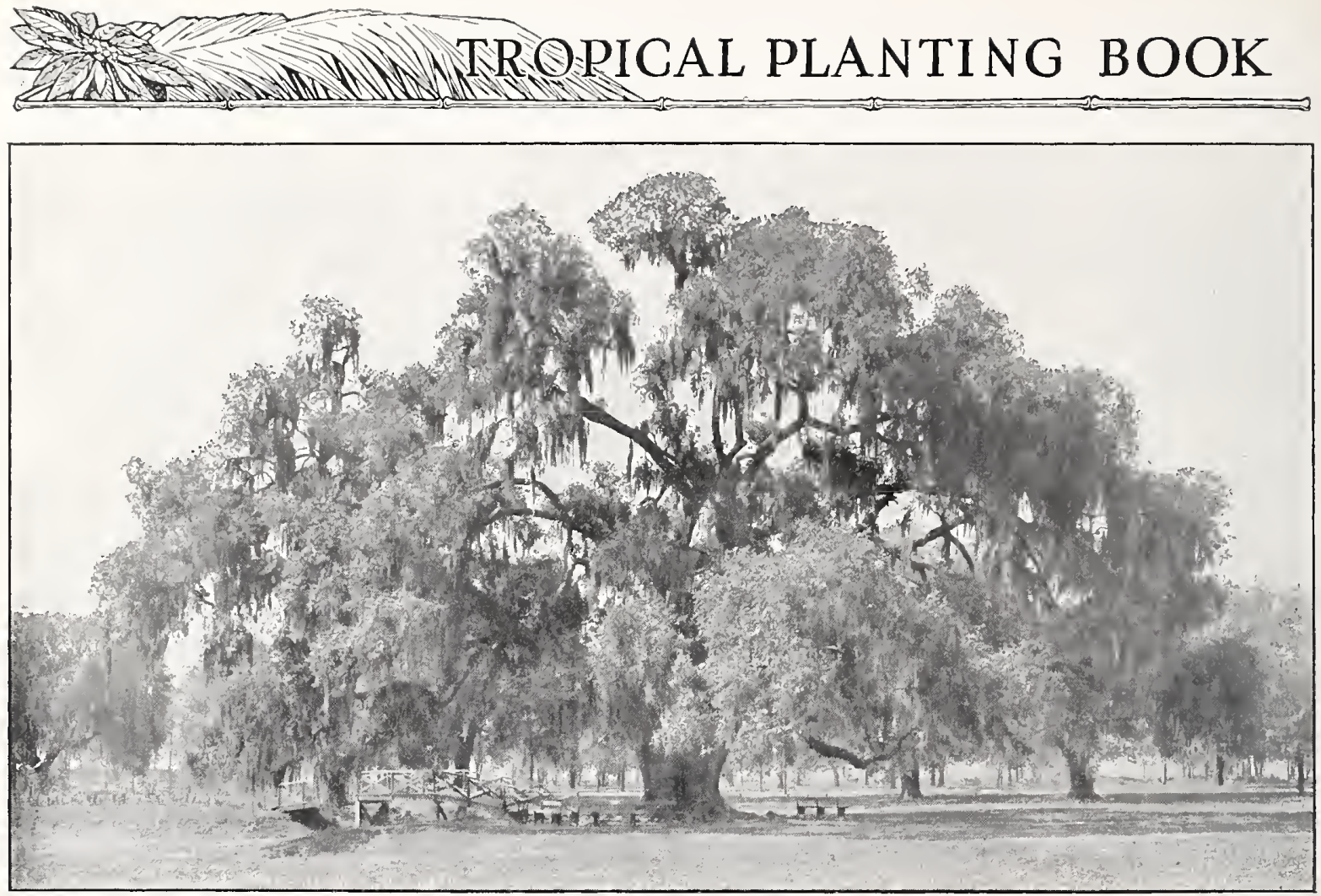

A study in tree framework-Live Oak

\section{Shade Trees}

I T IS strange, and unfortunate, that in spite of all that has been said and written on the subject of reforestation and conservation of our natural resources, not to mention the esthetie side of the situation at all, that the destruction of fine shade trees goes on. Nowhere is this more true than in Florida where trees eonstitute a particularly valuable asset. Many settlers and purehasers of new properties seem to think that the proper eourse is to clear off all the native trees as a starter and then wait many long years for exotic specimens to take their places. Do not cut out any trees unless you are absolutely certain that it is neeessary; when you positively determine what is to come out-do not spare the ax!

Having, of course, worked out your plans - or had them executed for you by competent landscape designersproceed to plant the trees first. On the home grounds, as well as in street and park, the ornamental shade trecs add more to the comfort and beauty of the property than any other one subject. How many flat, bleak, and uninviting places could be made attractive by the introduction of a few choice, selected trees! Fortunately, most of our subtropical and tropical sorts are good growers, and there is no excuse for anyone not having a reasonable amount of shade at all times of the year. Serving also as a background, trees give the home a setting and the grounds as a whole proper perspective. Unsightly views and outbuildings should be screened, and trees for this and many other purposes are invaluable. For seashore planting, try Ficus in variety, Pithecolobium, Ilex, Ligustrum, Casuarina, Coccolobis, Delonix, Melaleuea, Achras, Euealyptus, Juniperus, and Live Oaks.

\section{Group I. Trees for Street Planting}

Nothing adds so much to the attractiveness of town or city as well-planted strects. The leading cities of Europe and many in this eountry spend millions of dollars annually in the planting and maintenance of their street trces. Almost invariably the character of a town and of its citizens is indelibly marked by the interest exhibited in street and park planting. Not only are trees of paramount importance in shaping the character of a city's future citizens and a source of comfort and pleasure to all, but in Florida particularly - a state in large measure dependent on the patronage of a large tourist population - it is a matter of hard business sense to make the town as appealing from every viewpoint as possible. And nowhere can a start be made to better advantage than in the streets and parking places. Cities, plant some trees now!

Special Notice. Our stoek of trees falls into two classes, pot-grown (marked $\mathbf{P}$ ), and from open ground. The former may be transplanted at any time, as their roots are but little disturbed and injured. The latter elass should be sct preferably during the winter months when dormant. 


\section{ROYAL PALM NURSERIES \\ $\longrightarrow x$}

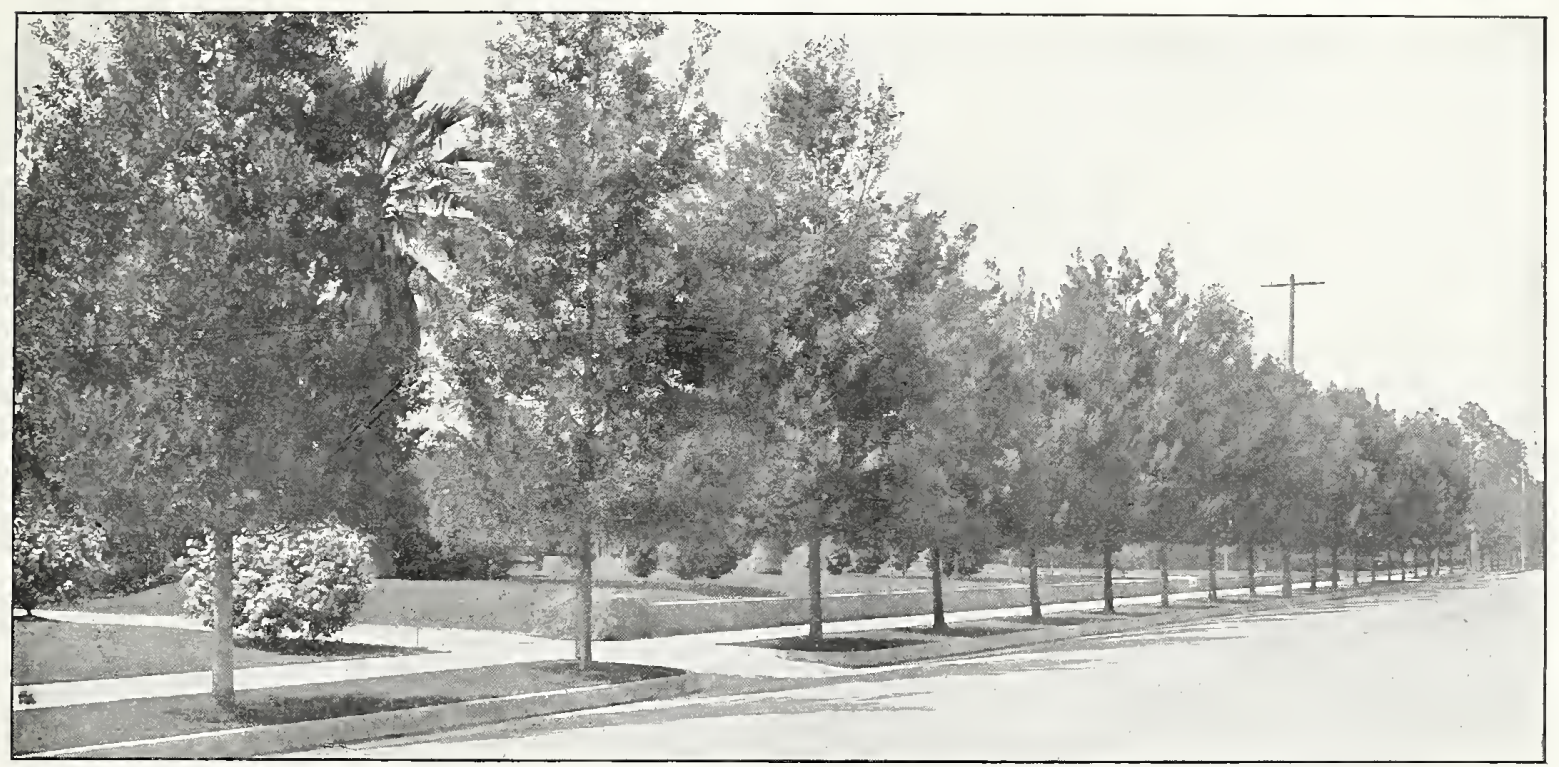

Note how much more attractive is this uniform street planting than that of the average Florida street

Species marked $\mathbf{T}$ are suitable only for extreme South Florida and the Tropics, or for growth in large conservatories. Those marked $\mathbf{H}$ are more hardy and can generally be planted throughout Florida and the Lower South. Those marked ST are an intermediate- that is, while not adapted to Florida planting generally, they can be used through southern Florida, resisting considerable frost, and even when frozen back somewhat, come right out again. This last class should receive some protection during the coldest weather the first two years. When in doubt, be sure to communicate with us. A few are used as decorative pot-plants when small, as Ficus, Grevillea, Jacaranda, and others. In addition to those regularly described we have noted certain tree-like shrubs that may be grown as street or shade trees and also some fruit trees adapted to the same classes of planting.

ACER RUBRUM. Scarlet or Swamp Maple. H. Native. turns brilliant scarlet or orange in autumn. A valuable subject for street and park planting because of its excellent upright habit and the earliness of the scarlet flowers which appear in midwinter in Florida, followed by bright red seeds in early spring. 2 to $3 \mathrm{ft} ., 25 \mathrm{cts}$. each, $\$ 2$ for 10 ; 3 to $5 \mathrm{ft}$., $50 \mathrm{cts}$. each, $\$ 4$ for $10 ; 5$ to $8 \mathrm{ft}$., $75 \mathrm{cts}$. each, $\$ 6.50$ for 10 .

BAUHINIA PURPUREA. Mountain Ebony. T. especially valuable for narrow streets and private residential "places" where large trees are disproportionately out of place. There are occasions where the failure of the town-plan to provide adequate roadway makes it desirable to eliminate the park-space reservation, in which case Bauhinias are well adapted to planting on the property lines. They are very showy subjects, the large bilobed leaves falling in late winter, followed by a profusion of bloom that lasts for weeks. The flowers of this form are 3 inches across, of pleasing shades of lavender, mauve, purple, and white, resembling rare orchids and quite fragrant. By judicious pruning this may be kept within the bounds of a large shrub, either in shrubbery borders or as specimen tub subjects. The fact that it stands somewhat more cold than most tropical subjects, makes it all the more interesting for Florida planting. P. 1-yr.-old, 25 cts. each, $\$ 2$ for 10.

B. ALBA. White Mountain Ebony. T. Practically identical with the preceding except in its pure white bloom. A grand subject with its glorious mass of flowers from January to March. P. 1-yr.-old, 25 cts. each, $\$ 2$ for 10.

\section{CINNAMOMUM CAMPHORA. Camphor Tree.}

tree, hardy throughout Florida, of good size and with widespreading branches, making a handsome, dense top. Thrives on even poor upland soils of the state and is valuable to the Gulf Coast region for the production of camphor gum. For this purpose, set 6 to 8 feet apart, in rows 12 to 15 feet apart.
The twigs are sheared twice a year or more for distillation, usually commencing in the fourth year. This tree is also suitable for larger hedge work, forming a dense, impenetrable fence when properly grown and sheared. For street planting it is very satisfactory, for which use we recommend planting not closer than 40 feet apart. Half that distance could be adopted in order to get immediate effect if the town will resolutely determine to cut out the alternates when they begin to touch-but the trouble is then that most people do not have the heart to do this. So we recommend the greater distance. P. 25 cts. each, $\$ 2$ for 10 ; larger, $50 \mathrm{cts}$. each, $\$ 4$ for 10 ; heavy stock from open ground, $\$ 1$ to $\$ 5$.

FICUS ALtissima. T. India. A very large, tall, leaves of large size and beautifully veined. A splendid subject particularly well adapted to street work in extreme South Florida and the Tropics, because of its upright habit. Because of its root system, however, it should not be planted in narrow parking spaces. As a lawn tree, too, it is most useful and exceedingly beautiful. P. Strong stock, $50 \mathrm{cts}$., $\$ 1$, and $\$ 1.50$ each.

F. BEN JAMINII. T. Australia. One of the handsomest of street trees for lower South Florida and the Tropics because of its symmetry of form and the lovely weeping effect of its smaller branches and small foliage. We esteem it most highly and consider that for use on the East Coast, from Palm Beach south, and on the West Coast, from Fort Myers south, it is a street tree of particular merit that has been neglected by planters. It is highly prized in Australia where it is much used for street and park work as well as on private lawns. P. Strong stock, $\$ 1$ each, $\$ 9$ for 10.

F. BREVIFGLIA. T. Florida. A strong-growing, native evergreen tree, reaching 30 feet in height. The rather small leaves are thin and only slightly leathery, broad at the base and acute at the tip. A symmetrical but rather open-headed tree, bearing bright-red fruits, valuable as a shade tree for South Florida. P. Strong plants, 35 cts. each, $\$ 3$ for 10; extra strong, $50 \mathrm{cts}$. each. 


\section{SHADE TREES FOR STREET PLANTING, continued}

FICUS INFECTORIA. T. Tropical Asia. This is another of the small-leaved "rubbers" that, like Ficus benjaminii, is attractive both in form and leaf and of intcresting wecping habit of growth. For lawn planting we recommend cutting it back to the ground after it is well established in order to make it branch strongly from the base and make a vase-like form of growth. It is a splendid, vigorous sort, reaching 60 feet in height, that should be widely grown wherever hardy. P. Fine plants, 75 cts. each, $\$ 6.50$ for 10.

F. MACROPHYLlA. Moreton Bay Fig Tree. T. Australia. One of the finest of Australian street trees, claimed to be hardier than most of the genus. Leaves are large, resembling F. elastica, only more tapering. The gencral growth is upright. P. Strong plants, \$1.

F. NITIDA. Indian "Laure1." T. This is, without a question, one of the very handsomest of tropical shade trees, being widely famed in the West Indies where it withstands the severest winds - anything short of hurricanes! In form it is tall, roundish pyramidal, upright, and with very dark green foliagc of great beauty. The leaves of this variety are small, thick, and glossy, and are borne in dense profusion. P. Strong plants, $\$ 1$.

GREVILLEA $\begin{aligned} & \text { ROBUSTA. Australian Silk Oak. } \\ & \text { ST. A tall, rapid-growing tree which }\end{aligned}$ normally reaches 120 feet in height, but which, by cutting out the top when it has reached a good size, makes a spreading, fine top. The leaves are pinnate, of feathery, fern-like appearance, making very graceful and attractive young pot plants for decorative purposes. The tree is cvergrecn, very droughtresistant, and altogether well adapted to growing as street or lawn tree in South Florida and California, being as hardy as the orange tree. In the spring the tree is a mass of orangeyellow flowers in large trusses. For street planting we recommend that the trees be placed about 30 feet apart. P. Strong plants from 3 -in. pots, 15 to $20 \mathrm{in}$. high, at $25 \mathrm{cts}$. each, $\$ 2$ for 10 ; from 4 -in. pots, 2 to $2 \frac{1}{2} \mathrm{ft}$. high, $35 \mathrm{cts}$. each, $\$ 3$ for $10 ; 3$ to $31 \frac{1}{2} \mathrm{ft}$. high, $50 \mathrm{cts}$. each, $\$ 4.50$ for 10 ; from open ground, very heavy, $\$ 2$ and $\$ 3$ each.

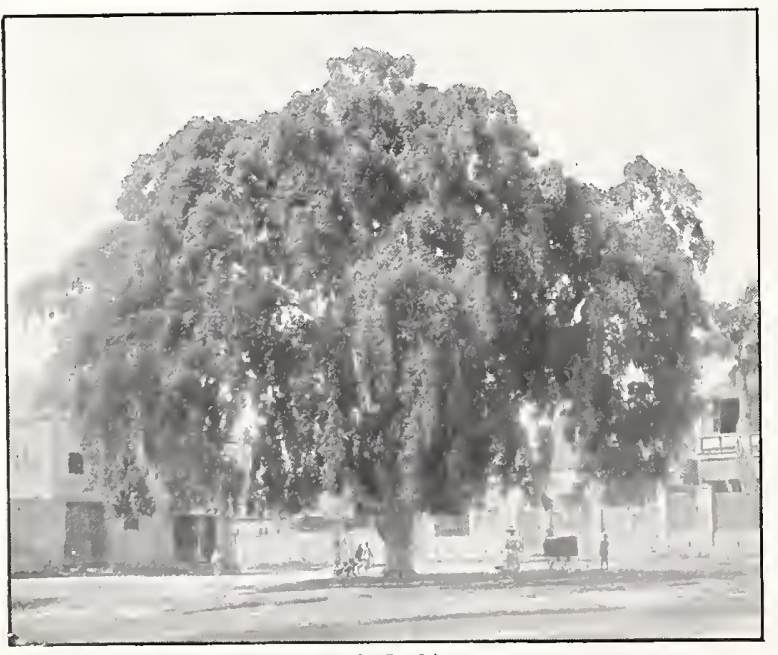

A tropical Rubber tree
LIGUSTRUM JAPONICUM. Japanese Privet. H. tree of upright growth and with thick, dark green foliage strongly suggesting the northern lilac, Of dense, symmetrical growth, we suggest it for the same purposes in street work as the Bauhinias (see page 13). The white, fragrant flowers are of small size but borne in profusion in loose panicles. Finc grafted stock, 5 to $7 \mathrm{ft}$., $\$ 2$ each, $\$ 18$ for 10 : 7 to 9 feet, $\$ 3.50$ each.

MAGNOLIA Grandiflora. Magno1ia. H. AGN Native. A tall, evergreen tree, up to our broad-leaved southcrn evergrcens. The immense leaves are rich, glossy green above and brownish pubescent beneath. The lemon-scented flowers are waxen white and 6 inches across. Fine stock from open ground only, $3 \mathrm{ft}$, $\$ 1$ each, $\$ 9$ for $10 ; 5$ to $7 \mathrm{ft}$., $\$ 2.50$ each; 7 to $9 \mathrm{ft}$., $\$ 3.50$ each.

PITHECOLOBIUM DULCE. T. Mexico. A high, with very attractive rather light tree over 40 feet excellent form and habit of the trec make it one of the most desirable ornamental trees for extreme South Florida planting. Bears twistcd pods containing sweet orange-colored pulp, ediblc and wholesome. P. Nice plants, 35 cts. each, $\$ 3$ for 10; heavier, $50 \mathrm{cts}$. each, $\$ 4$ for 10.

QUERCUS. Oak. H. Of the native evergreen Oaks ularly valuable for street and lawn planting and which we highly recommend. While under ccrtain conditions the moving of these subjects from the woods is desirable, for general planting it will be found that our trained and root-pruned nursery stock will move to better advantagc and make bettcr trecs.

LAUREL OAK. (Sometimes confused with Water Oak.) One of our very handsomest shade trces for general planting in all scctions of the state and of adaptability to almost all conditions. It makes a spreading, round-headed, evergreen tree attaining in cultivation a height of 80 feet or more. Foliage rather small and dark grcen. Of rapid growth and vigorous, it is especially valuable for street planting as well as on lawns, and cannot be recommended too highly. Fine stock, 4 to $6 \mathrm{ft}$., $75 \mathrm{cts}$. cach, $\$ 7$ for $10 ; 6$ to $8 \mathrm{ft}$., $\$ 1.25$ each; 8 to $10 \mathrm{ft}$., $\$ 2$ each.

LIVE OAK. Of slower growth than the Laurel Oak. it is, in reality, especially under cultivation, much more rapid than usually given crcdit for. The evergreen foliage is thicker than that of the Laurel Oak and somewhat rolled under at the edges and more grayish in tone. It makcs a splendid tree for either street or lawn planting and is of much more permanent character, and thereforc more desirablc, than the preceding species. Wc recommend it for more general planting. 4 to $6 \mathrm{ft}$., $75 \mathrm{cts}$. each, $\$ 7$ for $10 ; 6$ to $8 \mathrm{ft}$., $\$ 1.25$ each, $\$ 10$ for $10 ; 8$ to $10 \mathrm{ft}$, $\$ 2$ each, $\$ 18$ for 10 .

STENOCARPUS SINUATUS. Fire Tree. T.

ing to 60 feet or more in height, bearing umbels of bright red, tubular flowers in June. The wood is of value for cabinetwork. P. \$1 each, \$9 for 10 .

STERCULIA ACERIFOLIA. T. Australia. A with very large leaves and rich red flowers in small panicles. P. Nice, strong stock, 75 cts.

S. BIDWILLII. T. Somcwhat like the preceding species, but with rougher Icaves; flowers crimson P. $75 \mathrm{cts}$.

\section{Group II. Trees for Lawn and Park Planting}

The next time you see a fine, sturdy, yellow pine tree, take a few minutes to carefully survey it in detail from where the massive roots strike into the ground in several directions at the crown, up the length of its magnificent netted trunk with its envelope of thick reddish brown bark-seales, to the simple, rugged character of the branching system and masses of elustered needles; do the same with a live oak and all the other trees you meet; you will be surprised at the interest you will develop and the facts you will learn about trees. Then study the shadows they cast on a good smooth lawn, especially when the sun is on the rise or decline-lawn shadows are one of the important considerations in good landscape work. If you haven't thought of that before - do it now! We recommend to your attention all of the varieties listed in Group I and also the following: 


\section{ROYAL PALM NURSERIES}

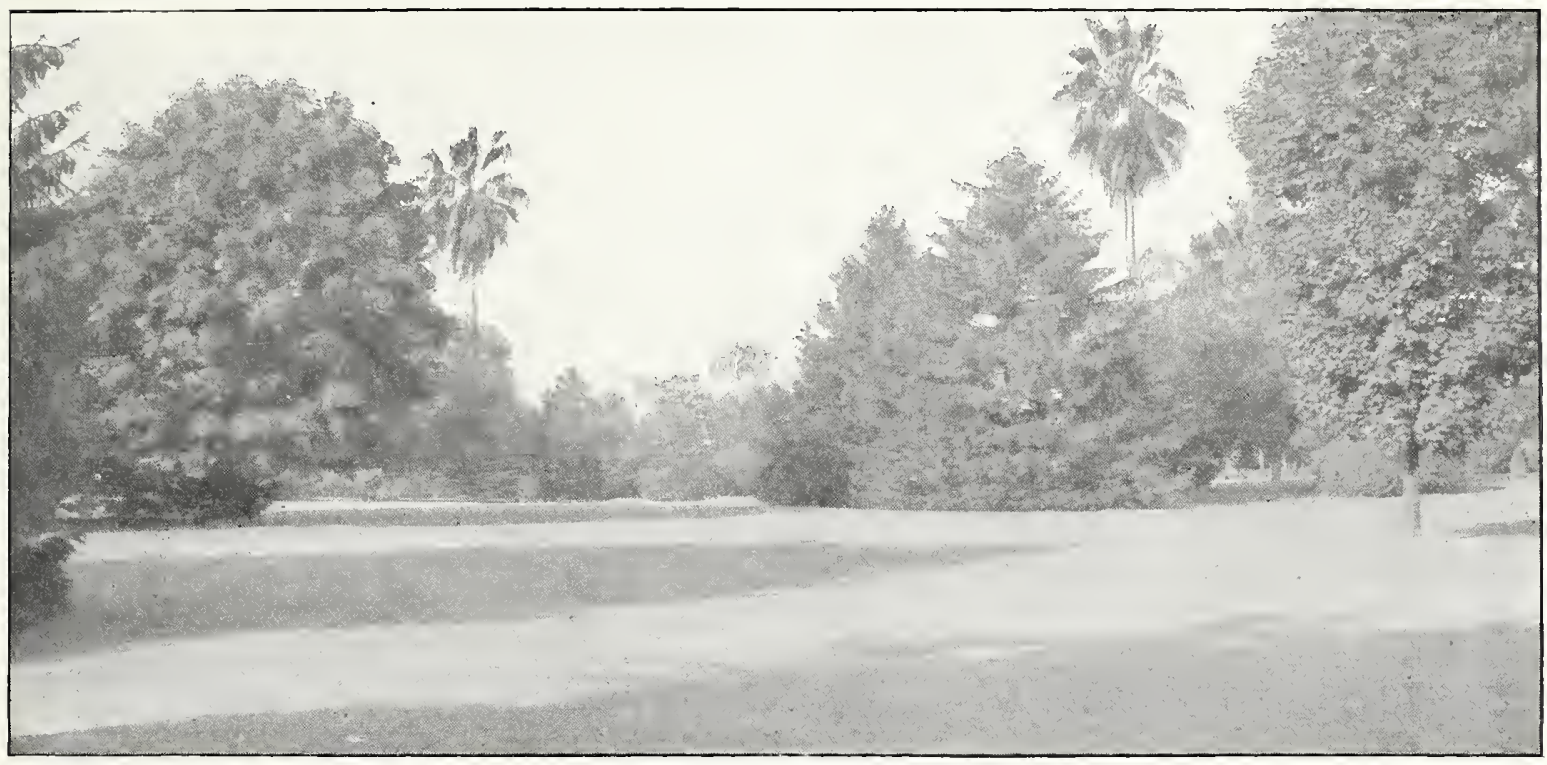

A study in lawn shadows

ACHRAS SApota. T. Tropical America. This ACHRAS most interesting medium-sized evergreen tree, common in this state on the lower coasts and keys, and highly prized for its delicious fruit, makes a lovely lawn subject in extreme South Florida and the Tropics. Symmetrical in habit, with branches arranged in tiers, and broad, glossy green leaves, it reaches a height of 25 to 30 feet. It is especially valuable for seashore planting, even standing occasional inundations of salt water. See Fruit Department. P. 25 cts. each, $\$ 2$ for 10 ; larger, 50 cts. each, $\$ 4.50$ for 10 .

ALBIZZIA LEBBEK. Woman's Tongue Tree. T. leaved shade tree which does well here. It is of quick growth, with greenish yellow flowers. Resembles the royal poinciana somewhat but leaves not so finely cut. P. Nice plants, 50 cts. each, $\$ 4$ for 10 ; larger, $\$ 1$ each.

A. PROCERA. T. Tropical Asia. A tall, quick-growing tree, beautiful, resembling somewhat the preceding. P. $\$ 1$.

ARAUCARIA $\underset{\text { ST. Australia. }}{\text { BID This is the most }}$ picturesque and tropical appearing conifer for Florida planting. It is of symmetrical growth and rounding-pyramidal form, with strong, pendulous branches from the ground up. It may be successfully grown outdoors in South Florida, withstanding severe frosts. It is frequently planted in very limited areas or close to porches and buildings, but this is a serious error, as the tree reaches enormous proportions and should only be planted in larger areas where it can be viewed from a considerable distance and appear in good perspective. $P$. Young plants, $\$ 1.50$; larger, $\$ 2.50$.

BROUSSONETIA PAPY I F E A. Paper Mulberry. H. China and A toce, 30 to 50 feet high, with downy branches and large, rough leaves resembling the mulberry. The bark is stringy and used in paper manufacture. A rapid grower, making a low-spreading head, standing heat and dust well. Quite hardy as far north as New York. Strong stock, 25 cts. to $\$ 1$.

\section{CALLITRIS verRUCOSA. Cypress Pine. ST.} valuable on the poor sand ridges of Florida where many subjects will not thrive, growing thriftily wherever the Spruce Pine is native. Its fine, green foliage very much resembles cedar, and its low, dense growth, tapering up to true cone shape, makes it especially useful in plantings amongst poor sapling pines where one wishes to get a lower ground-effect of coniferous foliage. P. Nice young stock, $75 \mathrm{cts}$. and $\$ 1.50$.

C. VERRUCOSA, BLUE. This is a splendid form of the preceding, the difference being in the color of foliage which is a stronger blue-green. Prices same as above.
CANANGIUM ODoratUM. Ylang Ylang. T. bearing a Southeast Asia. A handsome tree . yielding a fragrant volatile oil known to commerce as "ilangilang oil." P. \$1 each, \$9 for 10.

CARYOPHYLLUS JAMBos. Rose Apple. T. ularly handome medium . India and Malaya. A partictree of upright growth, also useful in border planting as a large shrub, with long, willowy green leaves. See Fruit Department. P. 50 cts. each, $\$ 4.50$ for 10 ; extra-large, $\$ 1$. CASUARINA $\underset{\text { Pine, or Bef Wood. T. While we }}{\mathrm{E} \text { U I S }}$ do not recommend this at all for general planting, there are circumstances which excuse its use, chief of which is proximity to the seashore. Here it will withstand the buffeting of wind and salt spray to splendid advantage, serving a useful purpose in itself and also making a most valuable screen for other more tender and susceptible subjects. They will grow and thrive on fresh "fills" along the coast, which are usually little more than beach sand, starting immediate thrifty growth when planted. P. $50 \mathrm{cts}$. each, $\$ 4.50$ for 10 ; larger, $75 \mathrm{cts}$. and $\$ 1$.

C. CUNNINGHAMIANA. ST. This species, closely related to the preceding, is of special value in being much more hardy and thus extending the area of the serviceable Australian Pine for seashore windbreaks. P. Small plants, $35 \mathrm{cts}$. each, $\$ 3$ for 10 .

CITRUS in variety. ST. All of this group of treessubjects for the decoration of the lawn wherever hardy, forming most attractive subjects of beautifully symmetrical roundish form, glossy green foliage, and dcep golden yellow to orange-colored fruits. See Fruit Department for varieties and prices.

COCCOLOBIS UVIFERA. Sea-grape or ShoreCOLOLE T. South Florida coasts and West Indies. If your home is along the South Florida coasts, be sure to plant several of these handsome mediumsized trees. Its foliage is large, round, veined and petioled strong red. Altogether it is one of the most beautiful trees of the Tropics and its capacity to resist salt wind and spray makes it a subject of very particular value. We recommend it highly. See Fruit Department. P. 75 cts. each, $\$ 6.50$ for 10. CUPRESSUS LUSITANICA GLAUCA. H. One of scape standpoint, valuable coniferous trees for general Florida planting, attaining 50 feet in height. It is of spreading habit, with pendulous branches clothed with glaucous green foliage. P. Strong plants, $\$ 1.50$. 


\section{SHADE TREES FOR LAWN AND PARK PLANTING, continued}

DELONIX REGIA. Royal Poinciana. T. Madagascar. An extremely rapid-growing tree, one of the fastest we know, with wide-spreading, umbrellashaped top. Foliage fine, pinnate, large, dense in summer but becoming thin during the colder months. Flowers 3 inches across and bright scarlet, make the tree one of the most striking and gorgeous in the Tropics. Blossoms spring and early summer. P. 25c, each, $\$ 2$ for 10 ; Iarger, 35c. and 50c. DILLENIA INDICA. T. Tropical Asia. Shapely leaves, giving dense shade. Flowers large and showy, fully 9 inches across, with numerous stamens forming a large yellow cluster in center. A very showy subject, related to Magnolia. The large acid fruits are used in jelly-making. P. $\$ 1$ and $\$ 2$.

\section{ENTEROLOBIUM CYCLOCARPUM. T. West} Indies. Tall, smooth tree

with handsome, feathery foliage and curious seed-pods or "beans" twisted in a complete circle. P. 75c. each, $\$ 6.50$ for 10. ERIOBOTRYA JAPONICA. Loquat. H. A

Florida planting, with large, handsome, rough leaves of striking character for the lawn of the home grounds. Grows and fruits particularly well on uncultivated ground. See Fruit Department for varieties and prices.

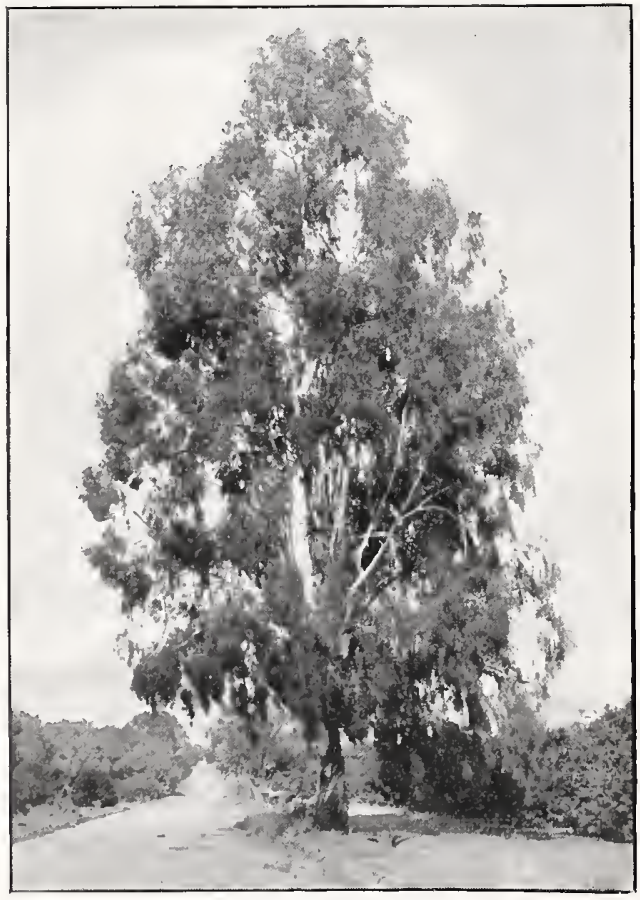

The Picturesque Euealyptus

EUCALYPTUS. Gum Tree. ST. Australia. A UCALY valuable genus of forest trees now in the public cye, bcing exploited for timber-growing in Cahifornia. Some species do fairly well in South Florida, especially on rolling or hilly, well-drained land as free from frost as may be found. Some specimens are growing well on flatwoods soil. For forests set 6 to 12 feet each way. We offer some of the very best species adapted to Florida conditions, all plants of which are pot-grown, and may be set out when weather conditions suit, especially in summer. As they are naturally very slender, pruning may bc done to bring them into any desired form, preferably in early spring.

Frankly, we do not favor the use of Eucalyptus trees for street planting, for several very well-founded reasons. For general shade trees on the small lawn we do not recommend them either, though on large properties, especially where they can be planted in groups, they can be worked into the landscape effect to very excellent advantage because of their towering, picturesque habit and growth. Their root system is extensive - and shallow-and must be guarded against when planted close to groves for windbreaks, for which they are best suited. Like the Australian pine, they stand considerable exposure along the open shores and are invaluable on fresh "filled land" where so many subjects will not thrive. They seem to take hold right off and grow vigorously without check through the cold wind and stormy weather of the winter months. They should not be planted in latitudes where they would not be hardy on account of too low temperatures.

E. ROBUSTA. Swamp Mahogany. This seems of unusual merit here, especially as a shade tree, as its spreading habit and broader leaves cast more shade than most species. P. 15 ets. each, $\$ 1.25$ for 10 ; heavier, 25 cts. each, $\$ 2$ for 10 .

E. ROSTRATA. Red Gum. This is found in more places than any other Euealypt in Florida, and the largest Eucalypt in the state is growing near Oneco. It is unusually hardy. P. 15 ets. each, $\$ 1.25$ for 10 ; larger, 25 cts. each, $\$ 2$ for 10 ; heavier, 50 cts. each.

E. RUDIS. Flooded Gum. This may be planted on low, wet lands, subject to inundation, and promises to be fairly hardy. P. 15 cts. each, $\$ 1.25$ for 10 ; heavier, 25 cts. each, $\$ 2$ for 10 ; extra-heavy, 50 cts. each.

E. TERETICORNIS. Gray Gum. One tree of this species has made the most rapid diameter growth of any Eucalypt measured in Florida by the experts of the Forestry Bureau, and is a very valuable sort to plant in South Florida. P. 15 cts. each, $\$ 1.25$ for 10 ; larger, 35 cts. each, $\$ 3$ for 10 .

FICUS AUREA. Wild Rubber. T. Native. While we urge against the use of this subject for street it for general lawn planting, even where hardy, it serves a particularly useful purpose for planting along the seashore and on fresh "filled land" where many subjects will not thrive. It makes a handsome shade tree wherever hardy, ereet and with large, dense top consisting of smooth, very dark green leaves. P. $50 \mathrm{cts}$. each, $\$ 4$ for 10 ; extra-strong, $\$ 1$.

F. ELASTICA. India Rubber Tree. T. This is the common Rubber Tree grown so much in the North as a decorative house subjeet. The tree grows to immense proportions, reaching a height of 100 feet in the Tropics, and is of widespreading habit. Because of the huge size it attains, it should only be planted on properties of large size that can adequately contain it and where it can be viewed in proper perspective. Nothing could be more absurd than the sight of a tiny town Iot dominated by so enormous a subject as this-and usually planted right close to the house! The leaves grow to 12 inches in length, are very dark, glossy green, leathery in texture. As a decorative subject it is of very easy culture and handsome appearance. P. Strong plants, about $18 \mathrm{in}$. high, $50 \mathrm{cts}$. each $\$ 4.50$ for $10 ; 3 \mathrm{ft}$., $\$ 1$ each; extra fine, $\$ 1.50$ each.

F. ELASTICA VARIEGATA. T. This is a very fine form of the Rubber Plant with creamy white margins, and of generally brighter green color. P. Strong plants, $\$ 1$ and $\$ 2$.

SIX OTHER RARE SPECIES OF FICUS, grown in limited quantity, will be named and priced on application.

GLIRICIDIA Maculata. Madre. T. Gloriously beautiful, pinkish lavender flowers

in spikes resembling the black locust, come in spring in profusion after pinnate leaves drop. A second, but lighter, bloom period comes in a few weeks with the new growth. A small or medium-sized tree. P. 25 cts. each, $\$ 2$ for 10.

ILEX OPACA. Southern Holly. H. Native. If you can

LEX reioice at the sight of a shapely tree with dark green corlet berries, then you should have one or several of these scares of your property. This is the well-known prickly-leaved Holly used so much for Christmas decorations, making a large-sized tree with short, spreading branches, forming a narrow, pyramidal head. As the trees are diecious-male or female-plant several specimens, if possible, to assure the securing of a bearing one. 2 to $3 \mathrm{ft}$, $50 \mathrm{cts}$. each, $\$ 4.50$ for $10 ; 8$ to $9 \mathrm{ft}$., $\$ 3$ eaeh, $\$ 25$ for 10 .

JACARANDA MimosæFolia. ST. Brazil. trees for South Florida planting. The foliage is very finely cut almost fern-like, summetrical and elegant. The large panicles, each bearing 40 to 90 flowers of lavender-blue, come in great numbers from April to June and for weeks the tree is a cloud of blue, P. Fine, strong plants, $50 \mathrm{cts}$. each, $\$ 4.50$ for 10 ; extra heavy, $\$ 1$ each, $\$ 9$ for 10 


\section{ROYAL PALM NURSERIES}

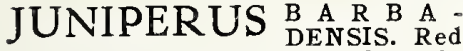
Cedar. H. Don't forget this subject when selecting your list for planting along the seashore. It is very resistant in such situations, and its dense, spreading habit makes it particularly attractive and desirable. Against a strong background of native growths it is particularly charming. Economically it has been valued for years for its beautiful red wood, much used in pencil manufacture. Because of its lasting quality, the unpeeled Cedar is to be most strongly recommended for pergola and other rustic construction. $35 \mathrm{cts}$. and $50 \mathrm{cts}$.

\section{LITCHII CHINENSIS. Litchee} nounced $L_{i}$ ght-cbee). T. China. A symmetrical, spreading tree of good clean growth and medium size, particularly valuable for lawn planting and interesting for its fruit. Most highly esteemed by oriental travelers as well as natives there. Considerably hardier than the mango and can be planted with comparative safety as far north as Tampa, especially in more protected situations. Layers from fruiting specimens, pot-grown, $\$ 3.50$; seedlings, $\$ 1.50$.

\section{MANGIFERA IN DICA.}

Tropics. Wherever hardy in lower South Florida, this subject cannot be recommended too highly for general lawn and decorative planting. A handsome, Iarge, and more or less spreading tree in Florida. Its perfect symmetry and splendid. long, tapering foliage, which when young varies in color from yellowish brown tints to deepest claret-red, make it most desirable for including in the family of trees on the lawn. Refer to Fruit Department for varieties and prices.

\section{MELALEUCA LEUCADEN-} put or Punk Tree. ST. Australia.

Far from being a "punk" tree-in spite of its cognomen-it is to be very highly recommended for general South Florida planting, and most particulariy so on the seashore, where it ranks with the eucalyptus in powers of resistance and ease with which it takes hold and "grows off" in the poorest sand "fills." In habit, it makes a towering tree, relatively slender and can be used with very telling effect for "punctuating the Iandscape" giving much the same character to the sky-line that the Lombardy poplar does in the North. The branches are pendulous and, of course, very short, the leaves narrowly oblong and tapering, and the creamy white flowers come in a profusion of roundish spikes. The bark-because of which it received its second name-is deeply spongy and of palebuff color. It thrives also on very low, wet soil around lakes and similar situations. We consider it one of our choicest acquisitions. P. Strong plants, 50 cts. each, $\$ 4.50$ for 10 ; much heavier, \$1 each, $\$ 9$ for 10 .

MORUS ALBA. Mulberry. H. Most useful tree for great objection being that it is deciduous during the colder portion of the winter months. It is an exceptionally rapid grower, of spreading habit and with large, coarse foliage, and for those who live here the year 'round and do not object to an occasional deciduous tree if their grounds are of some size, it is to be highly recommended. See Fruit Department for prices and varieties.

PARKINSONIA ACULEATA. Jerusale. $n$ Thorn. thorny tree up to $20 \mathrm{feet}$ high; branches somewhat pendulous, bearing long, narrow, pinnate leaves; deciduous. In late spring it is a mass of bright yellow flowers. It is relatively hard $y$ and thrives in the driest places. A good tree to plant in localities so dry that other trees will not thrive there. P. $50 \mathrm{c}$.
PERSEA A M E R I C A N A

"Alligator or Avocado Pear"). T.,ST. On the small lot, where space is limited there is a very special reason for making fruit trees serve the double purpose of ornament and economy and we recommend the Avocado very highly for this purpose. It makes a good spreading Iawn tree with large, evergreen foliage, bearing a salad-fruit of incomparable value. Because of the new Guatemalan and Mexican varieties, the area of safe planting of the Avocado has been extended to include the entire peninsula of the state, and we refer you to the Fruit Department for extended descriptions of varieties and prices.

\section{PITTO SPORUM}

UNDULATUM. Victorian Box. $\mathrm{ST}$. Here is a subject that is likely to prove disappointing the first two or three years when planted in the sandy soils of South Florida, but after it once gets its "second wind," so to speak, and finally makes a start, it does well and amply repays the efforts of the horticulturist who prides himself on his success with those subjects which are a "Iittle more diffcult." It makes a handsome, rather small, round-headed tree, with rich, dark green, wavy-margined, evergreen leaves. The flowers are yellowish white, small but extremely fragrant, resembling orange blossoms. P. Fine plants, $50 \mathrm{cts}$. each, $\$ 4$ for 10 .

RHEEDIA ARISTATA. T. A of very upright growth, attaining a height of 50 feet, with prickly leaves suggesting holly. While it makes a very handsome specimen in the Tropics, and may do well in extreme South Florida, the fruit is of questionable value. P. $\$ 2$

SAPINDUS MUKROSSI. Soapberry Tree. H. An attractive tree with bright green compound leaves and with seeds coated with a fatty substance used as a soap. Said to be the most valuable species for Florida planting. Deciduous. P. Strong plants, 35 and $50 \mathrm{cts}$. each. SARACA INDICA. T. India. A small, spreading tree sweet-scented flowers which change from yellow to orange and red. A very showy and attractive tree. Prefers a partly shaded situation. P. $\$ 2$.

SPATHODEA CAMPanulata. T. Tropical

large, pinnate leaves and Iarge, pitcher-shaped flowers, dull red in color with yellow border, blooming when quite small. It is very tender and suited to planting only in very protected places in extreme South Florida. P. 25 cts. each, \$2 for 10.

STILLINGIA sEBIFERA. Tallow Tree. H. This lawn planting, especially toward the northern section where deciduous subjects are not considered so objectionable. In growth it is somewhat spreading and the top is a dense mass of poplar-like leaves which turn brilliant colors in the autumn before dropping. P. $50 \mathrm{cts}$.

TAMARINDUS INDICA. Tamarind. T. Tropspreading shade tree with fine-cut, feathery foliage, growing along the low ridges and hillsides in the Tropics. Frequented for its inviting shade as well as for its tart fruit. P. 50 cts.

TRISTANIA AUstralis. T. Australia. A tallin South Florida. The yellow flowers are produced in summer. P. $\$ 1$. 

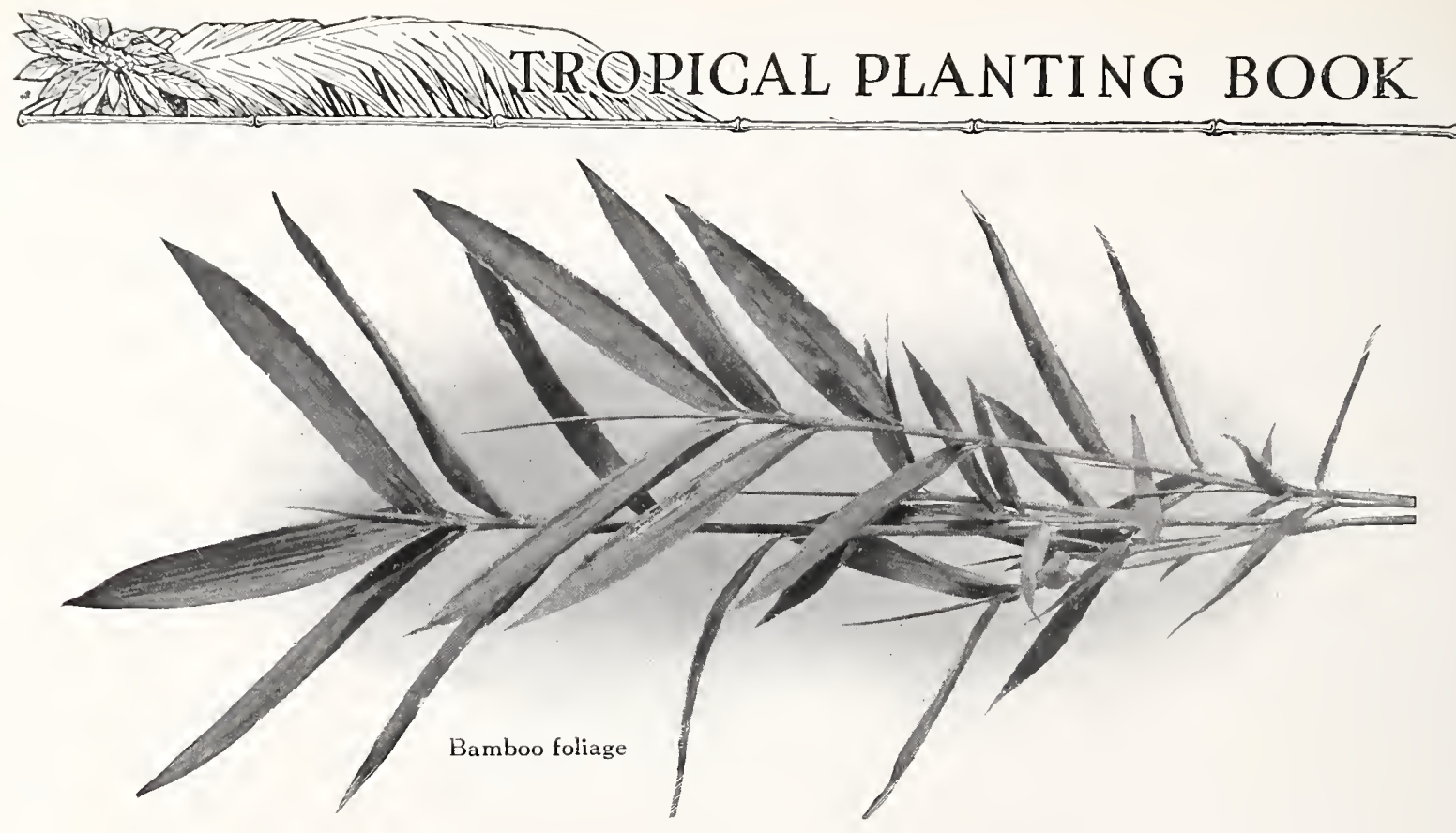

\title{
Bamboos and Grasses
}

\begin{abstract}
"Strong, yet graceful; single, yet bow prolific in its multiplicity of canes; silent, yet speaking with countless tongues of the beauty and appeal of our Southern Paradise!"
\end{abstract}

$\mathrm{T}$

HE name "Bamboo Tree" is a misnomer in every sense of the word, though in lawn decorative practice the Bamboo is frequently used in place of trees. In a limitcd way it does serve the same purposesto add interest and variety to the sky-line, to cast long shadows of varied form in the early and late hours of the day, and to add a feeling of enclosing bulk to the proportion of the planting as a whole-but its more especial usefulness in the South rests in the distinctively tropical effect it creates in the landscape.

It is entirely unique in its habit of growth, being a bunch of grass of monumental proportions, and placed in proper relation to the surrounding plants and landscape, it is coequal with the palm in its power of suggesting the fascination of the Tropics. There are several of the more hardy sorts which are cffective as far north as Ohio and Pennsylvania, where they stand the winters safely and where liberal plantings create a luxuriant and semi-tropical effect. For the florist, the Bamboos proper are especially useful in many waysdecoration, design work, and the like.

But it is in the South that the Bamboo is particularly useful because there it reaches its perfection, and yet, with so many desirable features to commend it to Florida planters and horticulturists, it has, unfortunately, becn much neglected. While effective as an individual if properly handled, yet it is preëminently fitted to massed groupings when used in conjunction with ornamental grasses as border plantings with agaves, yuccas, and the like for contrast at points to bring out the fountain-like character of growth. But when uscd as single ornamental specimens, Bamboos, like large coniferous trees, are seen to best advantage when at some distance where they have sufficient space to appear in proper perspective to the surrounding plantings.

While they do well on quite a wide range of soils, they do not like very thirsty land and, as gross feeders, respond readily to libcral applications of organic manures and fertilizcrs. When used for hedge and windbreak purposes, they can be planted very close together and in a few years are effective and truly invaluable. Objection is sometimes raised on the score of the foraging powers of the root system, which endangers the growth of nearby trees and plants, but this can be offset by shallow ditching.

Special Notice. Grasses and Bamboos may be set out any time of the year. On a large scale of planting,

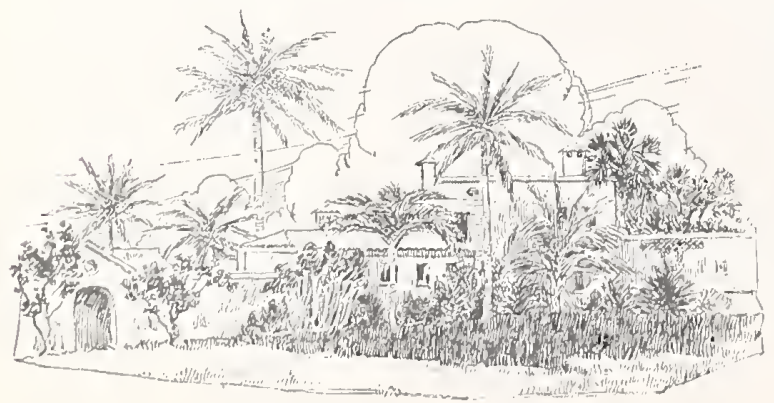
summer is to be preferred or late spring in this climate. For northern and western locations, we should recommend the spring. See note under Lawns for special remarks on lawns.

Explanation of Symbols. * Those most hardy, standing the climate as far north as Ohio or farther. ** Hardy all along the Gulf Coast, standing a temperature as low as 12 or 15 degrees Fahr. without scrious, if any, injury. *** Tropical species, withstanding but light frosts unharmed. Roots will throw up growth, however, if tops are frozen. 


\section{ROYAL PALM NURSERIES}

\section{Group I. Giant-caned Species of Bamboos}

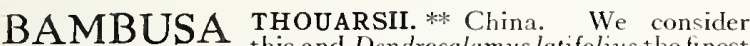
A this and Dendrocalamus latifolius the finest Giant-caned Bamboos for peninsular Florida. While not quite so large in cane as $B$. vulgaris, they are of mich better color and much more dense and compact, making towering specimens of incomparable beauty. This was introduced by us to Florida not many years ago and is growing splendidly on our grounds now. It has withstood 20 degrees Fahr. with no injury whatever. Erect and vigorous in growth, it promises to reach 50 to 60 feet in height at least. Strong young plants, $\$ 2.50$ each; small clumps, $\$ 5$; larger clumps, $\$ 10$.

B. VULGARIS. Giant or GoIden Bamboo. *** Now quite commonly grown over South Florida. One of the handsomest of the genus, reaching a height of 60 to 70 feet, light yellow in color, and making great clumps of arching, feathery canes. Prices on application.

DENDROCALAMUS LATIFOLIUS. ** Like

giant-caned type, this one is especially valuable for creating sky-line effects of tropical character and for decorating the shores of lakes, ponds, streams, and the like. The particular merits of the Bamboo itself, however, are the color of its foliage, which is a very dark green, the size of the individual leaves, as its specific name indicates, and its hardiness, withstanding sharp freezes unharmed. Altogether a very rare and valuable plant, and useful in the Florida landscape. Size and price on application.

D. STRICTUS. **** A lovely Giant-caned Bamboo of great charn for its airy, feathery eflect, accentuated by its very yellow-green foliage, and particularly useful from the landscape standpoint for Iightening up an otherwise dark and somber background. It will stand more frost than most of the tropical Bamboos and the canes, which are solid until quite large, attain a height of 40 to 50 feet. 50 cts. to $\$ 15$.

PHYLLOSTACHYS QUILIOI. Timber Bamboo. sider this of relatively little value for landscape purposes because of the irregular, scattered character of its growth, it is particularly interesting and valuable for its gigantic stems which attain a diameter of 4 inches and a height of upward of 70 feet. These arise from underground rootstalks usually about 2 feet apart and nraking a loose, spreading plantation. $\$ 1$.

\section{Group II. Species of Bamboos Making Thick Clumps of Small- to Medium-sized Canes}

BAMBUSA ALPHONSE KARRI. ** Japan. This species makes huge clumps of strong canes which are striped alternately green and yellow in distinctive marking. In growth it is vigorous and suggests $B$. argentea striata. Clumps, 50 cts., $\$ 1, \$ 1.50$, and $\$ 2.50$.

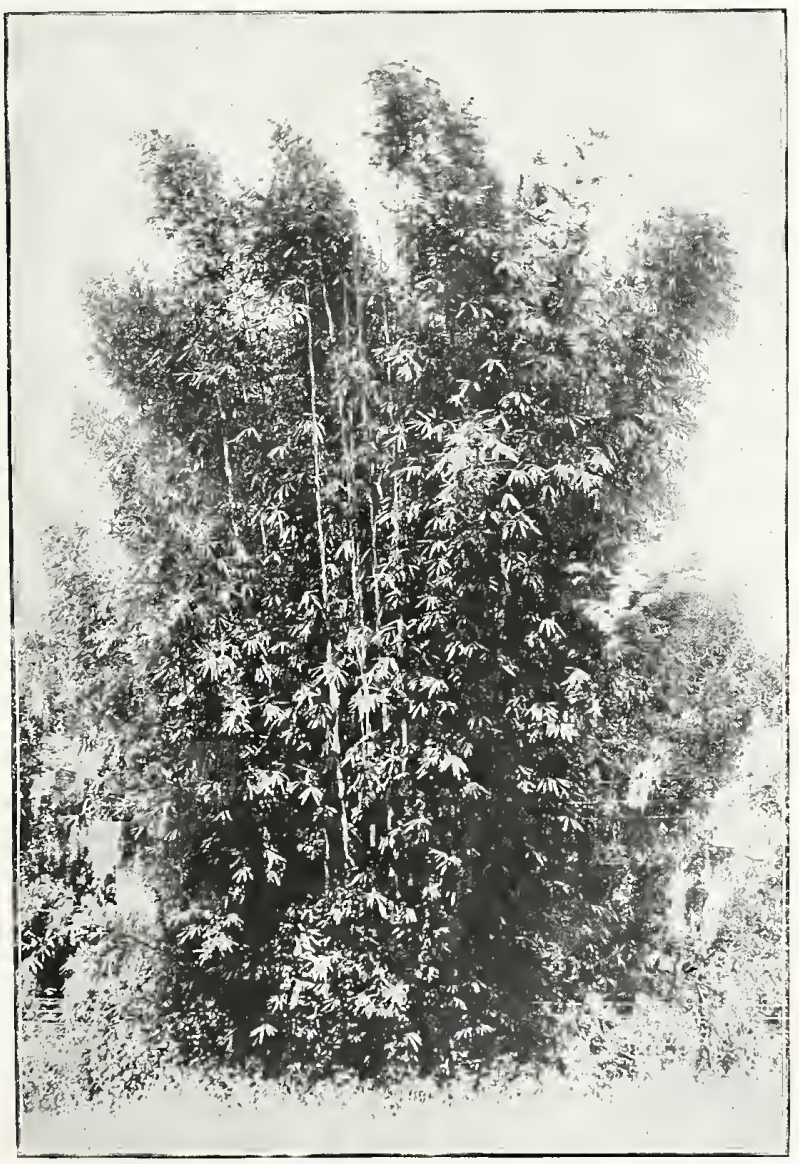

Bambusa thouarsii
B. ARGENTEA. ** Japan. A particularly attractive species, making dense clumps of relatively small canes which are very graceful and clothed with small foliage. It reaches a height rarely exceeding 30 feet or so and is valuable for hedge or windbreak purposes. Single cines, rooted, 15 cts, eich, $\$ 1$ for $10, \$ 8$ per 100 ; clumps, 35 cts., $\$ 1, \$ 2.50, \$ 5, \$ 10, \$ 15$, and $\$ 25$.

B. ARGENTEA STRIATA. ** Like the preceding except that the foliage is striped white, especially during period of most rapid growth, and the canes are considerably larger and more vigorous than the tvpe. Extra valuable subject for windbreaks and for planting along margins of our inland lakes. Single canes, rooted, $25 \mathrm{cts}$. each, $\$ 2$ for 10 , $\$ 15$ per 100 ; clumps, 35 cts., $\$ 1, \$ 2.50$, $\$ 5, \$ 10, \$ 15$, and $\$ 25$.

B. DISTICHA. ** A rather dwarf Bamboo reaching a height of 10 feet and forming dense clumps particularly striking when combined with ornaniental grasses. Foliage extremely small and narrow. Individual canes with their foliage are effective in decorations and may be used by the thorist. This form is particularly valuable for making hedges or screens from 6 to 10 feet high, for which purpose it is unexcelled under conditions permitting the use of bamboo at all. Single canes, rooted, 25 cts. each, $\$ 2$ fo 10 ; clumps, 50 cts., $\$ 1$, and $\$ 2.50$.

Group III. Species of Small-caned Bamboos Spreading Irregularly and Making Thickets and Screens

ARUNDINARIA METAKE. Arrow Bamboo. leaved, hardy species, rarely exceeding 10 feet in height, very suitable for tubs as a house-plant. It forms naturafly large masses but may be confined to clumps effectively Because of its loose, spreading habit by underground bhoots, its usefulness in landscape work is extremely limshoots, its usefulness in landscape work is extend it, and on ited, for which purpose we seldom recomnend it, and on small properties it may actually become a nuisance. Single canes, rooted, $10 \mathrm{cts}$. each, $85 \mathrm{cts}$. for 10 ; clumps, 25 and $50 \mathrm{cts}$

PHYLLOSTACHYS AUREA.* Japan. Very hardy species with un-

derground running stems which throw up canes irregularly. Unless confined it makes a straggling appearance. Fine for tubs or for odd places on large grounds, making a fine "cover" for poultry; prefers a good, moist soil. Hardy fine "cover" for poultry; prefers a good, nroist soil. Hardy to the Ohio River at least. Attach, $\$ 2$ for 10 ; heavy plants, 1 to 4 stalks, 50 cts. each, $\$ 4$ for 10 . 


\section{Group IV. Ornamental Grasses}

Nothing could be more attractive around the margins of our Florida lakes-or elsewhere for that matter-than groups of the following Grasses, especially when supported by clumps of bamboos. Their delicate foliage harmonizcs and blends perfectly with the soft ripples of the water, and most charming effects have thus been creatcd.

ARUNDO DONAX VARIEGATA. Gardener's Garheight of 12 feet, beautifully variegated with white, especially during its early growth. Makes large clumps and is useful for bedding. Has immense flower-plumes. Espccially hardy and may be planted all over the Middle States as well as the South. When the canes pass their period of greatest beauty they may be cut to the ground, in this way forcing the growth of new variegated canes. Heavy roots, 35 cts. each, $\$ 3$ for 10

CORTADERTA SElloANa. Silver Pampas Grass. C I Too much cannot be said in praise of this splendid grass which in years makes huge clumps of fine foliage. In the fall it produces beautiful plumes of silvery color, often 2 feet long, which last for weeks. It is especially desirable for use with massed clumps of bamboos, other ornamental grasses, agaves, and the like. Clumps, $50 \mathrm{cts}$. and $\$ 1$.

\section{CYMBOPOGON CITRATUS. Lemon Grass. ***} India. This makes clumps of citronella and may be valuable as a money crop on South Florida lands. $15 \mathrm{cts}$. each, $\$ 1$ for 10 .
CYPERUS ALTERNIFolius. Umbrella Grass. ** An unusual and attractive grassy subject, with long stems surmounted by expanded foliage somewhat suggesting an umbrella. It makes an attractive subject for border planting with bamboos and other grass-like materials on moist soil, but its great charm is best displayed when grouped in masses along the banks of streams, ponds, Iakes, and in formal gardens near pools. It never reaches its artistic perfection without the proximity of water. $35 \mathrm{c}$. each, $\$ 3$ for 10 .

C. PAPYRUS. Egyptian Paper Reed or Moses' Bulrush.** Here is the subject par excellence for planting at the edge of fresh water, or actually within its limits if shallow. The plumy nuasses of long, thread-like leaves are borne on the ends of triangular stems, exceedingly graceful. Forms large clumps 6 to 10 feet tall on good rich soil. $50 \mathrm{cts}$. each, $\$ 4$ for 10 .

PANICUM PALMIFOLIUM. Palm Grass. ** A few clumps of this should be on every property of any size as it is invaluable for grassy borders, for limited use against stone or cement work of any kind, and the like. It is of exceptionally vigorous growth, producing long, arching, graceful leaves that very closely resemble those of palms in the young or "seedling" stage-hence its name. Good clumps will grow to a height of 6 feet in a single summer season, which is an added merit when considering quick effects. $25 \mathrm{c}$. each, $\$ 2$ for 10 .

\section{Group V. Lawn Grasses, Etc.}

Good Iawns in Florida are far less common than in the North-they are more difficult to build up and to maintain, largely because of the character of our average sandy soils. However, very fair lawns can be had on most soils with a little special attention in respect to fertilizing and watering. Florida has three very good lawn grasses, all grown from "cuttings" as a rule, as either they do not perfect seed or seeding is not generally successful. Unless in a hurry to secure a heavy sod, we recommend planting the "cuttings" about a foot apart each way, in which case a bushel of St. Augustine sets about 800 cuttings and of Bermuda and St. Lucic about 1,500 cuttings. These grasses can be planted separately or one can alternate the varieties in the rows and "let the best man win." Of course, the ground should rcceive some advance preparation - if raw land, it should be thoroughly grubbed and all oak and other roots removed, and then plowed and harrowed down to good tcxture as well as being fertilizedpreferably with some good dairy or stable manure or, if not that, with commercial fertilizers of organic base. Good black soil, rich in humus, makes an excellent supplementary planting material, but on dry soils this application should not be of raw muck-applications of the latter will frequently ruin the prospects of a good lawn. Lime is a valuable corrective of acid conditions and after the planting the lawn should be maintained with applications of commercial fertilizer, sufficient to keep the grass growing well.

CAPR IOL A DACTYLON. Bermuda Grass. ** This is CAPRIOLA DACTYLON. Bermuda Grass. common everywhere. Wc merely list it for the convenience bothered securing it locally. It is the best grass to make a solid sod on which to plant the Italian Rye Grass for winter lawn-for this purpose we recommend a mixture of 80 per cent

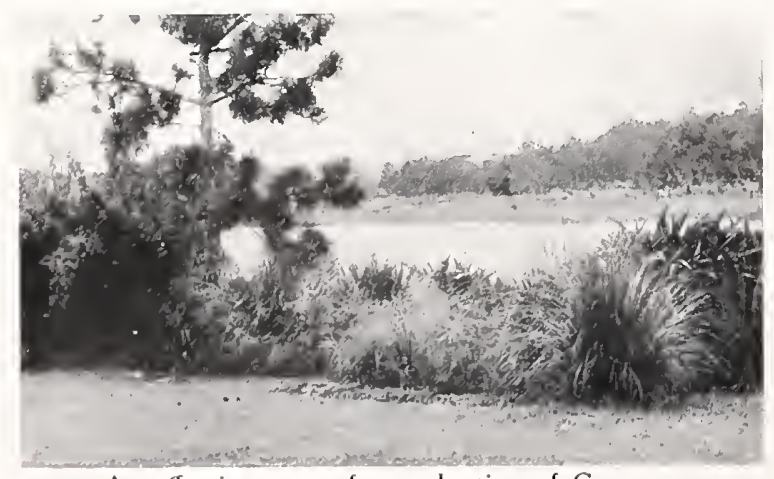

An effective water-front planting of Grasses
Italian Ryc sced and 20 per cent Red Top, sown right on the Bermuda sod about two wecks prior to date you wish lawns to begin to look their best. Bv proper attention to mowing and watering you can have a splendid carpet of green grass until May. Bushel $\$ 1.25$, by express.

C. DACTYLON, variety. St. Lucie Grass. ** This is one of the favorite lawn grasses of South Florida, of fine texture like Bermuda Grass, but making a heavy mat on the surface and not deeply rooted like the latter, and thercforc much simpler to eradicate. It grows quickly from surfacc runners, but as it seldom perfects secd, must be grown from bits of sod. Clean sod, soil removed, bushel $\$ 1.50$, by express only; small lots, 25 cts. and upward.

STENOTAPHRUM SECUNDATUM. St. AuRustine Grass. ** A splendid coarse-tcxtured lawn grass which with proper attention makcs a thick, springy sod preferred by many. Another special value is its ability to withstand the adverse conditions in the shade of large trees and thrives on a wide variety of soils. 50 cts, per 100 cuttings, $\$ 1.50$ per bushel by cxpress.

PANICUM MOLLE. Para Grass. ** One of the grcatcst forage grasses for Florida and the

Gulf Coast. Will grow on very indiffercnt soil, wet or dry, and produce wonclerfully. Scldom perfects sced and is grown by plowing under the growing tops, preferably in the rainy scason. Cut tops, by express, 50 cts. for $20 \mathrm{lbs}$., $\$ 2$ per $100 \mathrm{lbs}$.; roots, 35 cts. for 10 . Special terms for largc quantities. 


\section{ROYAL PALM NURSERIES

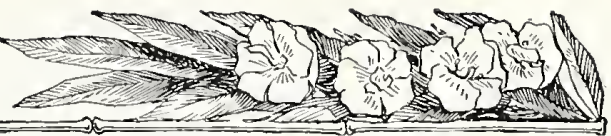

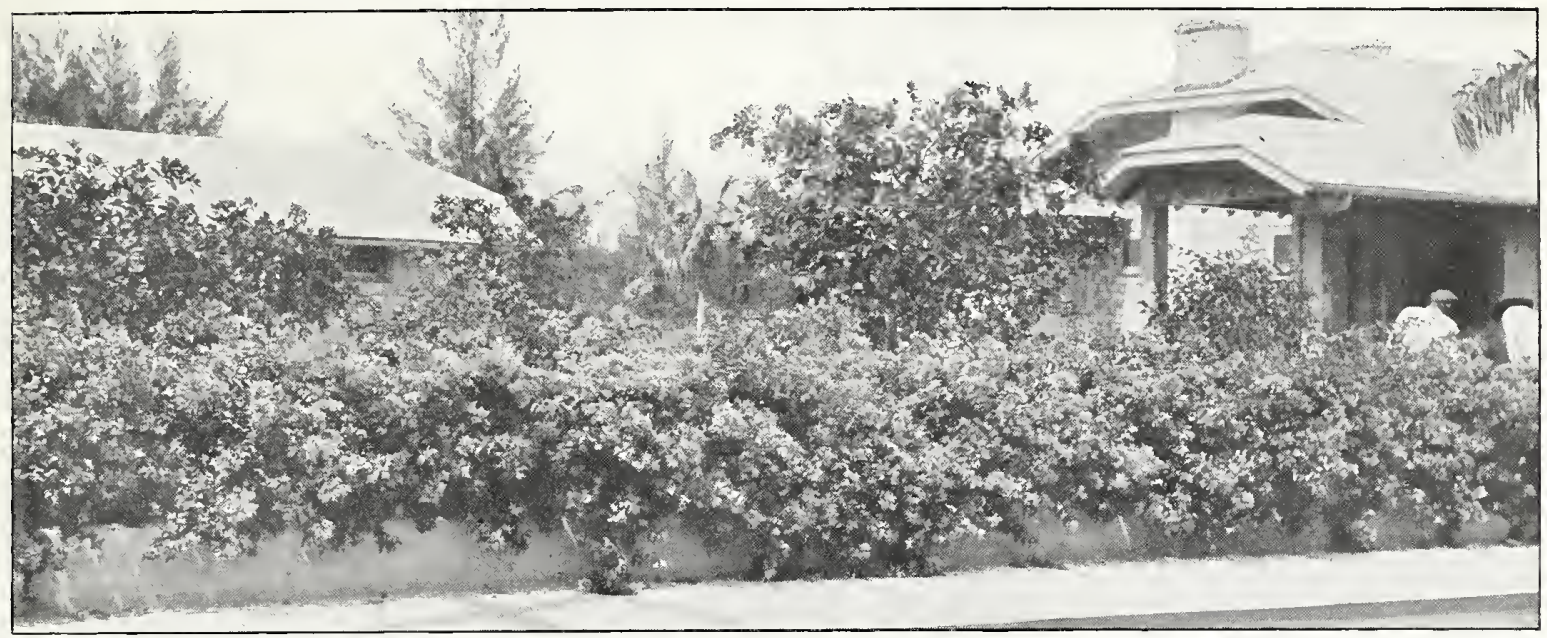

A gorgeous border planting of Bougainvillea glabra sanderiana. A riot of color all the year

\section{Flowering Plants and Shrubs}

$\mathrm{T}$

HE GEM without its setting is still a gem-yet consider what it loses in effeet. And a house or just a speeimen tree or palm without flowering and ornamental shrubs is like that-a gem without setting-a pieture without a frame. How many homes we see costing thousands of dollars that stare obtrusively into the publie eye-they have none of that atmosphere of good taste and refinement so expressive of wellrounded personality and eharaeter. There they stand, piles of briek or stone or wood, without any serious effort to add that eloquent toueh of simple dignity that well-ordered planting ean give. Sometimes there are a few plants set out at random-some ragged ferns and an expressionless geranium or so-but no studied attempt at ereating a real pieture of the home. Of eourse, the trained landseape artist can seeure better effects than ean the person of inexperience-that would be expeeted. But a little good taste goes a long way when in eonjunetion with a real desire to aeeomplish something, and if the home owner will give a very little thoughtful attention to the earlier pages of this book on Iandseaping, as weIl as the remarks at head of departments, very satisfaetory results ean be obtained. And always keep before you this primary objective-purpose. Don't have a few meaningless speeimens, forlorn and Ionely, everlastingly flaunting their charms before a sophistieated audienee-but make them serve a purpose in securing pieturesque effects. Don't eonsider the plants for themselves, but refleet on what way they ean serve in building up a picture.

While there are frequently points at whieh only a single speeimen shrub will serve, as a rule it is better to lean toward mass planting. It will be wise to avoid setting out a few exotie pets around the lawn at random; remember that every time you break up your lawn with speeimen shrubs you are foreshortening your foreground; at times this is permissible, but be sure that this is the ease before you do so. It is preferable and safer to pile up your shrubs in heavy borders around the eonfines of your grounds to give them better definition and to soften the larger angles with whole "families" of shrubs as the size of the grounds permits. Where you want eolor-use it. Make great splashes if need be to get the effect toward which you are working. If you are limited to the number you ean use, either reduce the area of your pieture or inerease the open area in the eenter-but use what you have to plant, in mass formation. Where you need baekground, build it as nature would, with lavish abandon, ereating a truly natural effeet. And don't forget your sky-line—remember that you are planning for years to eome.

As a help in eolor seleetion, the following elassification will be found useful: the ehief purpose of this booklet is to help in securing better gardens for Florida. The greater the degree of assistanee we ean render, the eloser our work approaehes the ideal we are striving to attain. In this work we trust that we ean count on your eoöperation-without it our objective will be impossible of attainment.

\section{Suggestive Color Classification of Flowering Shrubs}

(A) RED SHADES.--Acalypha hispida, Cæsalpinia, Hamelia, Hibiscus, Jacobinia, Azalea, Lawsonia, Russellia, Camellia, Lagerstrœmia, Callistemon, Nerium, Lantana, Sesbania, Malvaviscus, Rose, Punica, Poinsettia.

(B) PINK SHADES.-Abelia, Assonia, Bauhinia, Hibiscus, Lantana, Azalea, Camellia, Hydrangea, Rhodomyrtus, Lagerstrœmia, Nerium, Melastoma, Rose.

(C) YELLOW SHADES. - Allamanda, Artobotrys, Carica, Cestrum, Hibiscus, Hypericum, Lantana, Stenolobium, Thevetia, Acacia, Jasminum, Leonotis, Michelia, Nerium, Rose.

(D) BLUE TO PURPLE.-Azalea, Bauhinia, Bougainvillea, Dædalacanthus, Duranta, Hydrangea, Lagerstrœmia, Lantana, Plumbago, Strobilanthes, Tibouchina, Thunbergia.

(E) WHITE.-Bauhinia, Carissa, Cestrum, Chalcas, Datura, Jasminum, Lantana, Azalea, Oxyanthus, Thunbergia, Lawsonia, Tabernæmontana, Warneria, Camellia, Hydrangea, Ligustrum, Laurocerasus, Coffea, Pittosporum, Rose, Tetrapanax, Vinca, Viburnum, Raphiolepis, Melaleuca ericifolia, Plumbago. 


\section{Bear Attractive Berries or Fruits}

Chalcas, Duranta, Hamelia, Laurocerasus, Carissa, Coffea, Kumquats, Elæagnus, Triphasia, Baccharis, Cestrum, Ilex, Eugenia, Lonicera, Lycium.

\section{Special Notice. Nearly all plants in this dc-} may be transplanted at any time of the vear, though in Florida we prefer spring and summer. The exeeptions are so noted in descriptions and should be handlcd during the cooler months, say from November to March. Those shrubs marked $T$ are in the tropieal elass and should only be planted within the confines of this state and the Tropics, or other proteeted situation, or for use in eonservatory or house deeoration. In Florida, generally, when frozen they are just eut to the ground and most sorts will come baek vigorously and flower the same ycar. Those marked $H$ arc hardier and will stand the winters of the lower South without injury, or, if damaged by freezes, will come up again vigorously in the spring. All are evergreen execpt Hydrangea, Lagerstroemia, and Sesbania.

The subjects listed in this department are suitable for use in greenhouses and conservatories and in some instanees ean be grown as pot plants in living-rooms, but their speeial value is, of eourse, for planting out in open ground in the extreme South and the Tropies. In the subtropical zone, where there is danger of freezing, the stems should be banked somewhat, at first signs of hard frost, to prevent freezing to the ground-as a rule tropieal shrubs eome baek quiekly after being frozen down and flower the following summer as usual.

\section{For Shady Situations}

Try Azalea, Camellia, Severinia, Ligustrums, Hamelia, Hydrangea, Raphiolepis.

\section{For Winter or Early Spring Flowering}

Acalypha hispida, Assonias, Acacias, Bauhinias, Bougainvilleas, Cestrums, Dædalacanthus, Azalea, Hibiscus, Lantana Laurocerasus, Jasminums, Plumbagos, Russellia, Strobilanthes, Tabernæmontana, Camellia, Stenolobium sambucifolia, Roses, Thunbergias, Pittosporum, Michelia, Tetrapanax, Malvaviscus, Ráphiolepis, Cæsalpinia, Ixora.

\section{For Mucky, Rather Moist Soils}

Don't forget Oleanders, Azaleas, Myrica, Rhodomyrtus, Guavas, Baccharis.

\section{For the Seashore}

This is partly a local matter, depending so much on the partieular eonditions and amount of exposure in each individual situation. However, the following have all bcen found quite resistant to salt spray and wind to a greater or less degree, and we suggest that those living elose to salt water give them a tryout:

Acalypha, Oleanders, Thevetia, Sesbania, Hibiscus, Guavas, Ixora, Lantanas, Dwarf Poinciana, Crotons, Datura, Carissa, Elæagnus, Lagerstrœmia, Acacia, Pittosporum tobira, Callistemon, Myrica, Severinia, Triphasia, Baccharis, Forestiera, Cestrum diurnum, Lycium carolinianum, Schinus.

\section{For Fragrance}

Every garden should make some special feature in this and nothing exceeds in faseination a few night-fragrant shrubs in a moonlit garden. We suggest the following:

Artobotrys, Assonia, Chalcas, Acacia, Bauhinias, Cestrum, Datura, Duranta, Coffea, Abelia, Jasminums of course, Lawsonia, Oxyanthus, Stenolobium, Tabernæmontanas, Warneria, Laurocerasus, Roses, Michelia, Nerium (especially Splendens and Madonna grandiflora), Pittosporum, Viburnum, Carica, Raphiolepis.

\section{Group I. Especially Suitable for House Foundation Work}

The planting of the foundation of the home should be the first eonsideration when dealing with shrubs, as an unplanted house is most eonspieuously unattraetive. And the faet that a certain shrub will in years attain a height of 6 to 8 feet, or even more, should not debar it from this use if it is otherwise suitable- keep it down with annual pruning, which should be done anyway around any well-ordered home. As a rule, the plants of small- to medium-sized foliage, and those with a more or less drooping tendeney, are to be preferred, though around large publie buildings this rule need not be so rigidly applied. Remember that long lines of a building can be beautifully cmphasized by long, straight plantings and broken lines brought out by broken group plantings. Depressions can be made more effeetive and corners swelled by appropriate planting, and the various features that make the real eharacter of the building ean be very strikingly aecentuated if properly handled.

The following list is not eomplcte bceause there are so many situations requiring individual treatment; we make this elassification as a help to those in doubt. Experieneed planters will, of eourse, be guided by their own judgment; their list would inelude many more than we indieate because thcy appreeiate better the usableness of all shrubs with whieh they are familiar.

ABELIA Grandiflora. Abelia. H. A very satisfactory evergreen shrub with long, willowy growtl. Foliage turns a pretty metallic bronze in winter. Flowers tubular, white with pink base, delicately scented, freely produced in clusters from April to November. Nice stock in 4-inch pots, 35 cts. each, $\$ 3$ for 10 ; strong, field-grown stock, 75 cts. each, $\$ 6.50$ for 10 .

CHALCAS PANICULATA. Orange Jessamine. T. lieight of 10 to 12 feet, with dark green, glossy compound

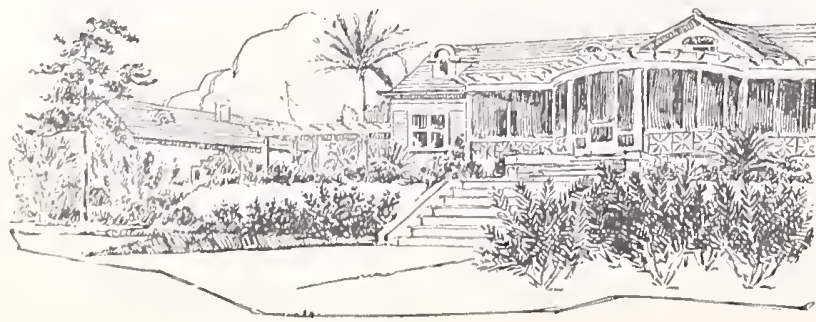

leaves and campanulate, fragrant white flowers resembling orange blossoms, coming several times a year. Does splendidly on the "sand hills" of Polk County. 35 cts. each, $\$ 3$ for 10.

DURANTA plumieri. Golden Dewdrop. T. See page 26 for description.

EUGENIA uniflora. See page 24 for description.

FORESTIERA PORULOSA. Florida Privet. T. An evergreen shrub resembling a smallse growth, thriving very close to the seashore, withstanding salt spray well. $35 \mathrm{cts}$. each, $\$ 3$ for 10 .

JASMINUM PRIMULINUM. H. China. One of blooming in early spring and hardy as far north as Washington. A drooping shrub with attractive foliage and beautiful golden yellow flowers as large as a half dollar, opening flat, scented, blooming in long sprays and when cut, keeping in water indefinitely. An exceedingly valuable shrub or vine. 35 cts. each, $\$ 3$ for 10 ; larger, $50 \mathrm{cts}$. 


\section{ROYAL PALM NURSERIES}

JASMINUM PUBESCENS. ST. While this woody plant can be used as a vine if given support, it is much more frequently used as a shrub. Its especial value is for banking against housc foundations, especially those of dark tones, and for low bedding work in the little formal touches around buildings or other structural features. The prominent white flowers are borne in profusion periodically throughout the year. Strong stock, $35 \mathrm{cts}$. each, $\$ 3$ for 10; heavier, $50 \mathrm{cts}$.

J. GRACILLIMUM. Star Jessamine. ST. Resembles the preceding, except in the structure of flower, whicl is narrowpetaled and distinctly star-shaped. Prices same as for $J$. pubescens.

\section{LA WSONIA INERMIS. Henna}

Solomon. T. East Tropics. A handsome, upright shrub of open, airy leaf texture and light in color tone. The very fragrant white flowers are produced in profusion in small spikes. Altogether a very charming subject that succeeds on a variety of soils, even the high sandy ridges of south-central Florida where it does especially well. 75 cts.

L. RUBRA. T. Similar to preceding form except the petals are dark coral-red. One of our recent introductions. Strong plants, 75 cts.

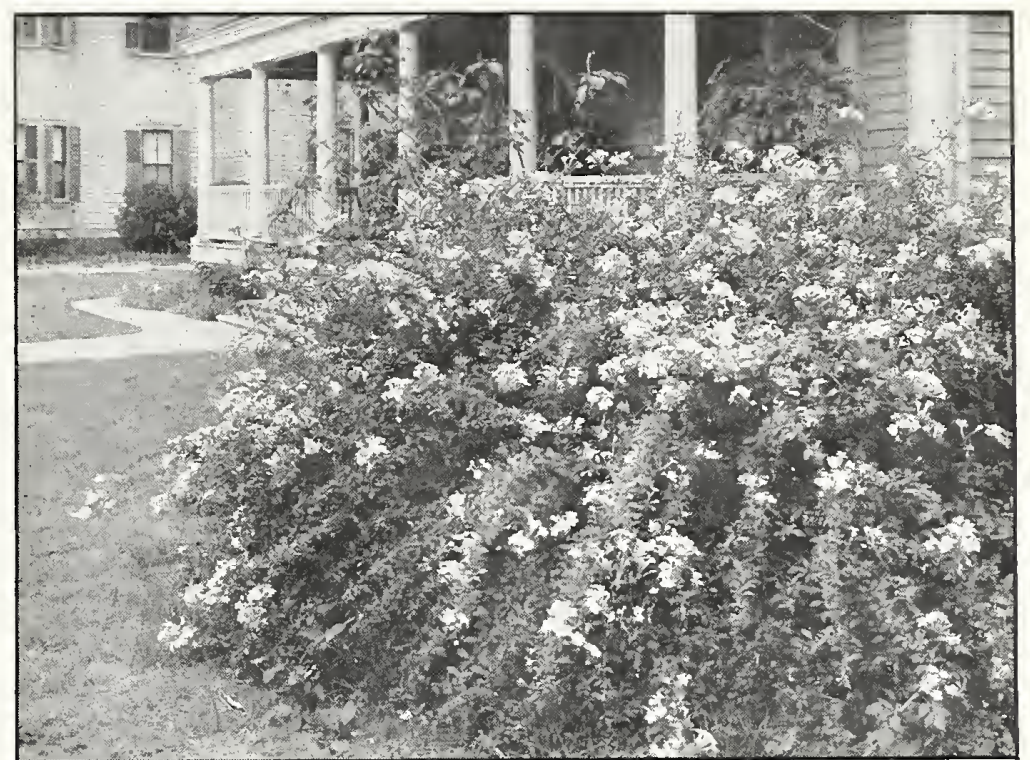

Plumbago capensis. Valuable all-the-year-round shrub. Sets off a yellowbrick house to perfection
LIGUSTRUMS. See page 24 for description.

PHYLLANTHUS NTis is a particularly desirable shrub for use in plantings against brick and masonry structural work and general foundation work of aIl sorts. The leaves are soft in texture and a rich warm purplish brown or bronze coloring, according to condition and exposure to sun. $50 \mathrm{cts}$. each, $\$ 4.50$ for 10 .

PITTOSPORUM tobira. See page 24 for description.

PLUMBAGO CAPENSIS. Blue Lead wort. T. South Africa. This is one of the showiest and most satisfactory of flowering shrubs for southein Florida bearing almost constantly a wealth of phlox-like flowers of light sky-blue color. Foliage small, soft, and light green. Very attractive. 35 cts. each, $\$ 3$ for 10 ; heavicr, 50 cts. each.

P. CAPENSIS ALBA. White Leadwort. T. Same as preceding except flowers are pure white and growth somewhat more vigorous. $50 \mathrm{cts}$.

\section{RHODOMYRTUS TOMENTOSUS. Downy}

semi-hardy shrub, growing 6 to 10 feet high, of great value for South Florida, where it grows freely on almost any soil, especially wet, flat woods. The foliage effect is gray to olivegreen, and the rosy pink flowers, suggesting wild roses in color and form, come in quantities in late spring and early summer, followed by edible blue-black berries. See Fruit Department for description of valuable fruit. $35 \mathrm{cts}$. each, $\$ 3$ for 10 ; larger, $50 \mathrm{cts}$. each, $\$ 4$ for 10 .
STROBILANTHES ANISOPHYLLUS. T. A leaves producing countless lavender flowers in winter and early spring. Makes an excellent pot plant for house or conservatory. $35 \mathrm{cts}$.

S. ISOPHYLLUS. T. A small-growing border plant reaching a height of not over 3 feet, with purplish blue flowers suggesting the petunia in appearance, about $1 \frac{1}{2}$ inches across. Valuable for edging along foundations and use in formal gardens, and the like. 25 cts. each, $\$ 2$ for 10 .

THUNBERGIA ERECTA. T. West Africa. One of the very finest of foundation-

plant subiects for Sout $\mathrm{h}$ Florida planting. It makes a dense shrub 4 to 5 feet high with most attractive, smooth, dark green leaves. It bears continuously throughout the year gloxinialike flowers 2 inches across with dark blue corolla and orangecolored throat. It is particularly charming in foliage texture when combined with Jasminum pubescens. $35 \mathrm{cts}$. each, $\$ 3$ for 10 ; larger, 50 cts. each.

T. ERECTA ALBA. T. The same as the foregoing except that the flowers are a trifle smaller and white with yellow throat. $35 \mathrm{cts}$. each, $\$ 3$ for 10 ; heavier, $50 \mathrm{cts}$. each.

VIBURNUM SUSPENSUM. (V. sandankwa.) H. spreading habit with large, dark green, elliptical leaves with scalloped edges. The fragrant flowers are cream-colored and borne in clusters. This makes a shrub some 8 to 10 feet high, though may be easily kept down to any desired height that is suitable. It makes a comparatively dense growth of horizontal wood, and we believe will prove to be a suitable subject for shearing into formal hedge. $\$ 1$.

\section{Group II. Valuable Subjects for Sheared Hedges of Formal Character}

Properly used, the formal hedge is invaluable for certain situations, as, for example, bordcring a grassed alley on either side and backed by towering shade trees, or rows of fruiting orange trees, or for enclosing the formal garden, or delineating property lines of smaller places under certain conditions. But the shearcd hedge is sometimes overdone, when it can be obtrusively out of place-some places are over-hedgcd. In planting the hedge it is best to trench the ground at least 2 feet wide and 18 inches deep, and on poorer soils that need building up the trench should be larger. Liberal applications of rotted manures should be made and thoroughly spaded in, and the plants should be set quite close in order, not only to get quicker effect, but what is more important, to better keep the hedge within proper bounds. The exact distance will depend on the subject used and the size hcdge desired-which depends on the effect sought. We suggest the following as being especially desirablc: 
PLANTS AND SHRUBS FOR SHEARED HEDGES, continued

CHALCAS paniculata. T. See page 22 for description.

EUGENIA HoOKERIANA. Bush Cherry. ST. (?) Auspromising shrubs that we have added to our lists for a long time. Just how hardy it will prove is still a matter for conjecture, but we know that it is not in the tropical class and probably it will prove sufliciently hardy over most of the state for general planting. It makes a large shrub, horizontal branching, with glossy green elliptical leaves about $21 / 2$ inches long, and bearing attractive red fruits. $50 \mathrm{cts}$. each, $\$ 4.50$ for 10 ; larger $\$ 1$ each.

E. UNIFLORA. Surinam Cherry. T. If you wish a low- to medium-sized hedge of compact growth, small foliage, and one that will shear to perfection, use this. For bordering small grass-plots, edging around formal garden areas, and the like, it is without a peer wherever sufliciently hardy. See Fruit Department. $25 \mathrm{cts}$. each, $\$ 2$ for 10 ; larger $35 \mathrm{cts}$. each.

FORESTIERA porulosa. See page 22.

ILEX PARAguayensis. Yerba Maté. H. (?) South America. With Eugenia bookeriana, we consider this one of our most valuable additions made to the shrubs of the state in a long time. Just how hardy it will prove to be here we do not know, but feel safe in recommending it to South Florida generally and suggest it for trial to all growers on the peninsula. It makes, ultimately, a large-sized shrub, is of very vigorous growth, fairly compact, with most attractive rough foliage, olive-green above, light green beneath. Pruning does not impair its growth or vitality whatever, only serving to make it more dense and attractive. The tiny flowers are pendant from the branches and are followed by small, dark, amber-colored fruits. 35 cts. each, $\$ 3$ for 10 .

\section{LAUROCERASUS CAROLINIANA. Carolina} "Cherry-Laurel"). H. A splendid native broad-leaved evergreen shrub of comparatively slow growth but attaining largc size, with firm, dark green, glossy foliage. The small, fragrant flowers are in numerous close racemes and are followed by glossy, greenish black fruits. Fine for hedges and general planting. Nice stock in 3 -inch pots, 15 cts. each, $\$ 1.25$ for 10 ; larger, 25 cts. each, $\$ 2$ for 10 .

\section{LIGUSTRUM AMURENSE. Amoor River Privet.} sized shrub of bristling growth and small foliage that makes it especially valuable for sheared hedge-work, though we do not advise it for extreme South Florida. The small white flowers are borne in ercct, nany-flowered panicles. 1-yr., $15 \mathrm{cts}$. each, $\$ 1$ for $10, \$ 8$ per 100 .

L. LUCIDUM. Wax Privet. H. One of the handsomest of broad-leaved evergreens for Florida hedges. It makes a large-sized shrub with large, strong, dark glossy green leaves, and bears dense panicles of white flowers. In addition to being a valuable hedge plant, however, it is not only important for securing massed effects in the border, but for individual specimens, and the like, and as it is perfectly hardy cannot be recommended too highly for general planting throughout the state. From pots, $75 \mathrm{cts}$. each; from open ground, strong plants, $\$ 1.50$ each. We can also furnish an extra-fine line of heavy stock dug and balled from open ground-prices on application.

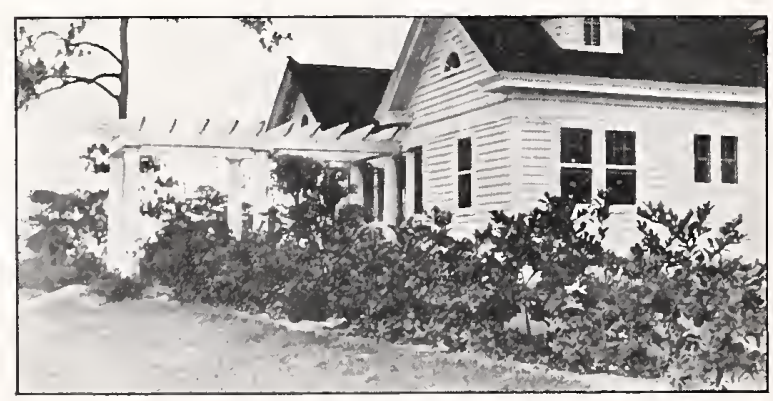

Cattley guava. Valuable hedge plant, doing well on thin sandy soil
L. NEPALENSE VARIEGATUM. Variegated Nepaul Privet. H. A splendid plant for hedge-work, borders, or single specimens but of somewhat more upright growth than the preceding and with smaller, thick, glossy foliage. While the leaves are variegated, this variegation is not objectionably prominent, and it might almost pass as a solid yellowish green. It does well on dry soils when once established. The bloom comes in spring and consists of large, dense panicles of white flowers. $50 \mathrm{cts}$. each, $\$ 4.50$ for 10 .

MICHELIA FUscata. Banana Shrub. H. China. A A fine large shrub of compact growth and ing 10 to 15 feet in height, perfectly hardy in the Middle and Lower South. The broad, dark green, glossy foliage is very ornamental, resembling that of a magnolia, only smaller. The flowers are an inch across, or larger, brownish yellow edged with light carmine, with an unusual banana-like fragrance, and coming from March to May. Makes a splendid sheared hedge of medium to rather large dimensions. A fine subject worthy of more extended planting. $\$ 1$ each, $\$ 9$ for 10 ; heavier, $\$ 2$ each, $\$ 18$ for 10 .

MYRICA CERIFERA. Wax Myrtle. H. Native. or small trees for hedge-work or general lawn planting. The foliage is a rich olive-green and the growth, when unrestrained, is vigorous and makes a great billowy mass. The berries, which make a marketable wax, are slate-colored and add a touch of grayish blue to the olive-green of the foliage, which is particularly charming. As a hedge it shears well and makes a dense, massive wall. The fact that it will do so well along the seashore of the coast, standing heavy salt wind and spray, is also greatly in its favor and should much increase its popularity. Strong plants, 25 cts. to $\$ 1$.

PITTOSPORUM TOBIRA. Tobira Shrub. H. Clina and Japan. Hardy,

woody shrub, especially valuable as a hedge subject, specimen plants of which attain 8 to 10 feet. The leaves are thick and leathery, dark, glossy green, forming lovely rosette-like growths, and the creamy flowers, fragrant but of small size, come in March. Especially valuable for seashore planting, withstanding strong salt winds exceedingly well. $50 \mathrm{cts}$. each, $\$ 4.50$ for 10 ; larger, $\$ 1$ each, $\$ 9$ for 10 ; extra heavy, $\$ 1.50$ each; fine specimens, $\$ 5$ each.

PSIDIUM CATTLEYANUM. Cattley Guava. ST. that its value as an ornamental has been generally overlooked. As a matter of fact, it is one of our most valuable subjects, especially for hedge- and border-work, and thrives in very dry situations. The foliage is most attractive and effective, being a rich, dark, glossy green which makes a most pleasing contrast with the light brown tint of the bark of the young wood. It stands shearing perfectly. In summer they are made more attractive by the Iarge, deep red fruits. See Fruit Department. Small, pot-grown plants, $15 \mathrm{cts}$. each, $\$ 1.25$ for 10 ; strong plants, 25 cts. each, $\$ 2$ for 10 ; heavier, $35 \mathrm{cts}$. each, $\$ 3$ for 10 ; extra heavy, $50 \mathrm{cts}$. each.

RAPHIOLEPIS INDICA. Indian Hawthorn. $H$. roundish, evergreen leaves and pinkish white flowers, sweetsccnted. This requires a soil of fairly heavy nature-it will not succeed on poor, thin lands. $50 \mathrm{cts}$. each, $\$ 4.50$ for 10 ; larger, $\$ 1$.

SEVERINIA BUXIFolia. H. Timor. A very E ERINIA handsome, dwarf shrub, related to the orange tribe, of great value for ornamental hedge-work in Florida. Quite hardy, standing as low a temperature as 20 degrees Fahr. without injury. Beautiful, dark green foliage of compact growth, with glossy black berries that add to the shrub's attractive appearance. Nice stock, 25 cts. each, $\$ 2$ for 10 ; stronger, 35 cts. each, $\$ 3$ for 10 ; extra strong, 50 cts. each.

TRIPHASIA TRIFOLIATA. Limeberry. T. China. RIPHASIA A valuable plant of low, horizontal, compact growth. One of the best subjects for smaller growing hedges in extreme South Florida and wcll-protected places. Leaves are small, dark green and trifoliate, the small flowers white and sweet-scented, and the reddish fruits are sweetish, sometimes used for preserving. 35 cts. each, $\$ 3$ for 10 . 


\section{ROYAL PALM NURSERIES}

\section{Group III. Mass Plantings}

There are a number of very sound reasons for the massing of plants; this practice is the outcome of generations of the best thought and not just a mere fancy or fad. The next time you are driving through the country, study a hammock growth or any other of nature's massed plantings; note the various textures of the different subjects which are emphasized when in close proximity. Note the difference in expression of the various groups, then go home and if you have been following the too frequent practice of scattered plantings, compare the effect you have with that secured by nature. Nine chances to one you'Il agree with the Iandscape man and readily catch his point of view. Remember there is as much real art in getting expression in foliage textures as with flowersprobably more so. But this is only one of the several reasons; you will acquire the others readily enough if you will apply a few minutes' study to the subject on your little trips around the country. Try it-you will be surprised at the real enjoyment and the deeper understanding of nature it will mean to you.

There are, roughly, three grades of mass planting-high, low, and intermediate-according to the habit of growth and amount of pruning done-high for background, low for foreground.

\section{(a) Low Mass Plantings}

ALLAMANDA NERIFOLIA. Bush Aliamanda. sized shrub with bricht $T$. This makes a low- to mediumyellow flowers about 2 inches across that are slightly darker than the more commonly known $A$. bendersonii and $A$. williamsii, and also less flaring and more tubular. Just the thing to plant back of Plumbago capensis. 25 cts. each, $\$ 2$ for 10 .

OTHER VARIETIES OF ALLAMANDAS, listed under vines, can also be used with splendid showy effect as low shrubs.

\section{DAEDALACANTHUS NERVOSUS. T. India.}

ing 2 to 4 feet high with large, coarse, dark green leaves and axilfary spikes of deep blue flowers, coning in winter. Strong plants, 35 cts. each, $\$ 3$ for 10 ; larger, 50 cts. each.

HYPERICUM AUREUM. H. A low shrub with masses of chaves, and masses of charming yellow flowers about an inch across. $25 \mathrm{cts}$. each, $\$ 2$ for 10; heavier, $50 \mathrm{cts}$. each.

JACOBINIA CoccineA. T. Brazil. An erect, ACOBINA shrubby herb growing about 4 feet high, with broad, elliptic, glossy green leaves and crimson flowers in terminal spikes, blooming constantly. Valuable as a border plant and for planting along streams and ponds and in moist woods. 25 cts. each, $\$ 2$ for 10 ; larger, $35 \mathrm{cts}$. each, $\$ 3$ for 10 .

JASMINUM primulinum. See page 22 for description.

J. PUBESCENS. See page 23 for description.

LONICER A NITIDA. H. An upright evergreen LONICERA honeysuckle, of small size, lately introduced. It has very small foliage and white flowers followed by purple berries. Fine for low hedges. $75 \mathrm{cts}$. each, $\$ 7$ for 10 .

LYCIUM CAROLINIANUM. H. Native. A small shrub, related to the cestrums, growing from

2 to 5 feet high, with fleshy leaves and small bluish flowers followed by a profusion of scarlet berries. Very valuable for seashore planting. Small plants, 25 cts. each, $\$ 2$ for 10 .

PLUMBAGO capensis. See page 23 for description.

RAPHIOLEPIS indica. See page 24 for description.

SEVERINIA buxifolia. See page 24 for description. STROBILANTHES (both species). See page 23 for
description.

TABERNAEMONTANA CASHMERE. T. TABERNAEMONTANA India. This is one of the best white flowering shrubs we know, growing about 3 to 5 feet high. The leaves are verv dark glossy green, wavy margined, and the flowers, borne in profusion periodically throughout the year, are single, white with yellow dot in center, and very attractive. 50 cts.

VIBURNUM suspensum. See page 23 for description.

VINCA ALBA. Periwinkle. T. A particularly valuable treme drought. Attractive green foliage and pure white flowers about 1 to $11 / 2$ inches across. Strong seedlings from open ground, easy to handle. $50 \mathrm{cts}$. for $10, \$ 3$ per 100 .

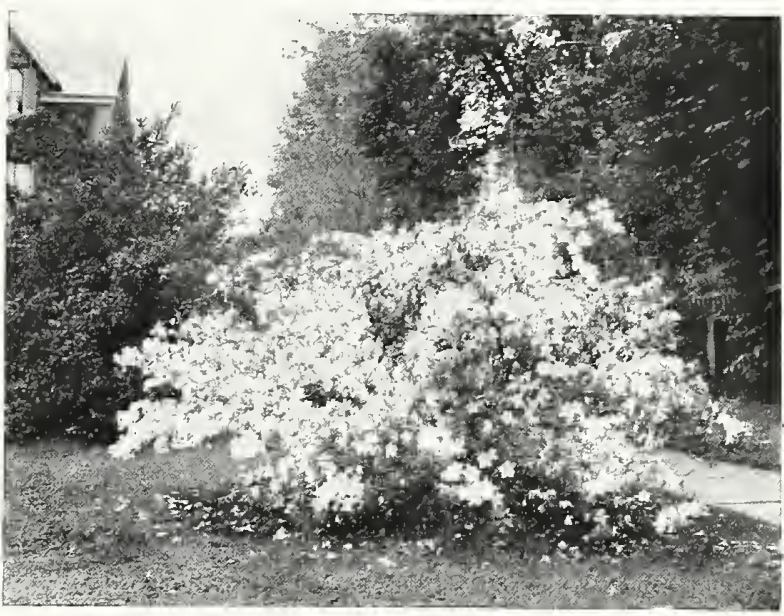

Azalea indica delights in a half-shady situation

\section{(b) Intermediate Mass Plantings}

ABELIA grandiflora. See page 22 for description.

ARTOBOTRYS O D OR A T Is SI M U S. False mine. T. Asia. A choice flowering shrub, semi-climbing in habit, valuable for planting against pergola columns and other support in extreme South Florida, with broad, glossy leaves and bearing yellow flowers with a delightful fragrance like that of ripe bananas and pineapples. The fruit is also highly fragrant but inedible. Fine plants, 50 cts. each, $\$ 4.50$ for 10 .

AZALEA INDICA. Indian or Chinese Azalea. H. If you happen to have a piece of hammock land on your property, especially one pitching off in a steep springy bank-and if you love flowers and brilliant colorings in great masses-then you are in luck! At strategic points along the path that winds through the woods, cut out areas of the underbrush and plant to Chinese Azaleas-the bigflowered ones that give great splashes of colorings to the winter and spring woodlands. You will be surprised to see dull, drab shadows spring into life and gaiety. Don't use any lime in planting-just plenty of well-rotted muck and manure, especially on the thinner, poorer soils. Of course, if you haven't such a woodland, do the next best thing - plant them on the shady side of your house or amongst the larger shrubs. While they rejoice in shady situations, they should not want for ample sunlight for best results, especially during the morning, and little extra attentions, such as fall applications of leaf-mold or something of the kind as a protecting mulch, will be well repaid by the added magnificence of the floral display in the spring. Our plants are all the large, singleflowered sorts, in white, pink, lavender, mauve, and shades of red, variegated, etc. Strong plants, $\$ 2$ to $\$ 3.50$. 


\section{PLANTS AND SHRUBS FOR MASSED PLANTINGS, continued}

BACCHARIS HALIMIFOLIA. Salt Bush. H good growth and habit which, during the late fall and early winter, is a cloudy mass of soft, downy white material used by nature for transporting seeds. Attains a height of 10 feet or more. Strong plants, $25 \mathrm{cts}$, each, $\$ 2$ for 10 ; heavier, $35 \mathrm{cts}$. each, $\$ 3$ for 10 ; very heavy, 50 cts. each, $\$ 4$ for 10 .

\section{BOUGAINVILLEAS IN VARIETY. While}

as vines, these wonderfully foriferous shades of purple to crimson-lake-red, can be handled as shrubs if properly trained. The common $B$. glabra sanderiana is particularly shrubby in its growth and is the best of the group for this purpose. When planted in conjunction with floriferous white-flowered subjects, such as white oleanders or Jasminum pubescens, it is marvelously effective. See Vines for descriptions and prices.

\section{CAESALPINIA PULChERRIMA. Dwarf Poin-}

T. Tropics. A superb shrub 6 to 10 feet high, with elegant pinnate foliage, surmounted during the greatest portion of the year by great terminal clusters of the most gorgeous red and yellow flowers. A very showy plant, suitable for conservatories, for bedding out in summer at the North, and for permanent shrubberies in Florida and the Tropics. Nicc young stock, 35 cts. each, $\$ 3$ for 10 .

\section{CALLISTEMON. Bottle Brush. These are partic- ularly interesting shrubs for}

South Florida planting, doing especially well on our highlands of the lake region without irrigation. The Catlistemons are all quite hardy, standing temperatures under 25 degrees Fahr. The quantity of blossom-spikes may be increased by judicious fall pruning and occasional applications of commercial fertilizers.

C. LANCEOLATUS. H. Australia. A splendid shrub of willowy growth, reaching a height of 6 to 12 feet, with long, narrow leaves and bright red flowers in thick spikes resembling bottle-brushes, whence the name is derived. These are very attractive and last some time in perfection. Strong plants, $\$ 1$ each, $\$ 9$ for 10

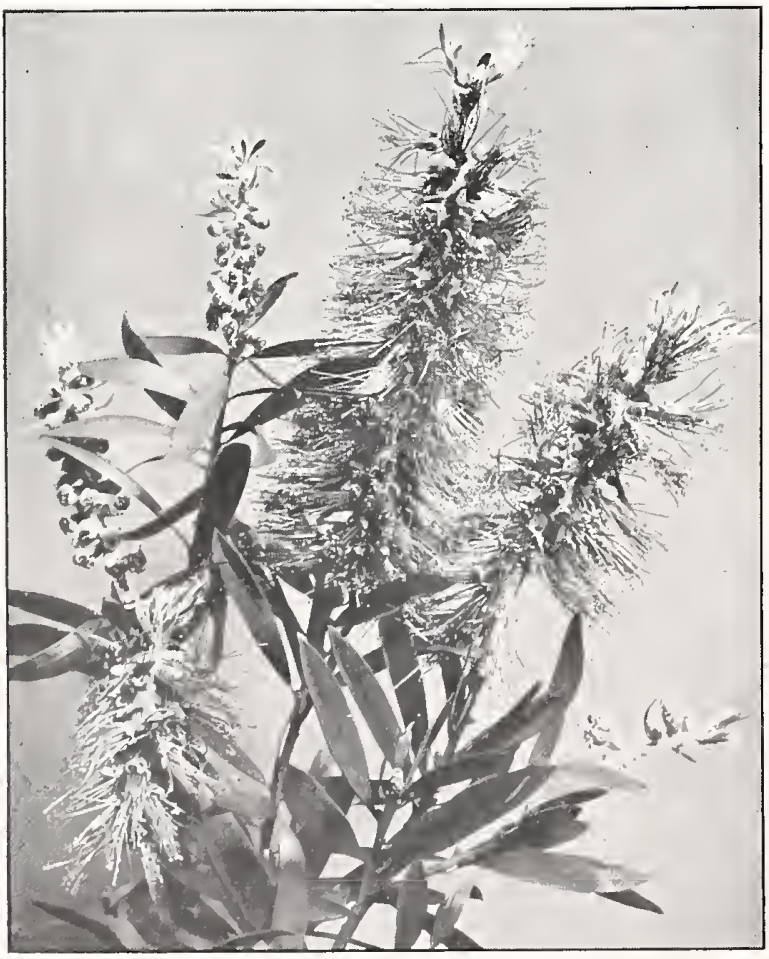

Callistemon. Bottle Brush Shrub
C. RIGIDUS. H. Australia. Stiflly branched shrub, lower and more stocky in habit than the preceding, with narrow leaves, 3 to 4 inches long, and dense spikes of large, deep red flowers. Fine plants, 35 cts. each, $\$ 3$ for 10 ; larger, $\$ 1$ each, $\$ 9$ for 10

CAMELLIA JAPONICA. Camellia (commonly eaves and large, showy, waxy flowers, suggesting the fullblown rose but more formal in design, ranging in colors from pure white through pinks to dark red. For most satisfactory results it should be planted in a partially shaded situation. Flowers in winter and early spring. Red, Pink, and Variegated, $\$ 2$ and $\$ 3$; Single Pink, \$1.

CATHA EDULIS. Khat. T. Arabia. The leaf of Yemen Arab that the poppy flower does for the Chinese and the coca plant for the South American. is a stimulant like alcohol without the latter's deleterious effects. It makes a sturdy plant 5 to 10 feet high, its appearance varying with the characteristics of the soil in which it is grown, with red stems and dark, glossy, evergreen foliage much resembling the camellia. Small plants, 50 cts.; larger, $\$ 1$.

CESTRUM. This represents one of the most attrac-

FI. tive groups of flowering shrubs for South o splendid advantage in landscape and general garden culture, not only because of the beautiful floral effect but because, to a large extent, they produce a wealth of bloom during the fal and winter months.

C. AURANTIACUM. T. Guatemala. A shrub with long, pendulous branches, soft oval leaves, and panicles of orangeyellow blossoms in profusion. $35 \mathrm{cts}$

C. DIURNuM. Day Jessamine. T. A large, quickgrowing shrub of upright habit, growing well in poorest soils and producing quantities of small, tubular white flowers at intervals throughout the year; valuable for cut-flower work. This subject is desirable for seashore planting, growing right along the shorc on the lower Florida Keys where it is subjected to severe salt spray. $35 \mathrm{cts}$.

C. ELEGANS. Red Coral Jessamine. T. Mexico. Tall, semi-climbing shrub, with a profusion of rose-pink and carmine flowers borne in loose, nodding clusters at the ends of the branches, blooming most of the year. $50 \mathrm{cts}$. each, $\$ 4.50$ for 10 .

C. NOCTURNUM. Night-blooming Jessamine. T. A large rank-rrowing shrub with flowers greenish in color, opening about sundown, and emitting a very heavy fragrance. This blooms at intervals throughout the year. 35 cts. each, $\$ 3$ for 10 ; larger, $50 \mathrm{cts}$. each.

CHALCAS paniculata. See page 22 for description.

CIEYERA JAPONICA. H. A smooth-leaved evergreen shrub of medium size, with fragrant, creamy white flowers. 50 cts.

CRYPTOSTEGIA MADAGASCARIENSIS. T. While properly a vine, this giving it a stake support from which it will hang as a dense mass. See Vine Department.

DURA NTA PLUMIERI. Golden Dewdrop. T. Amer-

tive shrubs of Florida gardens, of good size, reaching 10 to 15 feet, spreading, with graceful pendulous branches. Delicate lilac flowers borne in profusion in racemes toward the ends of the branches, blooming several times a year. The yellow fruits, like small pendant golden balls, also numerous, make a charming contrast with the flowers. This makes a very attractive foundation shrub when planted against a large building, as its small foliage and pendulous effect lend just the proper atmosphere for such location. 35 cts. each, $\$ 3$ for 10 ; larger, 50 cts. each.

EIAEAGNUS. Silver Thorn or Oleaster. H. Japan. is one of the most successful for Frorida cultivation, and we cannot rccommend it too highly for that purpose. For use in the shrubbery border, however, they need systematic pruning, especially when young. When so trained, they mature into splendid specimens of weeping habit. 


\section{ROYAL PALM NURSERIES}

ELÆAGNUS PUNGENS MACULATA. Golden Leaved Oleaster. H. A splendid evergreen shrub up to 6 feet high, with brown branches and bright green leaves beautifully blotched with golden yellow. The fruit is quite desirable, somewhat resembling cranberries, and ripcning in early spring. 50 cts.

E. REFLEXA. Climbing Elæagnus. H. A remarkably vigorous climbing form, making a scandent shrub, the younger twigs brown, the leaves grcen above and silvery beneath overspread with a bronze cast. If given support this will make a vigorous vine, though by pruning it makes a very desirable shrub. 35 and 50 cts.

E. SIMONII. Simon's Oleaster. H. Foliage elongated, silvery beneath; compact growth; edible fruit. $75 \mathrm{cts}$.

EUGENIA uniflora. See page 24 for description.

FORESTIERA porulosa. See page 22 for description.

HAMELIA ERECTA. Scarlet Bush. T. American Tropics. This is a beautiful shrub for

Florida planting, growing to 8 feet high, with attractive green foliage setting off the bright orange-scarlet flowers to advantage. In cool weather the foliage turns a rich bronze color or, in exposed situations, is shed entirely, to come out vigorously with the return of warmer weather. Not suited to exposed seashore planting. $35 \mathrm{cts}$. each, $\$ 3$ for 10 .

HIBISCUS ROSA-SINENSIS. Chinese Hibiscus. T. This is one of the most striking and satis-

factory shrubs for Florida planting, and with the new varieties we have originated it is now possible for gardens to have a wide range of pink, red and salmon shades. The plant is of quick growth and while subject to frost injury, being frozen down under ordinary conditions at about 28 degrees Fahr., still it has strong powers of recuperation and will come right up and bloom again within a few months as vigorously as ever. Not only is this subject adapted to single and group planting but does exceedingly well in hedge formation, standing clipping well, and, where properly cared for in respect to fertilizing, makes a continuous sheet of dark green foliage and large, bright flowers. By shearing they can be trained as standards, in the single specimens very satisfactorily.

We have introduced a number of new forms of cxquisite shades, some of which are noted in the following descriptions:

COLLERI. While not a strong grower, this variety produces double yellow blossoms of good form and splendid coloring. $\$ 1$.

DIANA. Large open blossom, 6 inches across, with reflexed crepe-like petals. Color rich glowing orange-red relieved by light pink veins radiating from crimson center; reverse of petals lighter, combining yellow as well as pink tones with the orange. Altogether, a rare and beautiful sort. $\$ 1$.

DOUBLE PINK. A very rich carmine-pink flower of lovely appearance, resembling a fine peony, but do not confuse with the light pink Peachblow. 35 and $50 \mathrm{cts}$. each; heavy, field-grown stock, $\$ 1$ each, $\$ 9$ for 10.

DOUBLE SCARLET. A deep scarlet-colored flower of most attractive appearance. The plant is not so rapid in growth as the single-flowered varieties, but is free blooming. 35 and $50 \mathrm{cts}$. each; heavy, freld-grown stock, $\$ 1$ each, $\$ 9$ for 10.

EUTERPE. A large, single flower, the broad petals yellow with small reddish veins, shading through a delicate violet into the intense red center. Yellow beneath with prominent veins, shading into white toward the calyx. Leaves delicately veined and rather small. General effect of flower is salmon; profuse bloomer. Strong stock, $25 \mathrm{cts}$. each, $\$ 2$ for 10 ; extralarge, $35 \mathrm{cts}$. each, $\$ 3$ for 10 ; heavier, $50 \mathrm{cts}$. each; heavy, freldgrown stock, $\$ 1$ each, $\$ 9$ for 10

PEACHBLOW. A very beautiful double flower of a pale pink color, with dark center. Do not confuse the dark carminepink variety, Double Pink, with this. $35 \mathrm{cts}$. each, $\$ 3$ for 10 ; heavier, 50 cts, each; heavy, ficld-grown, stock, $\$ 1$ each, $\$ 9$ for 10 .

PSYCHE. Dainty, rich scarlet-red blossom, very small, open form, petals curved upward and outward, with edges dceply cut and the entire surfaces of a crepe-like texture. $50 \mathrm{cts}$.

SCHIZOPETALUS. A small single flower with peculiarly cut and twisted petals, pinkish red in general color. Flowers droop over gracefully, like a fuchsia. $50 \mathrm{cts}$.

SINGLE PINK VERSICOLOR. Same form as Versicolor except it is rich pink in color instead of scarlet. $35 \mathrm{cts}$. each, $\$ 3$ for 10; heavy, field-grown stock, $\$ 1$ each, $\$ 9$ for 10 .

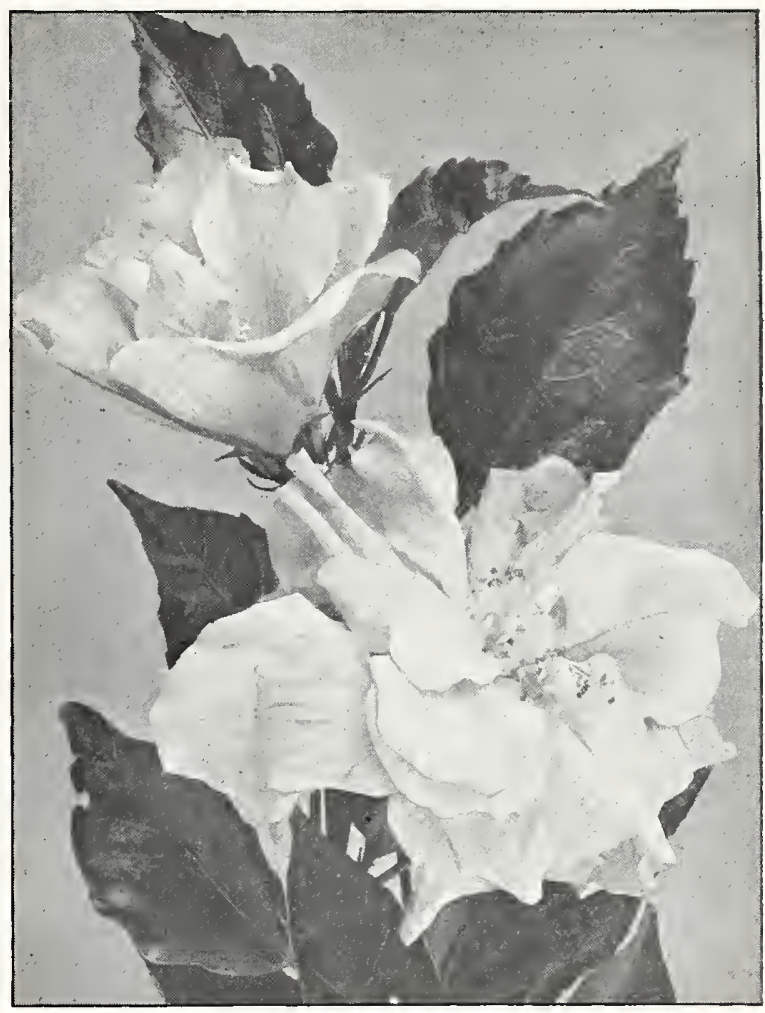

Chinese Hibiscus, Peachblow

SINGLE SCARLET. The most gorgeous sort we grow, with flaming flowers at all seasons. The best sort for hedge work, especially if it is to be sheared. Strong stock, $25 \mathrm{cts}$. each, $\$ 2$ for 10 ; extra heavy, 35 cts. each, $\$ 3$ for 10 ; heavier, limited number at $50 \mathrm{cts}$. each; heavy, freld-grown stock, $\$ 1$ each, $\$ 9$ for 10 .

TERPSICHORE. Medium-sized, single flower, with crepelike light pink petals having numerous darker pink veins, all shading to the dark red center. 35 cts. each, $\$ 3$ for 10 ; heavier, $50 \mathrm{cts}$. each.

THALIA. A single flower with silky, crepe-like pink petals and burnt sienna center; light pink and cream on reverse side. Vcry dainty. 35 cts. each, $\$ 3$ for 10 ; heavy, field-grown stock, $\$ 1$ each, $\$ 9$ for 10 .

URANIA. Large, single flower; petals light salmon, with faint pink nerves and lovely light pink center; lighter beneath and nerves prominent. Las a crepe-like effect $35 \mathrm{cts}$, each, $\$ 3$ for 10; heavier, $50 \mathrm{cts}$. each; strong, field-grown stock, $\$ 1$ each, \$9 for 10 .

VERSICOLOR. Single, light carmine-scarlet flowers, shaded straw-color and deep red in center. Strong stock, $35 \mathrm{cts}$. each, $\$ 3$ for 10 ; heavier, $50 \mathrm{cts}$. each.

HYDRANGEA HORTENSIS. French Hydrangeas. H. A deciduous shrub

with large, coarse leaves and round heads of flowers in exquisite shades. Although frequently used for foundation plantings, it is not adapted to this use, being deciduous, with a long dormant period. Color of the pink and blue sorts is variable according to the acidity of the soil; for blue the soil should be acid, with plenty of humus and organic manures; for pink color use lime and chemical fertilizers, no humus.
AVALANCHE. White. E. G. HILL. Bright pink.

BOU QUeT ROSE. Pink. MOUSSEline. Blue. Price of all sorts, $50 \mathrm{cts}$. each, $\$ 4.50$ for 10

JASMINUM FLORIDUM. H. A new variety of ASMINUM the hardy type, resembling $J$. primulinum in foliage but of more vigorous, upright growth. Very promising. $50 \mathrm{cts}$. 
PLANTS AND SHRUBS FOR MASSED PLANTINGS, continued

LANTANA. Tropical America. A genus of very gorto perfection in Florida, on almost any kind of soil. If frozen back they come up from the roots letter than ever and are soon in flower. We have several choice varieties, all 25 cts. cach, $\$ 2$ for 10 .

PINK AND YELLOW.

WHITE.

YELLOW AND ORANGE. YELLOW.

GRAND SULTAN. Red.

LAUROCERASUS caroliniana. See page 24 for description. LAWSONIA. See page 23 for description.

LEONOTIS LEONURUS. Lion's Tail. T. South Africa. A quick-growing, rather tender shrubby plant, growing 3 to 6 feet high, with hairy stems, soft foliage and queer, heavy tufted spikes of orange-yellow flowers. 25 and 50 cts.

LEPTOSPERMUM SCOPARIUM. H. A shrub dark green foliage. A profuse bloomer, with flowers carminered. $50 \mathrm{cts}$.

LIGUSTRUM. See page 24 for description.

MALVAVISCUS ARBoreUS. Turk's Cap. T. to hibiscus, of vigorous growth with light green leaves of large size. The scarlet flowers hang pendant, never fully opening, and, while especially floriferous in the winter, it is in more or less constant bloom throughout the year. $35 \mathrm{cts}$. each, $\$ 3$ for 10 ; heavier, $50 \mathrm{cts}$. each, $\$ 4$ for 10 ; extra heavy, $\$ 1$ each, \$9 for 10 .

MELIA FLORIBUNDA. Indian Lilac. T. An attractive dwarf form of the China Tree or Pride of India, with evergreen, pinnate leaves and light purplish
flowers throughout a long season. Rarely reaches a height of 5 feet. 75 cts. each, $\$ 6.50$ for 10 .

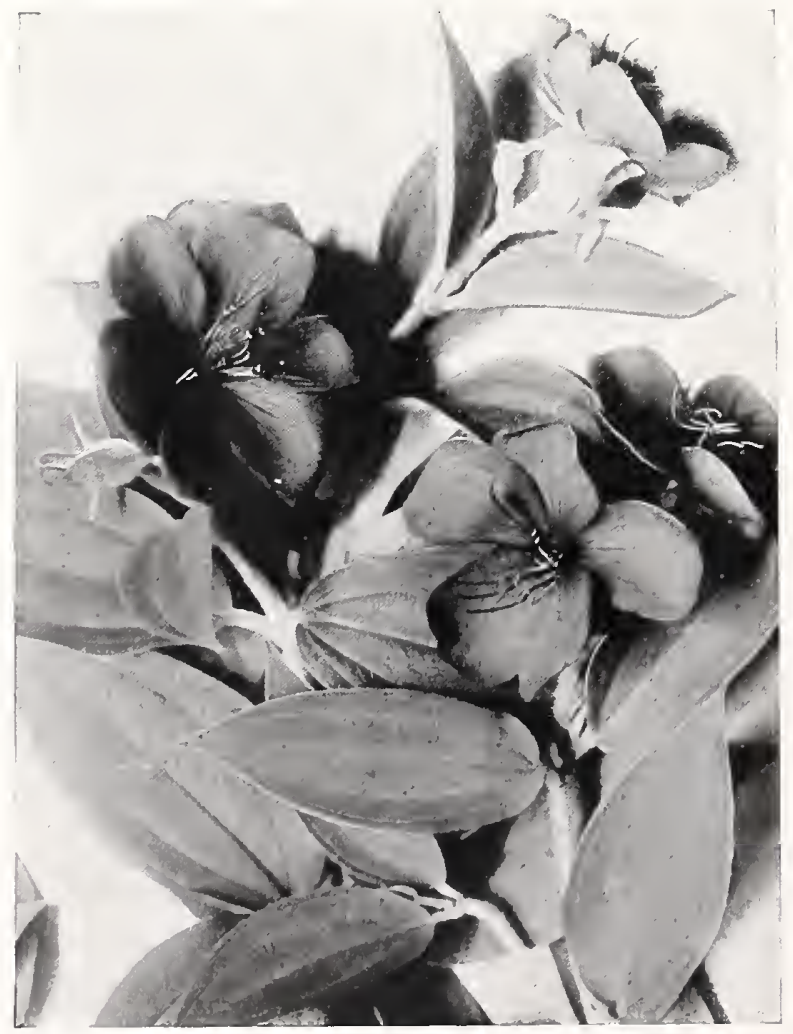

The royal purple Tibouchina semidecandra
MYRTUS Communis. Sweet Myrtle. H. South IRTUS Europe. An erect shrub with fine foliage, very fragrant, and white flowers about an inch across. A splendid shrub for Florida, but should be in a sunny location. 35 and 75 cts.

PITTOSPORUM Tobira. See page 24 for description.

PHYLLANTHUS nivosus purpureus. See page 23 for description.

PSIDIUM cattleyanum. See page 24 for description.

Other Varieties of Guavas. See Fruit Department.

PUNICA GRANATUM. Pomegranate: H. A largeUICA sized fruit with thin, tough rind. The flesh is a beautiful wine-color, crisp, sweet, and of exquisite flavor. Very attractive as a shrub, with flowers of reddish orange effect. Strong plants, 50 cts. each, $\$ 4.50$ for 10 . See, also, Fruit Department.

RHODOMYRTUS tomentosus. See page 23 for description.

RUSSELLIA JUNCEA. Coral Plant or Fountain SSLLIA Plant. T. Central America. A very attractive variation from the more common types of shrubs, to which it makes a pleasing contrast, with its wiry, rushlike pendulous branches and tiny green leaves. The plant is almost continuously in bloom with quantities of small, tubular coral-red flowers. 35 and 50 cts.

TABERNAEMONTANA coronaria, mine or Rose Bay. T. India. A beautiful shrub, growing to 8 feet high, with dark, glossy green foliage, and large, pure white, double night-scented flowers produced at intervals through the year. Makes a splendid ornamental hedge, not defensive. $35 \mathrm{cts}$. each, $\$ 3$ for 10; heavier, $50 \mathrm{cts}$. each, $\$ 4.50$ for 10 ; extra heavy, 75 cts. each.

T. GRANDIFOLIA. Large-leaved Rose Bay. T. Tropics. A magnificent shrub, much larger and more vigorous than the former, though not quite so floriferous, with very handsome, large glossy leaves of a beautiful shade of green. One of the best subjects we know for massing and as an intermediate background. Flowers of good size and substance, double, pure white. 35 and $50 \mathrm{cts}$.

'TECOMA CAPENSIS. T. This is a true vine, yet by heading back from year to year it makes a

valuable scarlet-orange-flowered shrub of handsome pinnate foliage. See Vines.

TETRAPANAX PAPYRIFERA. Rice Paper leaves are palmate, silvery on under side and exceedingly andsome. The plant grows upright like a palm, seldom branching, to a height of 8 to 12 feet, and in early winter throws out feathery spikes of bloom several feet in length. $35 \mathrm{cts}$. each, $\$ 3$ for 10 .

THEA sinensis. Tea Plant. H. While this is best HEA known as furnishing the tea leaves of commerce, it is a valuable hardy shrub of medium-sized, coarse foliage and compact, bushy growth, with white flowers an inch across. $\$ 1$ and $\$ 2$

THEVETIA NERIFOLIA. Trumpet Flower. $\mathbf{T}$. known as "Lucky Seeds" and the fruits as "Tiger Apples.") An attractive shrub reaching 6 to 10 feet, with narrow, shining leaves 4 to 6 inches long, and bell-shaped, yellow flowers 3 inches long. This will stand some frost. 50 cts.

THUNBERGIA erecta and erecta alba. See page 23 for description.

THUYA ORIENTALIS COMPACTA. Compact Arborvitæ. H. A coniferous evergreen, conical in form, exceedingly dense and regular in growth, with flat folian more or less strongly scented, and dark green in color. We do not recommend these for South Florida planting where there are so many splendid broad-leaved evergreen shrubs for securing tropical effects rather than the cold severity of this typically northern subject. $35 \mathrm{cts}$. each, $\$ 3$ for 10 .

T., ROSEDALE HYBRID. A very unique and handsome dwarf species of Arborvita, with dark blue-green foliage, sometimes of a bronze cast. Of dense habit and conical shape. 35 cts. each, $\$ 3$ for 10. 


\section{ROYAL PALM NURSERIES}

TIBOUCHINA SEMIDECANDRA. T. Brazil.

liest flowered shrubs for the the a doubt one of the loverather straggling habit, it can be kept in good shape by pruning. It grows from 6 to 10 feet high, and has soft velvety foliage of rich color, turning bronze before dropping. But it is the flower that is the "crowning beauty"-a wonderful, rich, royal purple flower, the most striking purple we know, and nearly 3 inches across. $50 \mathrm{cts}$. each, $\$ 4.50$ for 10 .

VACCINIUM VIRGATUM. Orchard Blueberry. makes a handsome shrub of spreading habit, with small foliage and blue-black berries of delicious quality. It should be grown only on moderately moist soil, slightly acid. See Fruit Department.

VIBURNUM ODORATISSIMUM. H. China I An evergreen shrub of great merit all over the Lower South, doing well even in South Florida, and attaining a height of 6 to 10 feet. The leaves are large and glossy green, of good color and substance, and the fragrant flowers come in late spring. We urge the use of this with others of its type for getting a permanent border planting of good texture, such as pittosporums, Ligustrum lucidum and L. nepalense, and the like. $75 \mathrm{cts}$. each, $\$ 7$ for 10 .

WARNERIA AUGUSTA. (Gardenia florida.) GarARIERIA denia or Cape Jasmine. H. China. A splendid broad-leaved evergreen shrub, 6 to 8 feet high, with very dark green, glossy foliage and magnificent waxy white flowers of good size and exceedingly fragrant. Strong plants, 50 cts. each, $\$ 4.50$ for 10 ; heavy, two-year plants, 75 cts. each, $\$ 7$ for 10 .

\section{(c) Larger Mass Plantings}

This, like all other classifications, is suggestive rather than intended as complete. As in the foregoing two groups, all these subjects are susceptible to special treatment, as pruning, which might place them in the medium, or even small-sized group-this final decision must rest with the planter. We merely make this suggestion as a help to those not ordinarily familiar with the subjects.

ACACIA FARnesiana. Popinac. H. Tropics and ACACIA subtropics. A much-branched shrub some 10 to 20 feet high, of open structure, with very fine pinnate foliage, giving a thin, airy effect. Does exceedingly well close to salt water and because of its character is excellent for lending an effect of distance. 35 cts. each, $\$ 3$ for 10.
ACALYPHA HISPIDA. Chenille Plant. T. A age and bright red flriking subject with broad "cheen foll, about 2 feet long, pendant from the axils of the leaves. Fastgrowing plant, attaining 10 feet in height; blooms throughout the year, beginning when very small, even as a pot subject. 35c.

\section{ASSONIA PUNCTATA. T. An open, somewhat strag-} gling grower, with large, coarse leaves. The umbels, or flower-heads, consist of fewer flowers than $A$ Wallicbii but larger and of a deeper shade of pink, coming in December and January. A splendid shrub for big, open borders in Florida and the Tropics, attaining a height of 8 to 10 feet. 75 cts.

A. WALLICHII. T. Madagascar. This makes a large shrub or small tree up to 30 feet high, with large, velvety cordate leaves and lovely pink flowers in large, compact, drooping "heads" in winter. A very showy plant when in bloom. An especially fine subject for the big open border where it can have plenty of room to develop. $75 \mathrm{cts}$. each, $\$ 6.50$ for 10 .

CARYOPHYLLUS jambos. See Trees, page 15.

CESTRUM diurnum. Day Jessamine. T. See page 26.

COCCOLOBIS uvifera. See Trees, page 15.

\section{COFFE A ARABICA. Arabian or Commercial Coffee.} T. A splendid decorative plant and valuable ornamental shrub for extreme South Florida and the Tropics. The broad, evergreen, dark glossy green leaves resemble chestnut foliage and the shrubs, or small trees, are a profusion of elegant white blossoms in the spring. Later the coffee berries turn bright scarlet as they ripen, making a striking and beautiful picture. We have several of the best commercial strains in stock in the following kinds and prices: Murta, Erecta, and Padang, 50 cts.; Erecta and Maragogipe, 75 cts.

DATURA ARBOREA. Angel's Trumpet. T. Peru A TURA and Chile. A large shrub, treelike in grant white flowers are long, trumpet-shaped and open in the evening. Strong plants, 25 cts. each, $\$ 2$ for 10.

EUGENIA hookeriana. See page 24.

\section{LAGERSTROEMIA FLOS-REGINÆ. Queen}

This is, without a doubt, one of the most magnificent of our introductions. It is a tree reaching 50 to 60 feet in height, with magnificent foliage and gigantic panicles of mauve flowers, nodding on the ends of the strong, graceful shoots; usually seen as a shrub blooming when small. The petals of the large individual flowers are of the crepe-like texture of the common, hardier type of Crape Myrtle, only much larger. $35 \mathrm{cts}$. each, $\$ 3$ for $10 ; 50$ cts. each, $\$ 4.50$ for 10 .

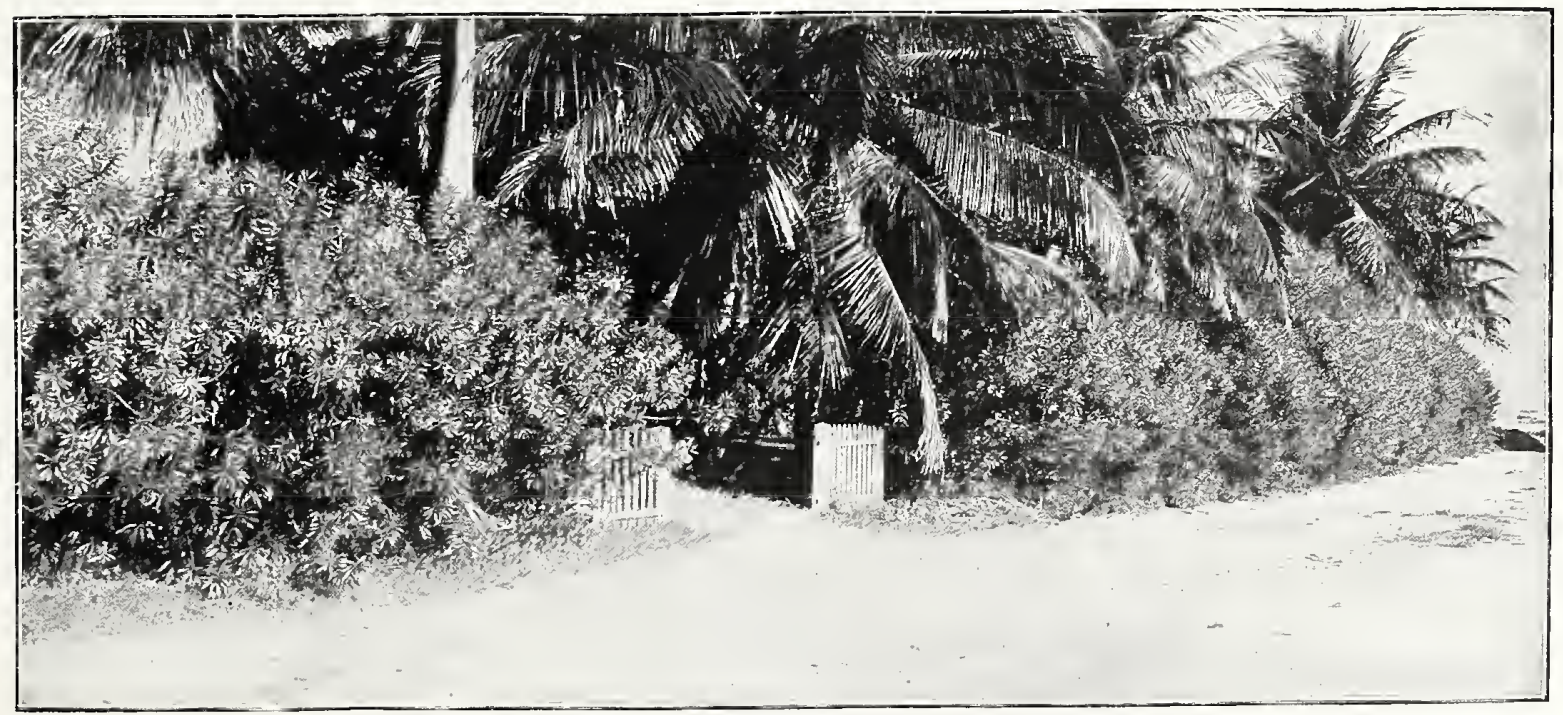

A border of Oleanders and Coconut PaIms 


\section{PLANTS AND SHRUBS FOR MASSED PLANTINGS, continued}

LAGERSTREMIA INDICA. Crape Myrtle. H. China and India. Too much cannot be said in praise of this beautiful deciduous Indian shrub. The masses of flowers are profusely borne from spring until autumn, on small as well as large plants. A splendid plant for bedding out, even in the North where it gives perfect satisfaction. Grand for hedges, single specimens, or masses in general southern planting.

One-year plants, $25 \mathrm{cts}$. each, $\$ 2$ for $10, \$ 18$ per $100 ; 3$ to $4 \mathrm{ft}$. $50 \mathrm{cts}$. each, $\$ 4$ for $10, \$ 30$ per $100 ; 5$ to $7 \mathrm{ft}$., $\$ 1$ each, $\$ 9$ for 10 , $\$ 75$ per 100 .

Carmine. Sometimes catalogued as "Crimson." An exceedingly bright-colored flower. This variety was propagated from the choicest plant out of a large lot of Indian seedlings of our importation dating from 1886. The general favorite.

Pink. The old-fashioned sort so generally grown around outhern homesteads.

Purple. A light purple flower, varying in shade with soil conditions. Blooms best in July and August.

White. (In small supply.) $50 \mathrm{cts}$.

MELALEUCA ERICIFolia. T. Australia A with slender branches and delicate foliage, the leaves suggesting heather. Flowers are yellowish white. $50 \mathrm{cts}$. each, $\$ 4.50$ for 10 .

MELASTOMA MOLKENBOERII. T. Java. A at tractive, deeply veined leaves and beautiful mauve flowers. Very ornamental and adapted to extreme South Florida planting generally, but not doing well on high, dry, thirsty soil. Blooms when very small. $50 \mathrm{cts}$. each, $\$ 4.50$ for 10 .

MICHELIA fuscata. See page 24.

MYRICA cerifera. See page 24.

NERIUM OLEANDER. Oleander. H. So many people, we have found, objected to this subject

because they have only been accustomed to seeing great, scraggly, big-caned, ugly specimens in deserted hedge-rows or odd corners, the miserable victims of unpardonable neglect. As a matter of fact, this is one of the very loveliest of all flowering shrubs for general Florida planting and along the Gulf Coast generally, and the fact that it will grow in almost any soil and under almost any condition in the state makes it more than doubly valuable. It is true that it will not be uninjured by cold in the more northerly sections, in severe freezes, but there is considerable difference in the relative hardiness of the different sorts and, even when killed down occasionally, it comes right back under good culture and flowers freely as before. The following varieties are more hardy than the others: Carneum, Frederick Guibert, Dr. Golfin, Savort, Single White, De Brun.

While not suited for sheared hedge-work, they make splendid informal hedges - a double hedge of white Olcander background with single scarlet hibiscus foreground, or Carneum Oleander with pink Hibiscus foreground, and the like, make wonderfully effective enclosures for formal gardens, as screcns for fences, and many other useful purposes. The flowers come in a wide range of color and in great profusion during the spring months, and some sorts bloom more or less throughout the summer. All shades make a splendid effect with the greygreen foliage which, even when there is no bloom, is attractive on properly kept specimens. The great trouble in the case of the Gleander-and indeed with most of our tropical shrubbery -is that the owner does not use the pruning shears! People who in the North would not think of neglecting their shrubs seem to take it for granted that under tropical conditions plants should grow and thrive and look well all the year round and under all conditions without any care. As a matter of fact they should receive as much attention here as elsewhere and under some conditions even more.

In the North the Oleander used to be widely grown as a tub plant; for Iong it was neglected, but again there is a revived interest being shown in the plant for this purpose and this should increase as the range of desirable colorings develops. Oleanders can be handled at any time of the year, though for the colder sections of the state we recommend spring planting, as with most tropical shrubs that are affected by low temperatures.
ATROPURPUREUM PLENUM. Double purplish crimson flower, with occasional narrow white stripes. The deepest red of any sort. $50 \mathrm{cts}$. each, $\$ 4.50$ for 10 ; larger, $\$ 1$ each, $\$ 9$ for 10 .

ATROPURPUREUM. The single form of the foregoing. $50 \mathrm{cts}$. each, $\$ 4$ for 10 ; larger, $\$ 1$ each.

CARNEUM. Single, flesh-colored flower with pink lines in throat; very floriferous. $35 \mathrm{cts}$. each, $\$ 3$ for 10 .

DE BRUN. Double; deep crimson, slightly lighter in color and larger in size than Atropurpureum. 50 cts. each, $\$ 4.50$ for 10 .

DR. GOLFIN. Magnificent single flower; bright deep pink (almost red); scented; opens early in the season. $75 \mathrm{cts}$, each, $\$ 7$ for 10 ; larger, $\$ 1.25$ each, $\$ 12$ for 10 .

FREDERICK GUIBERT. Single; light pink with crimson throat. 35 and $50 \mathrm{cts}$.

M ME. PLANCHON. Double; rosy lilac in color. $50 \mathrm{cts}$. MME. SAHUT. Semi-double; pale rose, striped white. 50 cts. each, $\$ 4.50$ for 10 ; larger, $\$ 1$ each.

MADONNA GRANDIFLORA. Pure white, double, of large ize, very fragrant. The best of the doublc whites. $50 \mathrm{cts}$.

MRS. F. ROEDING. One of the very finest sorts, having heavy clusters of large, double, salmon-pink blossons, freely produced. $\$ 1$ and $\$ 1.50$.

SAVORT. Small, double, pale pink flower, very fine and floriferous. A strong, upright grower, hardy and desirable. $50 \mathrm{cts}$. and $\$ 1$.

SINGLE CREAM. Flowers rather small in size, but profuse. $35 \mathrm{cts}$. each, $\$ 3$ for 10 ; Iarger, $50 \mathrm{cts}$. and $\$ 1$.

SINGLE PINK. Shell-pink, scented flowers, borne in very large trusses. A grand variety. 35 c. each, $\$ 3$ for 10 ; larger, $50 \mathrm{c}$.

SINGLE WHITE. A very hardy sort; profuse bloomer, and altogether fine. The old reliable white variety. $50 \mathrm{cts}$.

SPLENDENS. The old-fashioned, double, rosy pink variety. Splendid large flowers in heavy trusses; sweet-scented. $35 \mathrm{cts}$. each, $\$ 3$ for 10 ; larger, $50 \mathrm{cts}$.

OXYANTHUS Isthmia. T. Probably South and most at tractive large shrubs we know for South Florida. with its broad, dark glossy evergreen foliage, erect habit, and shapely white blossoms of most unusual shape-long tubular, only an eighth of an inch through yet 6 inches long, flaring out suddenly to an inch across, and of odor most attractive and intense. New and rare, flowering several times yearly. $\$ 1$.

SCHINUS TERebinthifolius. Brazilian Pepper. ST. This is not the pepper tree of Cali-

fornia, making a large, scrambling shrub rather than a tree. Under proper treatment, especially in respect to pruning, it makes a strikingly attractive subject, with its coarsely compound leaves of dark green and great masses of scarlet berries in winter and spring. It is especially valuable as a large shrub in big, open borders and grows well under most average conditions. It will not thrive if exposed to salt spray and strong winds along the seashore. $25 \mathrm{cts}$. each, $\$ 2$ for 10; heavier, $50 \mathrm{cts}$. each, $\$ 4.50$ for 10 .

SESBA NIA PUNICEA. H. A leguminous shrub, deSiduous, allied to cresalpinia, of very quick growt h. Leaves compound; flowers brilliant orange-scarlet, freely borne during most of the warmer weather in attractive, drooping racemes. Bccause of its deciduous habit, being bare and unsightly during the colder months, we recommend using it rather back in large borders where its brilliant coloring will nake a better show because of the situation and during the winter its unat ractive appearance will not be so conspicuous. 25 cts. each, \$2 for 10.

STENOLOBIUM STANS. Yellow Elder. T. A Iargc size with compound leaves and terminal clusters of intensely fragrant, golden ycllow flowers blooming in the autumn. $35 \mathrm{cts}$. cach, $\$ 3$ for 10

S. STANS SAMBUCIFOLIA. T. Similar to the preceding except in its habit of blooming in the spring as well as in the autumn, making it valuablc for our winter residents' grounds. 35 cts. each, $\$ 3$ for 10 .

When you plant, don't forget the birds! Remember they like the fruits of Carissa, Caryophyllus, Cestrum nocturnum, Coccolobis, Duranta, Eriobotrya, Eugenia uniflora, Ixora, Lantanas, Morus, Myrica, Phœenix in variety, Psidium, Raphiolepis, Solanum seaforthianum, Thrinax in variety. 


\section{ROYAL PALM NURSERIES}

\section{Group IV. Variegated-leaved Shrubs}

As a rule $w \mathrm{c}$ do not use much if any variegated foliage in mass plantings, unless something like Ligustrum nepalense variegatum which is so obscurely variegated as not to be conspicuously obtrusive. Strongly variegated plants are not, as a rule, natural in the sense of normal-they must be considered more or less in the light of curiosities and as such should be used with great care. They can be used at times to telling effect, but we certainly suggest the exercise of great caution, as many a fairly good planting has bcen spoiled with them-there is such a tcmptation to use them in tropical planting because of the "noise" they create. It should be remembered that good taste is better expressed in more quiet tones of greens, relying more on the flowers for the color relief. If you wish, use variegated foliage, but exercise care and discrimination.

ACALYPHA GoDsefFraNA. T. A dwarf-growing bright green leaves margined yellow and more or less suffused with pink. An attractive subject of special value for mixing with fern borders witb discretion, in patio plantings, and at other points. 35 cts.

A. MARGINATA. T. The Iargest sort in the genus, growing in open ground up to 8 feet high; fast growing. Leaves green, margined with varying shades of red, pink, and cream. In cool weather is exceptionally gorgeous. $25 \mathrm{cts}$. each, $\$ 2$ for 10 ; larger, $35 \mathrm{cts}$. each, $\$ 3$ for 10 ; extra Iarge, $\$ 1$ each.

A. MOSAICA. T. Mosaic-leaved. A most gorgeous plant, with curiously marked foliage showing all shades of green, yellow, and red. Very attractive planted among green-foliaged plants. A fine plant 4 to 6 feet high. 25 cts. each, \$2 for 10 ; larger, 35 cts. each, $\$ 3$ for 10 ; extra large, $\$ 1$ each.

A. TRICOLOR. T. Resembling the preceding, but with regular foliage, mostly of a rich red effect. A grand plant 6 to 8 feet high. 35 cts. each, $\$ 3$ for 10 . ARALIA BALFOURI. A new species, 3 to 4 feet gated green, white, and cream, making a shrubby plant up to 10 feet in height. $35 \mathrm{cts}$. each, $\$ 3$ for 10 .

PHYLLANTHUS N NUS. S S O R OSEO - PICShrub with loose, rather wiry branches, somewhat zigzag. Leaves compound, mottled with white and pink. A charming plant for low hedges or borders, especially in quite dark surroundings where it serves to brighten up wonderfully. 25 and 35 cts.

\section{PHYLLAUREA VARIEGATA. Crotons. T.}

variegated foliage, both narrow and broad, requiring plenty of heat and moisture Now and broad, requiring plants can furnish such a variety of color. In very formal plantings where it is desired to have formal masses of bedding plants but of more permanent character, nothing serves better to give a delirious riot of color than Crotons. They grow well in tubs and can be used in hotel lobbies and similar places to give a bright, tropical effect to good advantage, requiring only normal care for good results. Mixed plants, not labeled, small, and different, 25 cts. each, \$2 for 10; better,

35 cts. each, $\$ 3$ for 10 ; larger, 50 cts. each, $\$ 4.50$ for 10

Following is a list of the choicer varieties and in addition we have a number of sorts in a great variety of form and color not sufficientIy distinctive to merit special descriptions. These we are selling in mixed collections, as noted heretofore, and can be supplied according to special preferences as wide- or narrow-leaved, lighter green and yellow tones or darker green and red tones predominating, and the like.

Amabile. Broad-leaved, of slow growth, very highly colored, showing pink, purple, green, and yellow. $35 \mathrm{cts}$.

Andreanum. Broad-leaved; exceedingly rich yellow leaves. "Canned sunshine," someone said of it. 35 cts.

Aureo-maculatum. Very small and narrow foliage; green, spotted yeilow. 35 and $50 \mathrm{cts}$.

General Paget. Leaves extremely broad, green and yellow; a superb show variety. $50 \mathrm{cts}$.
Nestor. Bright green leaves with a broad band of yellow down midrib and with yellow spots. 35 and 50 cts.

No. 5. Very long leaves, yellow and green, blotched red. 35 and 50 cts.

Orvilla. Beautiful broad leaves, green, barred and spotted with deep yellow. Splendid. 35 and 50 cts.

Picturatum. Narrow, long leaves, green, carmine, yellow, orange, etc. Very rich colored. 35 cts., 50 cts., and $\$ 1$.

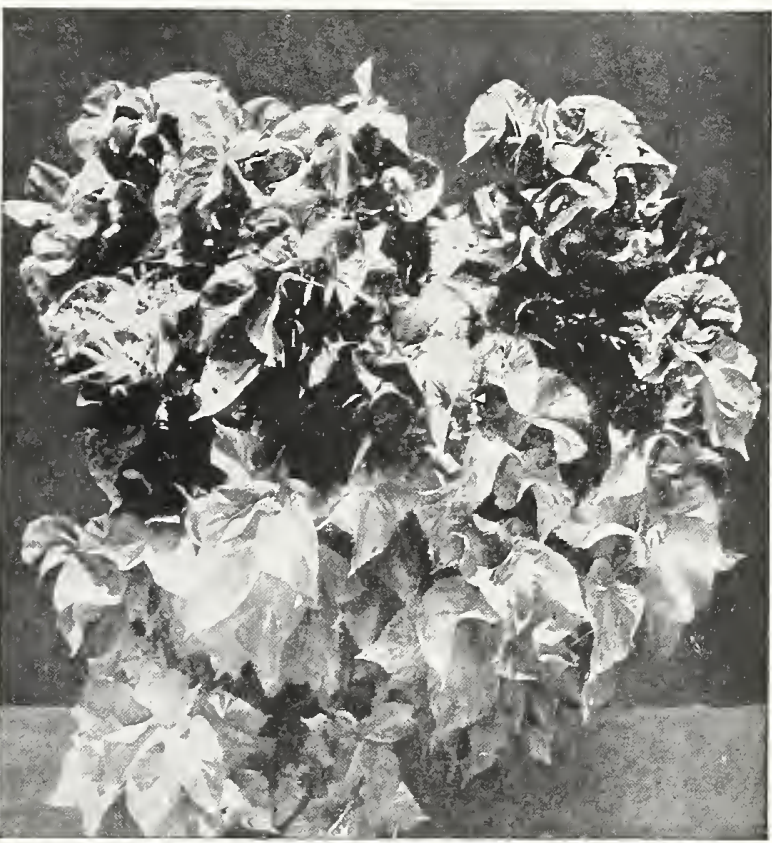

Acalypha mosaica

Robert Craig. Glowing orange-red to dark red and green. $50 \mathrm{cts}$.

Superbus. Very narrow foliage with wavy edges; yellow, margined green. 35 cts.

Veitchii. Broad-leaved, green, pink, and crimson. 35 and $50 \mathrm{cts}$.

Weismanni. Leaves rather narrow; green barred and blotched yellow, with pink or red stems. 35 and $50 \mathrm{cts}$.

\section{PITTOSPORUM TOBIRA VARIEGATUM. H.} page 24) but not so strong a grower, being more dwarf, with lighter green foliage variegated with creamy white. Valuable in certain situations to touch up a dark place or bring out a dark planting. $50 \mathrm{cts}$. each, $\$ 4.50$ for 10 ; Iarger $\$ 1$ and $\$ 1.50$.

Do you realize what charm there is about a garden pool-how simple of construction and relatively inexpensive it is? Probably no other element of a garden picture lends such fascination to it as does this out-of-doors mirror in the depths of which are reflected the giant pine and stately palm, blue sky and fleecy white clouds, gay flowers, and a host of interesting semi-aquatic plants like Umbrella Grass and Xanthosomas and Alocasias, Ornamental Grasses and what-not. A few small fish-goldfish or just common minnows-will take care of the mosquitoes in summer. 


\section{Group V. The Rose}

No flower today is more popular in the South than the Rose where, with proper cultural attention, blooms of finest quality can be produced the year round. However, so many failures with Roses have been traccablc directly to lack of knowlcdge of the requirements of that plant that we urge all planters to note the following suggestions carefully and be guided accordingly:

First.- Rosc bushes must be planted dcep. The point of union where budded or grafted should be at least 2 or 3 inches below the general soil level. This keeps the roots under more even moisture conditions and serves to discourage sprouting from below the graft or bud. Any shoots that do come up from the old stock should be removed at once. Second.- The soil should be made as rich as possible and deep, and fertilizing should be done several times a year. Roses should be grown in beds, just as a vegetable garden would be handled; don't plant them out as single specimens over the lawn. Enrich the soil with rotted manure, preferably, or other organic material, and if possible make applications of liquid manure during the main growing season. Bone meal is also cspecially valuable for Roses and other flowcring subjects. Third.-Sce that the plants never want for moisture at the roots; keep the soil moist to a depth of 2 feet at all times, if possible. Enough pruning of the Climbers and Teas should be done to keep them free of old wood; more than this if necessary should be done about October in order to encourage Iong flowering shoots. Transplant Roses in November, December or January.

PRICE, of fine 2-year-old, grafted stock, except where otherwise noted, $75 \mathrm{cts}$. each, $\$ 7$ for 1 o.

Abbreviations: Ben., Bengal; Bour., Bourbon; Brac., Bracteata; H.P., Hybrid PerpetuaI; H.T., Hybrid Tea; Læv., Lævigata; Nois., Noisette; T., Tea.

\section{BUSH ROSES}

BRIDE. T. White, of most beautiful form.

DUCHESSE DE BRABANT. T. Shell-pink shaded carmine. A splendid, free-flowering, vigorous sort.

E. E. MARLITT. Bour. Vigorous grower; flowers bright crimson, fragrant.

FRAU KARL DRUSCHKI (White American Beauty). H.P. A splendid pure white Rose of very large size, blooming usually singly on strong stems; in cutting these cut almost to the ground to induce strong flowering shoots.

KILLARNEY. H.T. Semi-double; glowing pink; very fine in bud.

LOUIS PHILIPPE. Ben. A good, thrifty Rose. Crimson blooms on long stems.

MAMAN COCHET. T. A choice Rose; style like Bride; pink, with suffusion of yellow at base of petals.

MARIE VAN HOUTTE. T. Pale yellow, tinged rose. Very vigorous. Flowers large, with pointed buds.

MINNIE FRANCES. T. Might be called an improved Bon Silene. Very fine deep rose-pink; vigorous; splendid Rose for Florida.

MME. CECILE BERTHOD. T. Deep yellow.

MME. LAMBARD. T. Buds rich deep pink, the open flower changing to light shades. Very vigorous.

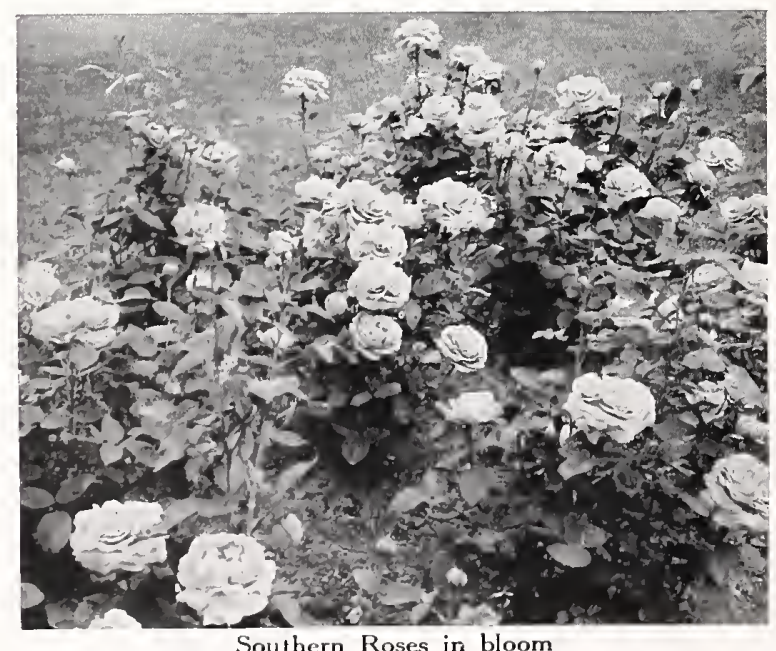

MRS. B. R. CANT. T. Attractive colorings of deep rose on outer petals, inner petals silvery rose, sometimes buff at base; fragrant. Heavy foliage and strong stems.

PAUL NEYRON. H.P. Enormous blooms, perhaps the largest in cultivation. Deep rose-pink, full double flowers on heavy stems; spicy fragrance. Prune back hard in cutting flowers to keep up constant succession.

RADIANCE. H.T. Upright, medium grower with brilliant, rosy carmine flowers. One of the best of the new varieties. This is now separated into two forms, Pink and Red, so please specify in ordering which color is wanted.

WHITE MAMAN COCHET. T. A pure white form of this splendid Rose.

WINNIE DAVIS. T. Apricot-pink, changing to flesh tints; very double.

\section{CLIMBING ROSES}

With few exceptions, the Climbers may be grown as bush Roses by severe or careful pruning.

ANEMONE. Læv. The Pink Cherokee, one of our introductions from England a few years ago. Flowers a beautiful shade of light pink, with a satiny sheen.

CHEROKEE. Læv. A strong native climber; single white flowers usually appearing in January through the spring. $35 \mathrm{cts}$. each, $\$ 3$ for 10 .

CHROMATELLA. Cl. Nois. A good climber; flowers deep yellow. This used to be called "Cloth of Gold."

CLIMBING BRIDESMAID. C1. T. Beautiful pink, with yellow shading in center.

CLIMBING DEVONIENSIS. Cl. T. A strong climber with extra-large llowers, pale pink.

CLIMBING HELEN GOULD. C1. H.T. A fine Rose of a rose-crimson color; very double.

CLIMBING PERLE DES JARDINS. C1. T. Probably the best yellow climbing Rose, supplanting Marechal Niel in its better form and color, holding flowers up on stiffer stems.

ESTELLE PRADEL. Cl. Nois. A lovely pure white Rose of medium size, fragrant.

JAMES SPRUNT. Cl. Ben. An old-fashioned deep red Rose; very double; a good climber.

MACARTNEY. Brac. A rampant climbing Rose with small evergreen leaves; 1lowers large, single, pure white. Makes an impenetrable hedge. 1-yr., $15 \mathrm{cts}$. each, $\$ 1$ for $10 ; 2-y r ., 35$ cts. each, $\$ 3$ for 10.

MARECHAL NIEL. Cl. Nois. The great favorite in the South. Rich yellow.

RAMONA. Læv. The new Red Cherokee, a magnificent production of South California. This is a sport from Anemone, of the same type, but with splendid carmine-crimson flowers.

REVE D'OR. C1. Nois. Buff-yellow and saffron. A grand climber of vigorous habit. 


\section{ROYAL PALM NURSERIES}

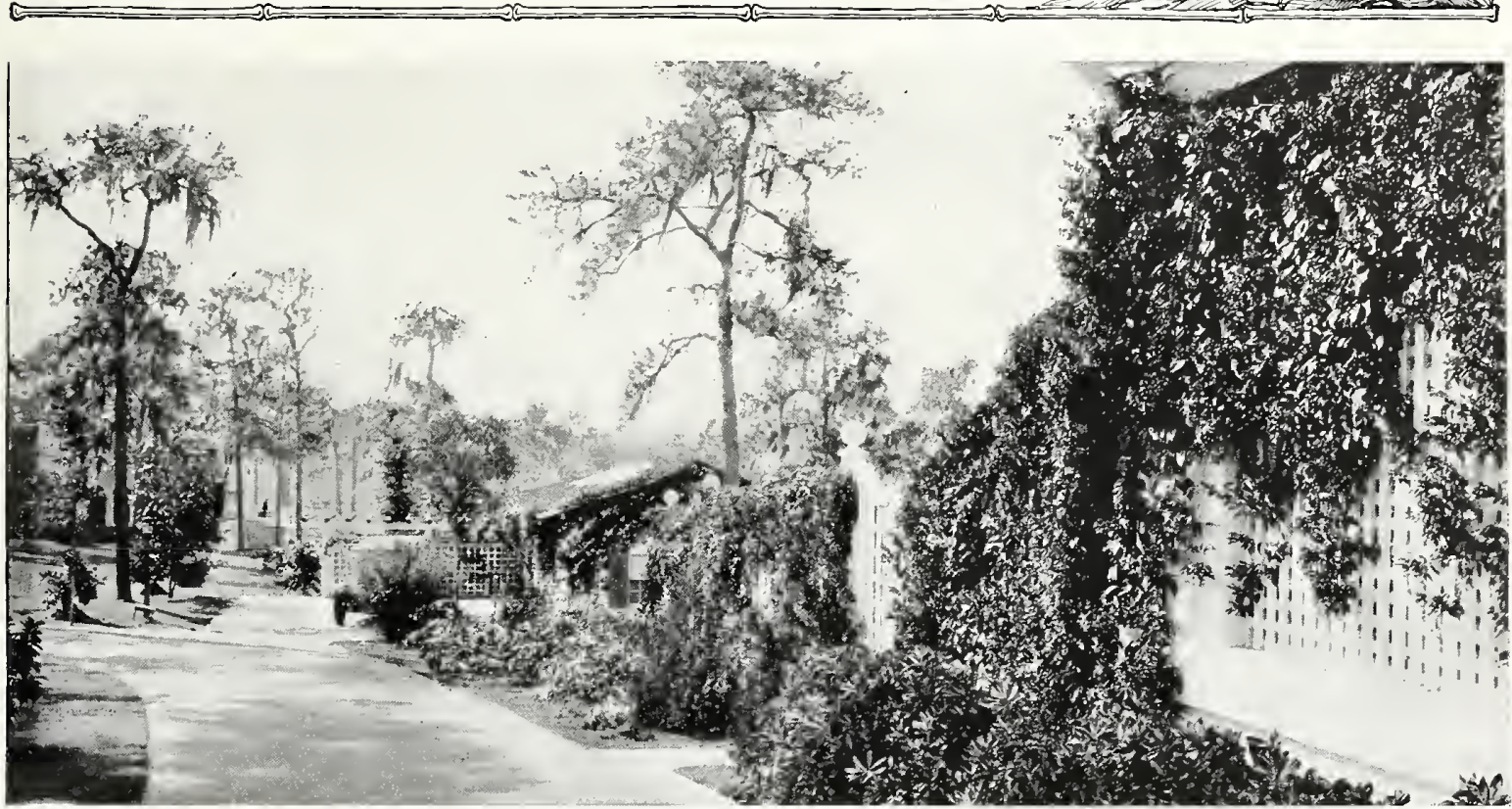

Pyrostegia venusta on garden lattice

\section{Vines and Creepers}

$\mathrm{M}$ ORE AND MORE are planters coming to understand and appreciate the value of "ground-covers" in many situations, either where a good sod is unobtainable or where vines covering the ground would be more attractivc. Vines for this purpose are much used in the North, but the subjects that serve well there do not thrive in Florida under our tropical conditions. Following is a selcctcd list of subjects of special interest and value for covering banks or partially shady ground or other situation where the moistureeither natural or artificial-is sufficient to keep them in a good growing condition until well established: Allamandas both, Bignonias both, Euonymus radicans acutus, Ficus pumila and F. villosa, Gelsemium, Nintooa, Pyrostegia, Smilax, Trachelospermum, Purple Trailing Lantana, Zebrina pendula.

Trees, Palms and shrubbery of course come first, as they form the framework of the garden picture, but more finish will be needed later and vines are very valuable for this purpose. On the home they serve to soften the sharp angles and lines of the building and by the very nature of their growth they become identificd with the architecture of the structure itself, making it a more normal and intimate feature of the landscape. They help to make unsightly but usually necessary fences more tolerable, hiding their artificial and abnormal characteristics. By erecting a framework on which they can climb, they soon form a quick and efficient screen for unsightly views or buildings, and on pergolas, arbors, and the like, they are naturally invaluable.

In planting they should be given the same consideration in respcct to preparation of the ground and fertilizing as would be accorded any shrub. Around buildings they should not be planted in the drip of the eavcs, as with our heavy rains and light soils, the earth is soon washed away from the roots, especially here in Florida.

A very suitable planting arrangement, where one wants the vines to quickly shade a window, is to erect a double inverted U-support of small pipe, elbows used at the turns, one "U" close to the house wall and window, the other farther out, and wire stretched between on which the vines can be trained. The ends of the pipe should be sunk in small concrete blocks to steady the supports.

Special Notice. Plants in this Department may be transplanted at any timc of the year.

Those marked $\mathbf{T}$ are tropical or subtropical and are suited to grcenhouse, living-room, warm offices, for planting out in the Tropics and the extreme lower South, where slight protection may be necessary. Those marked $\mathbf{H}$ are more hardy and suited generally to Florida and Gulf Coast planting. All need a wire or other support except Bignonias, Euonymus, Ficus, Hedera, Pyrostegia and Tecoma; thesc cling to any solid support and are ideal for covering brick, stone, or cement-fmished walls, lending a charming air to homes, churches, schools, or any buildings, robbing them of the forbidding, prison-likc aspect of the usual modern structure.

For fragrance try Deguelia, Nintooa, Pereskia, GeIsemium, Jasminum, Trachelospermum, Cereus.

The following vines are in Bloom in the November to March period: Bougainvillea, Bignonia, GeIsemium, Tecoma, Jasminum, Pyrostegia, Cereus, Ipomœa, Trachelospermum.

For coast planting try Cryptostegia, Passiflora, Trachelospermum. 


\section{Group I. Vines Which Stick to Any Good Surface Unaided}

This elass of vines will adhere to wood, briek, eement, and the like-though we do not reeommend them for wood that needs painting from time to time, for obvious reasons.

BIGNONIA UNGUIS-CATI. Cat's Claw Vine. H.

though of delicate appearance, exceptionally line lor covering stone or brick houses of darker shade or white, but does not harmonize well with most shades of yellow brick. The splendid bright golden yellow flowers are about 2 inches across and borne in profusion in early spring. $15 \mathrm{cts}$. each, $\$ 1$ for 10 .

B. VEnUSTa. See Pyrostegia.

EUONYMUS RADICANS ACUTUS. H. A splenfoliage and of vigorous growth when established. Much better than the old $E$ radicans type. It does well in a variet of soils and clings to any support unaided or will make a good ground-cover. 35 cts. each, $\$ 3$ for 10. FICUS PUMILA ( $F$ repens). Creeping or Climbing Fig. grown in Florida for covering stucco, brick, or other masonry. The leaves are small, dark gray-green, and with the slender woody growth stick very flat and close to the surface, making a network or tracery of green over the entire surface. When first planted it should receive special care and attention, as the small plants are easily washed out when watering against the wall. We suggest placing three short pieces of wood around it, partly sunk in the ground, to make a little box-like effect, to prevent such washing. Once established, after a few months, it makes a very vigorous growth and soon covers a considerable area. When grown on walls it will stand a great deal of frost. Be sure to remove all soil having cement from building mixed with it, before planting. $35 \mathrm{cts}$. each, $\$ 3$ for 10 .

F. VILLOSA. H. A stronger grower, with larger leaves than the preceding species, and perhaps not so hardy. $35 \mathrm{cts}$. HEDERA HELIX. English Ivy. H. Europe to Asia.

uable for its handsome, large, evergreen foliage. It clings well to brick or masonry but in Florida should be planted only on the north or shady walls of buildings. $35 \mathrm{cts}$. each, $\$ 3$ for 10 . PYROSTEGIA VENUSTA. (Bignonia venusta.)

doubt this vine attracts more attention in Florida than any other, even than the bougainvilleas. In many sections of South Florida it covers huge pine trees, fences, buildings and the like, and when in bloom in winter appears to be a mass of flames. The vine is exceptionally vigorous, reaching 80 feet

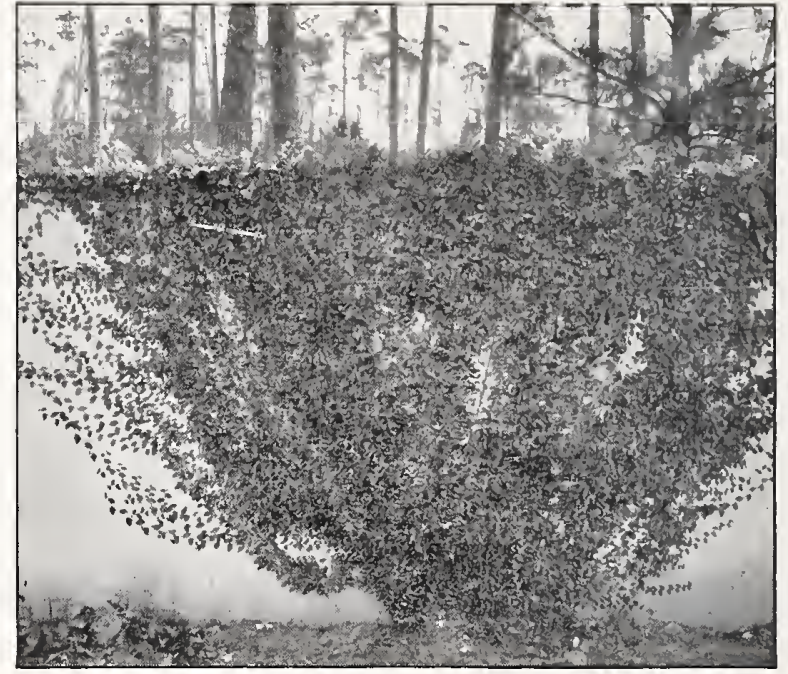

Ficus pumila in delicate tracery on stucco wall

or more, and clinging tight to any support unaided after securing a little foothold. The foliage is a good green and the orange-red tubular flowers are borne in dense clusters and greatest profusion in winter and oftentimes are followed by a lighter crop in May or June. $35 \mathrm{cts}$. each, $\$ 3$ for 10; heavier, 50 cts. each, $\$ 4.50$ for 10; extra large, in light boxes, $\$ 1$.

TECOMA RADICANS. Trumpet Creeper. H. This hardy vine of the North is found growing while a comparatively slow grower, it succeeds exceptionally well under cultivation. The foliage is compound - and deciduous - and the dark orange-red flowers, 2 inches across, are borne in profuse clusters. It does especially well when planted near trees, over which it scrambles easily. When in leaf and flower it is attractive and when without foliage, it is not conspicuous. $25 \mathrm{cts}$. each, $\$ 2$ for 10.

\section{Group II. Vines That Are Valuable for Use on Palmetto and Other Tree Trunks}

It frequentiy happens that there are not suffieient opportunities for the use of vines on the buildings of a property, in whieh case "serub oaks" and other poorer specimens of trees, as well as tall Palmetto trunks, ean be utilized to very good advantage. In faet, not only ean one get the benefit of the vines, but the trees are invested with a eharm and eharaeter that they would frequently otherwise laek. The following list is suggested as espeeially adapted to this purpose, but they will all require a little start in the nature of a wire or stout string fastened to a stake driven in the ground and also to the tree trunk. Onee started the vines will take eare of themselves. All in Group I ean be utilized, though not so desirable as the following:

BOUGAINVILLEAS. To those still unfamiliar yarieties of this rlorious subject the name "Bonderful new brings only to mind the old-fashioned magenta-purple $B$. glabra sanderiana. But there are some new colors now that are so wonderful in tone and value and so very distinctive that we urge every planter to carefully consider the following list. Needless to say they should not be planted together-one should decide on the color effect wanted at any given point and plant only to the variety that will give it most successfully.

B. BRAZILIENSIS. T. Brazil. Brilliant light purple; flowers in late spring most heavily. For general description, see B. glabra sanderiana. $\$ 2$.

B., CRIMSON LAKE. T. By most people who know it, this is considered the finest coloring of all - a rich, glowing crimson, later ovcrcast with purple shades, altogether beyond adequate description. It is espccially useful for planting at pergolas and for running up into small trecs, and the like. The brilliant red color of this, mingling with the gray-green foliage of the Turkey Oak of the high sandy ridges of Central Florida, is particularly attractive. $\$ 2$.

B. GLABRA SANDERIANA. Paper Flower. T. Brazil. A very showy-flowered woody climber covered with great masses of magenta-purple "flowers" (in reality the bracts, with tiny yellow flowers in center) which are borne in profusion during the greater part of the year, more especially during the winter and spring months. It may be handled either as a shrub, in which form it is particularly effective as a low hedge running along the top of a cement retaining wall, or as a vine on peryolas, small trees, and the like, or it may be trained as a large shrub in standard form by proper pruning. It has frequently been used with telling ellect to cover old or unsightly fences. 35 cts. each, $\$ 3$ for 10 ; larger, $50 \mathrm{cts}$. each, $\$ 4$ for 10 ; extra large, price on application. 


\section{ROYAL PALM NURSERIES}

BOUGAINVILLEA SPECTABILIS. T. Brazil. This variety has "flowers" of much greater size and deeper purplereally finer than the preceding. It does not bloom so young, however, and flowers in spring only. $\$ 1$.

B. SPECTABILIS LATERITIA. T. True red is the nearest description of this color that could be given-not scarlet, nor deep pink, but real red. In shade it assumes a somewhat lighter shade, of course. The bracts are large and Iike all of this genus are borne in greatest profusion, making veritable bouquets of bloom during the winter blossoming season. $\$ 3$.

CEREUJS BOECKMANNI. Night-Blooming Cereus. across, that will stand freezing temperatures. $50 \mathrm{cts}$.

C. TRIANGULARIS. T. This is also a Night-blooming Cereus, resembling the preceding, and sometimes called Strawberry Pear from the handsome fruit. Stems three-sided. Flowers very fragrant, from 6 to 8 inches across. $35 \mathrm{cts}$.

GELSEMIUM SEMPERVIRENS. Carolina Yellow

States. Wessamine. H. Southeast United foliage and a profusion of pure yellow, bell-shaped, very fragrant flowers in winter. Very desirable for covering fences and also as a ground-cover. 25 cts. each, $\$ 2$ for 10 ; extrastrong, 35 cts. each, $\$ 3$ for 10 .

JASMINUJM GRANDIFLORUM. Catalonian Jasmine. $T$. India. Beautiful bright green pinnate leaves, and intensely fragrant flowers, pure white when open. Evergreen and almost a constant bloomer. 50 cts.

LONICERA SEMPERVIRENS. Coral Honeysuckle. UICLR H. Native. High-climbing, broadEspecially attractive when interplanted with other vines for contrast. $35 \mathrm{cts}$. each, $\$ 3$ for 10 . NINTOOA JAPONICA. Hall's Japan Honeysuckle. handsome foliage. Fine for covering rocks, the ground, or for trellises. The flowers are pure white, changing to creamy yellow, fragrant and are almost everblooming. We have found it particularly interesting when used to scramble up the smooth trunks of palmetto trees, serving to soften the lines and stiffness characteristic of the single specimens on lawns. 25 cts. each, $\$ 2$ for 10 ; heavier, 35 cts. each, $\$ 3$ for 10 .
PITHECOCTENIUM CLEMATIDIUM. H. South America. Attractive climbing plant with rather delicate foliage and 35 cts. each, $\$ 3$ for 10 .

PYROSTEGIA venusta. See page 34.

THUNBERGIA GRANDIFLORA. T. India. This in popularity in Florida than any other subject - and once you see it you will understand why. It is a very rapid grower, making a showing quicker than any other woody vine we know. under normal conditions, with beautiful, large, soft, pointed Ieaves and a succession of splendid pale lavender-blue flowers throughout the year. The individual blossoms are fully 3 inches across, resembling a bignonia in form, and hang pendant in clusters of several each. This is one you will love on first sight, and no matter where you live in peninsular Florida you should have one if you can make suitable place for it-even if frozen down, it comes right up and is soon blooming freely again. 50 cts. each, $\$ 4.50$ for 10 ; Iarger, $\$ 1$ each.

\section{TRACHELOSPERMUM JAS M INOIDES.}

mine. H. China. If you have a palmetto tree out on your Iawn-especially one having the boots of the leaves still on the trunk-plant one of these vines against it and see how well you like it in a year or two. You won't take it out for anything! Once given a little start it climbs readily enough, and vigorously. The foliage is small, the leaves thick and leathery and dark green. The flowers, borne only in the spring, are produced in uncountable numbers, pure white and intensely fragrant. 75 cts. each, $\$ 7$ for 10 .

T. JASMINOIDES VARIEGATUM. H. Leaves variegated with white and sometimes with pink. \$1.

VANILLA PLANIFOLIA. Commercial Vanilla. T. any real decorative value it has, this tall-climbing, succulent vine that furnishes the Vanilla Beans of the trade is a true orchid. It puts out roots from the stems by which it fastens itself to any support and makes an interesting addition to shady woodland or thicket in extreme South Florida. $50 \mathrm{cts}$. each, $\$ 4.50$ for 10 .

\section{Group III. Vines for Porches, Trellises, Etc.}

AIl of Group II can be used as well as the following:

ALLAMANDA HENDERSONII. T. One of the ALLAMANDA most gorgeous tropical plants grown in Florida; may be trained either as a vine or shrub, and will grow well up into the southern edge of our Gulf States, as the loss of top by frost is very quickly remedied by a few weeks of spring weather. Glossy green, broad leaves; flowers constantly produced 4 to 5 inches across, pure golden yellow. Makes a charming combination with strong blue tones. 35 cts. each, $\$ 3$ for 10 ; larger, 50 cts. each, $\$ 4.50$ for 10 .

A. WILLIA MSII. T. This is similar to preceding species except in size of flower, which is only about 3 inches across, and sometimes a trifle fragrant. Exceedingly floriferous. 35 cts. each, $\$ 3$ for 10 ; larger, 50 cts. each, $\$ 4.50$ for 10 .

ANTIGONON LEPTopus., Rosa de Montana or II 1 G "Pink Vine." T. Mexico. Plant one of these against that ugly fence corner and see the bees come tumbling over themselves to compete for the nectar contained in the glowing pink flowers! The vine is a vigorous grower, with beautiful heart-shaped leaves and large, graceful racemes of flowers during most of the year in Florida. Not attractive during coolest weather. 25 cts. each, $\$ 2$ for 10 ; larger, 50 cts. each, $\$ 4.50$ for 10 . ASPARAGUS $\begin{gathered}\text { FALCATUS. ST. } \\ \text { climbing piant, with dark green }\end{gathered}$ coarse leaves and masses of scented white flowers at intervals. Shoots attain a length of 20 to 25 feet. Fine outdoors in Florida. $50 \mathrm{cts}$. each, $\$ 4.50$ for 10 ; larger, $\$ 1$ each.

A. PLUMOSUS. (Erroneously called "Asparagus Fern.") ST. A very fine, fern-leaved climbing plant, particularly adapted for bouquets and all cut-flower work, etc. Lasts for days without water. May be grown outdoors in Florida and warm regions. A fine pot-plant for any climate. $15 \mathrm{cts}$. each, $\$ 1$ for 10 ; heavier, $25 \mathrm{cts}$. each, $\$ 2$ for 10 . Extra heavy, $35 \mathrm{cts}$.
BEAUMONTIA GRANDIFLORA. T. India. A heavy foliage and clusters of immense trumpet-shaped white flowers, resembling Easter Iilies, only larger, coming in early spring. A magnificent subject for South Florida planting, especially on massive pergolas. Plants layercd. $\$ 1$.

BIGNONIA SPECIOSA. H. South America. A BI 1 A magnificent vine, with glossy, dark green leaves and great clusters of large, purplish, trumpet-shaped flowers blooming here from March to May. A fast grower and free bloomer. 35 cts. each, $\$ 3$ for 10.

B. VENUSTA. See Pyrostegia, page 34.

CLERODENDRUM THOMSON E. (C. balOuick-growing; of unusual merit; flowers bright scarlet, cnclosed partly in a bag-like calyx of pure white. The flowers last for many weeks and are produced in quantity. $35 \mathrm{cts}$. each, $\$ 3$ for 10 ; Iarger, $50 \mathrm{cts}$. each.

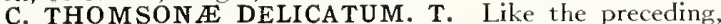
except that the calyx is greenish, instead of white, and turns a reddish bronze with age. $25 \mathrm{cts}$.

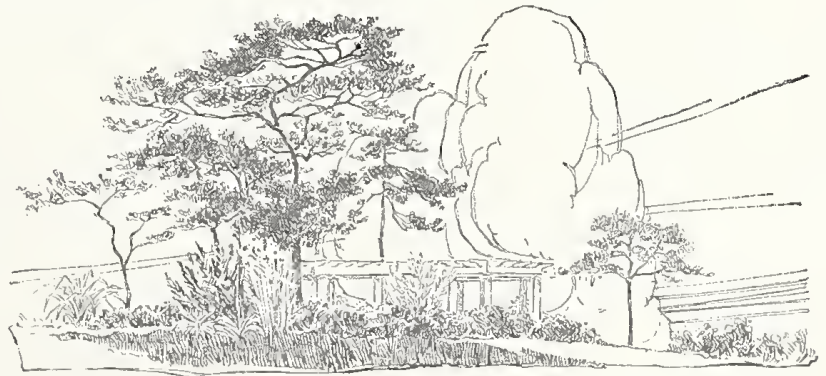




\section{VINES AND CREEPERS continued}

CRYPTOSTEGIA MADAGASCARIENSIS. Rubber Vine. T. Madagascar. A strong-growing, woody vine that with a little support will make a shrub-like growth. Leaves glossy green and showy, flowers are pinkish, $2 \frac{1}{2}$ to 3 inches across. $35 \mathrm{c}$. each, $\$ 3$ for 10 .

DEGUELIA TIMORIENSIS. T. A very vigorous pure white, sweet-scented flowers in enormous profusion in ummer and autumn, 25 cts.

DIOSCOREA SP. Air Potato. T. Rampan

Prower, suitable for porches, or where nerved. 25 cts. each, $\$ 2$ for 10.

GLORIOSA SUPERBA. Climbing Lily. H. Africa a A gorgeous lily-like plant climbing from 6 to 10 feet high, and bearing a profusion of scarlet and yellow flowers during the summer and fatt. Is a first-class ornament for a screen or to grow over shrubs or palm trunks, but prefers full sun exposure. Tubers available onty in winter and early spring. $25 \mathrm{cts}$. each, $\$ 2$ for 10 .

G. VIRESCENS. H. More dwarf than preceding, flowering earlier, about same in color of bloom. Tubers available in winter and spring. $25 \mathrm{cts}$. each, $\$ 2$ for 10 .

IPOMOEA HORSFALLIÆ BRIGgSII. Brazilian abundance of deeply cut, waxy, dark green leaves. Its greatest period of bloom is December, but for weeks in advance the showy, deep carmine-crimson flower buds are swelling. A second though lighter crop of bloom comes in June. Rare and exceedingly desirable. \$1.

IASMINUM NITIDUM. T. Admiralty Islands. shining foliage and white, very fragrant flowers. An excellent greenhouse subject as well as for outdoor planting in South Florida and the Tropics. One of the most choice climbing subjects we know. 50 cts. each, $\$ 4$ for 10.

J. PUBESCENS. T. A shrubby vine, more often used as a shrub than as a vine here in Florida; attractive foliage and habit of growth, with a profusion of white flowers borne throughout the year in crops. One of our most desirable subjects. Strong stock, 35 cts. each, $\$ 3$ for 10 ; heavier, 50 cts. each.

J. SAMBAC, Arabian Jasmine. India. A climbing shrub much cultivated in the Tropics. The following varieties are improved forms of very intense fragrance:

J. SAMBAC, Grand Duke. T. A very double-flowered Jessamine. The blooms are frequently $21 \%$ inches wide and intensely fragrant. Foliage is dark green and shining. $50 \mathrm{cts}$. each, $\$ 4.50$ for 10 .

J. SAMBAC, Maid of Orleans. T. Semi-double flowers, $11 / 4$ to 2 inches wide, very fragrant; constantly in flower. Fine, 50 cts. each, $\$ 4.50$ for 10 .

LANT ANA, Purple Trailing. T. This fine-foliaged ground-cover for sloping banks and like situations. The mauve-purple flowers are in roundish umbels, very numerous and borne at all seasons of the year. $25 \mathrm{cts}$. each, $\$ 2$ for 10 . PASSIFLORA edulis and P. laurifolia. See page 50.

PERESKIA AcUlEATA. Lemon Vine, or Barbados Gooseberry. T. A climbing cactus with true leaves anó producing edible fruit. Stems fleshy, with spines at the base of each leaf. Very fast grower; much uscd as a stock upon which to graft epiphyllums and other low-growing cacti. Flowers borne periodically in immense numbers; $11 / 2$ inches wide, of a creamy white, with a grcen tinge. 25 cts. each, $\$ 2$ for 10 .

P. SPECIES. T. New. This resembles somewhat the Lemon Vine, but is dwarf and much more delicate. Flowers greenish white about an inch across. $25 \mathrm{cts}$. each, $\$ 2$ for 10 .

PETREA volubILIS. Queen's Wreath. T. Amerievergrcen, of medium size and produced on twining woody growth. The flowers are bornc in profusion in longbranched panicles of exquisite shades of purplish blue, the calyx grayish blue, with the corolla almost royal purple. The vine is in bloom throughout the warmer months, though at its best in spring and early summer. Strong plants from layers, $\$ 1$.
PORANA PANICULATA. Snow Creeper. T. India. terminating with a panicle of innumerable small white flowers. $\$ 1$.

SMILAX, Greenbriar or Bamboo Creeper. H. Native. Don't confound the name with the greenhouse vine, myrsiphyllum. This hardy plant is prickly and bears quantities of black or green berries; the cut masses of vines are used in large decorations, being shipped from the South largety. Most interesting as a chimber over low oak trees, and the like, where it will make a splendid mass of bright green foliage. Strong roots, $25 \mathrm{cts}$. each, $\$ 2$ for 10 .

SOLANUM SEAFORTHIANUM. T. West Indies. A medium-sized delicate vine with combunches of pale lavender-blue flowers, which are followed by scarlet berries greatly liked by birds. Called in Mexico "Tomatillo." Especially attractive when grown on garden or other screen lattice work. $25 \mathrm{cts}$. each, $\$ 2$ for 10 .

S. WENDLANDII. T. Costa Rica. A very large vine with coarse pinnate leaves, but most elegant, likac-blue, sometimes skv-blue, flowers borne in great clusters 10 to 15 inches across, and lasting well. This is one of the quickest growing vines we have and what is of more especial value it does exceptionally well on the poorest lands, growing with greatest vigor on the seashore on newly fitled-in land that is little better than plain beach sand. We recommend it highly for any place where it is sufficiently hardy. $35 \mathrm{cts}$. each, $\$ 3$ for 10 .

TECOMA CAPENSIS. T. South Africa. A stronggrowing shrubby climber, with elegant pincarlet-orange, showy flowers. $35 \mathrm{cts}$. each, $\$ 3$ for 10 ; heavier, 50 ets. each, $\$ 4.50$ for 10 .

T. RICASOLENIA. T. Attractive vine with flowers of good size, white with reddish striped throats. 35 cts. each, $\$ 3$ for 10 . THUNBER GIA FRAgRANS. T. India. This lovely slender-stemned, twining vine with its dark green leaves and pure white flowers is valuable as a ground-cover with shight overhead protection. Is doing nicely in pine sapling growths. $25 \mathrm{cts}$. each, $\$ 2$ for 10 .

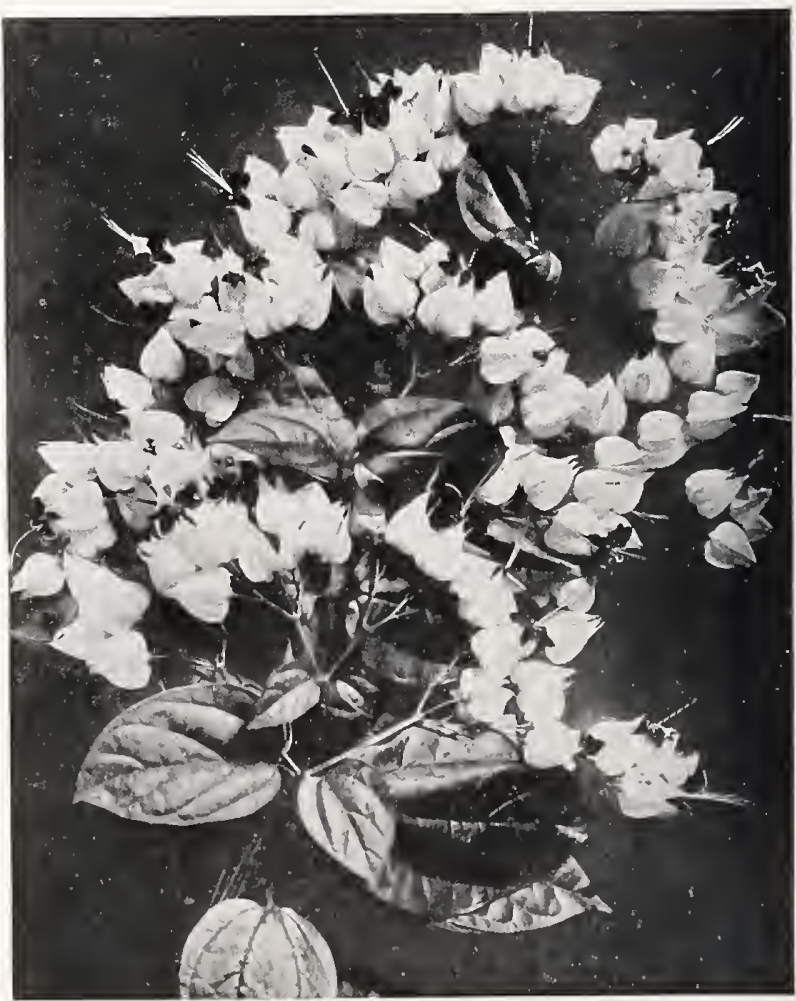

Clerodendrum thomsonæ. See page 35 


\section{ROYAL PALM NURSERIES

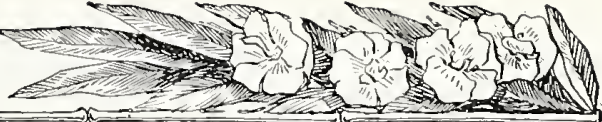

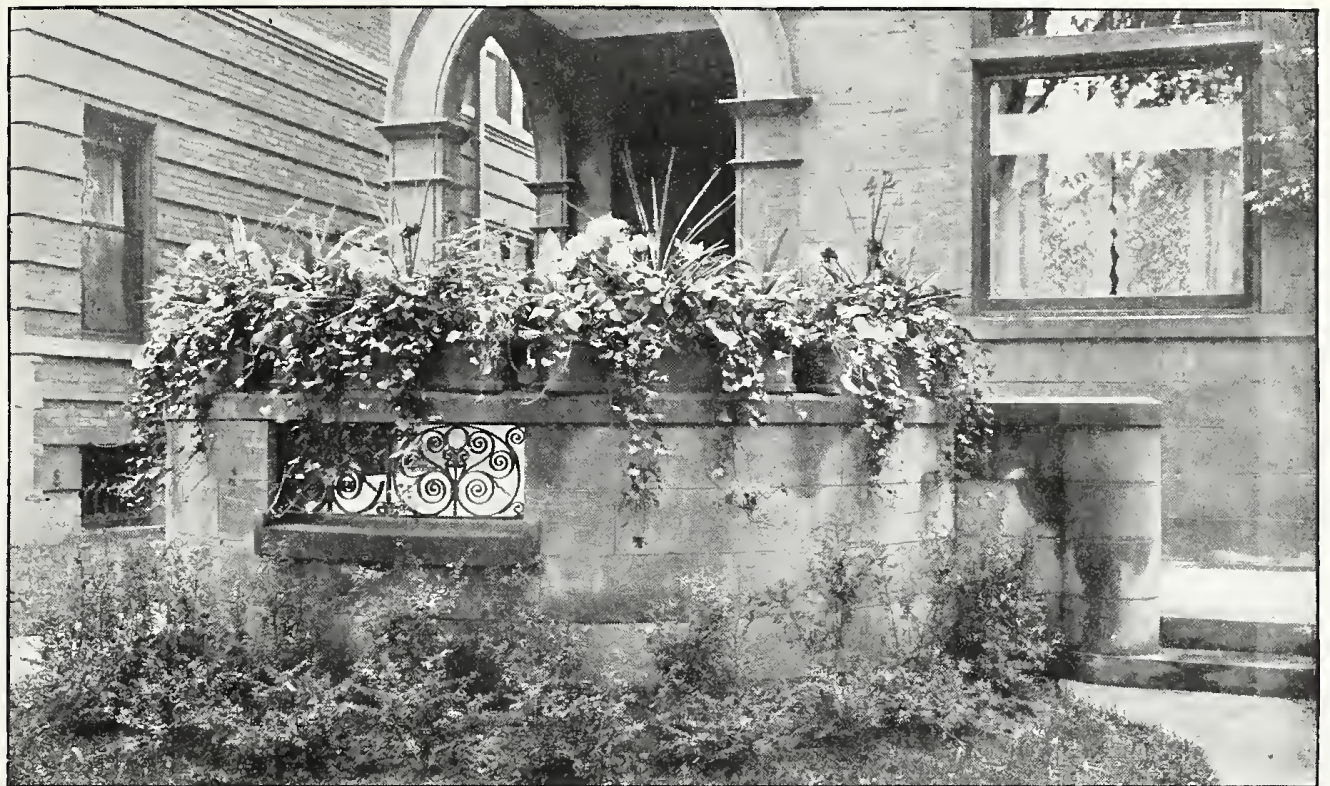

The charm of the well-planted porch-box

\section{Decorative Subjects}

$\mathrm{T}$

HE PROPER USE of this class of plants is probably as little understood as that of the Tubcrous and BuIbous type, and because of their prominent characteristics and the fact that they are used rather as specimen subjects occupying prominent positions, it becomes all the more necessary that special care and thought should be exercised in planning for their positions in the Iandscape scheme. While they can frequently be used for grouping, they are not as a rule adapted to mass plantings - as a matter of fact, they are most effective when used in connection with mass plantings. Frequently continuous masses of foliagc tend to become more or less monotonous and lacking in that tropical definition that it is so important to secure in the Florida and southern garden, and the use of such plants as Agaves, Pandanus, Yuccas, etc., planted at the ends of Iong groups along their undulating lines, will serve to offset this and bring out expression as no other classes of subjects can.

\section{Group I. Plants for Securing Picturesque Tropical Landscape Effects}

\section{AGAVE. The Agaves, or Century Plants, are among} AGA VE. the most striking and picturesque that can be used for securing tropical effects in the southern garden. They are particularly valuable when used in conjunction with the ornamental grasses and the bamboos, for which they make a pleasing foil in texture yet preserve the harmony of growth. We suggest them as single specimens in corners of masses or terminations of long borders or in small groups. As they thrive on the thinnest and poorest of our sandy lands the range of usefuiness is very great. Where very formal effects are desired, as in vases at entrances or long terraces, they are invaluable and cannot be excelled. Several species are of economic value in the Tropics, but not as yet in the United States.

A. MIRADORENSIS. A rare form of particular value in patio and similar situations where its small size is well suited. The leaves are short and compact, recurving beautifully, the whole plant growing about 2 feet high and sending up a flower-stalk about 12 feet high. $\$ 1$.

A. NEGLECTA. Rich, blue-green leaves, wide and gracefully recurved. The handsomest large sort in our collection, and fairly hardy. A magnificent plant, beautiful in all sizes, and surpassingly fine for all decorative purposes. Fine plants, with beautiful leaves. 25,50 , and 75 cts.

A. SISALANA. Sisal Hemp. Mexico. Unlike the former, the leaves of this sort are straight and swordlike in character. They are more severe in effect and therefore can be used to better advantage in securing truly formal effects. This is the species that has proved so valuable in Yucatan where it is grown for its high-grade fiber. We can furnish this in large quantities to those interested in starting extensive plantings. Prices on application. Other prices, 12 to 18 inches high, at 25 to $50 \mathrm{cts}$; smaller, $15 \mathrm{cts}$. each, $\$ 1$ for $10, \$ 6$ per 100 .

CARTCA PAPAYA. While this is most generally value because of its Iarge, palmate leaves which are handsome in form, as well as for its upright habit of growth in single trunk. See page 50.

EUPHORBIA PULChERRIMA. Poinsettia. This wonderful plant, now so generally

grown throughout Florida, even where subject to continual freezing, is too common to need description. Because of its Iarge scarlet bracts, it is a particularly hard subject to use satisfactorily with other colors, and great care should be exercised in its use. As the plants lose their green leaves, as a rule, they are Iikely to look like leggy scarecrows just at the time we would have them at their best. Our suggestion therefore would be that they be always planted in the rear of heavy borders of green-leaved plants, from which they can thrust their brilliant heads of flaring red bracts. (The plants we offer are simply nursery stock, and not florist's stock in bloom.) 25 cts. each, $\$ 2$ for 10

WHITE POINSETTIA. A charming addition to the genus; a great novelty as yet. $50 \mathrm{cts}$.

NOLTNA TUBERCULATA. A splendid plant, resemNOLIIA bling a yucca or dracena, but with an enormous bulbous base from which the trunk runs up very slenderly, and is an effective subject growing up to 8 feet or more in height. $\$ 2$. 


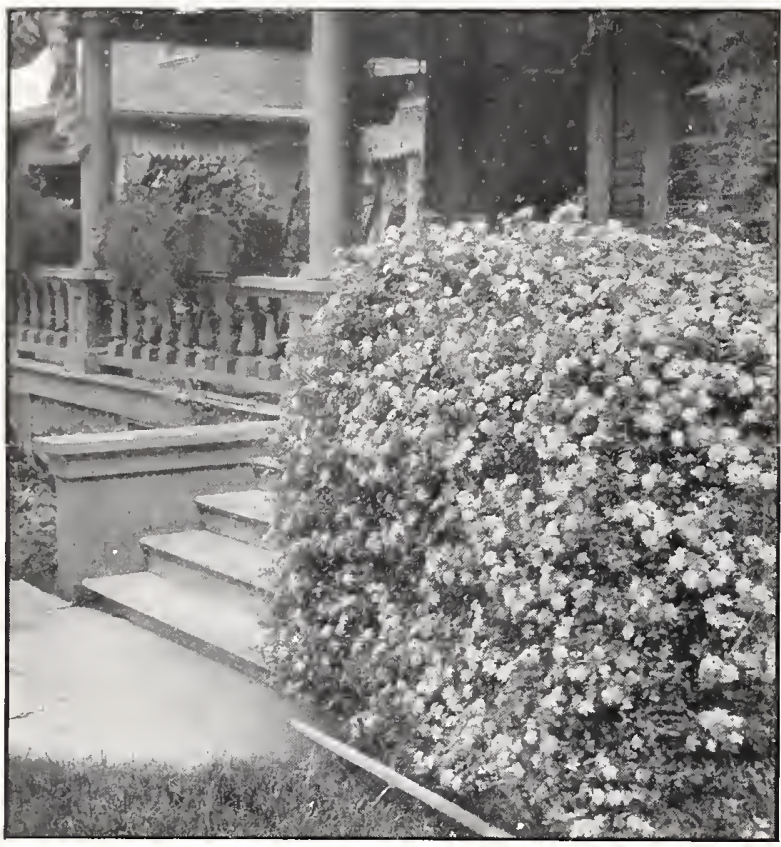

Purple Trailing Lantana, for porch-boxes
DECORATIVE PLANTS FOR TROPICAL LANDSCAPE EFFECTS, continued

PANDANUS UTILIS. Screw Pine. This wellplant when small, having variety resembles a pineapple the edres. ful pars. A very symmetrical and handsome plant. Bcautiplants in several sizes. $75 \mathrm{cts}$. and $\$ 1$.

P. VEITCHII. A magnificent plant, the broad leaves stripcd with creamy white and more ercct than the preceding. Of special value for securing tropical effects in patios and for use in vases, window-boxes, and the like. $35 \mathrm{cts}$, and $\$ 2$.

RAVENALA MADAGASCARIENSIS. Travelers' Tree. Madagascar. Has a trunk like a palm, with large, heavy, smooth leaves, two-ranked, someYUCCA ALoIfolia. Spanish Bayonet; Spanish YUCCA Dagger. Probably noc hardy north of Middle Georgia. Flowers resemble those of $Y$. flamentosa but are borne on a shorter stalk. Stem sometimes 10 to 20 feet high. Very ornamental even when small. Will bear neglect. This is an interesting plant for border-work, introducing along streams, and in other ways adding interesting and tropical touches to the landscape. Because of its great resistance to salt spray and considerable wind it is highly useful in the development of the water-front garden along the seashore, especially on newly filled land. 25 cts., 50 cts., and $\$ 1$.

Y. ALOIFOLIA VARIEGATA. Leaves striped with white. Rare. \$1.

Y. FILAMENTOSA. Bear-Grass. A low-grower with tough leaves about a foot long. The tall flower-spikes stand erect to a height of 4 to 6 feet, carrying a large number of beautiful greenish white bell-shaped flowers about 2 inches across. 35 cts. each, $\$ 3$ for 10 .

\section{Group II. Window- and Porch-Box Plants}

This is another much-neglectcd phasc of ornamental gardcning in Florida. In spite of the fact that nowhere in the country can so large a number of plants be successfully grown and for so long a pcriod in porch- and windowboxcs as here, the avcragc northern town of any enterprise in gardening mattcrs makes far more and better showing during the few summer months than we do. And there is nothing difficult about the whole matter-anyone can mix up some good rich loamy soil and put it in boxcs that anyone a littlc handy with tools can make-and after that there is practically nothing to it, but to see that the plants never suffer for watcr. Add a tablespoonful or so of ordinary household ammonia to cach bucket of water every couple of wecks, espccially as thc plants fill up the boxes with roots-it will be found a great hclp in kceping them green and growing well.

\section{ASPARAGUS PLUMOSUS. This vigorous-grow-} ing plant, with foliage of feathery delicacy, frequently misnamed "Asparagus Fern," is a subject of special value for this purpose. See, also, page 35.

A. SPRENGERI. An indispensable addition to the florist's collection, particularly for growing in baskets, pedestals, and window-boxes, so that thel ong shoots may hang. It makes an exquisite combination of green foliage and scarlet berries. 15 cts. each, $\$ 1.25$ for 10 ; Iarger, 25 cts., and $\$ 1$; baskets, $\$ 2.50$. AZALEAS for shady situations. See page 25.

BEGONIA MACROPHyLLA. Strong-growing species BEG NIA with leaves of enormous size, flowers white on tall stems above the foliage. $25 \mathrm{cts}$. each, $\$ 2$ for 10 .

B. SEMPERFLORENS. A small plant with almost white flowers. $15 \mathrm{cts}$. each, $\$ 1.25$ for 10 .

CUPHEA Hyssopifolia. Mexico. A small, leaves and lavender flowers. $35 \mathrm{cts}$. each, $\$ 3$ for 10 . EPIPHYLLUM TRUNCATUM. Crab-claw Cactus.

growths falling downward over the sides of pot or hanging-basket. Flowers come in midwinter and are very freely produced, of a rich, deep pink. $35 \mathrm{cts}$.

EUPHORBIA SPLENDENS. A fleshy-stcmmcd low-growing plant with dull spines along its full length; admirable for a sunny position on rocks, in vases, and the like. Flowers rich scarlet. $35 \mathrm{cts}$.

FERNS. Exccedingly uscful for window-box planting where not too sunny. Refer to pare 39 for a choice collection. Note particularly the Ncphrolepis.
HEMIGRAPHIS COLORATA. A purple-leaved plant of trailing habit. Fine

for baskets or as a cover plant, but needs heat in winter. $15 \mathrm{cts}$. each, $\$ 1.25$ for 10 .

LANTANA, PURPLE TRAILING. Without question window-box with its fine foliage and good trailing habit and heads of bright nauve flowers. We recommend it particularly for use with Asparagus sprengeri. 25c. each, $\$ 2$ for 10.

MESEMBRYANTHEMUM R OS E U M . plant, admirable for window-boxes or raised beds, standing either full sun or partial shade. Flowers pink, about an inch across; leaves are fleshy. $15 \mathrm{cts}$. each, \$1 for 10.

PANDANUS Utilis and Veitchii. See above. PHYLLAUREA variegata. $\begin{gathered}\text { Crotons. Be- } \\ \text { cause of their bright colors, }\end{gathered}$ especially when grown in full sun, they have proved very popular for window-box use. See Shrubs, page 31. PHYLLOCACTUS LATIFRONS. Queen Cac-

growing 8 to 10 feet high; the stems 4 to 5 inches broad, and flat. Flowers are a fine creany white, with a reddish tube, produccd at night. $50 \mathrm{cts}$.

RUSSELLIA. See Shrub Department, page 28.

ZEBRINA PENDULA. Wandering Jew. A succulent creeping plant with green and yellow foliage overspread with a silvery sheen, purple underneath. This is uscful for baskets and window-boxes, and in the open in South Florida as a ground-cover in shade under trees. $10 \mathrm{cts}$. each; sufficient for small basket, 25 cts. 


\section{Group III. Miscellaneous}

AECHMEA MARIÆ-REGINAE. Costa Rica. A The leaves are thin and light green; spikes and flowers brilliant scarlet, the individual flowers tipped with light blue. $\$ 1$.

\section{DENDROPOGON}

USNEIODES. Long Moss, Gray Moss, or Spanish Moss.

South. Very effective in decorations. The effect of this moss hanging on the trees in the South is indescribable. Will stand sharp freezing unharmed. A nice quantity for 10 cts.; 25 cts. per pound.

TILLANDSIA. Air Plant or Wild Pine. A very the large genus of ornamental plants of the easiest culture, requiring only to be attached to a block of wood and to be watered with the other plants. Tie with wire on rough bark; the plants hold water in their leaves. We list only native Florida species.
T. CASPITOSA. A species with long, grass-like leaves varying in color from gray to red; usually found in moist places. 15 cts.

T. FASCICUlata ( $T$. bracteata). One of the Iargest Wild Pines or Air-Plants. Full-grown plants are 1 and 2 feet in diameter and height, spikes often 18 inches or more in length; the large, brilliant, crimson bracts and flower-stalks and purple blossoms are very showy, and remain beautiful for weeks. A most valuable plant for conservatory or bay window, enduring a low temperature (though but little frost); requiring no care except an occasional watering. Attach to wood or hang in a small wire basket. 25 and 50 cts.

T. UTRICULATA. The Iargest native species. Leaves an inch or two in width, and 2 feet or more in length in fullgrown plants. Stems very tall, 3 to 5 feet, branched and many-flowered, but not so showy as $T$. fasciculata. A very rapid grower. Is easily established on a piece of wood, bark, or in a wire basket. Fine plants, 25 and $50 \mathrm{cts}$.

\section{Ferns and Selaginellas}

$\mathrm{T}$

HE USE OF FERNS in securing landscape effects is limited to certain special conditions. As a rule we do not recommend them for house borders where they are out of sympathy with thcir surroundings-though when so used on the cool, shady sides of the building, they can be interplanted with Sago PaIms, Dracænas, and plants of like character to good effect. However, they can be much more effectively used as ground. cover in low, damp woods, along little streamlets, and so on, where they appear to good advantage and in their proper setting. The drooping Nephrolepis, and Polypodium can be used to telling effect by planting in the boots of tall paIms, where they will flourish.

For deeorative use, they are being used more and more for special purposes as greenhousc or home specimens in tubs, in fern-dishes on the table, and are especially desirable in window- and porch-boxes where they can be used with telling effect. In house culture, they should be given some sunlight because the diffused lighting inside is so weak that the fronds are likely to be thin and drawn. The soil used should be generally rather light with leafmold or very old, rotted manure. Too much manure or concentrated fertilizer is injurious, though some sorts will be benefited with considerable added as top dressing. Wooden tubs, if not too large for the specimens, are always mueh superior to earthen pots or other receptaeles.

Special Notice.-Ncarly all arc pot-grown, so may be shipped at any time of the year.

Varieties with the asterisk $\left(^{*}\right)$ are the more hardy sorts. Others should be kept from hard frosts, being tropieal. Our list embraces a very choicc collection and will be found quitc complete.

ADIANTUM FARLEYENSE GLORIOSA. Glory very much like the old type, but comes from spores, and is a very valuable acquisition. The fronds are heavy with broad pinnæ, exceedingly graceful, and the plant attains large size under very ordinary culture and conditions. $50 \mathrm{cts}$.

A. HYBRIDUM. A very beautiful "Maidenhair" of exceptionaliy easy growth in pots or boxes. Small pinnæ, and long fronds. $50 \mathrm{cts}$, each; specimens, $\$ 1.50$ and $\$ 2$ each.

A. LUNULATUM. A "Walking Fern," rooting at the tips of plant; fine for baskets. 35 cts.

A. O'BRIENII. Very much resembling $A$. bybridum, with somewhat larger pinnæ and more fronds. Well adapted to Florida. $50 \mathrm{cts}$. and \$2. BLECHNUM SERRULATUM. * This well in large ferneries. Grows from 2 to 6 feet high. 25 cts. each, $\$ 2$ for 10 ; heavier, 35 cts.

CERATOPTERIS TARTAREA. Silver vigorous, with white powder on under surface of the fronds. Needs plenty of light and heat. 25 cts. each, $\$ 2$ for 10 ; heavier, 35 cts. each, $\$ 3$ for 10 .

CIBOTIUM BAROMETZ. This belongs to trunk. The broad, elegant fronds are lace-like with a delightful fragrance at times. Of quick and easy growth, this is a very popular house plant. Strong, 35 cts. each, $\$ 3$ for 10 ; heavier, 50 cts. and $\$ 1$.

C. SCHIEDEI. Tree Fern. A very imposing Fern of rare beauty, and with a hardy constitution, so that it may be easily handled. Difficult of propagation, it will never be common. Fronds broad, of a drooping nature, so that the plant shows best when standing on a pedestal when in a young state before the trunk is of appreciable size. $\$ 2$.

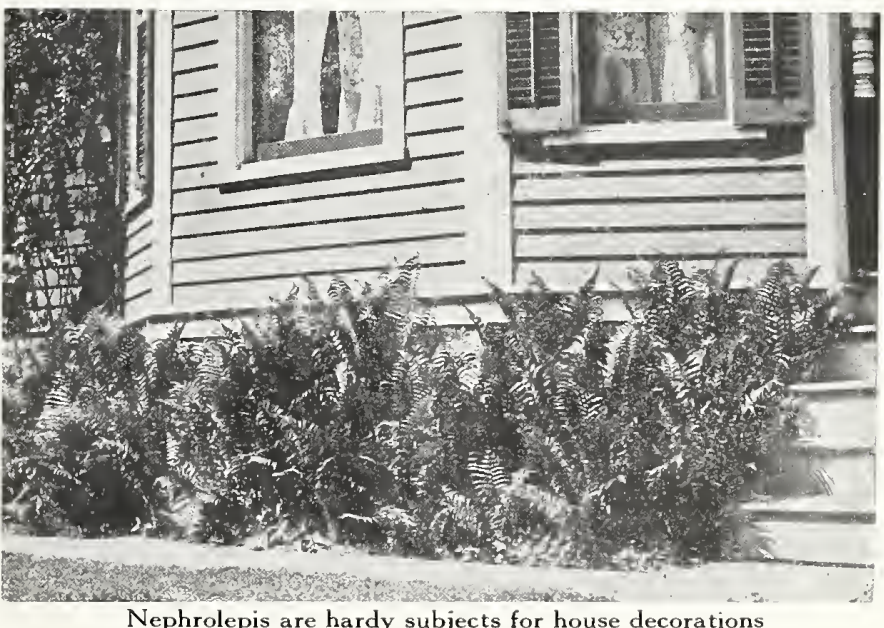

Nephrolepis are hardy subjects for house decorations 
FERNS AND SELAGINELLAS, eontinued

LOMARIA ciliatA. A baby Tree Fern, with

L YGODIUM SCANDENS. Japanese Climbing Fern. happens to be a true Fern. Grows up vigorously to a height of 10 to 15 feet, and makes a mass of the most charming lacelike growth, admirable as a specimen plant, or when cut for decorations. Very useful to the florist. $25 \mathrm{cts}$. each, $\$ 2$ for 10.

NEPHROLEPIS. Sword Fern. The various the best known house Ferns, growing under adverse condithe bell and giving satisfaction to all. They are without doubt the most popular Ferns for the living-room and busidoubt the most popular Ferns for the living-room and busiare grown in pots on pedestals, or in hanging-baskets, thus showing off their wonderful plumy fronds to best advantage.

N. BOSTONIENSIS. Boston Fern. Widely grown and a general favorite. A grand plant for general decorative use, always fine and beautiful. 35 and $50 \mathrm{cts}$.

N. CORDATA COMPACTA. Stocky and dwarf, with beautiful dark green leaves; a splendid plant, which should be freely used. Fine plants, 25 and $35 \mathrm{cts}$.

N. CORDIFOLIA. Something like the preceding, but with longer fronds not usually so dark green, and growing up to 2 feet high. A fine species of easy growth for baskets. 25, 35, and $50 \mathrm{cts}$.

N. DAVAllioides FURCANS. Stag-Horn Boston Fern. A grand decorative plant, with the ends of the fronds and pinnæ curiously divided and crestcd. A magnificent subject for a jardiniere, growing up to 4 feet high and 6 fect across. Nice stock, 35,50 , and 75 cts.

N. DUFFII. A very distinct Fern, with exceedingly narrow fronds, having divided tips something like those of the preceding. Grows up to about 18 inches high. $35 \mathrm{cts}$. each, $\$ 3$ for 10 .

N., JOHN WANAMAKER. A rapid-growing sort, with Iong, narrow, gracefully drooping fronds. Distinct, 35 and $50 \mathrm{cts}$

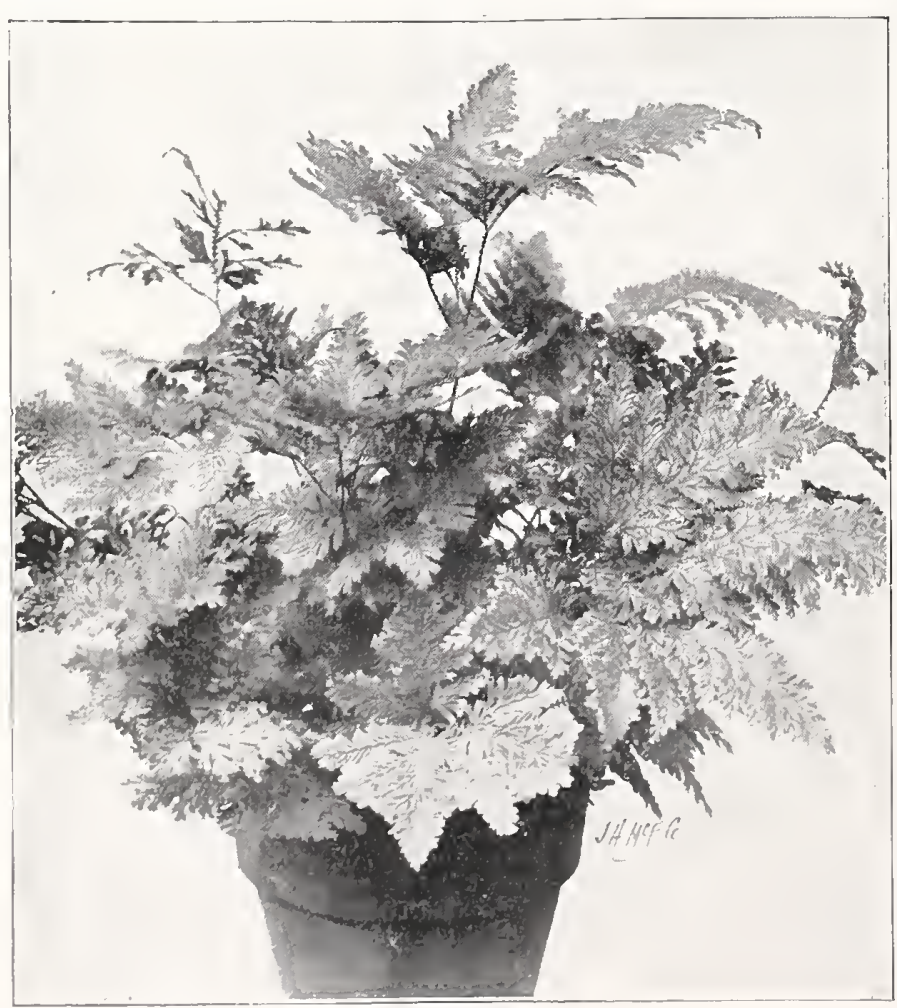

Selaginella
N. EXALTATA. Sword Fern. Tropics. Grows all round the earth. 25 cts. each, $\$ 2$ for 10 .

N., ROOSEVELT. Resembles the Boston Fern, but has more fronds, is bushier and handsomer, and the pinnæ are bcautifully undulated, giving the entire plant a lovely waving effect. 35 cts.

N. SCOTTII. Scott's Compact Boston Fern. A good form of the Sword Fern with broader fronds and a greater number per plant than the common sort; semi-dwarf. A very fine Fern. Strong, beautiful plants, 35 and $50 \mathrm{cts}$.

N., THE VICTORY FERN. A beautiful, new, crested form of Teddy, Jr. $50 \mathrm{cts}$.

N. WASHINGTONIENSIS. The largest growing of the Nephrolepis, and distinctive and distinguished in its appearance. Gigantic fronds are erect in habit, with long, wavymargined pinnæ. Very striking. Strong plants, $75 \mathrm{cts}$.

OSMUNDA CINNAMOMEA. Cinnamon Fern. * A hardy native Fern of very large size-

3 to 5 feet-with fronds bearing spores, coming up in the spring without any green foliage. $35 \mathrm{cts}$.

O. REgALIS. The Royal Osmunda. * This has very fine foliage, and divisions growing up to 6 feet. $35 \mathrm{cts}$.

POLYPODIUM AUREUM. Golden Polypody. grows in fibre of palmetto trecs. Distinct, $25 \mathrm{cts}$.

P. POLYPODIOIDES (incanum). Resurrection Fern. * Small plant with short fronds 6 inches long, growing freely on rough-barked trees in Florida; in moist weather they uncurl and grow. $15 \mathrm{cts}$.

POLYSTICHUM C OR I A CEU M . Leather-leaf Fern. Very attractive, large fronds of deep green color which keep well when cut; now largely used by florists. Makes a handsome specimen up to 2 feet in height. $50 \mathrm{cts}$.

P. FALCATUM (Cyrtomium falcatum). Holly Fern. This has dark green, very broad pinnæe and makes a very fine specimen up to 18 inches high. 35 and $50 \mathrm{cts}$.

P. LOBATUM. Excellent for window-boxes and table decorations. $25 \mathrm{cts}$.

PTERIS ARGYRÆA. Rather coarse, silvery height. $50 \mathrm{cts}$.

P. CRETICA. Low-growing; dark green; this and following three species are fine for windowboxes. 35 and $50 \mathrm{cts}$

P. CRETICA ALBO-LINEATA. A small plant not over a foot high, with fronds variegated white. $35 \mathrm{c}$.

P. TREMULA. Rather a large grower, 18 to 24 inches in height, dark green and attractive. 35 and 50 cts.

P. TRIPARTITA. A very strong grower reaching a heiolyt of 5 feet with good care. Striking and beautiful. 50 cts.

P. VICTORI $\approx$. Also a small, narrow-fronded species, variegated with white. $35 \mathrm{cts}$.

SELAGINELLA. Club Moss. Very ELAGINELLA. delicatc, fern-like light. Fine for Wardian cases.

S. BRAUNII. Erect species with curving fronds a foot long. Very beautiful and interesting. $25 \mathrm{cts}$.

S. CUSPIDATA. A dwarf tufterl plant. 25 cts.

S. HÆMATODES. One of the finest, from Gualemala, with large, spreading, fern-likc branches. Grows 10 inches tall. $50 \mathrm{cts}$.

S. UNCINATA. Rainbow Moss. A crecping S. U N flat, the fronds showing peacockblue and bronze tints. Fine for edging, or tubs, baskets, and the like. $25 \mathrm{cts}$.

S. VOGELII. A fine, erect species, with leaves from 1 to 2 fcet high, and showing bronze coloration at times. 35 cts.

S. WILLDENOVII. A giant creeping species, with clegant fronds of a pleasing shade of peacockblue and green, bronze, and the like. $35 \mathrm{cts}$. 


\section{ROYAL PALM NURSERIES}

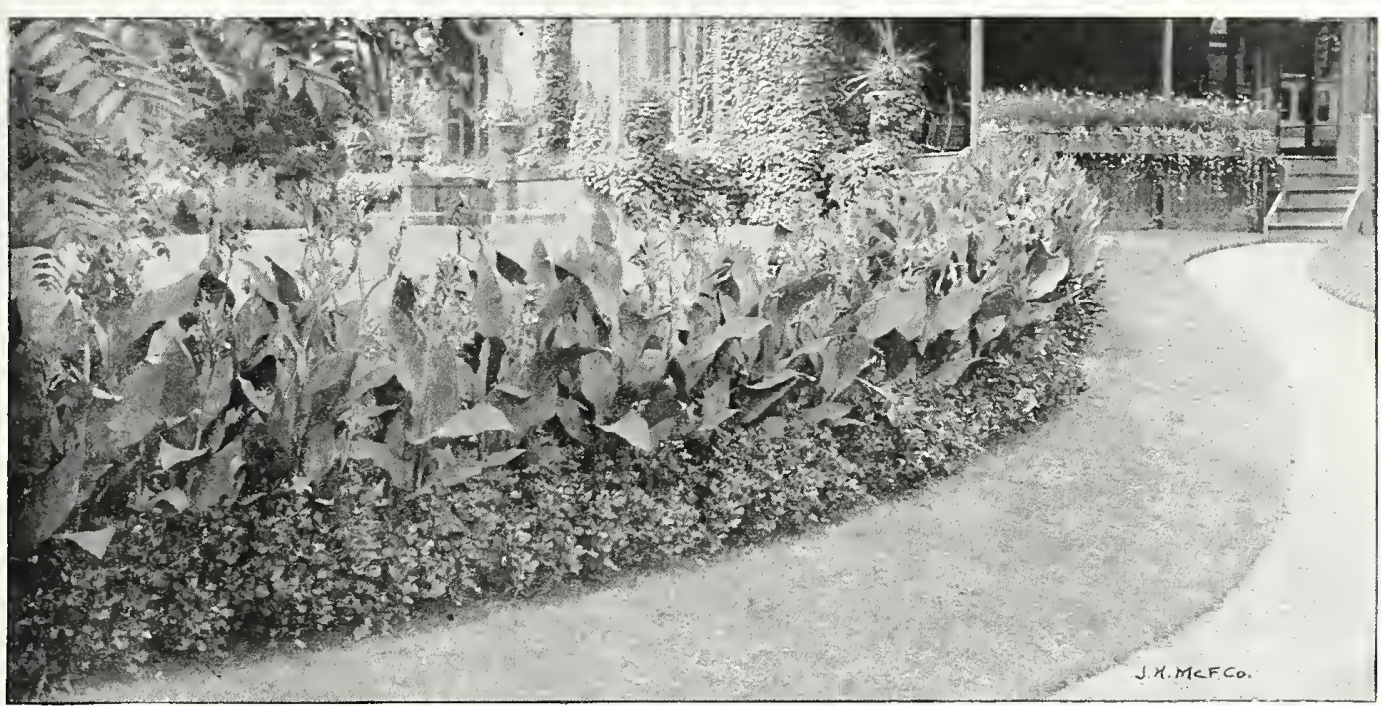

Canna border along path

\section{Tuberous, Bulbous, and Herbaceous Plants}

$\mathrm{N}$

O DOUBT the reason for the limited use of this class of plants is that its best use in securing landscape effects is so little understood and appreciated. Where the preparation of the soil has been adequate and the sicuation determined with careful thought and precision, nothing can be more showy, effective, and, withal, satisfying, than the Hippeastrums, Crinums, Moræa and the rest of the long line in their proper environment. These flowering subjects should not be planted as isolated specimens or Iong, thin lines detached from any supporting lines or masses, as we so frequently see them, but should rather be mixed in the borders with Iow-growing shrubbery. Here they can throw out their blossom spikes and be assured of a strong support of green foliage, and when the blossoms are faded and gone, there is still the border.

Special Notice. The best time to set this stock is in winter or early spring, although it would not be fatal to transplant at any time of the ycar, except in a very few instances.

Explanation of the Starring System: * Hardy as far north as the Ohio River (or farther) in the open ground. ** Those of a semi-tropical nature, standing sharp frosts without serious damage. *** Those of a tropical nature, useful in frostless regions or for bedding out during summer at the North.

\section{Group I. Flowering Lily-like Species}

CALLA DEVONIENSIS. Godfrey Calla. A decided improvement over the old-fashioned Calla. A good grower with large flowers of purest white. More floriferous than the old variety and not such a tall grower. Prefers a rich, mucky soil. 50 cts. each, $\$ 4$ for 10.

CANNAS. ** These splendid broad-leaved plants secure used very widely in the North fo better advantage here in the South. While they can be planted on almost any class of soil, they prefer a heavier one with a fairly constant water-supply. For this reason, they have proven especially useful in planting around the margins of lakes and along streams where they grow and flourish to perfection. With this they should have plenty of sunshine. After flowering, each matured stalk should be cut out to allow the young suckers to come into blosson.

PRICES: Austria, Italia, and Indiana, $20 \mathrm{cts}$. each, $\$ 1.50$ for $10, \$ 10$ per 100 . All others named, $25 \mathrm{cts}$. each, $\$ 2$ for 10

AUSTRIA. Soft, chrome-vellow; height, 4 to 5 feet.

DRAGON. Dark ox-blood red; leaves green; height, 3 to 4 feet.

FIREBIRD. Glowing scarlet, leaves green; height, 4 to $5 \mathrm{ft}$.

GAIETY. Vermilion and gold; leaves green; height, 3 to 4 feet.

INDIANA. Rich orange; leaves green; height, 5 to 6 feet.

ITALIA. Golden yellow, blotched orange; leaves green; height, 3 to 4 feet.
KING HUMBERT. Glowing orange-red, with bronze leaves; height, 4 to 5 feet.

MRS. A. F. CONARD. Soft rose-pink; leaves green; height, 3 to 5 feet.

UNCLE SAM. Strong, frery red; leaves green; height,

5 to 6 feet.

WYOMING. Beautiful orange color; leaves bronze, or purple; height, 5 to 6 feet.

CANNA FLACCIDA. Orchid Canna. Native. Dwarf habit, with clear.yellow flower 3 to 5 inches across. Light green leaves. Height, 2 to 3 feet. $15 \mathrm{cts}$. each, $\$ 1$ for 10.

CRINUM. ** These magnificent flowering bulbs are cratium. Evergreen, of easy culture in Florida in the open ground; in the North in the greenhouse.

C. AMERICANUM. Native. A most beautiful plant producing umbels of large, white, Iilv-like flowers often six or eight to the spike. A native of the Florida swamps, but, like most of the Crinums, not particular as to soil or situation. 25 cts. each, $\$ 2$ for 10 .

C., EMPRESS OF INDIA. Large plant, producing freely in sumnier, umbels of drooping flowers, deep rose-color, striped very pale flesh-pink. $50 \mathrm{cts}$.

C. FIMBRIATULUM. Nassau or Milk and Wine Lily. Guiana. A strong grower, not particular as to soil. Flowers in umbels, large and showy; striped white and carmine; 3 to 4 inches in diameter. 15 and 35 cts. each. 


\section{FLOWERING LILY-LIKE SPECIES, continued}

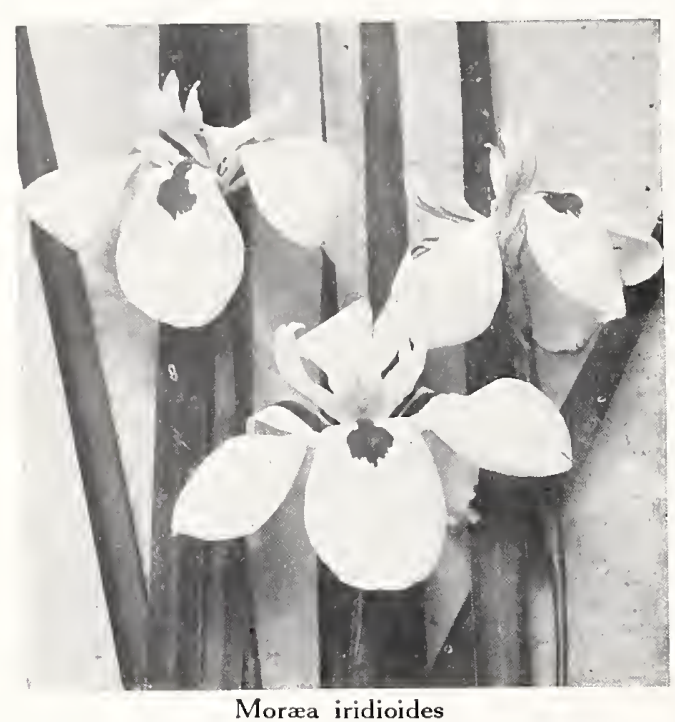

CRINUM GIGANTEUM. Tropical Africa. Foliage very large, broad in the center, narrowing at both ends. Flower bell-shaped, purc white, highly scented. Needs half shade and moisture. $\$ 2$.

C. KIRKII. East Africa. The flowers are Iarge, white, with a reddish purple stripe on the outside of each petal which, showing through, gives the flower a pink tinge on the inside; some ten or fifteen of these flowers an produced at the top of a tall purple spike, and there are frequently two or more spikes of bloom from the bulb during the season. 35 and $50 \mathrm{cts}$.

C. KUNTHIANUM. Vigorous-growing and abundant bloomer from New Granada. This is a grand species, with splendid flowers, dull white, tinged with rose-red. $25 \mathrm{c}$. and $50 \mathrm{c}$.

C. VIRGINICUM. A choice hybrid originated in England; flowers very large and widely opened, white and rosy pink. 25 and 50 cts.

CURCUMA PETIOLATA. Queen Lily. ** India. canna, but strongly veined and arched. Flowers in short, torch-like bunches among the leaves, white, tinted pink, which last for wceks. 25 cts. each, $\$ 2$ for 10 .

GLORIOSAS. Climbing Lilies. These gorgeous lilyon fences, Iatticc, or similar support, so we classify them properly with the vines, which see, page 36.

HEDYCHIUM CORONARIUM. Ginger Lily; Butplant flourishes best on low, moist land, where it will form a dense clump 3 to 6 fcet high. The roots are tuberous, and the plant may be safely grown over the entire South. The masses of fragrant, pure white flowers, looking much like large white butterflies, are borne in large clusters, terminal on every stalk, blooming all summer and fall. $25 \mathrm{cts}$. each, $\$ 2$ for 10 .

HEMEROCALLIS. Yellow Day Lily. * Old and beloved of our grandmothers. are splendid subjeets for Florida and the South generally. We have three distinct sorts as follows, in fine, large sizes, at $25 \mathrm{cts}$. each, $\$ 2$ for 10 .

H. THUNBERGII. Yellow Day Lily. * Europe and Asia. Flowers are about 3 inches across, clear yellow, and borne on long stems. Very beautiful.

H. FULVA. * Europe and Asia. The single form of the Tawny Day Lily. See the following:

H. FULVA FL.-PL. * Europe and Asia. The doubleflowered form of the Tawny Day Lily. Flowers bright orangeyellow, very freely borne in early summer. This is a valuable hardy border plant; will grow anywhere.

\section{HIPPEASTRUM EQUESTRE. Amaryllis or Bar-} ica. These glorious, large, bright red, spring-flowering subjects are now commonly grown throughout the South, and masses of them should be in every garden. They are particularly useful for scattering in groups throughout the border plantings, naturalizing in the woods and along lakes and streams. They are of easy growth and spread freely, and in Florida fill the niche of the tulips of the North. $15 \mathrm{cts}$. each, $\$ 1$ for 10 .

H. HYBRIDA. Hybrid Amaryllis. ** Hybrids of the choicest sorts procurable, through work of two of our most eminent Florida horticulturists and hybridizers. Flowers are large to very large, mixed colors, mostly scarlet, but with wondcrful markings and stripes of pink or white, and the like, and many of them delightfully scented. They bloom in spring and are cxceedingly showy and attractive. Bulbs whieh should bloom next spring, 35 cts, each, $\$ 3$ for 10 .

HYMENOCALLIS CARIB EA. (Pancratium

Spanish Lily. ** West Indies. A bulb of easiest culture, producing large clusters, a tew plants giving a succession of bloom all summer. Color, pure white. Strong bulbs, 15 cts. each, $\$ 1.25$ for 10 ; extra-heavy, $25 \mathrm{cts}$. each.

IRIS HEXAGONA. Blue Flag. * Native. Evergreen. A hardy southern variety of the greatest possible

beauty. The loveliest flower of the whole South. Rich purple and blue with yellow markings: 3 to 4 inches across; resembles the costliest and rarest orchid flower. Blooms in spring. $15 \mathrm{cts}$. each, $\$ 1$ for 10 .

MORAEA IRIDIOIDES. Natal Lily. ** South AfORAEA rica. A lovely iris-like plant, to which it is closely related, with numcrous fan-shaped clusters of flat, tapering, ribbon-like leaves and spikes of flowers 3 inches across, white, marked yellow on claws of outer segments and style crests marked with blue. This succeeds here to perfection and is without a peer as a border plant in Florida. $35 \mathrm{cts}$. each, $\$ 3$ for 10 .

\section{Group II. Of Chief Value for Foliage Effect}

These speeies do partieularly well in a rather moist soil, particularly the Aloeasias, Colocasias, Caladiums, Xanthosomas, and the like, and are espeeially happy and contented on the margins of streams and ponds where they make enormous masses of foliage, elassie in design and invaluable for the striking effect they ereate in the garden pieture.

ALOCASIA MACRORHIZA. *** Ceylon. This ALOCASIA group includes the most classic-looking plants of the Caladium-like type, and we especially recommend them for securing tropical effects in patio and watergardens as well as in the semi-formal gardens. $35 \mathrm{cts}$

A. INDICA (A. plumbea), **** Borneo. This is a particuIarly fine subject for usc in vases, with its stiff, arrow-like leaves of deep reddisl purple and lead-green color. $50 \mathrm{cts}$.

See Xanthosoma and Colocasia in this Group for allied plants.

AMOMUM CARDAMOMUM. Cardamon Plant. *** This plant is decorative for its foliage only, but of particular interest in the thick, leathery leaves which, when crushed in the hand, give out a strong, delightfully "gingery" odor. Does especially well when supplied with considerable moisture, but will grow nicely on any good soil. 35 cts.

BR YOPHYLLUM PINNATUM. ** An odd and rapid-growing succulent.

Flowers green and rcddish bronze, in form of bladders. One of those strange plants that are propagated from leaves. Extrcmely curious. The leaves may be pinned on the wall and will throw out sprouts from every notch without watering. Naturalizes itself nicely on any favorable location, liking particularly one that is part sun and part shade. $15 \mathrm{cts}$. each, $\$ 1$ for 10 . 


\section{ROYAL PALM NURSERIES}

CALADIUMS, FANCY. *** Splendid ornamental winter. Leaves arrow-shaped, marked with the brightest colors-red, green, yellow, purplish, and sometimes almost a transparent white. No other plant possesses more richness or delicacy in coloring. Prefers a moist and half-shaded place with rich soil. They are grand house plants and fine for window-boxes, etc. Our collection is one of the finest in this country.

Mixed Sorts, 25 cts. each, $\$ 2$ for 10.

BEST NAMED SORTS. $50 \mathrm{cts}$. each, $\$ 4.50$ for 10.

COLOCASIA ANTIQUORUM ILLUSTRIS. ** Inxanthosoma. This grows from 18 inches to 3 feet high. Leaves heavily blotched with velvety black. A splendid plant and fine for massing. $25 \mathrm{cts}$. each, $\$ 2$ for 10 .

C. ESCULENTA. (Caladium esculentum.) Elephant's Ear. ** The well-known showy, green-leaved summer bedding plant. Enormous-sized leaves; plant growing up to 7 or 8 feet. 25 cts. each, $\$ 2$ for 10 .

C. SPECIES. Dasheen. ** A splendid starchy food-plant, resembling potatoes and now grown generally in Florida for the markets. 15 cts. each, $\$ 1$ for 10 .

HELICONIA BIHAI. Wild Plantain or Balisier. *** ing ing to a height of 10 to 15 feet, resembling a musa (banana).
Green foliage, purplish stems, yellow flower spikes. $75 \mathrm{cts}$.

MARANTA ARUNDINACEA VARIEGATA. Comgatum. A plant with canna-like foliage growing to a height of 3 feet, beautifully variegated with white. $25 \mathrm{cts}$. each, $\$ 2$ for 10 .

PIAROPUS CRASSIPES. The famous Water HyaIAROPUS cinth. A beautiful floating plant with bright flowers in spikes, lilac, blue and yellow: 2 inches across. Will grow in clear water in the house admirably. A valuable forage plant for cattle; will grow in ponds and streams all along the Gulf Coast. Special prices for large quantities. $15 \mathrm{cts}$. each, $\$ 1$ for 10.
RENEALMIA SPECIES. Porto Rico. Related to let bracts which remain on indefinitely. 25c. each, $\$ 2$ for 10 . SANSEVIERIA GUINEENSIS. African BowAtring Hemp. A quick-growing shaped this and following species are undoubtedly the toughest plants known that may be used as decorative subjects. They live in water, or dry soil, for weeks, and in dark rooms for months without attention. Strong plants, 15 cts. each, $\$ 1.25$ for 10 ; larger, 25 cts. each, $\$ 2$ for 10 .

S. ZEYLANICA. Ceylon Bow-String Hemp. As a fiberplant this has been prized from remote antiquity. A finer decorative plant even than $S$. guineensis, at 15 and $25 \mathrm{cts}$. THALIA DIVARICATA. A magnificent native, orna-

the North as easily as a canna. The enormous leaves, with red midribs, resemble the banana, and are 2 to 4 feet long. Flowers purplish, borne on stems 6 to 10 feet tall. $25 \mathrm{cts}$. each, $\$ 1.50$ for 10 .

XANTHOSOMA BATAVIENSIS. ** Le a ves ANTHOSOMA rather long and arrow-shaped, dark green, with veins and ribs showing purple on under surfaces; stems also purple. This like all the following species are wonderful bedding and border plants for rich soil. $35 \mathrm{cts}$.

X. MARSHALLI. ** Very quick-growing, of medium size. Green leaves and dark stems; an especially good bedder for all parts of the states having warm summers. Quite different from the common "Elephant Ears" so of ten seen, and being of easy growth can not fail to give satisfaction. Strong tubers, $15 \mathrm{cts}$. each, $\$ 1$ for 10 .

X. SAGITTIFOLIUM. ** Leaves large, pale green. Tubers sometimes used as food. A strong grower of great possibilities in bedding and border planting on rich soil. $25 \mathrm{cts}$. each, $\$ 2$ for 10 .

X., SPECIES UNKNOWN. ** Leaves very light green, moderate sized. $15 \mathrm{cts}$. each, $\$ 1$ for 10

X. VIOLACEUM. ** A grand species, of large size, with deep, bluish-green foliage and very dark stems. A superb decorative subject; evergreen habit. $25 \mathrm{cts}$. each, $\$ 2$ for 10; extra-sized, 35 cts. each.

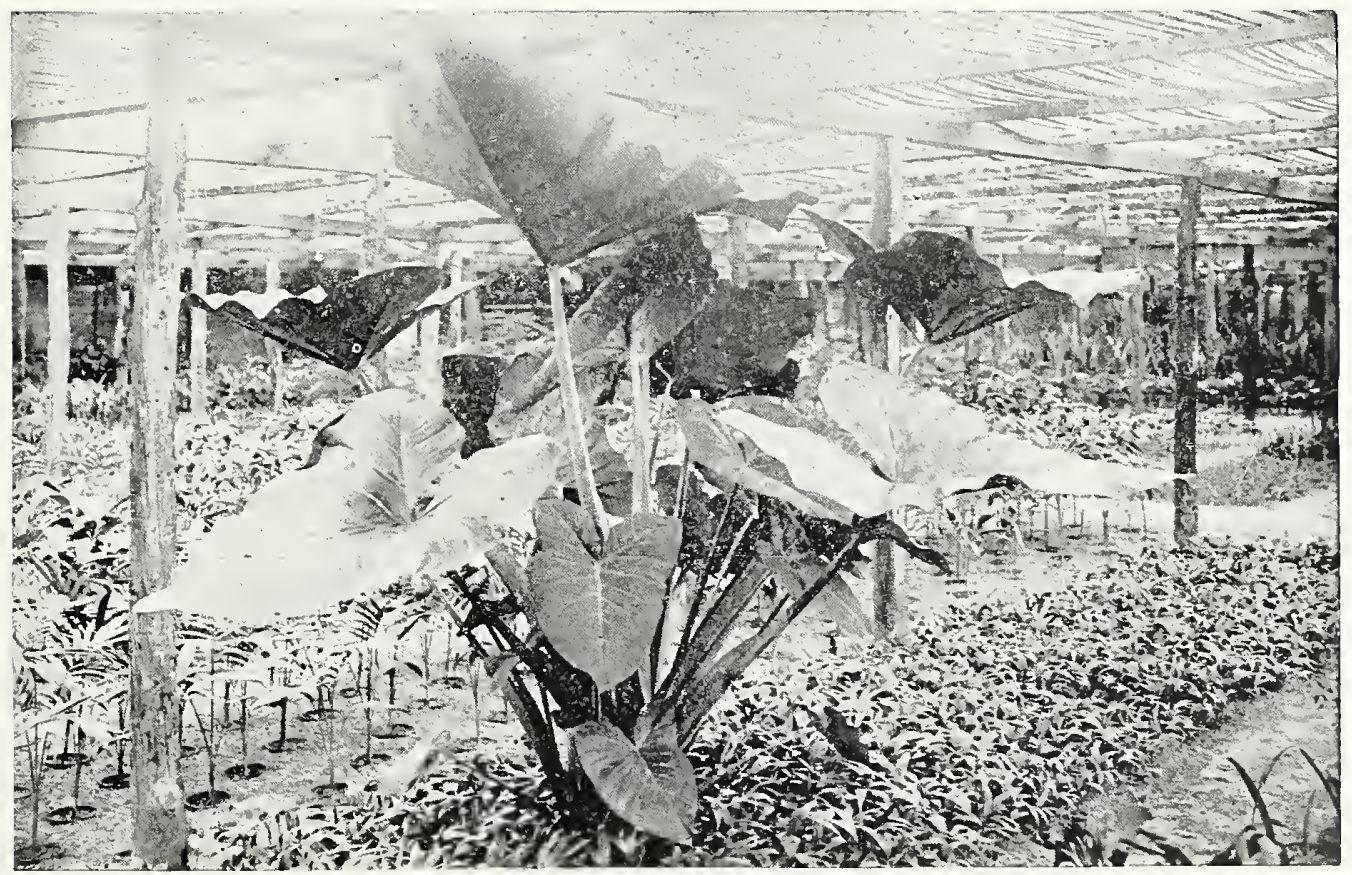

The classic Xanthosoma 

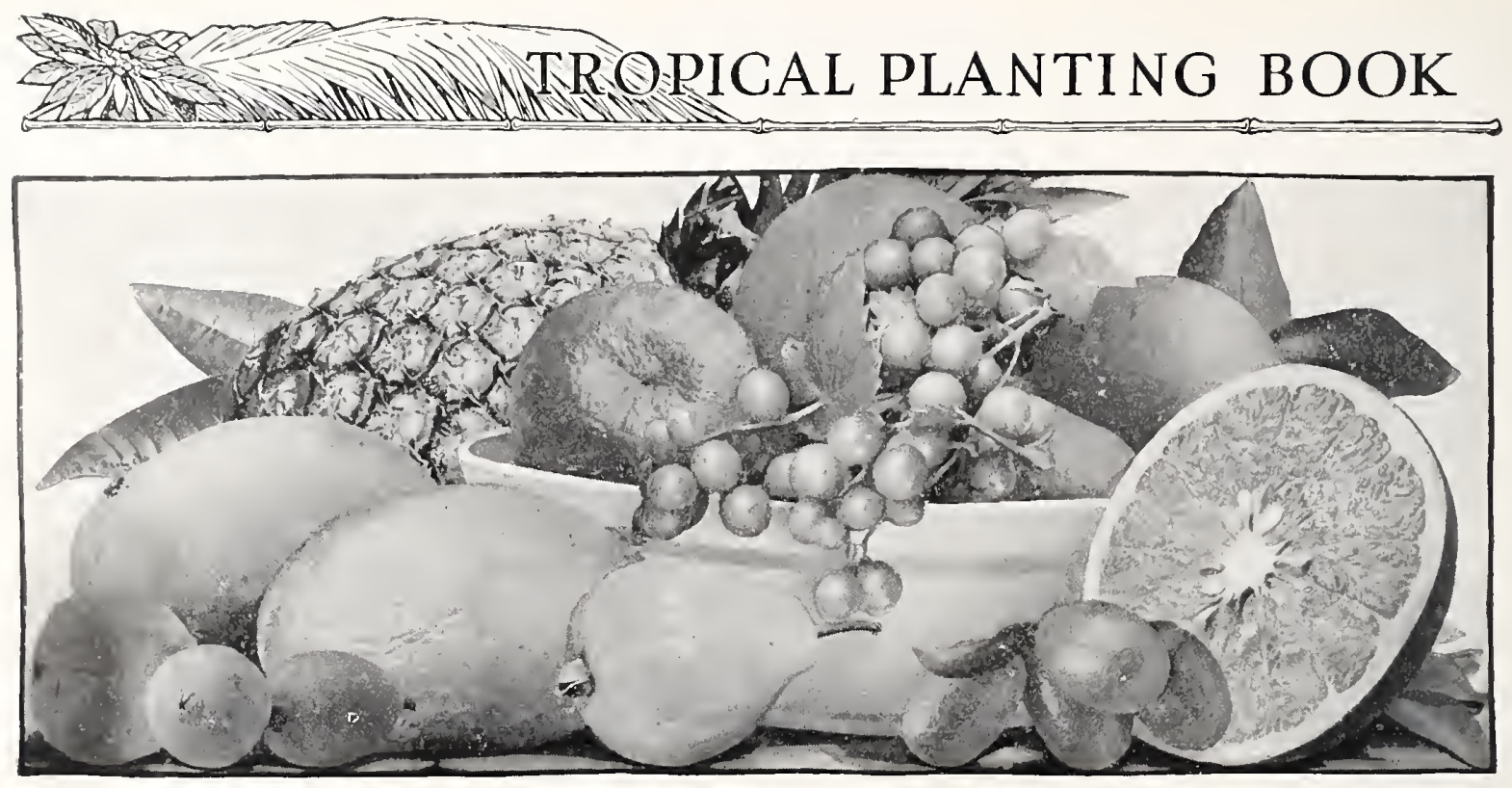

\section{Fruit Trees and Plants}

$\mathrm{T}$

HE GENERAL CULTURE of fruit trees and plants is not essentially different from that of other subjects; a modicum of common sense with a little experience and knowledge gleaned through study is worth more than some of the advice your neighbors will give. Not but that their advice may be good so far as it goes in many cases-but ten to one they will either give different or varying opinions, or all agree on the wrong idea. That which you Icarn for yourself you learn well, and will probably fit your case better. Of course, there are special considerations with certain subjects like Avocados, Mangos, Citrus Trees, and the like, and yet after all, it is a littlc odd how many instances there are of bcliefs of a few years ago that were thought as unchangeable as the universe upon which we now look back and wonder how we could have believed them at all.

While the growing of the more tropical varieties of fruits is not to be generally recommendcd except in the most protected scctions and spots of the state as a commcrcial proposition, we would call your attention to the fact that there are a numbcr of such subjects that even when frozen down will throw up strong shoots that bear again aftcr a reasonable time. For that reason they should receive consideration in much of peninsular Florida, even above the mythical "frost-line." Among them we would include the Guavas, Surinam Cherry, Pineapples, and Papaws.

Explanations of Symbols. T., tropical sorts, adapted only to extreme South Florida planting out of doors, or to plant-sheds where they can receive adequate protection, or to the conservatories of the North. ST., semitropical sorts adapted gencrally to peninsular Florida wherc, even if frozen back more or less, they come right out and flower and fruit with little sctback. H., hardy subjects for general planting over Florida and the Gulf Coast. AII tropical stock does best when set in warmer weather. Of the hardier $(\mathbf{H})$ subjects, those marked with "W" should be set only during the period of Dccomber to February, with Dccember much to be prefcrred. Those markcd $\mathbf{P}$ are pot-grown-others grown in open ground.

\section{Group I. Tree Fruits}

ACHRAS SAPOTA. Sapodilla. T. Evergreen 1 ree bearing russet fruits with thin, shell-like skin and containing juicy and most luscious pulp. As it stands even actual inundations of salt water, it is to be especially recommended for seashore planting in South Florida. See, also, Tree Department, page 15 . Nice small stock, all pot-grown plants, $25 \mathrm{cts}$. each, $\$ 2$ for 10 ; larger, $50 \mathrm{cts}$. each, $\$ 4.50$ for 10 .

AMYGDALUS PERSICA. Peach. HW. A deof clistinctive flavor, particularly tree bearing delicious fruits much earlier than the northern Peaches. We offer only a selected list of choice varieties which, when grafted on plum stock, are free from root-knot. They should be planted only on well-drained land; in fact, after once established, they will succeed well on high, dry ridges where many other fruits fail. Set deep so that graft union is several inches under the soil.
PRICES ON PEACH TREES.-ON Plum Stock, 3 to $4 \mathrm{feet}$ high $50 \mathrm{cts}$. each, $\$ 4.50$ for $10 ; 4$ to 5 feet high, $65 \mathrm{cts}$. each, $\$ 5.75$ for 10 . On Peach Stock, 3 to 4 feet high, 40 cts. each, $\$ 3.50$ for 10 .

ANGEL. Of good size, with yellow skin, washed with red. Flesh white. Freestone. Ripens in June.

HALL'S YELLOW. A late-ripening freestone, maturing in late June or early July. The fruit is Iarge; skin yellow, washed with red; flesh yellow and red at stone. Quality fine.

JEWELL. The earliest and best market Peach for South Florida planters. Is of medium size, high color, fine quality and freestone. Ripens in May.

MIAMI. Large, creamy yellow; ripens in May about same time as Jewell.

RED CEYLON. Very productive, freestone, ripening in May or later, of mediun size and special value for cooking. This last can be furnished on plum stock only. 


\section{ROYAL PALM NURSERIES}

CARYOPHYLLUS JAMBOS. Rose Apple. T. sized pinkish white, rose-scented and rose-flavored fruits, valuable for cooking and candying. P. Strong plants, $50 \mathrm{cts}$. eaeh, $\$ 4.50$ for 10 ; extra large, $\$ 1$ each, $\$ 9$ for 10 .

CECROPIA ADENOPHYLLA. T. A Government inplants, $50 \mathrm{cts}$. each, $\$ 4.50$ for 10.

C. INDICA. T. Resembles the following but a better grower. P. Strong plants, 35 cts. each, $\$ 3$ for 10 .

C. PALMATA. Shakewood Tree. T. Tall-growing tree with handsome palmate foliage. Fruit curiously like fingers, soft and sweet, resembling fig, and with minute secds. The flowers are diocious, so several of the trees should be planted to insure a bearing specimen. P. $25 \mathrm{cts}$. each, $\$ 2$ for 10 .

\section{Citrus Section}

Our nurseries for citrus stock are on high sandy soil, insuring good roots. This class of stock succeeds equally well on low or high lands when transplanted, but when set on low Iands the planter should make large mounds so that in wet seasons the crown-roots may be well out of standing water. On low lands, if there is hard-pan, the holes should be blasted by dynamite, and free use of lime or marl made; the tap-roots should be cut rather short also-say 9 to 12 inches.

PRICES ON CITRUS TREES.-For all varieties except those specially noted in descriptive text. Each 10 100

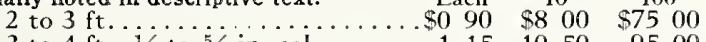

3 to $4 \mathrm{ft}$., $1 / 2$ to $5 / 8$-in. cal.......... $115 \quad 10 \quad 50 \quad 9500$

4 to $5 \mathrm{ft}$., $5 / 8$ to $3 / 4$-in. cal.......... $160 \quad 1450 \quad 12500$

5 to $6 \mathrm{ft}$., $3 / 4$ to $1-\mathrm{in}$. cal..........2 $2402100 \quad 19000$

Two-year, 1 to $11 / 4$-in. cal......... $3252650 \quad 24500$

GRAPEFRUIT or POMELO. (Citrus grandis.) ST.

FOSTER. The newest and most valuable of all Grapefruit, identical with the celebrated Wallers, from a tree of which it is a "sport," except in the color of flesh, which is described in the Government Pomological Notes as follows: "Next to the skin the flesh is a light purplish pink color, which shades to a clear translucent color at the core; there is very little pulp." Prof. Hume writes: "My opinion of the Foster Grapefruit is that it is a fine fruit. It is the best early Grapefruit that I know of. It was in good eating condition at Winter Haven earlier than any other variety we have tested, and I think we have them nearly all." On rough lemon and sour orange stock, in all sizes.

MARSH SEEDLESS. Medium to large size; almost or quite seedless; juice somewhat bitter. The fruit is late in ripening and holds exceptionally well without waste. Grown on sour orange stock, all sizes.

KUMQUAT (Citrus japonica). O B L ONG or dwarf tree; admir NAGAMI. ST. A small fruit and dwarf tree; admirable for small plots of ground or for con-
servatories. Fruit eaten either raw or cooked. Very ornamental. Prices on a special stock, particularly adapted, $1-y r ., \$ 1.50 ; 2-y r ., \$ 2$. (Trees are bushy and can not be graded with standard citrus trees.)

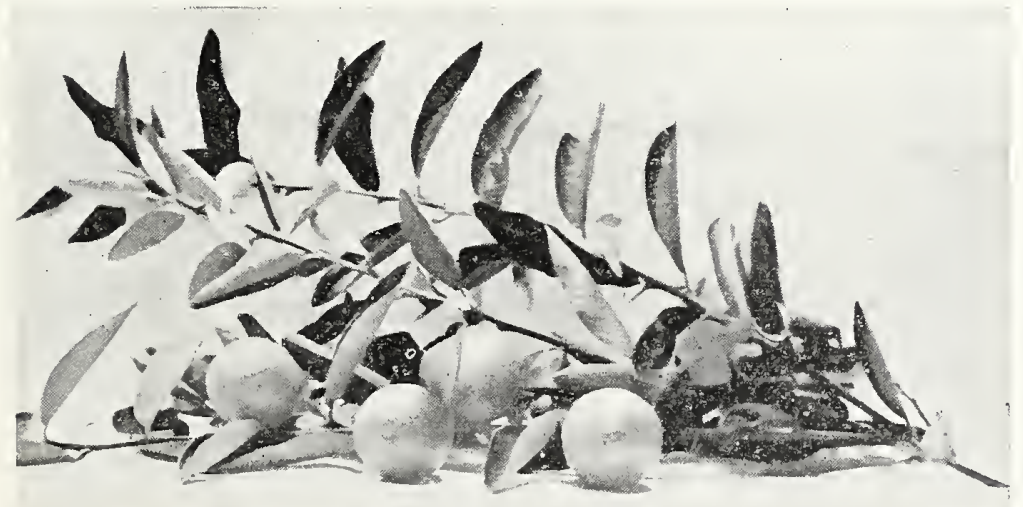

Eustis Limequat

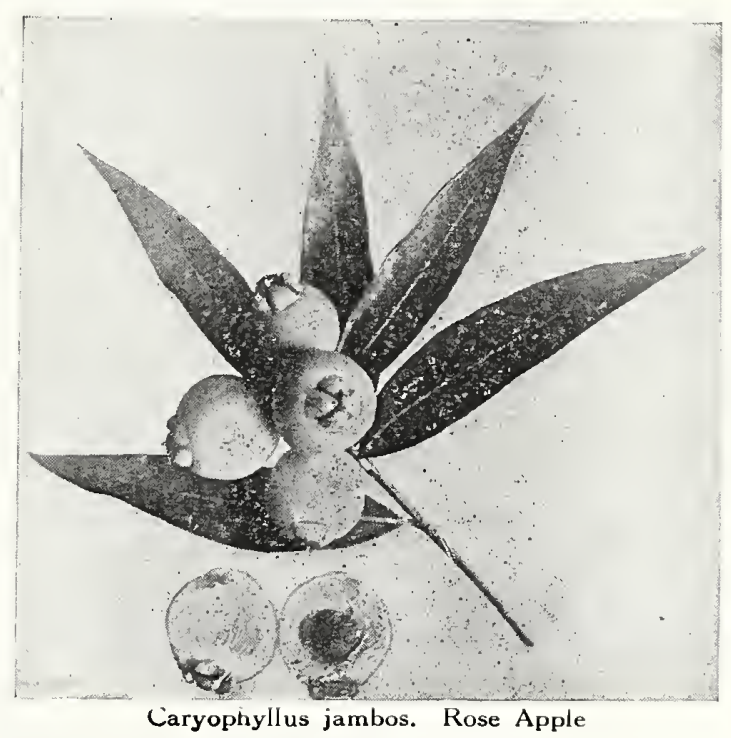

LEMON (Citrus limonia). DWARF CHINESE. ST. Valuable as a pot plant in the North, being very ornamental. In winter "a small plant often has a dozen large Lemons hanging on its branches," rather roundish in outline. This has proved spccially hardy in Florida and the fruit is available almost the entire year. Juice very acid and valuable. On sour orange stock, in the smaller grades.

LIME (Citrus aurantifolia). T. The Limes are generally more tender than other citrus trees, and should have
protection from cold in frosty locations. Limes have a very agreeable acid and as the fruit of several sorts ripens at intervals through the year, they are especially valuable for South Florida, both for home use and for market. Especially delightful when used on Avocados.

RANGPUR. One of our early Indian introductions. This has a loose rind somewhat like the mandarin and a rich reddish color of both skin and pulp of extra superior flavor and quality. Extra hardy. On sour orange stock, in the smaller grades.

LIMEQUAT, EUSTIS. A hybrid of the common partment of Agriculture. Tree is a good grower and bears two or three crops under good care per year. Fruit oblong, about size of limes, thin-skinned, acid, and may be used in place of limes or lemons. Verv bardy and may be grown aII over Florida. On sour orange stock in all smaller grades.

MANDARIN (Citrus deliciosa). ST. All in this wroup have usually flattened fruit, adherent, sometimes called "kid glove" Oranges. Prices as follows:

\begin{tabular}{llllll}
2 & \multicolumn{3}{c}{ Each } & 10 & 100 \\
2 to $3 \mathrm{ft} \ldots \ldots$ & $\$ 100$ & $\$ 900$ & $\$ 8000$ \\
3 to $4 \mathrm{ft} \ldots \ldots$ & 1 & 35 & 1200 & 11000 \\
4 to $5 \mathrm{ft} \ldots \ldots$ & 1 & 85 & 16 & 50 & 15000 \\
5 to $6 \mathrm{ft} \ldots \ldots$ & 2 & 75 & 2500 & 22500
\end{tabular}

DANCY (Tangerine). Fruit of delicious sparkling quality; midseason in ripening; skin orange-red, very highly colored. On sour orange and rough lemon stock, in smaller grades.

ONECO. Exceedingly rich quality, ripening in late January to March. Skin not so attractive as Dancy, but of good color; shape rather thicker and rounder than Dancy. On sour orange stock, in smaller grades.

KING. A very large Mandarin with peculiar rough skin, ripening from March to May. On sour orange stock, in smaller grades. 


\section{CITRUS SECTION OF TREE FRUITS, continued}

ORANGE (Citrus sinensis). ST. With the perfecting RANGE of the methods of handling fruit by the Florida Citrus Exchange, Orange-growing has taken on new life and prosperity, and bids fair to more than hold its own as a business for Florida. We offer only the cream of the inany kinds which all grow to perfection in Florida.

LUE GIM GONG. "A late round Orange of unusual merit," originating at DeLand, Florida. The fruit is of the very best quality, large size, good color, and holds on the tree well, all summer, like the Valencia. On sour orange stock only, small and medium grades.

PARSON BROWN. The best of the early Oranges grown on a commercial scale. The fruit is of mcdium to large size, excellent quality and ripens as early as last of October and November. Furnished on sour orange stock only, in all grades.

PINEAPPLE. A strong, upright grower and prolific bearer. Medium to large size fruit, thin, tough, very bright colored skin, juicy and of fine, distinctive flavor. On rough lemon stock, in all grades.

RUBY. A blood Orange of merit, ripening fairly early and in season until February. The "blood" coloration only occurs very late in the season. A very prolific bearer. On sour orange and rough lemon stock in all grades up to 5 to 6 feet.

SURPRISE NAVEL. The best of all navels so far tried in Florida. Season December to February. On rough lemon and sour orange stock in all grades.

VALENCIA LATE. Synonyms: Tardiff, Hart's Tardiff, Hart's Late, etc, Very late keeper, season being from March to July, or even Iater. A fine, heavy Orange of exceptional value. On rough lemon and sour orange stock in all grades.

TANGERINE. See Mandarin.

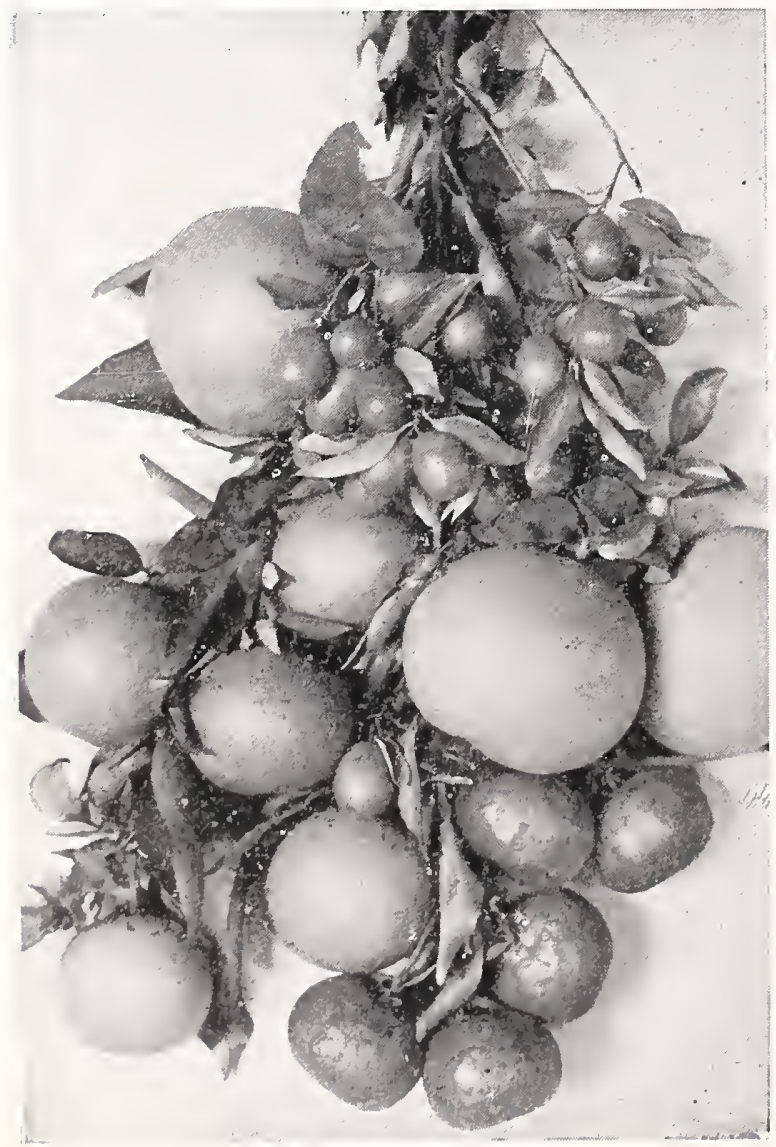

Assorted Citrus Fruits
TANGELO. ST. Of the many hybrids made in the this type from the Tangcrine and Pomelo is of grcat value and interest. From the various sorts produced, we like the Sampson so far the best, and have trees on sour orange stock 2 to 3,3 to 4 , and 4 to 5 feet in size, at regular prices of other citrus trees quoted.

CALAMONDIN (Citrus mitis). ST. A small citrus height, from the Philippines, proved quite hardy here, and exceedingly prolific, bearing one or more crops per year. The fruit is small, round, or oblate, about an inch thick (or like the lime), very acid, and fine for summer drinks, or for marmalade. Because of its resistancc to cold, it being one of the most hardy of the citrus fruits, it is especially valuable for growing on home places in connection with the hardier avocados, taking the place of the lime in sections wherc that fruit will not stand the winter temperatures. The avocado is especially delicious with the juice of the more acid citrus fruits. On Citrus trifoliata roots, strong plants, $\$ 1.50$ each.

COCCOLOBIS UVIFERA. Sea-grape. T. Beautiful evergreen tree with purplish

fruit borne in spires like currants, ripening in September, and from which a very fine jelly is made, of superior quality. See Tree Department, page 15. P. $25 \mathrm{cts}$. each, $\$ 2$ for 10 ; larger, 75 cts. each, $\$ 6.50$ for 10 .

DIOSPYROS KAKI. Japan Persimmon. HW. A

valuable fruit for the entire South even to southern Florida and since the discoveries regarding pollination of the flowers, far more desirable to plant both for home use and market. The Gailey variety was found to be constantly staminate in flower, so bears abundantly and furnishes pollen for surrounding trees. It should be in every collection of mixed planting, although the other varieties we offer bear well singly.

Prices on standard grade, 4- to 5-ft. trees, $65 \mathrm{cts}$. each, $\$ 6$ for 10

FUYUGAKI. A new variety of Persimmon of particular interest and merit, never being astringent, and can be peeled and eaten while still hard like an apple. Of medium size, slightly flattened and deep red color; it keeps well and promises to be the best of the commcrcial varieties.

GAILEY. Small, oblate-conical, dull red in color; flesh dark about the seeds, meaty, firm and juicy. A new introduction recommended for planting with other Persimmons, but fruit only fair in quality.

TAMOPAN. This is a grand acquisition, introduced from China. Fruit very large, up to one pound in weight, flattened, with constriction about the middle; color orange; fruit astringent until fully ripc; quality very fine. This is a vigorous grower of large size and should be freely planted.

TANE-NASHI. Large roundish, conical, about $31 / 4$ by $33 / 8$ inches in size; skin yellow, changing to bright red; flesh yellow, seedless, of best quality. Vigorous and prolific, bearing abundantly every season; this has proved the best of the older sorts for market.

TRIUMPH. Fruit rather small, tomato-shaped; skin deep red in color. Very productive, of good quality, ripening from September to Deccmber. This makcs a good-sized tree and succeeds in South Florida.

ERIOBOTRYA IAPONICA. Loquat; Medlar, or ERIOBOTRY A Japan Plum. HW. A most valuable winter and spring ripening fruit, yellow, size of plums, deliciously flavored, and fine for preserving. This should be grown extensively in Florida for both homc markets and for shipping. As the flowers are sometimes frost-bitten, grow in protected places, or fire during the time of the cold spells. The tree is evergrcen, with handsome large rough leaves, worthy of being grown simply as an ornamental both in pots and outdoors. Pot-grown common seedlings, 25 cts. each, $\$ 2$ for 10 ; open ground, 2 to $3 \mathrm{ft}$. $50 \mathrm{cts}$. each, $\$ 4.50$ for 10 .

In named varieties we can furnish the following extrachoice, large-sized, fruity sorts which we can especially recommend to all planters:

ADVANCE. Secdlings, pot-grown, small, 35 cts. each, $\$ 3$ for 10 . Scedlings from open ground, strong, 2 to $3 \mathrm{ft}$., $50 \mathrm{cts}$. each; 3 to $4 \mathrm{ft} ., \$ 1$ cach; 4 to $5 \mathrm{ft}$., $\$ 1.50$ each; nice grafted stock in pots, strong, $\$ 1.50$ each.

EARLY RED. Strong grafts in pots, $\$ 1.50$ each.

PINEAPPLE. Seedlings, in pots, small, 35 cts. each, $\$ 3$ for 10; strong, grafted plants, in pots, $\$ 1.50$ each. 


\section{ROYAL PALM NURSERIES}

FICUS CARICA. Fig. HW. One of the most delicious ICUS of all fruits, which does well along the Gulf Coast. In Florida, owing to presence of nematodes, care must be taken in heavy mulching (preferably of stones or brick-bats) as a preventive, or planting close up to buildings under which the roots will be shaded. Another excellent plan for growing Figs in South Florida is the following: Make ridges in mucky swamps or ponds so the surface is above high water. Set Fig trees on these ridges and fertilize with chemical fertilizers and poultry droppings. Mulch the surface.

Prices of trees, 2 to $3 \mathrm{ft}$, $40 \mathrm{cts}$. each, $\$ 3.50$ for 10

BROWN TURKEY. Good size, yellowish brown; pulp tender, rich and of finest quality; long stems.

BRUNSWICK. Fruit large, dark violet in color; flesh white and pink. Very strong grower and prolific fruiter.

CELESTE. Often called "Sugar Fig," as its fruit is so very rich and sweet. A small fruit, brownish ycliow, borne in profusion. Very hardy.

GREEN ISCHIA. Skin a light green color; flesh white, with light red center. An upright grower and hardy.

LEMON. Large, lemon-colored fruit, ripening early.

HICORIA PECAN. Pecan. HW. Pecan nuts form a IICORle crop in the South and fine, Iarge nuts

bring high prices. The industry is a safe one in the proper Iatitude. The Lower South has an immense area of excellent soil, suitable for these trees. In Soutli Florida select good medium high land with yellow or chocolate subsoil, and give moderate amounts of manure. Price of standard size, 4 to $5 \mathrm{ft}$. trees, $\$ 1.50$ each, $\$ 14$ for 10 .

CURTIS. One of the very best for South Florida planting both in respect to bearing and quality. Mediun in size with bright, clean, thin shell and full, plump, yellow kernel of rich, nutty flavor.

FROTSCHER. This is doing very well in South Florida, and we recommend its more extended planting. A large oblong nut about $1 \frac{3}{4}$ inches long, with very thin shell. Kernel large, easily removed, of delicious flavor. Tree vigorous in growth and a heavy bearer.

STUART. One of the oldest named sorts. Nuts of large size and of splendid flavor. A heavy bearer.

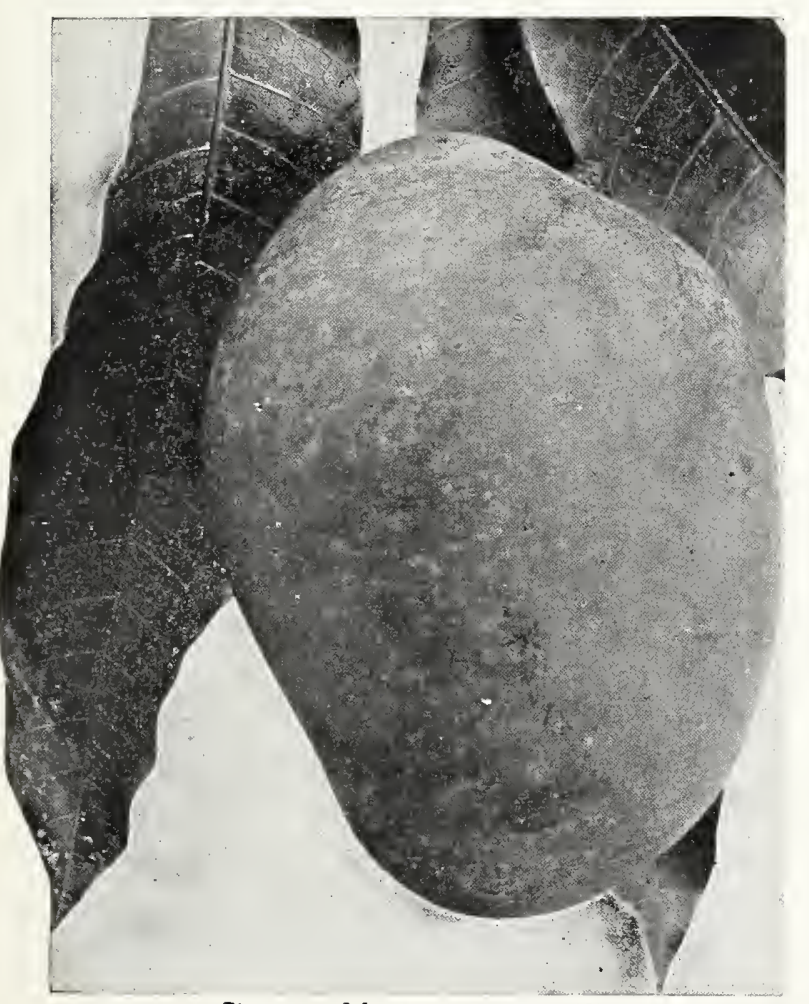

Singapur Mango (see page 48)

\section{LITCHII CHINENSIS. Litchee Fruit. ST. Native to} China. A tree of medium growth with dense, very handsome foliage. While the fruit of the ordinary kinds is of small size and mediocre, our stock is from the finest strain of large-fruited improved sorts, layered from fruiting trees. Our parent trees fruited for the first time in 1916 and the fruits proved to be of very large size, 1 1/2 inches: long, and $13 / 8$ inches thick, most of them having no seeds. The fruit hangs in clusters, having a thin, roughened, tough skinlike rind, of a brilliant red color when ripe, and the translucent white flesh is firm and jelly-like in consistency and of exquisite refreshing flavor. This promises to be one of the most prominent fruit crops of the state, both because of its popularity with those to whom the fruit is familiar and also because the tree is hardier than the mango-about like the lemon. The dried fruit is not unlike raisins, in which form it is shipped in Iarge quantities from China. It is also preserved in several forms. The Litchee was first introduced by us about fifteen years ago, one of the trees fruiting in California in 1914. Strong layers from fruiting specimens, pot-grown, $\$ 3.50$.

MANGIFERA INDICA. Mango. T. One of the South Florida. We have been importing the delicious East Indian varieties for years, and we were the first to inarch these in Florida, bcginning in 1887. Our stock is probably the largest in Florida. All sorts named are East Indian varieties of exceptional value, almost or cntirely devoid of fiber. These should be planted everywhere in South Florida (and of course in the Tropics generally); in Florida in protected spots or else protected as per suggestions on page 5 .

Nothing comparcs with the improved Mango for table use, and even one tree is worth a lot of trouble to grow, as grafted stock bears early and abundantly.

Mango fruit is delicious sliced like peaches for dessert; the fruit may be cut around on the "edge" and twisted apart easily in some of the best sorts as Haden, Cambodiana, Langra Benarsi, Totafari, Paheri, Sandersha, and the like, and the pulp scooped with a spoon from the center, leaving the skins, as one does in eating grapefruit. Mangos are also used in a number of ways cooked-preserved, canned, marmalade, chutney, pickled, and the like.

Our plants are all inarched (or grafted) on to pot-grown 2-year-old seedlings, and may be set safely at any time of the year, being strong and vigorous trees, well rooted. Pot-grown stock is the only safe stock to handle, as the Mango when transplanted from the open ground is very likely to die except in very large specimens.

Prices on all sorts, for strong, inarched plants, pot-grown, $\$ 2$ each, $\$ 18$ for $10, \$ 160$ per 100

CAMBODIANA. Very rapid grower, bearing medium to large fruit; early ripening; color yellow; shape long; rather more acid than most sorts if gathered before coloring, but when ripened on the tree quite sweet. Very fine sort, without any turpentine taste. One of the best, both as to quality and bearing habit.

GOA ALPHONSE. This is one of the most attractive fruits yet fruited here and is of excellent quality. Considered one of the finest grown around Calcutta. Of large size and bright red cheek.

HADEN. A fine variety originated by the late Captain Haden, at Cocoanut Grove, Fla, from seed of Mulgoba. Has high color, clear yellow and with a brilliant red cheek; quality similar to the parent, and much more prolific. Very popular in Dade County and considered by many superior to Mulgoba in all respects.

ITAMARACA. One of the most unusual Mangos we have yet fruited. Of flat, tomato-like shape, weight averaging from 6 to 10 ounces. The quality is excellent, being spicy and distinctive, and the tree has the added virtue of being a prolific bearer.

LANGRA BENARSI. One of our introductions from India, which bore in 1910 for the first time. This has proved very prolific and is a strong grower. The fruit is the largest we have ever seen, weighing up to 3 pounds, 12 ounces each Very little fiber, flavor rich and juicy; color of skin yellow or greenish yellow.

PAHERI. Imported by Department of Agriculture, and fruited in 1910 for the first time in Florida. One of the finest sorts grown in India. General form is roundish, about $35 / 8$ by $3 \frac{3}{8}$ inches. Skin thick, yellow and green when ripe, touched with garnet-red on the sunny side-very attractive. Flesh yellow, tender and juicy; sweet and aromatic. Of very highest quality. 


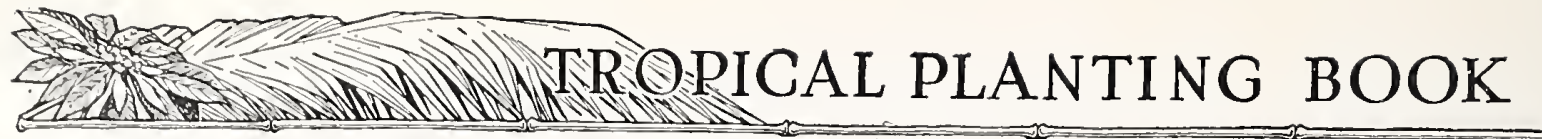

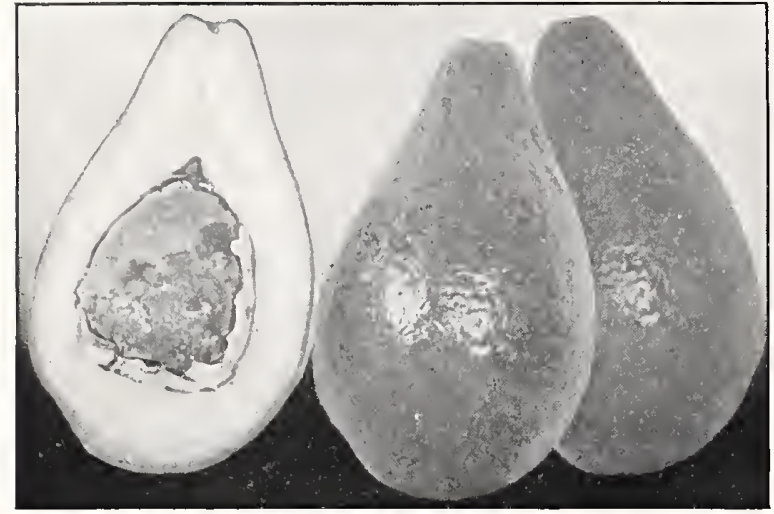

The Lula Avocado

TREE FRUITS, continued

MANGIFERA, SANDERSHA. So far as known, the latest to ripen. Fruit long, yellow, large size, sometimes nearly 3 pounds each. Flavor good, but somewhat acid.

SINGAPUR. Our own importation, which fruited for the first time in 1911, and proved to be all that was claimed for it by our Indian correspondent. The skin is green and golden yellow, finely mottled, thick and strong, with a grayish blue bloom, clean and free from spotting. The flavor is distinct, rich and sweet, with characteristic true Mango flavor. The fruits are remarkably uniform in shape, meaty, thick and solid-perfect, weighing from 14 to 20 ounces each.

TOTAFARI. One of the best sorts, resembling Sandersha, but only about half the size. Bears well when very small, and is prolific.

SEEDLING MANGOS. P. From Number Eleven. $50 \mathrm{cts}$. each, $\$ 4$ for 10 .

SEEDLINGS MIXED. P. 1-yr., 25 cts. each, \$2 for 10.

MORUS ALBA. Mulberry. HW. A very useful tree borne in profusion; of value for hogs as well as for human consumption.

Prices, 4 to $5 \mathrm{ft}$. high, $60 \mathrm{cts}$. each, $\$ 5$ for 10

MERRITT. Very early; berries large, black, and of cxcellent flavor.

STUBBS. One of the very best, following the preceding in ripening. Fruit of largest size, Iargely used in cooking and for bottling the juice.

OLEA EUROPÆA. Olive Tree. H. Our stock is of the celebrated "Mission" variety, and while we do not recommend it for fruiting purposes at all, it makes a very lovely lawn tree and for lining alleys in gardens. Of erect habit and, with age, a knarled, twisted character, it makes a pleasing picture for the home grounds. The foliage is willowy and of a soft gray that lends a delightful suggestion of long distances. P. Strong, vigorous plants, \$1.50 each.

PERSEA AMERICANA. Avocado; Aguacate; Alligator

The Avocado is unquestionably Florida's most valuable food-crop, acre for acre. It ranks with milk and cggs and is fully equal to lean meat, and in addition has the medicinal quality of a soothing laxative character, being easily assimilated by the most delicate digestion.

In serving this salad fruit in Florida it is customary to add either just salt or pepper or lime juice, or combinations of these. We recommend a lime or Icmon trec with every planting of Avocados for home use, or, wherc neither of these would be hardy, a Calamondin tree, or Eustis Limequat.

Culture. - The Avocado succeeds on a wide range of soils, from quite high lands to relatively low ones if sufficiently well drained to climinate danger of standing water around the erown-roots.

However, it is desirable that the soil should contain a large amount of organic matter, and where this is not naturally plentiful it can be remedied with liberal applications of muck, well-rotted manure, or similar materials.
Good preparation for Avocados is vcry desirable-indeed essential for good results. Dig a hole 2 fcet deep and 3 feet across, being sure to get through any hardpan, and fill in with top soil, incorporating liberal applications of wcllrotted manure if obtainable, or well-aërated muck of good quality, marl or an cquivalent amount of lime by analysis, as well as a pound or so of good commercial fertilizer from organic base, such as blood-and-bone, tankage or something of the kind. Unless drainage of the land is good, mound the trees up 10 to 18 inches above the general level, making the mounds about 5 feet across. This will serve to shed surface water from the crown roots anyway. Or better than just mounding would be to plow the land into ridges and deadfurrows, in the dircction of the best outlet.

As the Avocado is partial to organic fertilizer, and as the nitrogen-gathering cover-crops are a cheap and effective form of fertilizing, we recommend the growing of such legumes as beggar-weed, cowpea, velvet bean, etc., as much as possible in the scheme of culture adoptcd.

Our Avocados are all box-grown, the only rational way to retain all the root-system and permitting shipment to any point in perfect safety. In planting trees so grown, care should be exercised to disturb the roots as little as possible. After removing bottom board, set the boxed tree in the place prepared for it so the soil after planting will come about 1 inch above the soil level in the box, split one side with a hatchet, pull up the box, packing the soil carefully around the roots. After planting, mulch the ground well with any coarse material available, taking care not to have it close to the stems-this might encourage both insects and disease.

For remarks on frost protection see page 5 of catalogue. It may seem paradoxical to talk of protection for the hardier Avocados, especially in South Florida, but while young these trees slould be so carcd for-even though they might be perfectly hardy in later years, for the first two or three winters it is always good policy to take no chances where possibility of such injury exists.

\section{PRICES ON AVOCADOS}

(All budded and grafted stock is box-grown) BARKER, FAMILY, and TRAPP, \$1.50 each, \$13.50 for 10 . FUERTE, GANTER, GOTTFRIED, HARMAN, NORTHROP, SAN SEBASTIAN, and PUEBLA, \$2 each, \$18 for 10. LULA, NIMLIOH and QUEEN, \$2.50 each, \$22.50 for 10 . MIXED FLORIDA SEEDLINGS, box-grown, 50 cts. each, $\$ 4$ for 10 .

MEXICAN SEEDLINGS. P. 50 cts, each, \$4 for 10.

\section{Tropical South American ("West Indian") Type}

This is the most tender of the thrce groups of Avocados, showing pronounced injury at 28 dcgrees Fahr. They may, however, be grown safely in a considcrable area of the state where natural protection is best, as on the East Coast below Ft. Pierce, the West Coast at protected places south of the Caloosahatchee River., and at other specially protected places throughout extreme South Florida. The special characteristics of this class, aside from susceptibility to frost, are a thick leathery skin that separates readily from the flesh; the flesh is not as high in fat content as the Guatemalan; and the seeds are large and often loose in the cavities. The following are the best of this group:

BARKER. A splendid new variety, originating at Bradentown, closely resembling Pollock as to general appearance, size and quality, but a heavy and constant bearer, and probably more hardy. Season, October into December. Weight of fruit from 1 to 3 pounds; grcen-skinned.

FAMILY. This is the earliest to ripen of this group we are listing-from early July to last of September. The flesh is greenish cream colored, of mild, pleasant flavor, but not very rich. In form it is slender pcar-shaped; in color, maroon-red; seed, large and tight in cavity. Tree productive.

TRAPP. This is the variety most commonly planted in Florida, probably comprising 90 per cent of the groves of budded trees. The fruit is medium in size, 1 to $11 / 4$ pounds in weight, smooth, grcen skin, sced somewhat loose in cavity. Flesh grcenish vellow, free from fiber, and of rich, pleasant flavor. The fruits commence ripening in October and hang on to the first of the year and somctines considerably longer. 


\section{ROYAL PALM NURSERIES}

\section{The Hardier Avocados}

\section{GUATEMALAN TYPE}

This is intermediate between the South American and hardiest Mexican types, and from the commercial viewpoint bids fair to succeed the tropical varieties in point of favor with the planter, both because of the larger area in which it can be planted, the character of the skin which makes it an unusually good shipper, and the lateness of the ripening season. This latter point is not yet fully established in respect to all varieties, but the seasons we indicate are probably fairly close approximations.

In hardiness this group is probably about like the lemon, possibly much more hardy. However, because of the fact that this type, contrary to the others, blooms in late spring and carries its fruit over the following winter, ripening the next spring or summer, special attention should be accorded the consideration of protection, naturally by location, or artifically. The skin is characteristic, very thick, even to the point of being woody and brittle, and usually more or less rough. The flesh is considered better on the average than the South American type, being somewhat rieher and more oily, though not as much so as the Mexican. The seed is not large in proportion to the size of the fruit and is seldom loose in the cavity. It is an excellent shipper, and for this and other reasons may supplant the more tender varieties on the markets. Following are the varieties we are handling which from present knowledge we consider best adapted to Florida planting:

FUERTE. This variety originated in Mexico, and is now considered a hybrid of the Guatemalan and Mexican types, is of unusual hardiness for the former type and at present a general favorite for orchard planting in California, the fruit ripening here from late November to March. The fruits are oval in shape, weigh about a pound each, with a green skin, rough in surface, and thick in texture. The flesh is yellow, smooth and buttery, rich in flavor (analyses showing 25 per cent fat) with a small tight seed.

LULA. A late ripening sort-December to March-in form pear-shaped and color green. It weighs one to $11 / 2$ pounds, packing 28 to 46 to the crate. A Guatemalan-Mexican hybrid, it has about the same degree of cold-resistance as Fuerte, possibly more.

NIMLIOH. Introduced from Guatemala by the Department of Agriculture, fruited out in Florida and found very desirable. Season of ripening February and March; green skinned; weight $1 \frac{1}{2}$ to $2 \frac{1}{2}$ pounds; shape oblong or oval.

QUEEN. Purple fruit weighing about $1 \frac{1}{4}$ pounds, pearshaped, flesh rich and nutty-flavored, and seed small and tight in cavity. The variety is one of the most promising for Florida growing. Spring ripening; prolific.

\section{MEXICAN TYPE}

Because of its extreme hardiness this type should receive special consideration from every home-owner in the central and northern portions of the state. From the commercial aspect they are usually considered of little value, chiefly because of their small size, but as the varieties we list of this type are so very resistant to cold, vigorous and remarkably productive, and of such rich flavor and fine quality, they are absolutely indispensable. Practically hardy in maturity over the greater portion of the state, every home place, in town or country, outside of the range of the more tropical sorts, should have at least one to three trees of this delicious salad fruit, and in conjunction with them should be planted a Calamondin orange. This type bearsearlier than the others, in seediings as well as budded trees, and specimens have been known in some instances to have produced crops of 4,000 fruits to the tree. The skin of the fruit is thin, and the foliage has an anise-like odor when crushed that differentiates this group from any other.

GANTER. The famed $\$ 30,000$ tree in California is the original seedling from which the budded trees are taken. Fruit is small, 3 or 4 inches long, and weighs from 4 to 9 ounces; skin green; flesh very rich usually, 25 per cent of fat; ripens early (summer) and very prolific.

GOTTFRIED. Originated at the Plant Introduction Garden in Miami. Original tree is of large size and has never been injured by cold. Fruit pyriform, weighing from $3 / 4$ to $11 / 4$ lbs. each, ripening from August to October. Skin of fruit very dark brownish purple; seeds small; fruit of exceedingly good quality and rich.
HARMAN. Fruit rather small, with a smooth, glossy, greenish purple surface and seed loose in the cavity. The creamy yellow flesh is of fine buttery quality and rich flavor. The tree is erect and unusually vigorous, very heavy bearer, ripening its fruit here in July and August.

NORTHROP. Slightly smaller in size than Harman, it is more pear-shaped and the surface is smooth, glossy, and of purplish black color. The cream-colored flesh is of fine, smooth texture and rich flavor, analyzing 25 per cent fat. Seed is medium in size and tight in cavity. The tree is very hardy and vigorous, ripening its fruit in August and September in Florida, with a second lighter crop in spring. This alone would mark it as one of the most valuable sorts for the Florida planter.

PUEBLA. Erect and rapid growing, this variety is a young and prolific bearer. Somewhat pear-shaped but not necked, the fruits weigh about 10 to 12 ounces each, with a smooth, tough, thick skin, smooth, rich flesh, and with small seed tight in cavity. Season, September to November.

SAN SEBASTIAN. This variety, unlike the preeeding ones of this group, originated in Mexico. The fruit is oval and larger in size than some of the others, weighing up to a pound. The skin, too, is rather thicker and black in color. Seed medium in size and tight in cavity; the yellow flesh is of fine, rich flavor. The tree is a strong, rapid grower and unusually hardy. Season in Florida, June and July or later.

TAMARINDUS INDICA. T. Tamarind. Tropical Asia and Africa. A large, handsome tree with fine feathery foliage, making an excellent shade tree. The fruit is a brownish pod 3 to 4 inches long, containing acid pulp. P. 50 cts. each, $\$ 4.50$ for 10 .

ZIZYPHUS MISTOL. T. Argentina. A small spiny the jujube of commerce, and bearing small, edible fruit with large seeds, P. 50 cts.

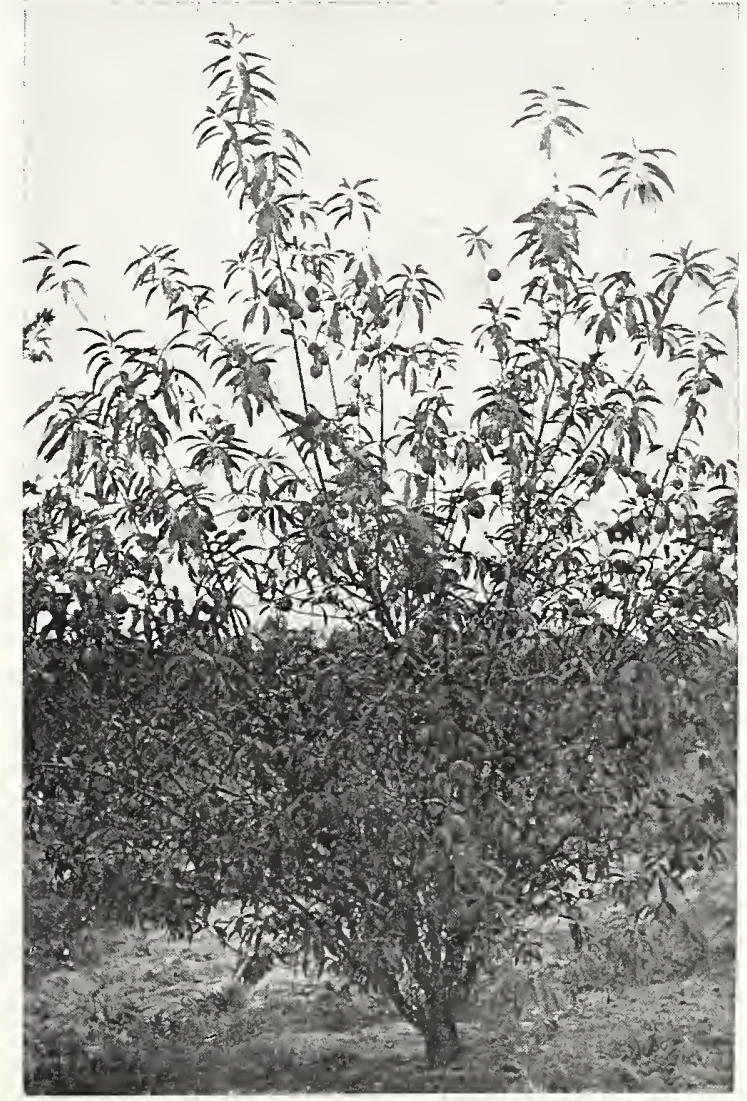

Peach tree in fruit 


\section{Group II. Fruiting Shrubs, Vines, and Other Plants}

ANANAS SATIVUS. Pineapple. T. Those desiring ANANAS large quantities of either slips or suckers should write us, stating number required, and get a net estimate. As this splendid tropical fruit can be grown so easily - a few plants can be set around under orange and grapefruit trees-they should be more generally considered by the home owner. Fruit of most excellent quality can be produced this way over most of South Florida, with relatively little care or attention beyond most simple needs. Rooted plants in stock as follows:

RED SPANISH. The ordinary commercial sort so largely grown. 15 cts. each, $\$ 1.25$ for $10, \$ 10$ per 100 .

SMOOTH CAYENNE. The only sort without spines on the leaves. A very valuable sort, now extensively grown in the Tropics, both for shipping fresh and canning. This is a fine variety for the home garden, as it bears almost any time throughout the year. $20 \mathrm{cts}$. each, $\$ 1.50$ for $10, \$ 12$ per 100 .

CARICA Papaya. Papaw or Melon Fruit. T, Tropical America. Fast-growing, herbaceous and branchless tree, 15 to $20 \mathrm{feet}$, of ornamental foliage and bearing numbers of delicious, melon-like fruits, which are highly esteemed for dessert and as an aid to digestion because of the papain they contain. Plants are potgrown from choice seed. As the flowers are dicecious, several plants-we recommend at least five-should be planted to the group. P. $15 \mathrm{cts}$. each, $\$ 1.25$ for 10 .

CARISSA Grandiflora. Amatungula T. Natal. Handsome ornamental evergreen shrub, of glossy green foliage with elegant white flowers and conspicuous scarlet fruits about $1 \frac{1}{2}$ inches long, which can be eaten raw or can be cooked like cranberries, which fruit it resembles in taste. Plant is thorny, and is admirably adapted to hedge purposes wherever hardy. Grows exceptionally well near the seacoast, standing both wind and spray. P. Layered plants from fruiting bushes, 50 cts.

EUGENIA UNIFLORA. Surinam Cherry. T. Large UGENIA shrub bearing rather small bright, waxy red fruits of agreeable sub-acid flavor, eaten raw or as jelly. Under ligh culture bears two heavy crops yearly. Nice for growing in pots and tubs at the North as foliage and fruit are attractive at all times. Pot-grown seedlings from best fruit. $25 \mathrm{cts}$. each, $\$ 2$ for 10 ; larger, $35 \mathrm{cts}$. each, $\$ 3$ for 10 .

BLACK FRUITED SURINAM CHERRY. Similar to preceding except in color. P. Seedlings, 35 cts. each, $\$ 3$ for 10; larger, $50 \mathrm{cts}$. each.

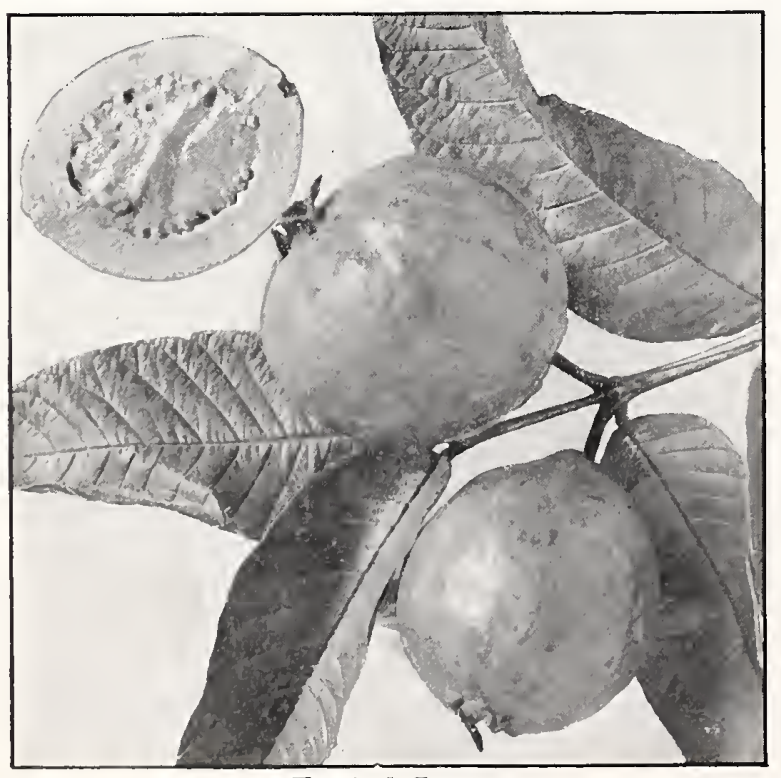

Tropical Guava
MONSTERA DELICIOSA. Ceriman. T. Trinidad. A climbing aroid plant with enormous, handsome pert use leaves and bearing fruits about the size of bananas, the "coats" of which are as easily removed, and resembling in taste an imaginary cross between pineapple and banana. P. $\$ 1$ and $\$ 1.50$

PASSIFLORA EDULIS. Granadilla. T. Brazil. mental foliage and handsome white and purplish flowers, followed by a purple fruit $11 / 4$ to 2 inches thick; this has a hard rind: cavity filled with a delicious juicy pulp in which are numerous small seeds. Makes a splendid porch vine. The juice is used in cold drinks, sherbets, and ices, also in cookery. While the top is liable to frost injury, the roots will stand anywhere in South Florida and quickly renew the top. P. 25 cts. each, \$2 for 10 .

P. LAURIFOLIA. Water Lemon. T. West Indies. A handsome climber with laurel-like foliage and bearing fruit the size of hen eggs, with smooth yellow rind when ripe, and containing a sweet watery pulp. An excellent vine for decorative purposes. P. $50 \mathrm{cts}$.

PSIDIUM. Guava. A grand fruit in all its varying SIDIUM. forms, even the tropical sorts being of special value to Florida because of their surety to sprout up after being cut down by frost, and bearing after one frostless winter.

The fruit is always borne in enormous quantity and varies in size, color, acidity, juiciness, and seediness, our aim being to propagate from the very finest types we can secure, and to offer only the best. We grow many thousands of plants yearly from seed only, and offer the following kinds, all of which are valuable for cooking, canning, preserving, making jelly, and the like, or may be used in the fresh state with sugar and cream, being only second to finest peaches. This is an especially interesting prospect for commercial fruit growers, and one that will be extremely profitable once this fruit is more widely known. AIl stock is pot-grown, and may be transplanted any time.

\section{Hardier Cattley Type}

P. CATTLEYANUM. Red Cattley Guava. ST. A vigorous evergreen shrub standing sharp frosts, having handsome broad evergreen leaves. Fruit small, averaging about an inch in diameter; borne in enormous masses, ripening in August. Color a pretty red. Fruit is juicy, and subacid, good in many ways. A fine plant, also of especial value for making hedges in South Florida, as it is unusually free from insect pests, such as white flies and scale. Pot-grown, small, $15 \mathrm{cts}$. each, $\$ 1.25$ for 10 ; strong plants, $25 \mathrm{cts}$. each, $\$ 2$ for 10 . heavier, $35 \mathrm{cts}$. each, $\$ 3$ for 10 ; extra heavy, $50 \mathrm{cts}$. each, $\$ 4.50$ for 10 .

P. LUCIDUM. Chinese or Yellow Cattley Guava. ST. Resembles Cattley Guava rather closely in growth, though not so compact and bushy, bearing an abundance of yellow fruit somewhat larger than Cattley and sweeter. Prices same as for preceding.

\section{Common Tropical Guavas Psidium guayava}

Fruits are variable in size and shape, sweet, subacid and sour, and largely in demand for making jelly, marmalade, cheese, and all manner of preserves. We grow this largely, and al from seeds of the most distinct and valuable fruits. Select sorts follow, of which we consider a large majority of the trees will bear true to dest

SNOW WHITE. A large, fine, subacid dessert Guava. P. 15 to 18 in., $25 \mathrm{cts}$. cach, $\$ 2$ for $10 ; 18$ to 24 in., $35 \mathrm{cts}$. each, $\$ 3$ for 10 ; larger $50 \mathrm{cts}$. each.

SOUR. Selected fruits for jelly and preserving. P. 12 to 15 in., $25 \mathrm{cts}$. each, $\$ 2$ for $10 ; 15$ to $18 \mathrm{in}$., $35 \mathrm{cts}$. each, $\$ 3$ for 10 .

SWEET. Sclected dessert fruits. P. 15 to 18 in., 25 cts. each, $\$ 2$ for $10 ; 18$ to 24 in., 35 cts. each, $\$ 3$ for 10 .

White PERUVian. A sweet, large fruit. P. 2 to $3 \mathrm{ft}$., $50 \mathrm{cts}$ 


\section{ROYAL PALM NURSERIES}

COMMON TROPICAL GUAVAS, continued

YOUNG SEEDLINGS. We can furnish a fine stock of the following varieties, 10 to 12 inches high, pot-grown, at $15 \mathrm{cts}$. each, $\$ 1$ for $10, \$ 7.50$ per 100 .

CALCUTTA APPLE. Smali, acid fruit full of pectin, especially fine for use with other sweeter sorts in jelly making.

PINK GUINEA. A fine sweet dessert sort.

SOUR.

SOUR PERICO.

SOUR PINK.

SOUR WHITE.

SWEET PINK.

WHITE GUINEA. Fine, large dessert.

WHITE SUBACID.

PUNICA Granatum. Pomegranate. HW. A large-sized fruit with thin, tough rind. The flesh is a beautiful wine-color, crisp, sweet, and of exquisite flavor. Very attractive as a shrub, with flowers of reddich orange effect. Strong plants. 3 to $4 \mathrm{ft}$., $50 \mathrm{cts}$. each, $\$ 4.50$ for 10 .

\section{RHODOMYR'TUS TOMENTOSA. Downy} this shrub is so valuable for culinary purposes, making a pie suggestive of huckleberry but with thicker, richer juice and of a flavor all its own, and makes a rich fine jelly when blended half-and-half with Guava. P. 35 cts. each, $\$ 3$ for 10; larger, 50 cts. each, $\$ 4$ for 10.

RUBUS CUNEIF OLIUS. Blackberry. H. Native. May and June. 15 cts. each, $\$ 1.25$ for $10, \$ 8$ per 100 .

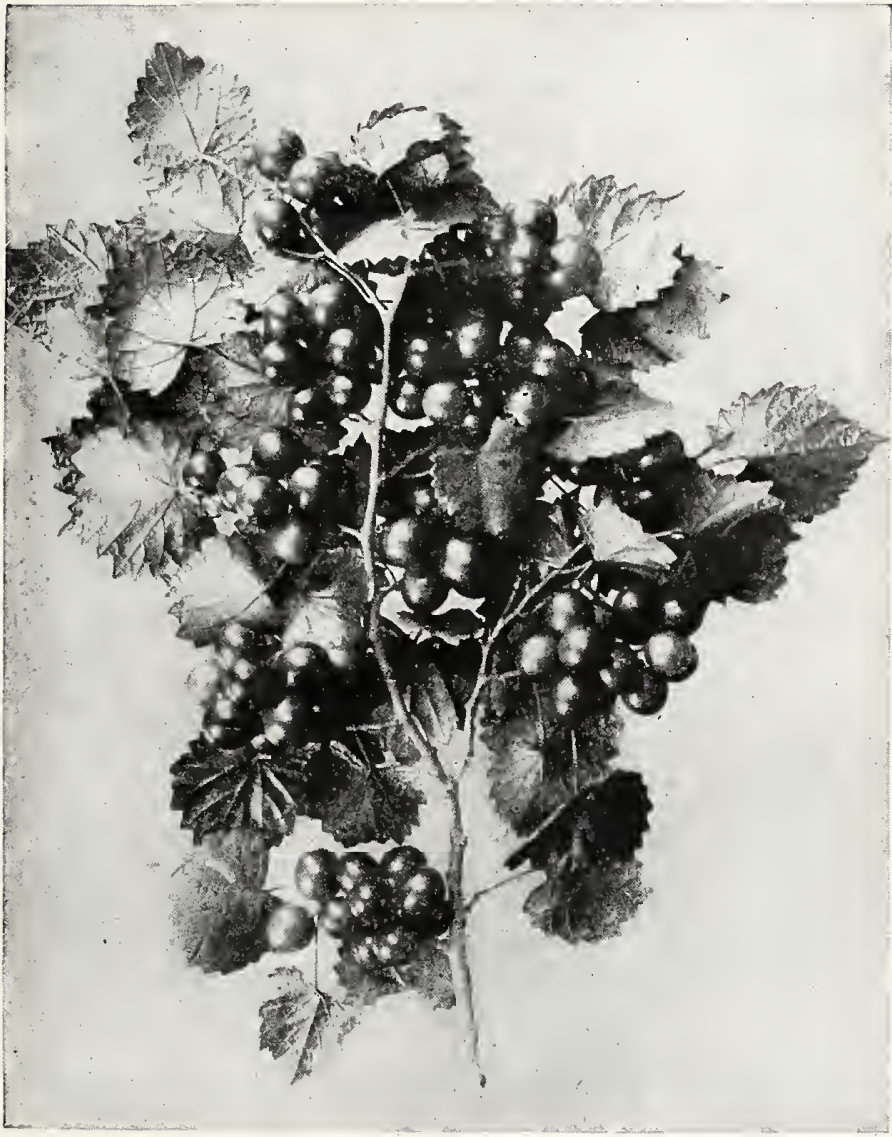

Muscadine Grape. Valuable for its juice
R. HYBRIDUS. Northey Berry. Resembles the Dewberry in growth. Fruit purplish in color, good sized and of exquisite flavor. Set 5 to 8 feet apart and train on a wire 3 or 4 feet high. Ripens in late April and May. $25 \mathrm{cts}$. each, $\$ 2$ for $10, \$ 15$ per 100 .

R. TRIVIALIS. Manatee Dewberry. H. A delicious black fruit of great value, ripening in late April and May, 15 cts. each, $\$ 1$ for $10, \$ 7$ per 100 .

UVARIA RUFA. T. Asia. A scandent shrub, related

18 to 28 oblong, velvety berries, deep red when mature, containing a whitish, a romatic, acidulous fleshy pulp. P. 50 cts. each, $\$ 4$ for 10

VACCINIUM VIRGATUM. Orchard Blueberry. $\mathrm{H}$. prominence in the horticulture of the state only recently is unquestionably one of the most valuable brought forward in many years. While in reality a shrub, it attains a height of 10 to 12 feet, and is planted in rows 15 to 20 feet apart, and 10 to 12 feet apart in the rows and cultivated like any orchard fruit. The berries average $1 / 4$ to $3 / 8$ inches in diameter, blueblack in color, and in quality equal to the best New England blueberries from which they are scarcely distinguishable. The season lasts from late May to August. We cannot recommend this for high, dry lands to which the plant is not suited-it prefers a moderately moist soil- rood corn land, and one at least slightly acid. In view of the scarcity of good berry plants in Florida, too much attention cannot be given to this matter-we urge careful and thorough investigation by all horticulturists, especially those interested in the growing of fruits for local markets. Good strong plants, 50 cts. each, $\$ 4.50$ for 10 , $\$ 40$ per 100 .

VITIS ROTUNDIFolia. Muscadine Grape. HW. A very vigorous type of Grape, needing large, well-built arbors, to support its great loads of fruit The is the Grape for Florida and our Gulf Coast country generally. Set vines 15 to 20 feet apart and train up early on arbors 8 fcet high. Make arbors of best material so that they will be permanent structures for many years. Prune out the dense part of these vines every Novemout the dense part of these vines every Novem-
ber or December, so that light and air can get to all growth; old crowded vines are no good except along the edges of arbor in the newer growth. These vines all need pollen from the male muscadine or from male vines of Vitis munsoniana; the former very abundant in the Carolinas, the latter in South Florida Especially valuable for securing proper pollination are bees, and for those contemplating the extensive growing of Grapes it would be well to provide for this accordingly.

Following is a select list of choice sorts which are doing splendidly in Florida.

Price of all sorts for strong 2-year vines, $40 \mathrm{cts}$. each, $\$ 3.50$ for 10

FLOWERS. Of medium size, black, ripen very late, after all others are gone. Sweet, tough-skinned. An excellent sort for prolonging the Grape season.

JAMES. Berry very large, black, or purplish black, very sweet. Ripens here in August and frequently has a second crop in October or November.

MISH. A new sort of medium size, in color purple. The earliest to ripen here. Has a delicate but rich flavor of the very highest quality. Where an early Grape is desired, this will be found most satisfactory.

SCUPPERNONG. Greenish amber in color, of a delicious and distinctive flavor, this famous Grape is high in the estimation of all horticulturists, both as fruit and wine-maker. The berry is very large, ripening in August and early September. This fine variety should receive first consideration in every planting of Grapes.

THOMAS. Medium-sized fruit in small clusters but of fine quality. Makes exceedingly rich, fine-flavored grape-juice and is largely planted for this purpose. 


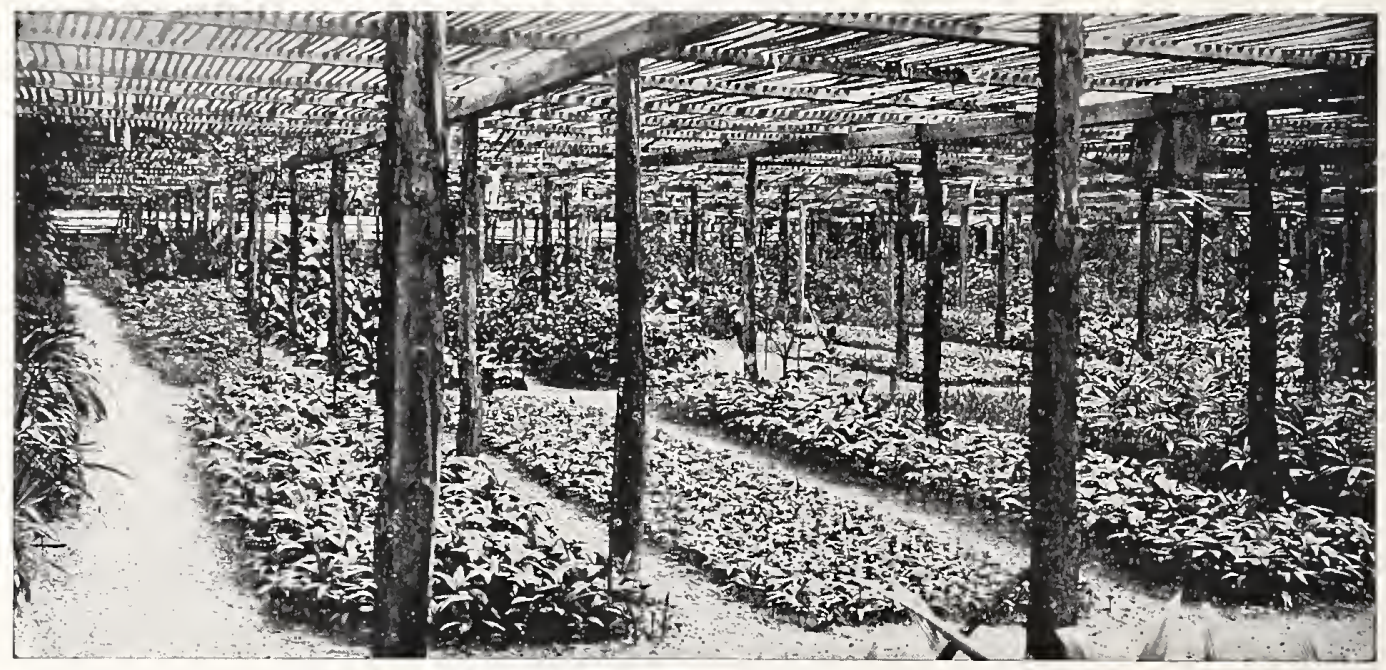

A Million Plants-That's why we need an Index

\section{CONTENTS}

Business Rules.

The Reformation of Mr. Billings

Landscape Service Department

Planting and Potting Suggestions.

Palms and Cycads...

Shade Trees

Bamboos and Grasses
Page

$.2 \mathrm{~d}$ cover

$.2-4$

4

6-11

12-17

$18-20$

\section{Flowering Plants and Shrubs. \\ Vines and Creepers.}

Decorative Subjects.

Ferns and Selaginellas.

Tuberous, Bulbous and
Fruit Trees and Plants

INDEX .... .
Page 21-32

33-36

$37-39$

39-40

41-43

44-51

.52

\section{INDEX}

\begin{tabular}{|c|c|}
\hline & \\
\hline .22 & $\begin{array}{l}\text { Azalca... } \\
\text { Baccharis. }\end{array}$ \\
\hline cacia $\ldots \ldots \ldots \ldots, 29,31$ & $\begin{array}{l}\text { Baccharis. } \\
\text { Balisier... }\end{array}$ \\
\hline & Bamboo, Arrow. \\
\hline ras......... 15,44 & Bamboo Crecper...... \\
\hline Acrocomia..........10 & Bamboo, Giant or Gol- \\
\hline Adiantum..... & den....$\ldots \ldots \ldots$ \\
\hline Eehmea............. 39 & Bamboo, Timber..... \\
\hline Afric a n Bow-String & Bambusa............ \\
\hline $\begin{array}{r}\text { Hemp............ } \\
\text { Agavc...... }\end{array}$ & Banana Shrub........ \\
\hline .48 & $\begin{array}{l}\text { Barbados } 1.10 \text { w e } \\
\text { Fence............. }\end{array}$ \\
\hline Plant........ & os Gooscbcrry . $3 t$ \\
\hline .36 & $\mathrm{Li}$ \\
\hline$\ldots 15$ & ia.... \\
\hline da......25, 35 & irass. . \\
\hline Pcar.......48 & tia. \\
\hline .42 & lood. . \\
\hline .42 & $\mathrm{Be}$ \\
\hline a.... & da Grass. . \\
\hline & $\ldots \ldots \ldots$ \\
\hline Privet & ry ... \\
\hline 44 & \\
\hline .50 & Orchard.29, \\
\hline pet. . & \\
\hline & $d w$ \\
\hline 45 & \\
\hline 29 & B \\
\hline nine... & $\therefore .26,34,3$ \\
\hline & \\
\hline & \\
\hline - Compact & per. \\
\hline 10 & \\
\hline & \\
\hline & Pine \\
\hline & nda. \\
\hline & \\
\hline & Butterfly Lily.... . \\
\hline tgus........35, 38 & Cabbage Palmetto. \\
\hline & \\
\hline Ian Pinc. & $\mathrm{Ca}$ \\
\hline & \\
\hline Avocado..... . 17, 46, 49 & \\
\hline
\end{tabular}

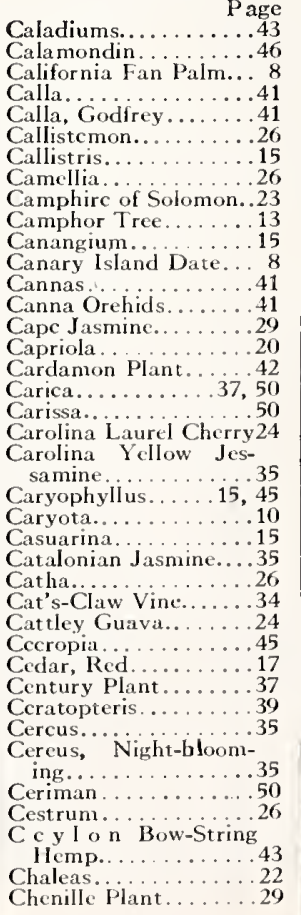

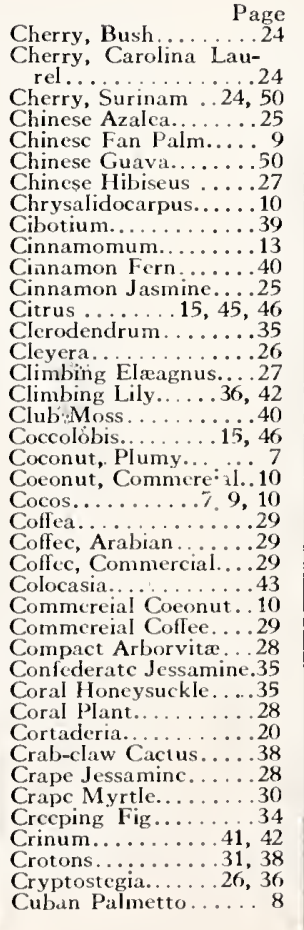

Cuphea........... Page

Cupressus

Curcuma...

Cycas.... . .

Cymbopogon

Cyperus.

Cypress Pine

Cyrtomium.....

Dasheen. ...

Date, Canary Island..

Date, Wild.

Datura.

mine.......26

Deguelia............36

Dendrocalamus.

Dendropogon.

Dendropogon ..........39

Dewberry, Manatec ..5

Dietyosperma.........11

Dioseorca................ 36

Diospyros..........46

Duranta...........26

Dwarf Poinciana.....26

Ebony, Whitc Moun-

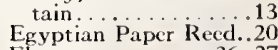

Elæagnus.......26, 27

Elæagnus, Climbing...27

Elais.

Elder, Yellow

Elephant's Ear....

English Ivy....

Enterolobium ...

Epiphyllum.

Eriobotrya.

Eucalyptus.

Eugenti....

Euonymus. 
Growers of NEW, RARE, AND BEAUTIFUL PLANTS, TREES, SHRUBS, PALMS, BAMBOOS, ETC.

FREE ILLUSTRATED CATALOG

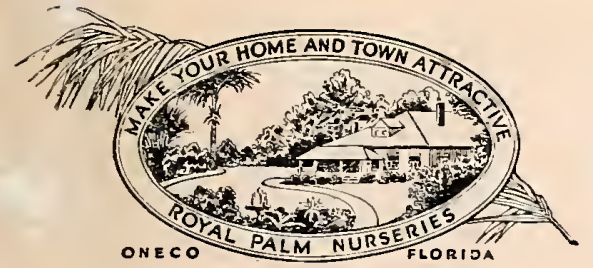

REASONER BROTHERS

ROYAL PALM NURSERIES

NURSERYMEN AND LANDSCAPE DESIGNERS ONECO, FLORIDA, U.S.A.

Gentlemen:

Send me on

(Specify date wanted)

by

the Nursery Stock listed hereafter, for which I enclose \$

Name $\left[\begin{array}{c}\mathrm{MR} \\ \mathrm{MRS} \\ \mathrm{MISS}\end{array}\right]$

Street and Number

Post Office

State

Express or Freight Office

Before making out your order piease read "Business Rules," Inside front cover. If requested, wo will bo glad to send more order sheets.

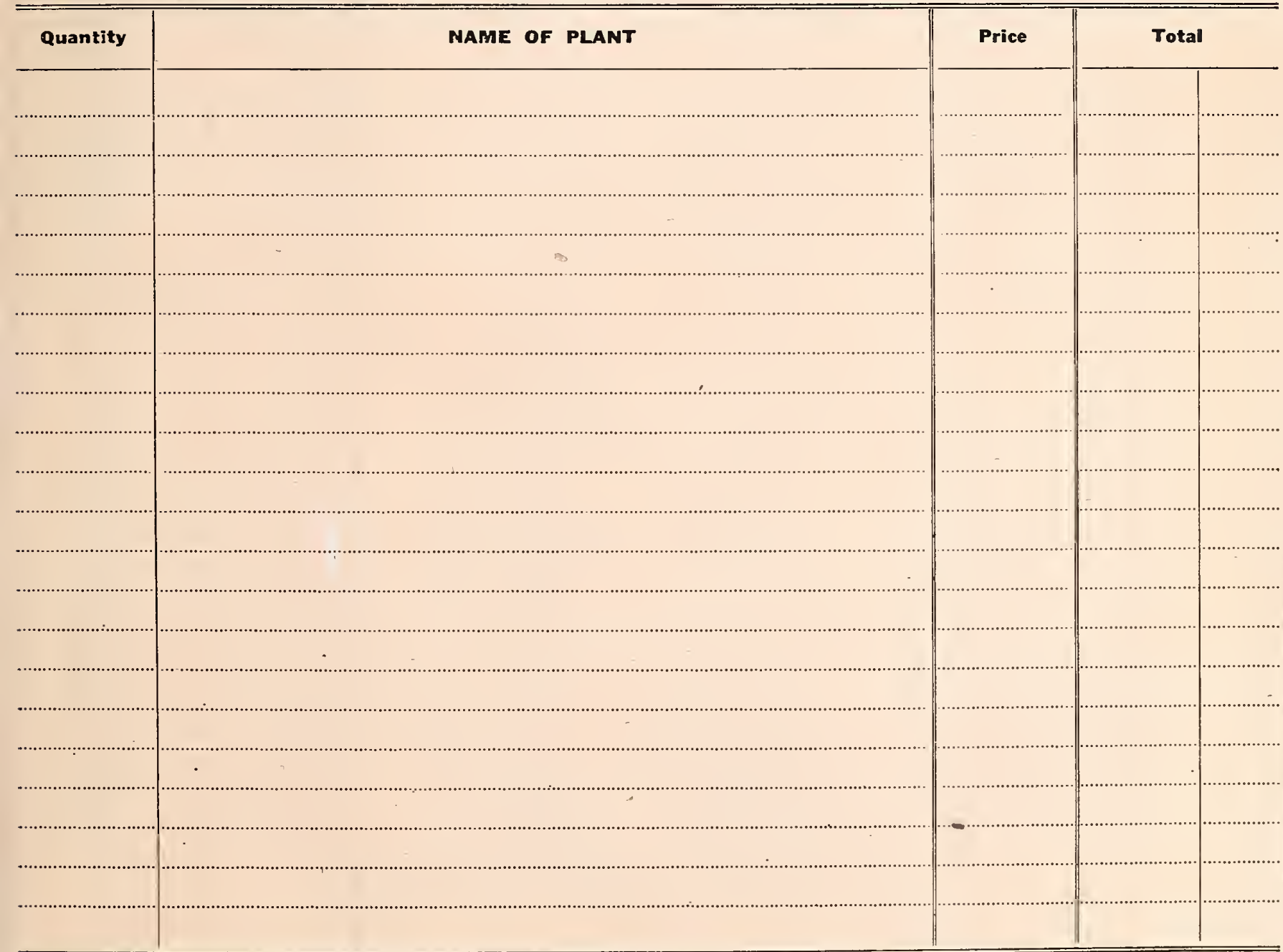


Euphorbia.........37, 38

Euphorbia.......... 37,38
False Ylang-Ylang....25 Fern, Boston..........40 Fern, Cinnamon........ 40 Fern, Glory...........

Fern, Japanese Climb-

Fern, Leather-leaf.....40 Fern Resurrection......40 Fern, Scott's Compact

Boston...

Fern, Silver............

$F$ e $r$, Stag-horn

Ferns.............. 39-40

Ferns, .............. 39-40

Fern, Tree........... 39

Fern, Victory $13,34,47$
Ficus.....13, 46,39

Fig............ Creeping or Climb-

Fig Tree, Moreton Bay 14 Fire Tree.

Fishtáil Palm

Flooded Gum.......34

Florida Privet.........22

Flower Fence, Bar-

bados..........26

Forestiera ..........28

French Hydrangeas....27

Gardener's Garter.....20 20

Giant or Golden Bam-

boo............... 19

Giant Palmetto....... 8

Gliricidia................. 16

Gloriosa.............. 36,42

Glory Fern ail.............

Godtrey Calia..........26

Golden-leaved Oleas-

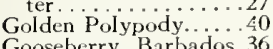

Gooseberry, Barbados.36

Granadilla...

Grapefruit ..

Grape, Muscadine....... 51

Gray Gum............16

Gray Moss...........3 39

Greenbriar............

Grevillea...............

Guava, Cattley.........24

Guava, Chinese ........ 5

Guava, Red Cattleya..50

Guava, Yellow Cat-

tley ..............50

Gum, Flooded.........16

Gum Trees...............16

Hall's Japan Honey-

suckle..............35

Hamelia..............27

Hawthorn, Indian....2.

Hedera............... 3

Hedychium............4

Heliconia............43
Hemigraphis........ 38

Hemigraphis..........38
Hemerocallis......... 42

Hemp, African Bow-

Hemp, Ceylon Bow-

String..............

Hemp, Sisal .............

Henna .............2
Hibiscus . 23

Hibiscus .......2.27
Hibiscus, Chinese...2.

Hibiscus, Chinese .....27

Hippeastrum............ 42

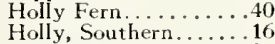

Honeysucklc, Coral....
Hon eysuckle, Hall's

Japan...........35

Hyacinth, Water......2

Hymenocallis.........42

Hyophorbe.......... 9
Hypericum..........

Ilex............... 16,24

India Rubber Tree....16

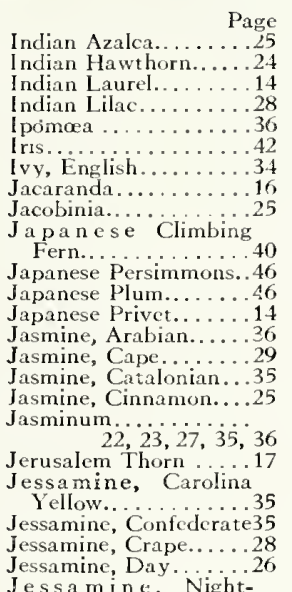

Jessamine, Night-

Jessamine, Orange....2.22

Jessamine, Red Coral..26
Jessamine, Star......23

Jessamine, Star.......23
Juniperus. .........17

Khat................2.

Kumquat.............45

Lagerstromia......2. 29, 30
Lantana.......23, 36,38

Large-leaved Rose Bay 28

Latania ..........9, 11

Laurel, Indtan........14

Laurocerasus.........24

Leadwort, Blue........23

Leather-lcaf Fern........40

Lemon............. 45

Lemon Grass..........20

Lemon Vine.........36

Leonotis...............28

Leptospernum.......28

Ligustrunk......

Lilies, Climbing...

Lily, Barbados.

Lily, Butter:.y

Lily, Climbing...

Lily, Ginger.

Lily, Milk and Wine...4

Lily, Quecn

Lily, Spanish............42

Lily, Spider..........42

Lily, Yellow Day........42

Lime..............45

Limeberry

Lily, Nassau............4

Lily, Natal ..........42

Litchee Fruit .........17
Litchee Nut ....... 17

litchii ........... 17, 47

Lion's Tail..........28
Live Oak...........14

Livistona............... 9

Lomaria...............
Long Moss...........

Lonicera.........25,35

Lycium...............25

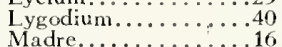

Magnolia..............14

Mahogany, Swamp....16

Manvaviscus..........28

Mandarin....... $17,47,45$

Mangifera......17, 47, 48
Mango.......17, 47,48

Maple, Scarlet........13

Maple, Swamp.........13

Medlar................46

Melaleuca.......... 17,30

Melastoma...........30
Melia.............28

Melon Fruit............28

Mesembryanthemum. 38
Michelia. ........ Page

Milk and Wine Lily...

Monstera.....................

Moreton Bay Fig Tree.14

Morus Bay Fig 1 ree.14

Moses, Bulrush.......2, 20

Moss, Club.

Moss, Gray

Moss, Long....

Moss, Rainbow

Moss, Spanish.

Mulbery.........17,48 4 Poinciana, Dwarf.

Muscadine Grape..... 51

M yrica..............24

Myrtle, Crape............30

Myrtle, Downy .... 23, 51

Myrtle, Cueen Crape..29

Myrtle, Sweet ........28

Myrtlc, Wax..

Nassau Lily

Natal Lily.....

Nephrolcpis. .

Night-blooming

Night-blooming

samine..

Nintooa.

Nolina...............

Oak, Australian Silk...14

Oak, Laurel.........14

Oak, Live.....

Oil Palm.

Oleander.........

Oleaster.............. Colden

Oleaster, Colden-

leaved.

Olcaster, Simon's.......27

(1.........48

Orange Jessamine.......22

Orchard Blueberry. 29, 51

Crchid Canna.

Orcodoxa.

Osmunda, Royal......40

Oxyanthes.........30

Palm, Chinese Fan.... 9

Palm, Fishtail........ 10

PaIm Grass...

PaIm, Oil.

Palm, Pindo...

Palm, Reyal.

Palm, Silver Thatch.

Palm, Sugar.

Palm, Thatch. . .

Palm, Toddy .......

Palmetto, Cuban..

Palmetto, Giant.

Palmetto, Porcupine... 8

Pampas Grass, Silver..20

Pancratium...........42
Pandanus............38

Panicum.

Papaw..

Paper Flower.

Paper Mulberry.

Para Grass..

Passiflora........

Paurotis.....

Pear, Ailligator.

Pecan.................4

Pcreskia...............36

Periwinkle....... $17,48,49$

Persimmons, Japanese 46

Petrea..

$8,9,11$
8.36

Phoenix...
Phrynium.

Phyllanthus.

Phyllaurea.

23,31

Phyllocactus....

Phyllostachys.

Piaropsis.........
Pine, Australian

.38

.19

.43

Pine, Wild.

Pineapple.

Pithecolobium

Pithecoctenium

Plumbaro. .

Plum, Japanese

Plumy Coconut...

Poinsettia.

Poinsettia, White..

Pomelo.

Popinac..

Porana....

Psidium....

Pteris... .

Ptychosperma.

Punica...

Pyrostegie...

Pyrostegra........

Oucreus.

Rainbow Moss.

Raphiolepis. . .

Red Cora I J es

samine..

Red Gum.

Rhapidophyllum.

Rheedia..

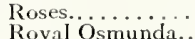

Royal Palm

Royal Poinciana..

Rubber Tree, India.

Rubber Vine......

Rubus.............

Russellia..........

Sabal.

Sago Palm.

Salt Bush

Sansevieria

Sapodilla...

Saraca.

Scarlet Bush.

Scarlet Maple...

Screw Pine.....

Seaforthia ...

Sea-grape.

Page

36

Pittosporum.... 17, 2i, 3

Polypodium..........40

Polypody, Golden..... 40

Polystichum..........40

Porcupine Palmetto....

Potato, Air.........36

Privet, Amoor River...2.

Privet, Japanese......14

Privet, Variegated Ne-

Privet, $W a x \ldots \ldots \ldots \ldots 24$

Queen Crape Myrtle...2

Queen Lily........... 42

Queen's Wreath.......36

Ravenala............38

Red Cattleya Guava...50

Reed, Egyptian Paper.20

Renealmia..........4

Rhodomyrtus .....23,51

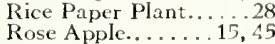

Rose Apple........15, 45

Rose Bay............

leaved ..............28
Rosa de Montana......

Schinus...............

Scott's Compact Bos-
ton Fern...........40 

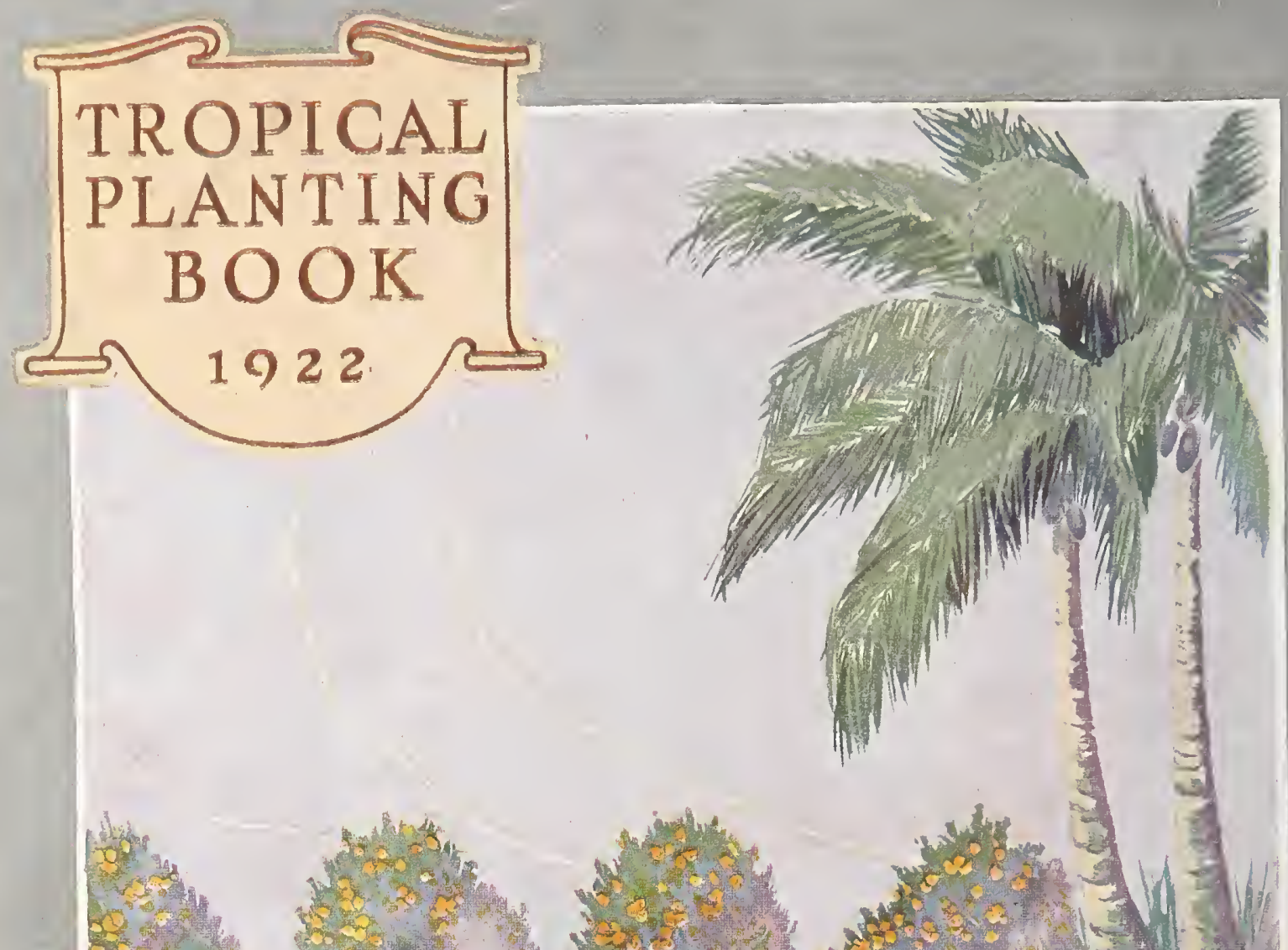